UNIVERSIDADE DE SÃO PAULO

FACULDADE DE FILOSOFIA LETRAS E CIÊNCIAS HUMANAS

DEPARTAMENTO DE HISTÓRIA

PROGRAMA DE PÓS-GRADUAÇÃO EM HISTÓRIA SOCIAL

\title{
Muana Congo, Muana Nzambi Ampungu: \\ Poder e Catolicismo no reino do Congo pós-restauração
}

(1769-1795)

(versão corrigida: original encontra-se no CAPH, FFLCH, USP)

Thiago Clemêncio Sapede

São Paulo 2012 


\section{Muana Congo, Muana Nzambi Ampungu: \\ Poder e Catolicismo no reino do Congo pós-restauração}

$(1769-1795)$

(versão corrigida; original encontra-se no CAPH, FFLCH, USP)

Thiago Clemêncio Sapede

Dissertação apresentada ao programa de pósgraduação em História Social da Faculdade de Filosofia, Letras e Ciências Humanas da Universidade de São Paulo, para a obtenção do título de Mestre em História.

Orientadora: Profa. Dra. Marina de Mello e Souza

São Paulo 2012 


\section{$\underline{\text { Resumo }}$}

O objetivo desta dissertação é debater o lugar e importância dos elementos de origem católica nas práticas políticas no reino do Congo nas ultima quatro décadas do século XVIII. Evitamos lidar com tais elementos através de uma ideia de simples incorporação passiva ou imposição cultural, que seria um equivoco tratando-se da complexidade do processo histórico do reino do Congo. Nosso olhar direciona-se para a agência histórica dos congoleses, sobretudo das elites políticas ligadas ao poder central, assim como local (das "províncias").

O material que a pesquisa analisa são três relatórios redigidos por missionários que habitaram e trabalharam no Congo, em diferentes contextos, durante as quatro ultimas décadas do século XVIII. Além dessas fontes mais consistentes, dispomos de alguns documentos mais fragmentários, principalmente correspondências trocadas entre agentes das missões, autoridades congolesas e autoridades lusitanas em Luanda e no reino de Portugal.

Ao empreendermos o trabalho histórico com as fontes notamos a centralidade dos elementos do cristianismo (africanizados e incorporados no contexto congolês) no funcionamento do complexo sistema político operante no período pós-restauração.

Neste contexto, os sacramentos, insígnias, especialistas, rituais católicos tornamse importantes ferramentas para a rememoração da tradição política do período da centralização, no qual se fundou a vinculação entre catolicismo e o poder político no Congo.

Palavras-chave: História da África, reino do Congo, poder político, catolicismo, missão católica, século XVIII. 


\section{$\underline{\text { Abstract }}$}

The objective of this work is to discuss the importance of the Catholicism in $18^{\text {th }}$ century Kingdom of Kongo political system. We avoid dealing with those elements through an idea of "cultural imposition" or simple incorporation, which would be a mistake when we deal with the complexity of the historical process in Kongo. We focus on the African agency on the historical process, mainly the political elites acting in central or provincial powers.

The research analyzes three reports written by catholic missionaries who lived and worked in Kongo in the last four decades of the $18^{\text {th }}$ century. Besides these (more consistent) sources, we analyze a few other documents: mainly letters exchanged by Congolese authorities, missionaries and Portuguese authorities in Luanda and Lisbon.

In our historical research we note the central importance of the catholic elements (Africanized and incorporated to the Congolese context) to the functioning of the operating political system of the post-restoration period.

Our proposition does not focus on the Catholicism in a context of the missions or the cultural contacts between Europeans and Africans. Beyond that discussion; we choose to look to the Catholic elements as insights to understand the political practices and the solidification of a Congolese political identity.

In this context; the catholic rituals, sacraments, specialists and insignia are seen as important tools of re-memorization of the political tradition that connected Catholicism and political power in the Kingdom of Kongo.

Keywords: African History, Kingdom of Kongo, political power, Catholicism, catholic missions, 18th century 


\section{Sumário}

Agradecimentos: p. 6

Nota sobre ortografia em Kikongo: p. 7

Mapa: Congo e territórios vizinhos no século XVIII: p.8

Introdução: p.9

Capítulo 1: Traduções e Incorporações: uma leitura da historiografia sobre o Congo: p.26

1.1. Trabalhos antropológicos: p.27

1.2. História e cosmologia: p.32

1.3. Similitudes e incorporação: p.36

Capítulo 2: Negócio e Fé: Missão Católica e Tráfico de Escravos: p. 42

2.1. Fragmentação econômica e trafico de escravos: p.43

2.2. Comércio de escravizados na costa congolesa: p. 45

2.3. Interlocutores e intencionalidades nos textos missionários: p.53

2.4. Coroa portuguesa e o financiamento da missão: p.60

2.5. D. José I Nepaxi Giacana e a reconquista de S. Salvador: p.63

2.6. D. Afonso V e a ofensiva diplomática portuguesa: p.70

2.7. O fracasso do projeto comercial português: p.74

Capítulo 3: Catolicismo e Poder Central: p. 88

3.1. Unificação e organização política pós-unificação: p.89

3.2. Quimpanzo e Quinlaza e o debate sobre as makanda: p.91

3.3. D. Afonso I Mvemba a Nzinga e a africanização política do catolicismo: p. 101 
3.4. Títulos nobiliárquicos europeus apropriados: p. 108

3.5. Príncipe e nelumbo: os "reis de fora": p. 112

3.6. Mani Vunda e os espíritos locais: p.115

3.7. A Mbanza de S. Salvador e legitimidade Política do Mani Congo: p.122

3.8. Cavaleiros da Ordem de Cristo e a legitimidade do Mani Congo: p.130

3.9. Missionários e o Mani Congo: negociação, conflito e dependência: p.135

Capítulo 4: Catolicismo e Poderes Locais: $p 146$

4.1. Mucondo e Mpemba: as terras da rainha: p. 150

4.2. Grão ducado de Mbamba: p.152

4.3. Quibango: p.156

4.4. Mbula dia Lemba e Nsundi: p.158

4.5. Oando: p. 160

4.6. Soyo, Mossul e Ambuíla: p.162

4.7. O sacramento do matrimónio e as elites locais: p.175

4.8. Nlekes, Intérpretes e Mestres: os especialistas rituais locais: p.182

4.9. Escrita, língua portuguesa e poder político: p.192

Considerações finais: p. 199

Bibliografia Geral: p. 204 


\section{$\underline{\text { Agradecimentos }}$}

Gostaria de agradecer à Fundação de Amparo à Pesquisa do Estado de São Paulo pela concessão da bolsa de financiamento para esta pesquisa.

À Profa. Marina de Mello e Souza, pela orientação deste trabalho, tendo sido sempre solícita, desde as primeiras conversas (ainda na graduação) até as revisões finais da dissertação. Sua generosidade e dedicação na orientação desta pesquisa foram fatores decisivos para seus resultados.

À profa. Maria Cristina Wissenbach, pela participação no exame de qualificação e pela enriquecedora e generosa interlocução em diversas outras ocasiões. Ao prof. Carlos Zeron, pela participação no exame de qualificação e por ter sido uma importante referência no que diz respeito ao rigor metodológico no trato com as fontes históricas.

Aos muitos pesquisadores africanistas com os quais tive o privilégio do diálogo em eventos e encontros acadêmicos: Prof. Joseph Miller, Profa. Lucilene Reginaldo, Prof. Jean-Michel Mabeko-Tali, Profa. Cecile Fromont, Profa. Vanicéia Silva Santos, Prof. Alexandre Vieira Ribeiro, Prof. Alexsander Gebara, Lia Laranjeira, Juliana Ribeiro, Rosana Gonçalves, Alexandre Marcussi, Mariana Fonseca, dentre outros.

Aos colegas do Núcleo de Estudos de África, Colonialidade e Cultura Política e Revista Sankofa: Muryatan Barbosa, Eduardo Januário, Irinéia Franco, Flavio Francisco, Rodrigo Bonciani e Maria Rosa Ribeiro. Ao grande amigo e insigne medievalista germânico Marcus Baccega.

Aos colegas e queridos amigos com quem trabalhei no Museu Afro Brasil, com quem aprendi, dentre muitas coisas, a importância da educação, dos estudos africanos e afro-brasileiros no combate cotidiano às injustiças sob as quais este país foi fundado.

Aos meus pais: Fábio e Carmen, pelo apoio irrestrito e incondicional em todas as etapas de minha formação. À Nira, minha companheira, por toda a compreensão, amor e o suporte no plano de minha vida pessoal.

Por ultimo (last but not least), gostaria de agradecer imensamente ao Prof. John Thornton pela concessão das cópias das fontes históricas utilizada neste trabalho; por ter me aceito como aluno na Universidade de Boston em 2008, ocasião na qual nasceu este projeto; e pelo grande privilégio da interlocução desde então. Sem a enorme generosidade do Prof. Thornton este trabalho não teria sido possível. 


\section{Nota sobre ortografia em Kikongo}

Optamos pelo "aportuguesamento" da grafia do kikongo, em detrimento do uso da grafia do kikongo moderno. Reproduzimos essencialmente a forma com as quais os termos foram registrados pelas fontes de época, adaptando para o português atual em alguns casos. Desta forma, o leitor nativo em português estará mais próximo foneticamente da pronúncia do kikongo. Seguimos, portanto a indicação do pioneiro africanista brasileiro Alberto da Costa e Silva.

Utilizamos, por exemplo, no título da dissertação: "Muana Congo. Muana Nzambi Ampungo" 1 ao invés de "Mwana Kongo, Mwana Nzambi Mpungo". Assim como "Mani Congo", frente a "Mwene Kongo" ou "Ambuíla" ao invés de "Mbuwila".

Estamos conscientes de que esta opção coloca-nos em desacordo com a convenção da tradição historiográfica sobre o reino do Congo (majoritariamente norteamericana) e mesmo da escrita moderna do kikongo em Angola. Apesar desta considerável desvantagem, os benefícios em aproximar o leitor lusófono (não familiarizado com o kikongo) da fonética africana parecem-nos justificar a escolha.

\footnotetext{
${ }^{1}$ A palavra kikongo "muana" (mwana) significa "criança" ou "filho". As fontes do século XVIII nos informam do uso do título "muana Congo" exclusivamente por membros das altas elites congolesas (chamados também de "infantes"), que seriam descendentes diretos do grande rei D. Afonso I Mvemba a Nzinga. No século XVIII (período pós-restauração) apenas os muana Congo poderiam ser eleitos reis ou chefes de províncias. "muana Nzambi Ampungo" significa literalmente "filho de Deus", termo utilizado nas missões pelos padres europeus para se referirem a Jesus Cristo. Frei Rafael questionava-os perguntando se acreditavam em "muana Nzambi Ampungo" e eles respondiam positivamente para que se prosseguisse a administração dos sacramentos. Por isso, neste título "Muana Congo, Muana Nzambi Ampungo" pretendemos apresentar um jogo de palavras em kikongo que traduz a filiação pelas elites a uma tradição política que vincula poder e cristianismo.
} 


\section{Mapa: Congo e territórios vizinhos no século XVIII}

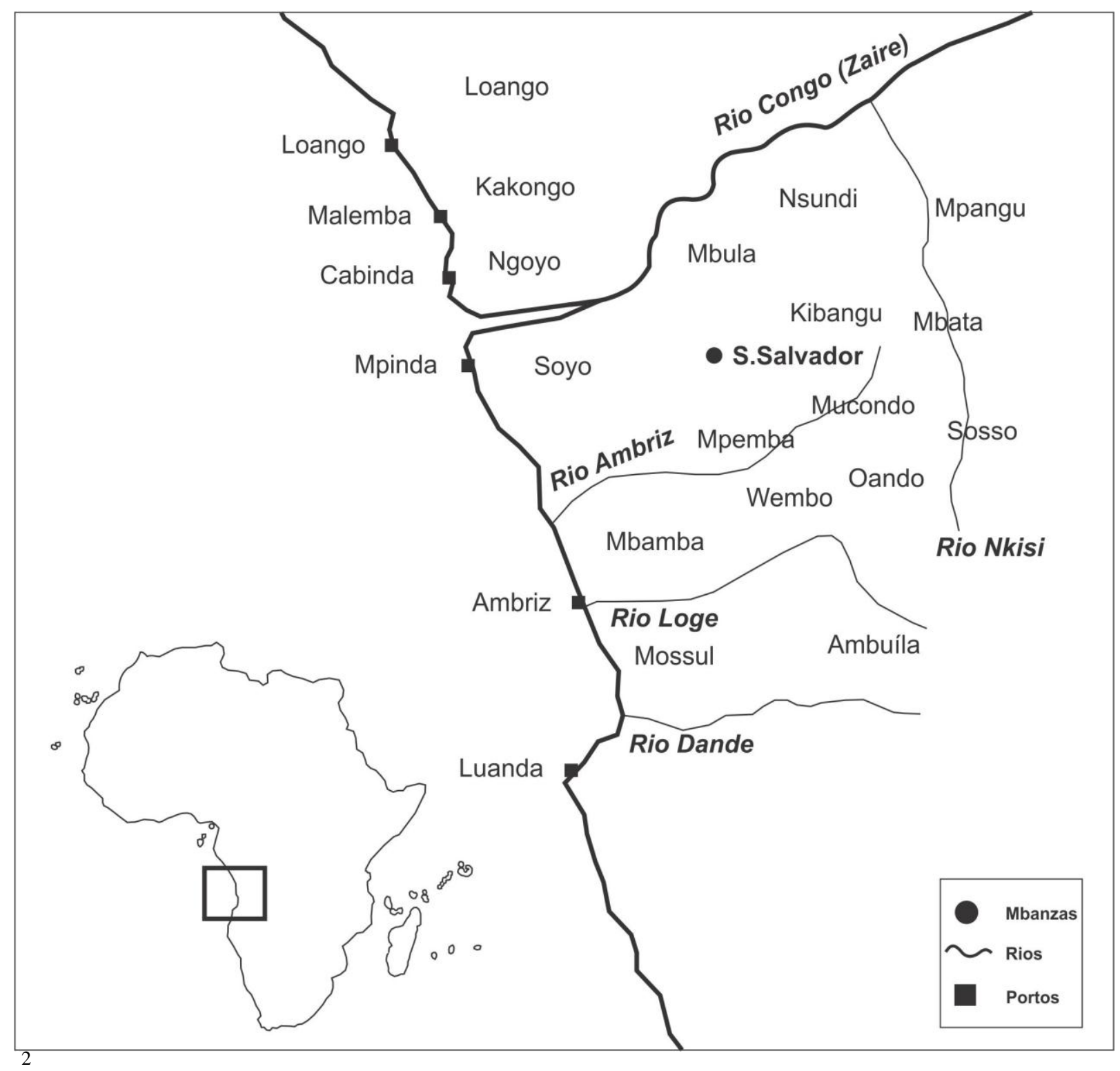

${ }^{2}$ Desenhamos este mapa com base nas informações territoriais oferecidas por Cherubino da Savona e Frei Rafael Castelo de Vide: Frei Rafael Castello de vide: Viagem e missão no Congo. Academia das Ciências de Lisboa, MS Vermelho 296. Toso, Carlo. Relazioni inedite di P.Cherubino Cassinis da Savona sul Regno del Congo e sue Missioni. In L'Italia Francescana. 1975, p. 135-214. Agradeço imensamente ao Prof. Thornton pela concessão destas fontes. Utilizei também mapas dos séculos XVIII e XIX apresentado por Suzan Herlin Broadhead: Broadhead, Susan H. Trade and Politics on the Congo coast. 1790-1890. Boston University. 197, p.240, 241. E por John Thornton para perído o Congo do século XVII: Thornton, John K. Kingdom of Kongo. Civil war and Transition 1641-1718. Madson, Wisconsin Press, 1983. p. 105. The Kongolese Saint Anthony. Dona Beatriz Kimpa Vita and the Anthonian moviment, 1984-1706. Cambrigde, Cambridge Univ. Press, 1998, p. 11. 


\section{Introdução}

Lukeni lua Nimi (Nimi a Lukeni) nasceu entre 1401 e 1424 em Vungo (Bungo), território ao norte do rio Zaire, filho de Nimi a Zima, soberano deste potentado. Apesar de suas qualidades para administrar o território, Lukeni não era o legítimo herdeiro ao cargo de chefe político ocupado por seu pai, sendo apenas o quarto irmão na sucessão do poder. Lukeni decidiu cobrar impostos em nome de seu pai, de sua própria mãe grávida, que se recusou a pagá-los (provavelmente diante de sua ilegitimidade como sucessor político). Diante da recusa, Lukeni esfaqueou seu ventre, assassinando mutuamente sua mãe e o irmão em gestação. Este gesto marcou a ruptura de Lukeni com a tradição política vigente. Em seguida, ele migrou em direção ao sul e após cruzar o grande rio Zaire, subjugou os povos agricultores que ali viviam, fundando assim um novo estado, chamado Congo. A partir desta fundação, Lukeni passou a expandir seu território dominando pequenas chefaturas, através de um sistema de poder altamente centralizado sediado na capital intitulada Mbanza Congo (Cidade do Congo). ${ }^{3}$ Ao tornar-se soberano deste novo estado, Lukeni teria passado a ser chamado de "ntinu", inaugurando este novo título, o mais alto título político do então recém-fundado Congo. A partir de então, apenas os descendentes de Lukeni poderiam ocupar o cargo de chefe político do Congo (Mani Congo) e gozar deste título: ntinu. ${ }^{4}$

Esta narrativa de fundação mítica do "reino" do Congo foi coletada (apresentando diferenças em cada versão) pelos missionários Mateus Cardoso e Giovanni Cavazzi de Montecucculo em meados do século XVII e exposta pelo historiador John Thornton em trabalhos sobre as origens do reino do Congo. ${ }^{6}$

\footnotetext{
3 Thornton, John K. Origin traditions and history in Central Africa. African Arts. V. 34. Los Angeles, UCLA African Studies Center, 2004.p 32.

${ }^{4}$ Thornton, John K. The origins and early History of the Kingdom of Kongo, 1350-1550. International Journal of African Historical Studies, V34, No. 1. Cambridge University Press, 2001, p.69-83

5 O termo "reino" aparece na documentação desde finais do século XV, também em toda historiografia sobre o Congo. Justifica-se pela semelhança na complexidade e hierarquia da organização política aos reinos europeus, semelhança suficiente para que se use a mesma terminologia. O mesmo ocorre para diversos outros "estados" centro-africanos. Além disso, no caso do Congo, o título "rei" passou de fato a ser uma marca dos soberanos dentro de um sistema de renovação política marcada por novos títulos, como mostraremos no terceiro capítulo.

6Thornton apontou para o caráter altamente "ideológico" desta tradição, chamando atenção pa ra algumas incoerências das informações fornecidas por esta tradição. Ele levanta a hipótese do verdadeiro fundador do Congo ter sido Nimi a Zima, o que faria de Lukeni o segundo rei ${ }^{6}$ do Congo. De qualquer forma, Thornton acredita ter havido uma ruptura na tradição política que fez com que Lukeni tenha inaugurado o
} 
Nas ultimas décadas do século XVIII, mais de um século após a presença de Cavazzi e Cardoso, os missionários Rafael de Vide e Raimundo Dicomano registraram uma tradição semelhante. Porém, desta vez, o personagem não era Lukeni lua Nimi e sim Mvemba a Nzinga e ao invés da fundação do Congo tratava-se da "conversão" das elites governantes ao cristianismo em décadas finais do século XV.

Antes de apresentarmos a narrativa do século XVIII sobre a "cristianização" das elites congolesas, é importante expormos os eventos destes primeiros contatos a partir dos trabalhos historiográficos que se debruçaram diretamente sobre o período e sobre as fontes da passagem do século XV ao XVI, período dos primeiros contatos das elites do Congo com portugueses.

Após esta apresentação, observaremos a maneira com que o evento da incorporação do catolicismo foi reinventado nas fontes selecionadas para esta pesquisa, três séculos mais tarde.

Quando era o jovem chefe da província de Nsundi, Mvemba a Nzinga recebeu ao lado de seu pai Nzinga a Kuwu uma comitiva de exploradores portugueses liderados por Rui de Souza na capital Mbanza Congo. Estes homens de pele branca, que chegaram pelo mar vindos de um território longínquo, falavam em (língua inicialmente incompreensível) em nome de seu soberano (que possuía o título de "rei"), dizendo-se interessados em estabelecer parceria com o ntinu africano. Esta parceria entre rei e ntinu ofereceria aos membros da alta elite política congolesa de então o acesso a um inédito repertório ritual e material advindo do distante reino de Portugal. ${ }^{7}$ Antes mesmo da recepção dos portugueses em Mbanza Congo, alguns congoleses estiveram em Lisboa e retornaram no ano de 1485 testemunhando o grande poder do chefe europeu e aprendendo sua língua e costumes religiosos. Foram, portanto, importantes intermediadores dos primeiros contatos. ${ }^{8}$

título de "ntinu". Todos esses ntinu possuíam também o título de "Mani Congo", que possuía significado mais genérico de "soberano do Congo". Portanto, pela recuperação histórica de Thornton Luken i poderia ser o segundo Mani Congo, mas certamente foi o primeiro ntinu, e é a este título que confere a ele o papel de fundador mítico.

Thornton, John K: The origins and early History of the Kingdom of Kongo, p.69-83 e Origin traditions and history in Central Africa, p.22-39.

${ }^{7}$ Hilton, Anne. The kingdom of Kongo. Oxford, Oxfrord, Oxford University Press, 1985, p.50-69.

8Macgaffey, Wyatt. Dialogues of the deaf: Europeans on the Atlantic coast of Africa. In: Schwatz, S. Implicit Understandings. Observing, reporting, and reflecting on the encounters between Europeans and other peoples in the Early modern era. Cambridge, Cambridge Univ.Press, 1996. Esse artigo de 
O acesso aos novos e poderosos elementos dever-se-ia dar por ngangas ${ }^{9}$ europeus especializados nestes cultos através do rito iniciáticos, chamado pelos mesmos de "batismo". Nzinga a Kuwu e seu filho Mvemba a Nzinga (assim como outros seletos membros da alta elite), depois de submetidos ao ritual, ganharam direito de acesso aos novos elementos mágico-religiosos, assim como diferentes produtos desconhecidos que vinham do longínquo território. Como marca deste privilégio e desta parceria, os dois (dentre alguns poucos privilegiados) receberam novos nomes. Nzinga a Kuwu ganhou o nome de D. João (assim como o soberano português) e o jovem Mvemba a Nzinga foi nomeado D. Afonso.

D. Afonso se dedicou em conhecer e difundir o repertório originário do cristianismo europeu desde sua iniciação pelo batismo. Além disso, aprendeu a língua dos portugueses, e fez do uso dela uma importante ferramenta para consolidação desta parceria e também para a comunicação com o soberano, rei de Portugal, assim como com a autoridade máxima no contexto destes novos rituais: o papa. Por isso, dispomos de fontes escritas por este personagem descrevendo os conflitos internos pela sucessão do título de ntinu e a posição de Mani Congo. ${ }^{10}$

Nestes, Mvemba a Nzinga descreve, por sua própria pena, a batalha que travou contra seu irmão pela sucessão do poder central no Congo. Os partidários de seu irmão Mpanzo a Kitima eram, segundo Afonso, muito numerosos e bem armados. Enquanto ele dispunha apenas de trinta e seis soldados. A derrota de D. Afonso I parecia certa, não fosse o fato deste candidato a ntinu dispor do novo repertório ritual e religioso apresentado pelos lusitanos, vejamos sua descrição:

\footnotetext{
MacGaffey traduz bem sua concepção de cristianismo, mas não é o primeiro, ideias semelhantes foram formuladas em trabalhos anteriores já citados.

${ }^{9} \mathrm{Nganga}$ é termo em kikongo (e em diversas outras línguas bantu) que define "curandeiros" ou "médicos": homens ou mulheres que manipulam forças do outro mundo (e elementos naturais como ervas) para curar pess oas ou reestabelecer o equilíbrio social. Ao contrário dos ndoki ("feiticeiros") que manipulavam forças mágicas exclusivamente para vantagem própria ou de um cliente, gerando desequilíbrio para a sociedade. Os padres europeus foram identificados como ngang a desde os primeiros contatos. Ver: Thornton J. K. The development of an African Catholic Church in the Kingdom of Kongo, 1491-1750. The journal of African History. Cambridge, Cambridge University Press, 1985, p.158, 159.
}

10 Thornton J. K. The development of an african Catholic Church in the Kingdom of Kongo, 1491-1750. The journal of African History. Cambridge, Cambridge University Press, 1985, p. 150-165. 
(...)começámos a pelejar com os nossos contrários e dizendo os nossos trinta e seis homens inspirados da graça e ajuda de Deus, já fogem, já fogem os nossos contrários se puzeram em desbarato, e foi por eles testemunhado, que viram no ar uma Cruz branca, e bem aventurado Apóstolo Sant Tago com muitos cavalos armados e vestidos de vestiduras brancas pelejar, matar neles, e foi tão grande o desbarato e mortandade, que foi coisa de grande maravilha. ${ }^{11}$

Notamos que o acesso recente aos elementos do catolicismo (a cruz e o santo guerreiro) constitui-se, no relato, como a principal ferramenta desta mítica vitória que possibilitou a consolidação de D. Afonso I no poder. Os novos elementos mágicoreligiosos, assim como as novas técnicas (como a escrita) e a parceria com os poderosos chefes europeus (rei de Portugal e papa) tornam-se os principais argumentos para a legitimidade de D. Afonso I frente ao seu irmão.

Após a vitória de Afonso seguiu-se um período de intrínseca relação entre a religião católica e o poder central no reino do Congo. O longo reinado de Afonso I e as inovações políticas e religiosas realizadas pelo soberano fizeram com que seus sucessores continuassem a política de propagação dos novos ritos, insígnias, deidades, dentre outros elementos de origem europeia. Estes elementos do catolicismo tornaramse, gradativamente (sobretudo durante o reinado de Mvemba a Nzinga) vinculados ao poder do Mani Congo, que até meados do século XVII gozou de controle sobre os Mani locais. O incentivo da presença de missionários europeus foi estratégia importante das elites congolesas (principalmente as elites ligadas ao rei). A Companhia de Jesus, em franco crescimento, junto à expansão marítima ibérica, ofereceu grande número de padres durante o século XVI. Estes religiosos foram importantes na constituição de escolas de gramática e na catequese das elites congolesas. Juntamente com intérpretes e mestres congoleses, muitos deles formados em Portugal, difundiram a língua portuguesa e os preceitos cristãos dentre as elites, formando também em Mbanza Congo, mestres e intérpretes congoleses. ${ }^{12}$

\footnotetext{
${ }^{11}$ Ferronha, António Luís Alves (org). Cartas de D. Afonso Rei do Congo. Lisboa, Comissão pela comemoração dos descobrimentos portugueses, 2000, p.21.

12Thornton, John. The development of an African Catholic Church in the Kingdom of Kongo, p.166.
} 
$\mathrm{Na}$ batalha sucessória contra seu irmão, D. Afonso I consolidou a si e a sua descendência no poder. $\mathrm{O}$ catolicismo tornou-se argumento para realizar a ruptura com a tradição que questionava sua legitimidade como ntinu. Por isso, fomentar as práticas católicas no Congo tornou-se uma estratégia de D. Afonso e seus sucessores para reafirmar cotidianamente a nova tradição e rememorar a sua fundação. ${ }^{13}$

A importância do catolicismo associado à fundação de uma nova tradição política aparece também na versão da batalha entre D. Afonso I e Mpanzo a Kitima registrada por Frei Rafael de Vide e Frei Raimundo Dicomano nas ultimas décadas do século XVIII, quase três séculos após o evento:

(...)houve também neste Reino no princípio uma coisa memorável, de que há tradição, virem os anjos em defesa do Rei, em uma guerra que the faziam seus inimigos, aparecendo no ar cinco braços, que em um instante mataram todos seus inimigos, (...)O motivo da guerra foi porque o Rei então chamado D. Afonso mandou enterrar viva a sua própria mãe, por não querer abraçar a fé Católica, e os parentes vinham por isto fazer guerra ao Rei; pelo que todos morreram. ${ }^{14}$

As diferenças mais significativas entre esta versão e a do século XVI (divulgada pelo próprio Mani Congo) dizem respeito ao motivo do confronto. $\mathrm{Na}$ narrativa do século XVIII, o assassinato da mãe (motivados pela recusa desta em abraçar a fé católica) cometido pelo próprio D. Afonso aparece no relato e torna-se o motivador da rivalidade do jovem rei com "os seus parentes".

Ora, nesta versão da narrativa de "conversão" notamos padrões significativos em relação à narrativa mítica na qual Lukeni dia Nimi fundou o reino do Congo, recolhida por Cavazzi e Mateus Cardoso no século XVII, citada há pouco.

Em ambas as narrativas, Lukeni e Afonso eram filhos de chefes políticos e desejaram herdar o poder dos pais, mas em ambos os casos foram impedidos pelo sistema tradicional de sucessão ("seus parentes"). Considerados ilegítimos pela tradição

\footnotetext{
13 Thornton, John K: The origins and early History of the Kingdom of Kongo, p.69-83.

${ }^{14}$ Frei Rafael Castello de vide. Viagem e missão no Congo, p. 39-41.
} 
política vigente, ambos optam por rompê-la. O assassinato das mães (e dos irmãos) nas duas narrativas parece simbolizar esta ruptura. É importante lembrar de que a transmissão da linhagem se dava de forma matrilinear no Congo, portanto, o assassinato da mãe simbolizaria a fundação de uma nova "linhagem", uma nova tradição. Desta forma, segundo a simbologia presente nas narrativas, ambos os personagens romperam com a ancestralidade tornando-se fundadores de novas tradições políticas, nas quais passam a figurar como ancestrais "míticos". Incorporou-se, como consequência, em ambos os casos novos títulos políticos: Lukeni tornou-se ntinu; Afonso tornou-se rei.

Para a mentalidade política do século XVIII, os elementos do catolicismo ${ }^{15}$ aparecem como justificadores da ruptura com a tradição vigente e de uma fundação (ou refundação) do reino do Congo por D. Afonso I nos mesmos moldes de Lukeni. D. Afonso tornou-se, neste período, o principal referencial para um sistema baseado numa tradição de outrora.

Observaremos o funcionamento deste sistema, ao longo da dissertação e debateremos os sentidos "africanizados" que o catolicismo recebeu no contexto pósrestauração.

\section{Congo pós-restauração: Pesquisas e Fontes:}

Antes de nos debruçarmos sobre as fontes em busca da compreensão do papel que os elementos católicos exerciam no contexto congolês, trabalho que será realizado a partir do segundo capítulo, é importante que façamos uma exposição sobre as transformações históricas que foram significativas e uma contextualização do século XVIII através dos autores que escreveram sobre o tema.

A relativa escassez de fontes do período também reflete na quase ausência de trabalhos historiográficos específicos sobre o século XVIII. Os principais especialistas no Congo pesquisaram os séculos XVI e XVII, nos quais a missão católica foi constante nos legando muitos documentos escritos. O período após a batalha de Ambuila em 1665, evento que marcou o declínio das atividades missionárias, foi tratado de maneira

\footnotetext{
${ }^{15}$ Por "elementos católicos" ou "do catolicismo" entendemos: conjunto de sacramentos, insígnias, rituais, além dos templos e o próprio clero oriundos originalmente do catolicismo e apresentado aos congoleses por europeus durante os primeiros séculos de contato.
} 
mais indicativa. Pelo fato da maioria dos autores terem se preocupado com o período apenas superficialmente não puderam - devido às suas opções de recorte temporal explorar toda a potencialidade das fontes históricas, tampouco buscar novos documentos. Por isso, acreditamos que muitas dessas interpretações são frágeis e devem ser utilizadas com cuidado. Daí provém nossa opção de expor cada autor no contexto de sua obra, sem adotarmos uma ou outra interpretação a priori. Nossas ideias mais gerais sobre o período serão expostas mais tarde, nas considerações finais desta dissertação, e são fruto do trabalho com as fontes que realizamos no percurso da pesquisa.

Há uma ideia comum entre as interpretações dos estudiosos do Congo, que nos interessa aqui: todos eles concordam que o século XVIII foi um período muito particular na história política congolesa frente aos anteriores. Isso se deu em consequência das significativas transformações que, para eles, ocorreram desde $1665 .{ }^{16}$

Frei Cherubino da Savona, na primeira página do relatório de sua missão, escrito em meados do século XVIII diz: “O Reino do Congo, por melhor dizer Império, por que tem vários diferentes reinos e muitíssimas províncias, principados, ducados. Está na etiópia meridional e é quase todo católico". ${ }^{17}$

Outro missionário, Rafael Castelo de Vide, uma década depois fez uma avaliação semelhante:

Há este Reino muito antigo, dilatado, e hum grande Imperio, ainda que hoje se ache dividido entre muitos grandes levantados, que se separaao

\footnotetext{
${ }^{16}$ Autores que não trabalharam especificamente o período, mas levantaram possibilidades quanto ao século XVIII foram Balandier, Vansina, Hilton e Thornton. Balandier, G. Daily life in the Kingdom of Kongo. New York. Meridian books. 1969. Vansina, Jan. Kingdoms of the Savana. Winsconsin University Press. 1966. Thornton, John K. The Kingdom of Kongo. 1983.

${ }^{16}$ Thornton, John K. The origins and early History of the Kingdom of Kongo, 1350-1550". International Journal of African Historical Studies, VoL 34, Cambridge University Press. 2001.

${ }^{17}$ Tradução livre: Il Regno del Congo, o per meglio dire l'Imperio, perche tiene alcuni diversi Regni soggetti, e moltissime Provincie, Principati, Ducati, stà nell Etiopia meridional e, e quasi tutto cattolico." Toso, Carlo. Relazioni inedite di P.Cherubino Cassinis da Savona sul Regno del Congo e sue Missioni, p. 207.
} 
do Rey, mas sempre se reconhecem seus vassallos, e sugeitos; em a maior parte delle se abraca a fe Catholica. ${ }^{18}$

O termo "Império" foi também utilizado, com base em Savona, pela historiografia. O historiador Jan Vansina foi o primeiro a fazê-lo. Ele foi um dos pioneiros nos estudos históricos das sociedades da África central, dentre eles o reino do Congo. A baliza cronológica do capítulo sobre o Congo do importante livro "The Kingdoms of the Savana” chega até meados do século XVII. Mas como parte de um capítulo final sobre tráfico de escravos no século XVIII, o autor indica as principais mudanças que a sociedade congolesa teria sofrido, influenciada pelo comércio escravista. ${ }^{19}$ A opção de associar a história congolesa após 1700 ao contexto de uma história do tráfico de escravos, descolando-a dos períodos anteriores, foi comum entre os autores. Explica-se em parte pela ausência de fontes sobre o período que não sejam associadas ao comércio de escravizados, e pelo fato desta atividade ter atingido seu apogeu justamente no século XVIII. ${ }^{20}$

Segundo Vansina, o poder político e econômico teria passado por uma intensa fragmentação em diversos níveis da hierarquia congolesa e o principal agente dessa transformação foi, para ele, o tráfico de escravos. Com o enfraquecimento da capital S. Salvador as elites locais teriam assumido o controle sobre pequenas rotas comerciais, o que fragmentou o sistema de captura e venda de escravos para mercadores europeus no litoral do Congo. Para o historiador, o fator econômico foi determinante para a emancipação política das províncias. Apesar da fragmentação e da perda de controle do rei do Congo sobre as rotas, ainda restou no Congo do século XVIII a unidade cultural e simbólica do antigo reino. Para Vansina, os padrões de organização podem ser comparados ao Império Romano. ${ }^{21}$

Mesmo tendo lançado um olhar bastante geral sobre o século XVIII, Vansina ofereceu uma contribuição importantíssima, pois se opôs às interpretações de estudiosos anteriores, como: Van Wing, Jean Cuvelier, Balandier e Randles. Estes interpretaram

\footnotetext{
18 Frei Rafael Castello de vide. Viagem e missão no Congo.p. 26.

${ }^{19}$ Vansina, Jan. Kingdoms of the Savana.. 1966.

${ }^{20}$ Alencastro, Luis Felipe de. O Trato dos Viventes: formação do Brasil no Atlântico Sul, séculos XVI e XVII. São Paulo. Cia das Letras. 2000.

21 No original utilizou o termo "Holly Roman Empire". Vansina, Jan. Kingdoms of the Savana. Winsconsin Univ Press. 1966. P. 189-197.
} 
todo o período após a guerra de Ambuila em 1665, na lógica de uma crise irreversível rumo ao colapso das instituições congolesas em meados do século XIX. Esses autores apresentavam uma visão proto-colonial sobre o período, enxergando os agentes europeus como principais responsáveis pela decadência congolesa. ${ }^{22}$ Vansina foi o primeiro a romper com esta interpretação, oferecendo um viés mais interno dos processos históricos, mesmo tendo levado em conta o comércio atlântico como vetor significativo de transformações. Ele enfatizou que a fragmentação ocorrida entre 1665 e 1710 foi o mais importante fato da história do Congo, período no qual ocorreu a transformação radical de sua estrutura.

Este processo que quase levou ao colapso das instituições políticas congolesas gestou um sistema inteiramente novo e fragmentado, no qual o poder econômico do rei sobre a venda de escravos foi em parte transferido para as elites locais. Havia também, segundo ele, um sistema determinante de escravidão doméstica no qual o poder de um homem era traduzido no número de escravos que ele possuía, esquema muitíssimo interessante que infelizmente é citado sem ser aprofundado pelo autor. Vansina não fala da importância do catolicismo nesse contexto. Em seu capítulo sobre o Congo no mesmo livro argumentou que os elementos católicos não exerceram papel significativo após o século XVII. ${ }^{23}$

A historiadora norte-americana Susan Broadhead ofereceu uma interpretação semelhante à de Vansina, e dialoga com ele sem explicitar discordâncias. ${ }^{24}$ Percebemos, porém, algumas diferenças significativas na interpretação desta historiadora, que afirma ter existido no Congo, durante os séculos XVIII e XIX, uma tendência à fragmentação que chama de "kongo syndrome" ${ }^{25}$, ocorrendo em todas as esferas da organização política: desde o rei até as aldeias. A autora acredita, porém, que os novos poderes econômicos continuaram vinculados à tradição político-social de períodos anteriores.

\footnotetext{
${ }^{22}$ Os principais autores a divulgar essa interpretação são: Van Wing, Joseph: Études Bakongo. Bruxelas, 1921; Cuvelier, Jean: L'Ancién Royaume de Congo, Bruxelas, 1946 e Randles, W.G.L. L'Ancién royaume du Congo . Paris, 1968.

${ }^{23}$ Vansina, Jan. Kingdoms of the Savana. Winsconsin Univ Press. 1966, p.37-70.

24 Broadhead, Susan H. Trade and Politics on the Congo coast, p. 53-60. A mesma autora publicou um artigo que sintetiza as mesmas idéias da tese, acrescentando algumas fontes: Beyond Decline: The Kingdom of the Kongo in the Eighteenth and Nineteenth Centuries. The International Journal of African Historical Studies. Vol. 12. Boston University African Studies Center. p. 615- 650.
}

\footnotetext{
${ }^{25}$ Julguei essa definição intraduzível. A própria autora a define como uma "tendência à fragmentação".
} 
A reorganização, em Broadhead, não foi tão profunda como em Vansina, pois, para a autora, ocorreu com base em estruturas tradicionais, como as linhagens, mantenedoras de certa coesão política.

A novidade mais significativa do trabalho de Broadhead foi chamar a atenção para a importância dos elementos cristãos, tanto na fragmentação quanto na manutenção de uma identidade política comum aos congoleses de diferentes províncias. Esses elementos seriam essenciais tanto para a ritualização do poder das elites locais ascendentes como para a manutenção do "mito vivo", que teria se tornado o rei do Congo, juntamente com outros símbolos do poder central que remeteriam ao rei Afonso I. As insígnias e sacramentos cristãos não seriam mais de domínio apenas do rei, mas, agora, também de novos membros das elites locais, que eram legitimados e ligados à tradição simbólica do poder centralizado através de títulos como "fidalgo" ou "cavaleiro da ordem de cristo". Além disso, a ritualização cotidiana desse poder de "novos ricos" ligados ao tráfico se dava através dos sacramentos católicos como o casamento, a comunhão e as próprias missas. Por isso dependiam da constante presença de missionários. Para Broadhead, esse acesso privilegiado aos sacramentos os diferenciava dos estratos populares, que tinham sua relação com o cristianismo restrita ao batismo.

O termo "Império" também foi discutido por John Thornton, para definir a organização política do século XVIII em seu trabalho "The Kingdom of Kongo", mesmo que seu recorte temporal não chegasse até o período. O autor apresenta algumas divergências dos trabalhos citados anteriormente no que diz respeito à importância do cristianismo e ao peso do tráfico de escravos no processo de fragmentação e restauração. ${ }^{26}$ Primeiramente, quanto ao comércio de escravos, Thornton não o vê como fator significativo de desintegração, pois privilegia um olhar para as transformações internas ao Congo, representando a oposição mais radical aos estudiosos da "situation coloniale" já $\operatorname{citados}^{27}$. Segundo esse autor, os fatores essenciais nesse processo de transformações foram as disputas políticas internas ao reino, enxergando a influência europeia como secundária. Nesse livro o autor vê a restauração, sob o Mani Congo Pedro IV Nessamo a Mbandu em 1709, como evento que teve atributos principalmente

\footnotetext{
${ }^{26}$ Thornton, John K. Kingdom of Kongo. Utilizei principalmente o capítulo oitavo p. 110-130 e o epílogo, que demonstram as ideias do autor sobre o século XVIII.

${ }^{27}$ Os principais autores a divulgarem essa interpretação são Joseph Van Wing: Études Bakongo. Bruxelas, 1921; Jean Cuvelier: L'Ancién Royaume de Congo. Bruxelas, 1946 e Randles: L'Ancién royaume du Congo . Paris, 1968.
} 
simbólicos e identitários, na medida que a autonomia política e econômica das províncias em relação ao rei não impedia que seus moradores se declarassem ainda pertencentes ao reino. Para Thornton, aquilo que chama de "cristianismo congolês" ou "cristianismo crioulo" foi importante sustentáculo da identidade política congolesa.

O recente trabalho do historiador Elikia M’Bokolo também tratou do período do século XVIII no Congo por um viés do tráfico de escravos, mas com um olhar que privilegiou o processo interno, mesclando criticamente interpretações de Vansina e Thornton. $\mathrm{O}$ autor segue, também, uma linha semelhante à de Broadhead, aprofundando alguns termos trabalhados pela autora. Segundo o autor, durante o período de fragmentação, o poder político e a identidade congolesa teriam sido baseados em três instituições distintas: kinfumo, escravismo e catolicismo.

$\mathrm{Na}$ esfera kinfumo residiriam todos os elementos e símbolos ligados ao poder central "tradicional" no Congo. O próprio soberano, a capital São Salvador, os títulos oferecidos pelo rei, dentre outras insígnias. Esta esfera seria a estruturadora do poder simbólico do Mani Congo, mesmo que na prática a região da capital não passasse de "um reino entre vários outros" no ponto de vista da autonomia política. ${ }^{28}$

O escravismo seria, como em Broadhead e Vansina, regulado pelas elites provinciais das mbanzas e "novos ricos" que teriam aproveitado a situação de desestruturação do poder tradicional para assumir controle sobre fatias significativas do comércio de escravos com holandeses, franceses e ingleses na costa.

O catolicismo, tema de principal interesse nessa pesquisa, foi apresentado por M'Bokolo com significados diferentes para classes "populares" e para as elites. Os congoleses pertencentes às classes populares teriam elementos católicos como parte importante de sua religiosidade cotidiana, mas esse "catolicismo" era pouquíssimo europeu, uma vez que fora incorporado aos cultos tradicionais. Um exemplo dado foi o culto aos santos, que teria sido integrado na esfera do culto aos mortos. ${ }^{29}$ Para as elites políticas e econômicas do Congo, por sua vez, aquilo que M’Bokolo chama de

\footnotetext{
${ }^{28}$ M'Bokolo, África Negra: História e Civilizações. Tomo I. Até o século XVIII. Edufba/ Casa das Áfricas, 2009. p. 413-440.

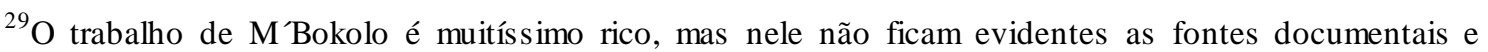
historiográficas das quais ele retira as informações. Em relação à ideia do catolicismo circunscrito no culto aos mortos no imaginário popular provavelmente apoiou-se num dos trabalhos do antropólogo Wyatt MacGaffey, ou no trabalho de Hilton, muito influenciada por MacGaffey.
} 
"cristianismo" era uma ferramenta essencial para manutenção de seu status social. O acesso a esse saber de origem europeia, que incluía sacramentos, insígnias e letramento era privilégio de uma classe restrita e utilizado cotidianamente para diferenciá-la dos demais. Além disso, não era apenas o acesso aos padres europeus que esses nobres usufrúam, mas o acesso direto ao saber sacramental, formando uma espécie de "clero local", educados por capuchinhos, com os títulos de "mestres de igreja" ou "intérpretes", que ocupavam altos escalões sociais e políticos. Apesar de essa ideia ter sido aparentemente retirada das pesquisas de John Thornton (o que não está exatamente explícito no texto, tampouco nas notas), M’Bokolo faz uso dela para oferecer uma visão diferenciada sobre a importância dos elementos católicos na estruturação social e política no Congo, principalmente ao enxergar um uso do cristianismo pela lógica interna no contexto africano, na interação entre os estratos sociais congoleses:

Passava-se com o cristianismo o mesmo que ocorria com o Islã nas sociedades escravistas da Senegâmbia: a exclusão política e segregação das classes sociais inferiores era agravada por seu afastamento dos conhecimentos, que teriam podido empurrá-las para reivindicações emancipadoras. ${ }^{30}$

\section{Corpus documental}

O reino do Congo foi uma das sociedades africanas mais estudadas pela historiografia europeia e posteriormente norte-americana. Não é difícil compreendermos o motivo pelo qual esta sociedade foi posta em tamanha evidência. Primeiramente, ocorreu no Congo intenso contato por mais de três séculos com europeus, sobretudo missionários católicos. Os primeiros contatos datam de 1483, quando o grupo de exploradores portugueses comandados por Diogo Cão aportou no litoral congolês, na região de Soyo, e identificando a existência de uma sociedade politicamente centralizada passou a estabelecer parcerias comerciais com os africanos e convertê-los ao catolicismo. A partir deste fato se iniciaram embates e trocas culturais que ocorreram

\footnotetext{
${ }^{30}$ M’Bokolo, Elikia. África Negra: História e Civilizações, p. 423.
} 
até meados do século XIX, quando o Congo entrou em colapso e a ocupação colonial se efetivou.

Outro fator importante que fez com que o Congo chamasse atenção de pesquisadores africanistas era sua estrutura política, que para o olhar europeu possuía semelhanças significativas com os grandes impérios ocidentais. Quando se deram os primeiros contatos, o poder político era centralizado nas mãos do Mani Congo, havia hierarquização política e social, ritualizada materialmente pelas insígnias de poder à semelhança das mais ricas cortes europeias. Houve, portanto, uma identificação imediata pelos portugueses que chegavam ao Congo desta sociedade centro-africana com um poderoso reino europeu do antigo regime. Desde o início os portugueses associaram o soberano congolês Mani Congo a um rei; a elite vinculada a ele à nobreza: fidalgos, duques e marqueses e passaram a chamar o território de reino do Congo. ${ }^{31}$

A identificação direta dos portugueses à estrutura de poder centralizado no Congo somou-se o interesse recíproco das elites congolesas no contato com os lusos, que ocasionou em parcerias entre as coroas que duraram do início século XVI até meados do XVII. Os elementos católicos incorporados pelas elites congolesas foram essenciais para a ritualização da parceria e do imenso poder que esta trazia às elites políticas de ambos os lados do oceano. O interesse mútuo também era econômico, uma vez que o comércio se intensificou em meados do século XVI com o trato de africanos escravizados: comércio humano que envolvia elites locais e mercadores portugueses e se tornaria a principal fonte de riqueza para ambos nos três séculos seguintes.

As insígnias e sacramentos católicos apresentados pelos europeus tiveram papel essencial em todo esse contexto. O catolicismo legitimava e motivava a expansão do império português, que também tinha como objetivo a expansão da fé, uma vez que o império temporal era indissociável do império cristão. Expansão territorial e expansão da fé eram lados de uma mesma moeda.

\footnotetext{
${ }^{31}$ Anne Hilton, e principalmente John Thornton falaram desta indentificação. Hilton, Anne. The kingdom of Kongo; Thornton, John K. The Kingdom of Kongo. Civil war and transition. 1641-1718." Winsconsin press. 1983. Em alguns relatórios missionários do século XVIII a identificação das elites portuguesas com as congolesas é evidente. Por exemplo em Rafael Castelo de vide, que chama atenção para "urbanidade de português" (p 76) de alguns "nobres" congoleses". Em outra ocasião o missionário afirma que o rei do Congo José I "pouco ou nada difere dos grandes reis da Europa". Frei Rafael Castello de vide. Viagem e missão no Congo, p. 89
} 
Provavelmente os símbolos católicos foram interpretados pelos congoleses como elementos mágico-religiosos muitíssimo poderosos durante os primeiros contatos. É certo que ao serem incorporados ao vocabulário político e religioso local eles se tornavam símbolos de distinção social para a classe que os manipulava. Uma vez incorporados, esses elementos ganharam um significado particular e africano. ${ }^{32}$ Nosso objetivo central nessa dissertação é discutir o processo de "africanização" desses elementos e os novos sentidos que ganharam nas décadas finais do século XVIII, três séculos após a conversão do primeiro Mani Congo. ${ }^{33}$

A presente pesquisa tem por base documental três relações missionárias datadas do período que vai de meados ao fim do Século XVIII, que serão as principais fontes dessa dissertação. Salvo o primeiro capítulo, que trata de aspectos teóricometodológicos na historiografia sobre o Congo.

O mais completo e extenso texto disponível para o período é o do missionário franciscano português Rafael Castelo de Vide, que escreveu um relatório de mais de trezentas páginas manuscritas, descrevendo com riqueza de detalhes o trabalho no reino do Congo, onde residiu por oito anos. O religioso embarcou para a África, em missão eclesiástica, em 22 de junho de 1779 juntamente com outros dezenove missionários que se dividiram por diferentes regiões centro-ocidentais africanas. Foi uma grande empreitada cristã, que ocorreu devido ao incentivo da rainha Portuguesa D. Maria I para que missionários de diferentes ordens partissem para a região da conquista de Angola e áreas circunvizinhas. O manuscrito que dispomos é uma cópia do original, feita por Frei Vicente Salgado em 1794, que se encontra na Academia de Ciências de Lisboa ${ }^{34}$ e é a compilação de quatro diferentes relações datadas de 1781, 1782, 1783 e 1789, escritas por Castelo de Vide nas respectivas datas e enviadas separadamente a Portugal. O texto foi publicado em uma tradução italiana em 1894 por Marcelino Civezza e incluído na compilação documental em onze volumes intitulada "Storia Universale delle Missioni

\footnotetext{
${ }^{32} \mathrm{M}$ Bokolo, Elikia. África Negra: História e Civilizações, p. 42.

33“Africanização", apesar de ser um termo delicado e genérico, pretende representar o uso à maneira congolesa-africana dos elementos originalmente europeus, feito autonomamente pelos membros desta sociedade, chamando atenção para os significados novos no contexto africano. Utilizo também "incorporação", que não me parece um termo menos problemático, por enfatizar demasiadamente os sentidos originais dos elementos. Decidi também pela utilização cuidadosa de "africanização" após sugestão do Prof. Jean-Michel Mabeko-Tali, em crítica a parte deste trabalho apresentado em forma de comunicação no I Encontro Internacional de Estudos Africanos da UFF em maio de 2011.

${ }^{34}$ Rafael de Castello de Vide, Viagem ao reino do Congo (...).
} 
Francescane". ${ }^{35} \mathrm{O}$ fato desses relatórios se dividirem em quatro partes, remetidas em datas diferentes, em contextos diferentes, nos traz maiores possibilidades de questionar a documentação criticando-a internamente.

Além de ter redigido os relatórios, Frei Rafael trocou correspondências com as autoridades lusas e foi um agente importante na diplomacia pró-portuguesa no Congo. Ao menos era o que os administradores portugueses em Luanda esperavam dele. A leitura do relatório frente à contextualização mais geral que nos oferece esse conjunto de correspondências também traz interessantes possibilidades para análise de questões adjacentes às missões, determinantes na história do período. ${ }^{36}$

Os outros dois documentos missionários que utilizaremos são de autoria dos padres italianos: Raimundo de Dicomano e Cherubino de Savona. Ambos foram analisados por Susan Broadhead em sua tese de doutoramento e em trabalhos de Thornton. $^{37}$ Cherubino de Savona foi um missionário italiano franciscano que catequizou no reino do Congo de 1759 a 1774 e escreveu um sucinto, porém rico relatório de aproximadamente quarenta páginas manuscritas. Este missionário tinha grande proximidade política com as elites reinantes no Congo e por isso nos oferece uma descrição política bastante interessante. Seu manuscrito em italiano se encontra na Biblioteca Vaticana em Roma e foi publicado, na língua original por Carlo Toso e em uma tradução francesa por Louis Jadin, tornando-se assim a fonte mais conhecida sobre o período. Muito da visão que os autores citados ofereceram sobre o Congo tem influência desse relatório específico. ${ }^{38}$ Raimundo de Dicomano missionou no Congo no período posterior a Rafael Castelo de Vide, de 1791 a 1795. Seu texto também foi publicado por Jadin e também numa versão escrita por ele próprio em português, publicada por Antônio Brásio. A relação de Frei Raimundo é muito interessante pela diferença significativa dos relatos de Frei Rafael e Savona, por se tratar de um missionário capuchinho. Dicomano era evidentemente mais ortodoxo em relação à regra religiosa que os colegas. Torna-se uma fonte importantíssima por ser mais crítico da

\footnotetext{
${ }^{35}$ Civezza, Marcelino: Storia Universale delle Missioni Francescane, Scipione, Roma, 1894.

${ }^{36}$ Arquivo Histórico Ultramarino, AHU, papéis de Angola, caixa 70, documentos 8, 23, 28, 27. Possuo cópias digitalizadas das cartas também cedidas por Thornton.

${ }^{37}$ Thornton, J K. Elite women in the kingdom of Kongo: Historical perspectives on women's political power. Journal of African History, 47. Cambridge. Cambridge University Press. 2006, p. 437-60. E The origins and early history of The Kingdom of Kongo, 1350-1550. International Journal of African Historical Studies, v 34 Boston. African Studies Center. Boston University. 2001, p. 183-204.

${ }^{38}$ Toso, Carlo. Relazioni inedite di P.Cherubino C. da Savona (...), p. 135-214.
} 
relação particular dos congoleses com o catolicismo, que o fez descrever mais atentamente as práticas que tinha como degeneradas, demoníacas ou equivocadas.

O exercício que proporemos, a partir dessas fontes, é o de observar os elementos católicos africanizados a partir do prisma dos religiosos europeus e sua importância sobretudo para a manutenção e prática do poder das elites políticas. Esta naturalmente é uma tarefa espinhosa, uma vez que para um missionário de formação europeia o sentido original desses elementos de origem católica era o seu próprio. Os padres não concebiam a relação dos congoleses com os elementos cristãos como algo particular e africano, mas como uma deturpação ou no máximo uma reprodução, do sentido original. Por isso, a especificidade dos elementos católicos nesse contexto é muitas vezes ofuscada. Argumentaremos que há uma especificidade do papel dos missionários para a sociedade congolesa. Os religiosos europeus interpretavam sua posição e papel de acordo com os preceitos da ortodoxia católica europeia, uma vez que se encontravam submetidos às suas ordens de origem, ao bispado e em ultima instância ao Vaticano. Mas estando em território congolês estavam também subjugados a um sistema operador de elementos católicos sob uma lógica própria congolesa. Em outras palavras, os missionários muitas vezes não compreendiam a lógica de funcionamento do sistema político-religioso no qual estavam inseridos, o que torna o uso destas fontes para acesso às especificidades africanas ainda mais desafiador e em contrapartida extremamente instigante.

O primeiro capítulo será introdutório e particular em relação aos três demais, pois não tratará das fontes históricas, trazendo questões teórico-metodológicas presentes no debate historiográfico sobre o reino do Congo. Partiremos de dois trabalhos contemporâneos entre si, ambos dos anos 1980, escritos pelos autores John Thornton e Anne Hilton. $O$ texto apresentará a maneira particular com que cada um desses trabalhos buscou atender ao desafio de buscar a "voz africana" praticamente silenciada na maioria das fontes, desta maneira debateremos os limites e contribuições das diferentes metodologias de trabalho com a documentação de época.

Do segundo ao quarto capítulo, trabalharemos essencialmente com as fontes selecionadas para a pesquisa, dividindo os capítulos entre grandes problemáticas.

O segundo capítulo, apresentará criticamente as fontes históricas primárias e os personagens presentes nelas, principalmente aqueles que as redigiram e seus 
interlocutores. Este capítulo, ao contrário dos posteriores, tratará mais de perto da relação dos congoleses com a missão e seus agentes. Por isso, terá uma função mais factual e um modelo mais narrativo. Além disso, ele contextualiza o comércio de escravos e a relação com a colônia portuguesa em Luanda. Temas importantes para compreendermos questões adjacentes à missão católica e possibilitar uma abordagem mais profunda da documentação.

Sobre o terceiro capítulo, seu foco é a relação do catolicismo com as práticas de poder central do Congo, assim como sua legitimidade. Buscamos compreender a essencialidade das práticas originárias do catolicismo para a ritualização cotidiana do poder do rei do Congo e da elite política vinculada ao poder central, sediado na capital de S. Salvador.

O quarto capítulo terá objetivo semelhante ao terceiro, porém estará mais diretamente focado nas elites locais. Debateremos cada uma das principais províncias que compunham o reino (ou "império") do Congo pós-restauração. Apresentaremos as diversas particularidades entre elas, assim como o denominador comum que argumentaremos ser a pertença indenitária ao Congo. O catolicismo aparecerá novamente como elemento central para a manutenção deste sistema, conferindo diversos graus de legitimidade aos atores locais. Abordaremos algumas práticas rituais (sobretudo o casamento) como atribuidores de legitimidade politica à elite provincial. Debateremos a importância dos especialistas rituais congoleses ligados ao catolicismo (mestres, intérpretes e nlekes), também trataremos da escrita como ferramenta de poder. 


\section{Capítulo 1: Traduções e Incorporacões: uma leitura da historiografia sobre o}

Congo

O olhar para diferentes culturas em contato tem sido um objeto muito interessante para a historiografia recente. A África centro-ocidental, a partir do século $\mathrm{XV}$ foi palco de intenso contato entre europeus, que chegavam à costa africana com o intuito de comerciar e catequizar, e as diferentes sociedades africanas que ali se encontravam. Nesse sentido, o Congo é uma sociedade privilegiada para o historiador africanista. Ali ocorreu intenso contato entre europeus e africanos durante quatro séculos, com consequências interessantes e únicas para essa sociedade. A presença europeia no interior do território congolês foi constante desde as décadas finais do século XV ao XIX, principalmente de missionários portugueses e italianos que trabalharam intensamente na capital Mbanza Congo, assim como nas vilas e aldeias no interior. No Congo, mais do que em outros locais da África, ocorreu uma incorporação e ressignificação de elementos religiosos originalmente cristãos dentro das lógicas locais, com importância chave para a legitimação do poder de parte da elite política, o que transformou a organização social e religiosa da sociedade congolesa. Graças à excepcionalidade desses contatos, que geraram trocas e ressignificações dos elementos de origem europeia, temos sobre o Congo considerável corpus documental, principalmente de autoria europeia missionária. Por conseguinte, o Congo também se tornou objeto privilegiado para historiadores e antropólogos nos últimos cinquenta anos, assim como na atualidade.

Este primeiro capítulo pretende discutir e problematizar, à luz dos mais significativos trabalhos histográficos e antropológicos sobre o Congo, as principais teorias sobre as trocas e ressignificações entre as culturas europeia e africana. Isso será importante para os capítulos posteriores, pois o trabalho com os documentos exigirá a explicitação e problematização das metodologias ao tratar dos encontros culturais.

A questão principal que perpassa as principais obras historiográficas sobre o Congo do ponto de vista teórico-metodológico seria os questionamentos quanto a possibilidades do uso de instrumental antropológico no trabalho de história da cultura como uma lente privilegiada para o lado africano obscurecido pela unilateralidade da documentação histórica. Veremos que há uma discordância quanto a isso na 
historiografia sobre o Congo e que tal diferença de abordagem frente ao instrumental antropológico é fator determinante para os diferentes resultados históricos alcançados pelos trabalhos.

Discutirei os principais autores em três partes, primeiramente veremos os dois principais antropólogos que estudaram o Congo: Georges Balandier e Wyatt MacGaffey, sobretudo o último deles. Na segunda parte discutirei dois entre outros estudiosos que são mais abertos para influências antropológicas: Anne Hilton e Marina de Mello e Souza. Na terceira parte discutirei as ideias daquele que é tido como principal estudioso do Congo: John Thornton, que por sua vez assume uma posição diferente dos anteriores e apresenta uma tese marcante sobre a constituição dos contatos entre europeus e congoleses na história do Congo em geral, pretendendo uma interpretação essencialmente histórica sobre essa sociedade.

Não pretendo aqui chegar a conclusões definitivas, nem assumir uma ou outra posição, apenas observar como a influência da antropologia se manifesta de maneiras diferentes nos trabalhos que serão discutidos. Essa pluralidade de estratégias metodológicas e interpretações históricas demonstra quão instigante e relevante são os debates sobre os encontros de culturas no seio da sociedade congolesa e como a historiografia africanista contribui de maneira inovadora para a disciplina histórica como um todo.

\section{$\underline{1.1 \text { Trabalhos antropológicos }}$}

O antropólogo francês Georges Balandier foi um dos pioneiros no estudo da história do reino do Congo: seu trabalho "Vie quotidienne au royaume du Kongo"39 foi publicado em 1965, período no qual grandes compilações documentais já circulavam. ${ }^{40}$ Nesse trabalho, Balandier tem como objeto a história do reino do Congo, desde os primeiros contatos com os portugueses, no fim do século XV até sua suposta derrocada, datada pelo autor da segunda metade do século XVII. O antropólogo afirma utilizar uma metodologia diferenciada para a leitura documental, apresentando uma postura muito

39 Balandier, G. Daily life in the Kingdosm of Kongo. p. 49-64.

40Cita publicações de fontes: 1877 Levy Maria Jordão e Paiva Manso trabalho continuado por Albuquerque Felner em 1933; Pe Antonio Brasio: Monumenta Missionária Africana 1953-54; Couvelier em colaboração com Louis Jadin publicou um enorme grupo de documentos em 1954: L'Ancién Congo d'apres les archives romaines(1518-1640). 
crítica em relação aos métodos utilizados por historiadores que o precederam. ${ }^{41} \mathrm{O}$ autor crê que a vasta documentação missionária disponível sobre o Congo tem valor relativo por ser repleta de preconceitos, distorções e interesses europeus que, para ele, maquiariam uma suposta "verdade" que reside na especificidade africana não documentada. Por isso, para o autor, aqueles que utilizam apenas fontes de época para realizar o trabalho histórico cairiam ingenuamente na armadilha do olhar europeu sobre os africanos. A alternativa metodológica encontrada pelo antropólogo para fugir da dita armadilha é o uso de fontes etnológicas contemporâneas sobre os povos de língua kikongo, descendentes dos habitantes do antigo reino. "A veritable process of translation, guided by sociological and ethnological knowledge, is often necessary; not just necessary but fruitfull". ${ }^{42}$ Para Balandier, mais do que complementar às fontes históricas, o trabalho sociológico contemporâneo deve guiar a leitura das mesmas, afirmando que as fontes devem passar pelo crivo das etnologias, que confeririam ou não sua validade.

Balandier justifica seu método por um pressuposto de fixidez, que permite aproximar os bacongo contemporâneos dos antigos habitantes do reino do Congo. $\mathrm{Na}$ opinião do antropólogo, não houve mudança significativa na base estrutural e mental da sociedade do século XV ao XX, o que garante a utilidade das etnologias modernas. A organização das estruturas sociais, o vocabulário da realeza, organização dos clãs, organização da vida material e do trabalho pertenceriam, segundo ele, a uma estrutura que se manteve basicamente estática ao longo de quatro séculos.

A obra de Balandier é marcada por uma visão incisiva sobre os significados da cristianização no Congo, sintomática de sua opção metodológica. Para o autor, o rei cristão D. Afonso I Mvemba a Nzinga foi um grande estrategista e "modernista". Afonso teria utilizado a religião europeia unicamente como uma estratégia de conquista de poder e legitimidade política, que não teria pelos meios tradicionais. Desta forma, o rei do Congo buscou transformar a tradição política e aglutinar grande poder em suas mãos utilizando os elementos apresentados pelos portugueses nos primeiros contatos. Balandier não acredita que a estratégia afonsina tenha sido vitoriosa. Para ele, com o

\footnotetext{
41Seus principais antecessores foram Van Wing, Joseph: Études Bakongo. Bruxelas, 1921. Jean Cuvelier: L'Ancién Royaume de Congo, Bruxelas, 1946. e Randles, W.G.L: L'Ancién royaume du Congo. 1968.
}

42Balandier, G. Daily life in the Kingdosm of Kongo. , p.49 
fim do seu longo reinado acabou também o "casamento falso" entre cristianismo e a realeza no Congo.

No que tange o esforço historiográfico do autor pode-se afirmar que o trabalho de Balandier apresenta muitos problemas do ponto de vista da seleção das fontes e da metodologia. Ele prioriza absolutamente seu trabalho empírico de campo entre os bacongo e invalida fontes históricas, acusando-as de mentir e oferecer uma visão parcial e preconceituosa dos africanos. Ao invés de realizar a critica das fontes ele opta por ignorar aquelas que não corroboram sua tese, impossibilitando a percepção dos processos de transformações (processos históricos) e ressignificações de elementos de diferentes origens dentro da lógica congolesa, pois seu olhar se encontra sempre preso a uma suposta tradição imutável.

Discutiremos, em seguida, outro importante autor dentro da tradição antropológica. Wyatt MacGaffey, responsável pelo trabalho de antropologia mais importante sobre os bacongo, publicou seus primeiros trabalhos na década de 1970, dentre eles "Religion and Society in Central Africa",43, assim como dezenas de importantes artigos e alguns livros. MacGaffey realiza estudos em antropologia da religião, para os quais sua ferramenta privilegiada é a cosmologia bacongo. Seu olhar cosmológico viria a influenciar muitos outros autores que pesquisaram o Congo.

Define cosmologia como o corpo de representações coletivas do mundo, ordenando o espaço, o tempo e o lugar do homem. Esse conjunto de normas simbólicas é inconsciente para os seus detentores, por isso suas "regras" não podem ser percebidas internamente. $\mathrm{O}$ autor critica a visão anterior que Geertz ofereceu sobre cosmologia: restrita a um "sistema cultural". Para MacGaffey a cosmologia vai muito além, pois rege toda a organização social, política e econômica das respectivas sociedades. ${ }^{44}$

O conceito de "inconsciente" de MacGaffey vem de uma tradição antropológica fundada por Claude Levi-Strauss ${ }^{45}$ em meados do século XX e foi inicialmente elaborada baseada no conceito de inconsciente da linguística, que difere da definição

43 Macgaffey, Wyatt-Religion and society in Central Africa: The Bacongo of the lower Zaire. Chicago. Chicago Univ. Press. 1986. Seu primeiro trabalho e o de maior impacto foi Custom and Government in the Lower Congo. Berkley, University of California press, 1970. Também: Religious Commissions of the Bakongo. Royal Anthropological Institute of Great Britain and Ireland, V 5, no1. 1970, p.27-38.

44Macgafffey, Wyatt. Religion and society in lower Zaire, $p 18$.

45Levi-Strauss, Claude. As estruturas elementares do parentesco. Petrópolis, Vozes, 1982 e Levi-Strauss, Claude. O pensamento Selvagem. São Paulo, Papirus, 2008, neste o autor determina com mais clareza as estruturas subconscientes como organizadoras da vida social dos indígenas brasileiros. 
freudiana. ${ }^{46}$ As estruturas elementares do parentesco, para Levi-Strauss, e a cosmologia, para MacGaffey, regem todos os âmbitos da vida social, operando da mesma maneira com que um sistema linguístico organiza a comunicação. Para o estruturalismo linguístico, que teve como pioneiro Saussure, a comunicação entre pessoas que compartilham um mesmo idioma se dá naturalmente, sem que as regras estruturais da língua sejam percebidas. Essas regras, porém, determinam os limites e possibilidades, organizando o pensamento e a comunicação entre membros desse mesmo grupo. Para MacGaffey é assim que a cosmologia opera na sociedade, por isso o estudo do sistema religioso congolês (a cosmologia não se limita a um sistema religioso, justamente) é essencial para a compreensão de todo e qualquer nível da vida social, política ou econômica. Ele chama atenção para o fato de que a separação dos papéis: políticaEstado, religião-Igreja, economia-mercado é uma separação ocidental capitalista, não é uma separação lógica e não vale para as sociedades africanas em geral.

Apesar desse viés teórico estruturalista, MacGaffey, ao contrário de Balandier, assume possibilidades de mudanças internas e externas no sistema cosmológico bacongo. Nos séculos XVI e XVII, por exemplo, observou a importância do culto de espíritos locais formando uma única hierarquia coexistente com a estrutura política do Congo. Já nos séculos XVIII e XIX essa hierarquia rígida se quebra em cultos locais de menor escala. Apesar da função desses cultos continuar semelhante, a organização hierárquica se fragmenta, o que tem relação intrínseca com a fragmentação do sistema político centralizado e das linhagens.

Em sua interpretação do papel dos elementos cristão no Congo o antropólogo o compreende pela relação entre duas estruturas cosmológicas: portuguesa cristã e "bacongo". No seu entender, a aceitação do batismo pelos membros da elite congolesa se deu por traduções e leituras dos elementos cristãos pela tradição africana. O retorno dos reféns congoleses em 1485, que foram capturados na costa anos antes e levados para Lisboa, segundo MacGaffey, foi o evento marcante para a aceitação do cristianismo, uma vez que representou um rito de passagem para um universo novo, cujo acesso podia oferecer o alargamento do poder das elites congolesas.

O entendimento bacongo do além-mar como uma esfera separada se justifica pela arquitetura básica da sua cosmologia, que o antropólogo definiu pela experiência 
empírica nas regiões "bacongo" contemporâneas. Ela se constitui pela divisão entre dois mundos, representados por duas montanhas: a dos vivos e a dos mortos, separadas pela base por água (Kalunga). Os congoleses do século XVI teriam identificado os brancos vindos do mar como habitantes do mundo dos mortos e por isso o retorno dos reféns teria sido uma excepcional iniciação, que abriria um novo canal de comunicação entre as elites congolesas e as poderosas forças dessa esfera.

MacGafffey definiu essa relação entre as cosmologias bacongo e cristã como a "institucionalização de um mal entendido", uma vez que a tradução dos elementos lcatólicos pela cosmologia bacongo fez com que esse contato fosse eficaz, mesmo que estabelecido por falsos pressupostos. Ao mesmo tempo, os missionários responsáveis pela evangelização compreendiam a conversão ocorrida dentro dos padrões religiosos católicos. O batismo nessa ótica possuía um significado de purificação e aceitação completa da nova e verdadeira fé, por isso, o mal entendido seria mútuo, como uma tradução que mesmo mal feita possibilitou a comunicação. Um "diálogo de surdos" que mediou as relações entre as culturas africana e europeia no reino do Congo durante séculos. ${ }^{47}$

As ideias de MacGaffey não repercutiram com muito sucesso entre os antropólogos africanistas em geral, mas causaram grande impacto nos trabalhos dos principais historiadores especialistas no Congo. Em meados dos anos de 1970 e 80, enquanto o antropólogo publicava seus trabalhos, os principais estudiosos do Congo iniciavam suas pesquisas e foram bastante influenciados por ele. Com a exceção de John Thornton, que discutiremos mais tarde, os historiadores se utilizaram do vocabulário cosmológico de MacGaffey como suporte do trabalho com as fontes, o que demonstra a importância de sua influência para os rumos dos trabalhos de história do Congo. No campo metodológico, observaremos como essa influência se deu e como dividiu a historiografia.

47Macgaffey, Wyatt. Dialogues of the deaf: Europeans on the Atlantic coast of Africa. In: Schwatz, S. Implicit Understandings. Observing, reporting, and reflecting on the encounters between Europeans and other peoples in the Early modern era. Cmbridge, Cambridge Univ. press, 1996. Esse artigo de MacGaffey traduz bem sua concepção de cristianismo, mas não é o primeiro, ideias semelhantes foram formuladas em trabalhos anteriores já citados. 


\section{2: História e Cosmologia}

O trabalho da historiadora inglesa Anne Hilton, publicado nos anos 1980, é um exemplo de trabalho histórico muito influenciado pelo vocabulário antropológico de MacGaffey. Hilton escreveu um trabalho de história geral do Congo nos séculos XVI e XVII. O primeiro capítulo de seu livro já demonstra claramente sua opção metodológica que perpassaria todo o livro. Descreve o Congo em termos gerais, em sua geografia, organização social, econômica e religiosa. No tocante à religião, Hilton utiliza como "arquitetura simbólica" a abordagem cosmológica de MacGaffey. Descreve a visão de mundo bipartido em dois mundos que possuem relação simétrica entre si, sendo divididos pela base pela kalunga. Hilton enfatiza os diferentes tipos de forças invisíveis: aquelas originárias de outra esfera e manifestas na natureza (mbumba), a do mundo dos mortos, as originárias de nkadi mpemba, os espíritos locais, entre outros. Também resume as maneiras de manifestação dessas forças através de minkisi, nganga(s), Mani(s), kindoki, kitomi e de elementos da própria natureza, além de dar grande destaque aos ritos funerários e à atuação dos mortos e ancestrais na vida social. ${ }^{48}$

Pode-se afirmar que Hilton faz uma compilação cosmológica, organizando em poucas páginas o extenso trabalho de MacGaffey e de "self-ethnographers" como FuKiau Busseque. O trabalho de Fu-Kiau tornou-se importante por ter oferecido uma representação gráfica da cosmologia básica congolesa: o cosmograma bacongo. Hilton apresenta o mapa cosmológico proposto por $\mathrm{Fu}$-Kiau para expor de maneira gráfica a organização simbólica congolesa do mundo, ponto de partida para seu criterioso trabalho com as fontes.

Uma das características que faz o trabalho de Hilton interessante e inovador é a maneira como agrega o instrumental antropológico na pesquisa empírica das fontes. Um exemplo que vale citar é a narrativa dos primeiros contatos entre portugueses e a elite congolesa em Soyo e o posterior "batismo" do Mani Congo. Para tal, utiliza documentação europeia que narra esse encontro. Mesmo utilizando narrativas europeias, busca reconstituir os fatos através da perspectiva dos congoleses e isso fica claro quando narra os fatos através do olhar do africano. Essa virada narrativa só foi possível

\footnotetext{
${ }^{48}$ Hilton, Anne. Kingdom of Kongo, p. 28.
} 
com o uso do material cosmológico dos bacongo contemporâneos, que permitiu que Hilton especulasse sobre o olhar africano não documentado no século XV.

Ao tratar da incorporação de elementos católicos no Congo, Hilton também utiliza método semelhante. Ela busca definir, de acordo com o mapa cosmológico de Fu-Kiau, o local ocupado pelos ritos católicos na mentalidade congolesa. Para Hilton o cristianismo no Congo nos séculos XVI e XVII era quase exclusivamente relacionado à dimensão do mundo dos mortos e os padres (ngangas) católicos tinham sua importância central na mediação entre os vivos e os ancestrais e sua atuação era quase exclusiva em rituais fúnebres. As igrejas, por sua vez, tornaram-se locais de mediação das forças dos mortos (assim como túmulos e rios). Hilton apresenta evidencias em documentação missionária da construção de igrejas por diferentes reis do Congo para abrigar seus túmulos após a passagem para o outro mundo. Os santos padroeiros dessas igrejas seriam os agentes privilegiados dessa mediação, cada soberano escolheria um santo de acordo com sua linhagem patrilinear, e esses teriam funções específicas de proteção e assegurariam uma boa relação dos chefes com sua ancestralidade.

Além dos reis, os mwissikongo (elite congolesa) seriam os beneficiários principais dessa relação privilegiada com o mundo dos mortos via ritos católicos. Hilton não parece acreditar que até meados do século XVII o cristianismo tenha atingido significativamente camadas mais baixas da população. Apesar disso, ela admite uma exceção a essa regra no que diz respeito aos artefatos religiosos. Cruzes, água benta, sais, imagens da virgem, rosários, entre outros, eram minkisi comuns entre a população congolesa, que os carregavam como amuletos de proteção contra a ação de kindoki (feiticeiros), com o objetivo de neutralizar doenças e malefícios cotidianos. A historiadora admite a importância dos artefatos isolados como elementos incorporados à cosmologia religiosa popular, mesmo entendendo que não causaram mudanças significativas nessas estruturas.

Hilton admite outra exceção à relação direta de ritos católicos com os ancestrais mortos: o culto à Virgem, que teria alcance popular. O poder da Madona estaria relacionado com a fertilidade das terras e das mulheres, o que em geral não diz respeito ao mundo dos mortos e sim à mbumba (forças da natureza). Nesse caso um elemento introduzido pelo cristianismo escapa à relação com a ancestralidade e a exclusividade dos mwissikongo. A Virgem também era interpretada como uma chefe auxiliar ao grande chefe Kristu Mfumu (Jesus Cristo). Hilton introduz essa importante exceção da 
Madona mostrando que no final do século XVII e início do XVIII houve uma mudança do significado simbólico desses elementos cristãos incorporados. Com o enfraquecimento do Mani Congo, dos mwissikongo e a desorganização do sistema de linhagens, os elementos cristãos se tornam cada vez mais associados às forças da natureza (mbumba), ocorrendo desta maneira maior popularização do cristianismo entre as camadas mais baixas da população, que tinham mais acesso às forças manifestas na natureza. Essa demanda de incluir o culto mariano no esquema histórico-cosmológico que criou é claramente uma demanda da documentação missionária, que cita constantemente, sobretudo no século XVIII, a presença de "ladainhas de nossa senhora" e outras formas de culto à virgem. $\mathrm{O}$ que demonstra a vocação historiográfica de seu trabalho e a delimitação do instrumental antropológico a um instrumento auxiliar à leitura de fontes. ${ }^{49}$

Um exemplo contemporâneo de estudo histórico que segue a mesma tendência "cosmológica" de Anne Hilton é o trabalho de Marina de Mello e Souza sobre os crucifixos produzidos no Congo, por meio dos quais a autora debate a incorporação e ressignificação dos símbolos católicos pela lógica mental congolesa. Houve no Congo, a partir de meados do século XVII e principalmente no XVIII a intensa produção de crucifixos de bronze com a imagem de Jesus crucificado, os nkangi kiditu em kikongo. Apesar de seguir um padrão imagético católico apresentam diversas características estéticas típicas da tradição congolesa. Na busca de desvendar tais documentos tão instigantes a historiadora recorreu aos trabalhos de cosmologia de MacGaffey e Fu-Kiau na tentativa de interpretar o significado que os objetos assumiam para aqueles que os produziram e carregavam. ${ }^{50}$

\footnotetext{
49Hilton, Anne. Kingdom of Kongo, p 36. O culto à Virgem Maria é muito recorrente nos relatórios do século XVIII de Raimundo de Dicomano e Rafael Castelo de vide, neste ultimo fica claro também o grande valor que as imagens da santa possuem entre os congoleses de todos os extratos sociais: Rafael de Castello de Vide, Viagem ao reino do Congo. Brasio, Informação do Reino do Congo de Frei Raimundo de Dicomano. Revista Studia XXXIV. Lisboa. 1972. 19- 42. Utilizei a tradução do documento original feita por Arlindo Correa, que é posterior e corrige alguns lapsos cometidos por Brásio, com base no documento original, simultaneamente publicado: Correa, Arlindo. Informação o reino do Congo por Raimundo Dicomano (1798). 2008. Publicado eletronicamente em: http://www.arlindocorreia.com/101208.html. Simultaneamente como o texto original em italiano: Correa, Arlindo. Informazione sul regno del Congo di Fra Raimondo da Dicomano (1798). 2008. Publicado eletronicamente em: http://www.arlindo-correia.com/121208.html
}

50 Souza, Marina de Mello e. Central Africans crucifixes. A study of symbolic translations. In: Jay A.Levenson. (Org.). Encompassing the Globe. Portugal and the World in the 16th and 17th Centuries. Essays. Washington DC, Smithsonian Institution, 2007, p. 97-100. 
A autora reconta a história da conversão do primeiro Mani Congo e da elite ligada a ele, destacando o episódio citado pela narrativas de Rui de Pina que envolvia uma pedra cruciforme, encontrada por um chefe congolês no dia seguinte do seu batismo. Utiliza a interpretação de MacGaffey que definiu um "diálogo de surdos" nas traduções entre cosmologias europeia e congolesa como regentes do processo de “conversão". Utiliza também o cosmograma bacongo de Fu-Kiau, no qual o símbolo da cruz está presente no cruzamento entre as linhas que limitam os diferentes planos da existência. Assim, Marina descreveu a cruz como símbolo da conexão entre os mundos visível e invisível (duas montanhas que dividem a mesma base). Para Fu-Kiau, os quatro pontos da circunferência na qual a cruz está inscrita materializam a comunicação entre os dois mundos, sendo também o caminho percorrido pelo sol, movimento cíclico diário que simboliza o equilibrio. A partir da exposição desse sentido do símbolo cruciforme para a tradição bacongo, Marina de Mello e Souza afirma que a cruz seria um símbolo comum entre as cosmologias portuguesa e bacongo, que mesmo possuindo significados diferentes permitia a comunicação via tradução entre sistemas simbólicos. Esse sentido duplo permitiria a popularização dos crucifixos no Congo de maneira natural e desvinculada dos significados originários do catolicismo.

Ambos os trabalhos históricos citados enxergaram o contato cultural numa chave de "traduções". Ambas as estudiosas buscaram dar sentido dentro de um sistema cosmológico congolês aos símbolos católicos da cultura europeia, explicando desta maneira a aceitação e a penetração de símbolos novos na tradição religiosa africana. A palavra "tradução" é muito sintomática de uma ideia antropológica de cultura, na qual as culturas operam como sistemas linguísticos.

Há na historiografia e principalmente antropologia brasileira uma vertente que trabalha em linha semelhante a "História cosmológica" sobre o Congo. Seu olhar recai sobre os contatos culturais no contexto das missões católicas na América portuguesa colonial. Esta bibliografia também busca compreender as relações de "mediação cultural" entre duas estruturas religiosas, que se interpretariam mutuamente por seus "idiomas" culturais originais. Porém, neste contexto, os atores se debruçam sobre populações indígenas americanas e os padres da Cia de Jesus, responsáveis pela suposta salvação das almas do "Novo Mundo". A ideia de "mediação cultural" ou de "estruturas de mediação" (de Paula Monteiro) privilegia o olhar para as "zonas de contato", ou seja, os mecanis mos pelos quais ocorreriam as traduções mútuas. Esta escola de "antropologia-histórica" também mescla (em sua metodologia) documentação histórica e trabalhos antropológicos mais recentes. Monteiro, P. Deus na Aldeia. São Paulo, ed. Globo, 2006. e Pompa, C. Religião como tradução: missionários, Tupi e Tapuia no Brasil colonial. São Paulo, Edusc, 2003. 
A tradução cultural funcionaria como troca de significado entre dois sistemas paralelos, que não se transformam significativamente durante o contato, pois a leitura de um sistema ao outro é sempre feita a partir do sistema natural, sem colocá-lo em cheque. Além disso, para aceitar utilizar cosmologias recolhidas contemporaneamente como válidas para o século XVIII ou mesmo XVI, há que se pressupor uma fixidez na longa duração, o que pode ser delicado para um trabalho historiográfico.

Mesmo com ressalvas do uso de instrumentos antropológicos nos processos históricos de longa duração, essa metodologia nos oferece a possibilidade interessante de tentativa de aceso aos significados especificamente congoleses de símbolos e ritos de origem católica, exercício limitado (e árduo) para a metodologia que trabalha apenas com as fontes escritas europeias.

\section{3: Similitudes e incorporação}

Trataremos agora de um viés interpretativo e metodológico bastante diferente dos anteriores. Se a base da interpretação nos trabalhos citados de Anne Hilton e Marina de Mello e Souza são a cosmologia e as traduções culturais; o viés de John Thornton se baseia em similitudes e incorporação. Thornton é considerado o maior especialista atual na história do reino do Congo, com numerosos trabalhos publicados e extensa pesquisa documental realizada nas ultimas três décadas. ${ }^{51} \mathrm{O}$ trabalho de Thornton é particular sob diversos aspectos, mas focaremos na questão metodológica e na significativa diferença que seu trabalho tem dos citados anteriormente no que tange os objetivos, metodologia e os resultados interpretativos sobre os produtos do contato cultural entre portugueses e congoleses. Particularidades que, acredito, são fruto da atitude diferenciada de Thornton diante do instrumental antropológico para a realização do trabalho historiográfico.

51 Thornton, John. The Kingdom of Kongo; e The Kongolese Saint Anthony. Dona Beatriz Kimpa Vita and the Anthonian moviment. Além de importantes artigos mais sintéticos sobre cristianismo no Kongo, destaca-se Religious and cerimonial life in Kongo and Mbundo areas. 1500-1700. In Central Africans and Cultural Transformations in the American Diaspora. Heywood, Linda (org). Cambridge, Cambidge Univ. press, 2002. Seu trabalho mais recente é Heywood, L e Thornton J. Central African Creoles and the Foundation of the Americas, 1585-1660. Cambridge, Cambridge Univ Press, 2007. Transformations in the American Diaspora. Org Linda Heywood. Cambridge, Cambidge Univ press, 2002. 
Primeiramente, é importante observarmos que o olhar de Thornton é direcionado principalmente ao produto do contato entre culturas e não no processo em si. Ou seja, as traduções de ambas as partes, que possibilitaram o contato são secundárias em seu trabalho diante do resultado do contato, que para ele é a formação de uma cultura híbrida católica congolesa, ou crioula (como denominou em trabalho recente). O campo religioso é um objeto que privilegiamos em nossa discussão, portanto, discutiremos a ideia de Thornton sobre a formação de um cristianismo congolês como eixo para o debate mais amplo. Tratarei de sua ideia, presente em obras mais antigas, de formação de uma igreja católica africana no Congo e em seguida de seu trabalho mais recente, que vai além, aderindo o conceito de "crioulos atlânticos". 52

$\mathrm{O}$ autor possui uma tese muito marcante e polêmica no aspecto religioso sobre o Congo, pois foi o primeiro a defender que houve uma conversão de fato dos congoleses ao cristianismo, processo no qual as elites do Congo tiveram papel ativo, que resultou num tipo particular de prática cristã e na formação de uma igreja católica institucionalizada no reino do Congo. ${ }^{53}$ Ele flexibiliza e historiciza as tradicionais noções estruturais, admitindo a possibilidade da incorporação ativa de um novo sistema religioso pelos africanos, feita por iniciativa própria e dentro da lógica particular dessa sociedade.

A compatibilidade do cristianismo ao "sistema religioso tradicional" foi feita, segundo Thornton, através de um "sistema de revelações". Ambos os sistemas religiosos, congolês e católico, tinham na revelação um elemento essencial de seu funcionamento e o diálogo foi possibilitado pelo compartilhamento de algumas revelações. Primeiramente, um conjunto de sinais (como sonhos e a já citada pedra cruciforme) recebidos pelas elites governantes mostrava que os símbolos de poder trazidos pelos portugueses eram legítimos e poderosos. A revelação decisiva ocorreria alguns anos após o batismo do Mani Congo Nzinga a Nkuwu, em um contexto de disputas internas sucessórias entre seus filhos, que discordavam sobre o cristianismo. A vitória do rei pró-cristianismo D. Afonso Mvemba a Nzinga pela intervenção divina da imagem de S. Tiago abriu definitivamente espaço para a legitimidade dos elementos cristãos dentro do sistema religioso dos congoleses.

52Heywood, Le Thornton J. Central African Creoles and The Foundation of the Americas. 2007.

53Thornton, em geral, prioriza a terminologia política "congolesa" à denominação étnico-linguística "bacongo"; para o autor a unidade política é o fator identitário mais determinante nas sociedades da África centro-ocidental e não o fator linguístico. 
Outro fator importante foi a atuação das elites religiosas congolesas nesse processo; figuras importantes como D. Afonso I, segundo Thornton, foram essenciais para disseminar e permitir uma apropriação do cristianismo pelos africanos. Thornton enfatizou que o Mani Congo Afonso impressionou muitos europeus pela sua dedicação ao estudo dos preceitos cristãos e pelo conhecimento dos livros religiosos e suas discussões teológicas com padres. Além disso, seu filho D. Henrique, foi enviado para estudar em Lisboa e foi consagrado bispo, atuando no Congo de 1518 a 1531. Afonso também montou uma estrutura educacional, com escolas de gramática e religião para as elites, ensinadas por professores locais, que foram mantidas no reinado de seu sucessor Diogo I. ${ }^{54}$

Além das revelações, Thornton chama atenção para a característica da própria missão como incentivadora do desenvolvimento do catolicismo no Congo. Os padres iam ao reino como convidados do Mani Congo e sua sobrevivência dependia do consentimento de seu trabalho dado pelas elites e população local. Isso fez com que essas missões possuíssem um caráter absolutamente diferente da missão colonial nas Américas, marcadas pela problemática do colonialismo e escravidão. Para Thornton a missão no Congo era "inclusiva" ao invés de "exclusiva"; o que significa que quaisquer atitudes que não ferissem drasticamente os preceitos católicos eram aceitas, o que ocorreu em menor grau nas colônias. Além disso, para traduzir os termos religiosos cristãos os missionários usavam palavras em kikongo: como Nzambi Mpungu para Deus, moyo para alma e nkisi para sagrado. O primeiro catecismo em kikongo foi publicado em 1555 por jesuítas e pareceu, para Thornton, ter tido grande uso no trabalho missionário. Para o autor, essas características permitiram uma aceitação popular e uma compreensão particular do catolicismo pelos congoleses. Os missionários ensinavam, batizavam e pregavam, mas não possuíam instrumentos de controle da população, uma vez que eles próprios eram submetidos aos reis do Congo. Portanto, para Thornton, o produto dessa missão não foi a dominação ou imposição de preceitos ortodoxos europeus, e sim o estabelecimento de um cristianismo "nacional" e popular congolês. ${ }^{55}$

\footnotetext{
${ }^{54}$ Heywood, Linda e Thornton J. K...Central African Creoles and The Foundation of the Americas, p. 170172.

55Thornton, John. The development of an African Catholic Church in the Kingdom of Kongo, p. 147167.
} 
Thornton afirmou que o primeiro meio século de contato com os portugueses e o posterior trabalho de catequese promovido pela elite local foi responsável pela transformação radical da tradição religiosa congolesa. Em outros termos; os próprios congoleses, diante do novo repertório europeu, incorporaram diversas "novidades" e voluntariamente transformaram o sistema tradicional em um novo sistema, um sistema sincrético: uma nova linguagem que não exige traduções pois opera com a mesma naturalidade termos europeus e africanos, pois ela mesma teria ganho novo sentido na incorporação.

Essa tese é levada além quando o autor vê no Congo a gestação de uma cultura "crioula atlântica", o que aparece em seu livro mais recente, escrito em parceria com a historiadora Linda Heywood. ${ }^{56}$ Essa ideia é fundamentada no trabalho do historiador Ira Berlin, que estabelece o espaço atlântico como um espaço de crioulização, primeiro momento da gestação da chamada cultura afro-americana. O debate sobre contatos culturais, "crioulização" e origem da cultura afro-americana nos Estados Unidos é bastante polarizado e complexo, mas não nos aprofundaremos nele especificamente. ${ }^{57}$ Relevante para o nosso trabalho é o fato de Thornton levar ao limite o conceito de Berlin de "crioulos atlânticos", trazendo sua origem para o a África centro-ocidental e colocando o Congo como precursor e principal agente deste processo. ${ }^{58} \mathrm{O}$ próprio conceito de crioulização que Thornton e Heywood trazem nesse trabalho só faria sentido, para ambos, tendo o Congo como padrão, pois para eles é o exemplo máximo (e talvez único) de incorporação de elementos da cultura europeia nos moldes locais. Sendo o Congo a referência máxima do processo de crioulização, para Thornton e Heywood, as demais sociedades centro-africanas que interagiram com os portugueses na África central teriam sofrido uma crioulização de menor grau e a partir daí se estabelece um mapeamento dos "graus de crioulização" de cada uma delas.

Através da defesa da existência do "catolicismo congolês" que evolui para uma "cultura crioula" o autor defende a existência de um processo de total ressignificação no sistema religioso e social congolês. Esse processo se justificaria a partir da premissa do

56Heywood, Le Thornton J. Central African Creoles and The Foundation of the Americas, 1585-1660. Cambridge. Cambridge University Press. 2007.

57Para uma análise crítica bastante aprofundada destes debates culturalistas sobre a diáspora africana nas Américas ver: Marcussi, Alexandre A. Diagonais do Afeto Teorias do intercâmbio cultural nos estudos da diáspora africana. Dissertação de Mestrado. Universidade de São Paulo. 2010.

58Berlin, Ira. Many Thousands Gone: The First Two Centuries of Slavery in North America. Cambridge. Harvard University Press, 1998. 
autor, que a partir da leitura das fontes, chega às similitudes entre a cultura católica europeia e a congolesa.

Em um artigo publicado em meados dos anos 80, Thornton buscou renovar a interpretação sobre a relação entre portugueses e congoleses nos séculos XVI e XVII. ${ }^{59}$ A ideia de dominação dos europeus sobre africanos, baseada numa superioridade de poderio econômico, técnico e bélico que mais tarde culminaria na colonização foi recorrente em trabalhos publicados anteriormente à década de 1970. Esses enxergaram todo o período anterior à ocupação colonial na África iniciada no século XIX pela lógica do declínio (como vimos em Balandier). Thornton utilizou as fontes sobre o Congo para combater essa ideia. Ele chama atenção para o equilibrio entre o reino do Congo do século XVI e Portugal. Através do estudo de vasto corpus documental concluiu que sob os aspectos econômico, demográficos, das técnicas, da organização de poder, entre outros, o Congo foi muito semelhante, se não superior a Portugal durante o período que vai até meados do século XVII. Do ponto de vista cultural, que nos interessa aqui, a cristianização e a incorporação do vocabulário da realeza portuguesa ocorreu tão naturalmente no Congo, para ele, pois no tocante à mentalidade religiosa, complexidade da organização social e hierarquia política, o reino do Congo também era muito semelhante a uma sociedade de antigo regime europeia. Por isso afirma que não se pode transportar os termos de uma situação colonial, característica da relação pósindustrial entre Europa e África para o período anterior. Mesmo em termos culturais.

Na interpretação de Thornton, o Congo para um observador europeu, assim como um português para um observador congolês eram muito menos exóticos culturalmente, economicamente e na organização de poder do que a maior parte da historiografia assume. Desta forma, o historiador muda a perspectiva da alteridade para a semelhança, da tradução para incorporação. Movimento que ocorreu e só foi possível, na minha concepção, graça à recusa do uso do instrumental antropológico pelo autor.

Trazendo à tona a discussão anterior sobre o uso do material antropológico (principalmente dos estudos de MacGaffey) para os estudos históricos dos contatos entre culturas, podemos apresentar os termos tradução e crioulização como conceitos opostos por definição. As traduções simplesmente tornam inteligíveis um determinado

59Thornton, J K. Early Kongo Portuguese relations: a new interpretation. History in Africa. V 8. New Jersey. African Studies Assiciation, 1981, p.183-204. Mas semelhante ideia aparece em todos os seus trabalhos posteriores. 
elemento, ou um conjunto deles, de um sistema ao outro sem transformá-los. A crioulização, do ponto de vista linguístico, consiste no nascimento de um novo idioma baseado em dois, ou mais, sistemas diferentes que são diluídos, perdendo seus sentidos originais em favor de algo novo. Defendemos aqui que resultados tão diferentes foram alcançados pelas tradições historiográficas sobre o reino do Congo porque os estudiosos optaram por diferentes atitudes metodológicas.

No processo de um trabalho histórico sobre sociedades africanas do período "pré-colonial", buscando um estatuto de historicidade, enfrenta-se muitas dificuldades de diferentes naturezas: escassez e unilateralidade das fontes, questões teóricas, metodológicas, entre outras. A historiografia analisada sobre o Congo respondeu a tais dificuldades de maneiras particulares e obteve resultados igualmente particulares e muito ricos, trazendo à tona discussões de enorme importância. Desta forma vem contribuindo muito para o processo de construção do campo da história africanista e para o ofício do historiador de maneira geral.

Dialogaremos com cada uma das posturas teórico-metodológicas a partir dos capítulos seguintes, principalmente os terceiro e quarto capítulos, que tratarão com mais afinco dos elementos católicos propriamente ditos. 


\section{Capítulo 2: Negócio e Fé: Missão Católica e Tráfico de Escravos}

O presente capítulo abordará mais diretamente as fontes históricas. Por ser o primeiro momento que abordaremos os documentos nesta dissertação, o faremos de maneira mais crítica e minuciosa, para que possamos compreender as intencionalidades dos agentes históricos envolvidos na produção dessa documentação e evidenciar os interesses que envolviam esses atores. Por isso, enfocaremos mais a incorporação dos elementos católicos na lógica local nos dois próximos capítulos. Nosso objeto aqui será o projeto missionário do qual fizeram parte os religiosos autores dos documentos e a relação deste com o comércio de escravos no Congo da segunda metade do século XVIII. Será central o questionamento sobre o papel dos agentes do império português de diversas origens. Por isso, este capítulo não privilegiará uma visão interna ao Congo, o que faremos nos seguintes, mas a questão central será a relação entre Congo e Luanda, que nos mostra vinculações entre catolicismo, missão e tráfico de africanos escravizados na segunda metade do século XVIII.

Para contextualização do sistema comercial congolês utilizaremos o trabalho da historiadora norte-americana Susan Herlin Broadhead, principal estudo dedicado especificamente ao período, que contempla habilmente a conjuntura econômica da costa congolesa no contexto de fragmentação política e econômica. ${ }^{60}$ Este trabalho será uma importante ferramenta para compreendermos a centralidade da questão comercial nas fontes disponíveis sobre o período. Utilizaremos também importantes trabalhos de Thornton, que apesar de não tratarem diretamente sobre nosso período nos oferecem (devido à profundidade pela qual tratou dos temas) elementos para compreendermos as complexas redes comerciais.

\footnotetext{
60 Broadhead, Susan H. Trade and Politics on the Congo coast; e Beyond Decline: The Kingdom of the Kongo in the Eighteenth and Nineteenth Centuries, p. 615-650.
} 


\section{1: Fragmentação econômica e trafico de escravos}

A história do reino do Congo no Século XVI e XVII, bastante explorada pela historiografia, como apresentamos anteriormente, foi um período de intensa relação com europeus: missionários católicos e mercadores de escravos na costa congolesa. Desde o reinado de Afonso I, iniciado em 1509 até a morte do rei de Garcia II em 1641, a política congolesa foi marcado por forte centralização do poder, incentivo na adoção do cristianismo e de outras características culturais europeias, e no campo econômico por intenso comércio de africanos escravizados com mercadores portugueses na costa. Esses fatores, juntamente com o estrito controle sobre as rotas de escravos pelos reis congoleses do período permitiu que fosse estabelecida uma parceria comercial sólida entre Portugal e Congo, bastante lucrativa para ambos os reis. ${ }^{61}$

Como observamos na introdução deste trabalho, em meados do século XVII instaurou-se uma crise política no Congo e o poder do rei Garcia II se encontrava ameaçado, sobretudo por razões internas, como conflitos com rivais da importante província de Soyo. Além das turbulências internas havia também forte ameaça externa dos portugueses, que através da conquista de Angola partiram para hostilidades militares nos territórios vizinhos, principalmente aqueles que na época apoiavam os holandeses que ameaçavam as conquistas portuguesas na África. Esse contexto de turbulências internas e externas culminou em guerra no ano de 1665, na qual o exército do Congo enfrentou o grupo pró-português na estratégica região de Ambuila, no vale do rio Ulanga. Foi uma batalha de enormes proporções; missionários que presenciaram a batalha estimaram que quase cem mil congoleses lutaram, em relativa igualdade numérica com o exército pró-português. Apesar dessa igualdade, o exercito português era mais bem preparado e organizado (principalmente devido à presença massiva de Imbangalas, guerreiros profissionais contratados) e a derrota congolesa foi contundente e traumática, contabilizando centenas de membros da elite e o próprio rei do Congo Antônio I como mortos. Após a guerra, as disputas sucessórias internas ao Congo,

\footnotetext{
${ }^{61}$ Havia já desde meados do século XVI a presença de mercadores franceses, ingleses e holandeses, mas sua atividade ganhou volume em relação à lusa a partir de meados do século XVII.
} 
comandadas pela província de Soyo, entre outras, foram acirradas e se iniciou um intenso processo de desorganização política e econômica. ${ }^{62}$

A crise ocorrida após a batalha em Ambuila contribuiu para o enfraquecimento do poder central ligado ao Mani Congo e à corte congolesa e possibilitou a ascensão dos poderes locais, causando intensa fragmentação comercial. Membros das elites das províncias que antes não participavam autonomamente do comércio de escravos passaram a controlar rotas que levavam menor volume de mercadorias do interior para a costa e a venda dos escravizados para mercadores nos portos mais próximos, tornandose assim novos alicerces do tráfico de escravos, realizado, sobretudo com holandeses, ingleses e franceses, que aproveitando a tendência à fragmentação dominaram comercialmente a costa congolesa se aliando diretamente com pequenas chefaturas. A fragmentação desse comércio também ocorria nos interiores, nas rotas que conectavam os mercados de escravos aos portos na costa, por onde passavam as caravanas. Os mercados no interior tornaram-se grandes pontos de comércio, não só de escravos, como de outros bens. Susan Broadhead afirma que este comércio e as saídas de caravanas para a costa eram estritamente geridos pelos chefes locais, o que oferecia grande fonte de legitimidade aos mesmos. O tráfico proporcionava às elites mais do que controle sobre os bens, pois também possibilitava alargar suas conexões, realizar novas alianças, ter mais esposas e filhos. Ou seja, capacidade de agregar cada vez mais pessoas numa relação de dependência, principal fonte de legitimidade e poder no sistema sóciopolítico congolês. ${ }^{63}$

A busca por legitimação dessa elite e o intenso controle local sobre as feiras e caravanas fez da segunda metade do século XVIII um período de absoluto controle africano sobre a escravização e venda de cativos no reino do Congo. Poucos europeus conseguiram ir além dos fortes no litoral, exceção feita aos entornos de Luanda, onde Portugal controlava mais diretamente as rotas de escravos através de alianças com chefes locais, muitas vezes com a participação de mestiços europeizados. 64

\footnotetext{
62 Thornton, John K. The Kingdom of Kongo. Civil war and transition. 1641-1718. Winsconsin press. 1983, p. 69-83. E: The origins and early History of the Kingdom of Kongo, 1350-1550. International Journal of African Historical Studies, V34. Cambridge, Cambridge Univ. Press, 2001, p. 89-120.

${ }^{63}$ Broadhead, Susan H. Trade and Politics on the Congo coast, p.47.

${ }^{64}$ Broadhead, Susan H. Trade and Politics on the Congo coast, p.37-50.
} 


\section{2: Comércio de escravizados na costa congolesa}

Se a participação portuguesa nos interiores era muito bastante, sua hegemonia comercial na costa ao norte do rio Loge também fora muitíssimo enfraquecida. Os comerciantes holandeses, ingleses e franceses já dominavam comércio atlântico e negociavam diretamente com os chefes locais, o que proporcionava às elites centroafricanas total independência dos mercadores portugueses de Luanda, antes hegemônicos. Negociar com portugueses já não era tão interessante para as elites locais congolesas, uma vez que seus produtos eram mais caros (devido às taxações sofridas pelas autoridades de Luanda) e considerados de menor valor para os africanos, uma vez que ingleses e holandeses possuíam acesso a produtos (tecidos, armas de fogo e itens de luxo em geral) muito mais valorizados pelos africanos do que os produtos lusos.

Além de produtos pouco atrativos, os agentes do império lusitano em Luanda tornaram-se gradativamente uma ameaça à hegemonia das elites congolesas sobre seu território e sobre o comércio, o que ocorreu ao longo do processo de seu estabelecimento colonial na África centro-ocidental. Esta inimizade foi gradativamente dando o tom das relações entre S. Salvador e Luanda e alcançou seu auge em meados do século XVII, primeiramente com a política agressiva do governador de Angola João Correa de Souza (1621-1624), que coincidia com a cada vez mais constante presença de mercadores holandeses (mais tarte também ingleses e franceses) como parceiros estratégicos do Mani Congo e elites locais. Isso culminou no apoio congolês à invasão holandesa à Luanda e entrepostos comerciais e militares lusos nos interiores da região em 1641. Após a retomada de Luanda as relações entre Congo e Luanda encontravamse estremecidas ${ }^{65}$

Conflitos políticos internos somados ao interesse de dominação portuguesa acarretaram na batalha de Ambuíla em 1665 no sudeste do reino do Congo. Esta batalha traumática, que teve consequências para a organização política congolesa, determinou o

\footnotetext{
65 Mosterman, Andrea e Thornton, John K. A Re-interpretation of the Kongo-Portuguese War of 1622 According to New Documentary Evidence. Journal of African History, n 51. Cambridge, Cambridge University Press, 2010, p.236-242.
} 
fim das parcerias comerciais significativas entre lusos e congoleses, exceção feita a empreendimentos de pequenos chefes locais.

Os holandeses, ingleses e franceses supriam as demandas por produtos das elites congolesas e a desestruturação política, que gerava muitas guerras civis, abasteciam os navios destes nos portos de Ambriz, Mpinda, Cabinda, Malemba e Loango ${ }^{66}$. Havia ainda rotas ao sul do Congo que vendiam para Luanda (sobretudo no início do XVIII), mas ao longo dos setecentos estas rotas se enfraqueceram. Os portugueses, afroportugueses, luandenses e brasilicos passaram a receber uma fatia pequena do comércio humano e em geral remessas de escravos que não interessavam aos seus concorrentes, tidos como menos valiosos ${ }^{67}$. Esses escravos chegavam à Luanda por rotas que atingiam o vale do rio Nkisi, no interior do reino. Segundo Frei Raimundo, também eram vendidos em Ambuila, ou ao sul em outros territórios vassalos de Portugal. Este trato era feiro principalmente por mercadores originário da província de Quibango, para os mercadores lusos, recebendo em troca panos e ferramentas. Os mbambenses também vendiam aos lançados lusos em troca sobretudo de conchas nzimbu, usadas como moeda no Congo ${ }^{68}$.

Até o início do século XVIII havia também uma rota que descia diretamente de Mbamba à Luanda e outra que atingia o porto na foz do rio Loge, no porto de Ambriz e por mar atingia o porto de Luanda, porém nas ultimas décadas setecentistas o porto de Ambriz parecia dominada por ingleses, sem grandes atividades significativas lusas ${ }^{69}$.

Eram três as principais regiões portuárias no Congo, pelas quais escoavam escravos na segunda parte do século XVIII. O porto de Ambriz, na foz do rio Loge,

\footnotetext{
${ }^{66}$ Broadhead, Susan H. Trade and Politics on the Congo coast, p.53-72.
}

\footnotetext{
${ }^{67}$ Frei Raimundo observou: “Os de Bamba fazem o seu negócio com os Ingleses no porto do Rio Loge, no marquesado do Mussulo, e vendem os escravos por espingardas, louças, pólvora e panos. Dos de Chibango, alguns vendem os escravos em Ambuela e outros sítios da Conquista de Portugal, mas para receber só aguardente, enxadas e alguns bons tecidos, mas a maior parte e os melhores escravos vendem-nos aos Ingleses e para Luanda levam apenas os que os Ingleses não querem, como sejam os homens de idade, as mulheres que já deram à luz por diversas vezes e os meninos pequenos, e o mesmo fazem os de Bamba, para receber dos Senhores Portugueses o zimbo, que é o dinheiro deles". Correa, Arlindo. Informação o reino do Congo por Raimundo Dicomano (...), p12. Essa mesma reclamação é constante na correspondência entre Luanda e S. Salvador ao longo da segunda metade do século XVIII.

${ }^{68}$ Correa, Arlindo. Informação o reino do Congo por Raimundo Dicomano (...), p12.

${ }^{69}$ Thornton, John. The Kongolese Saint Anthony. Dona Beatriz Kimpa Vita and the Anthonian moviment, p.100-104.
} 
encontrava-se entre duas províncias: Mbamba ao norte (importante território político do reino) ao e Mossul (província bastante autônoma) ao sul. Este era o porto ao sul do Congo, mais próximo à Luanda, por isso, foi muito ambicionado pelo império português, região alvo de constantes conflitos. De 1752 a 1800 a hegemonia comercial inglesa em Ambriz foi absoluta, com aproximadamente doze mil escravos adquiridos frente a menos de quatro mil pelos franceses. Para os navios de bandeira lusa (incluindo brasílicos e "angolanos") a cifra não era significativa, ao ponto de não aparecer na base de dados, apesar de ser provável haver algum comércio informal ou clandestino. ${ }^{70}$

A província (politicamente autônoma) de Soyo controlava o importante porto de Mpinda, na foz do caudaloso rio Congo. Este foi o mais antigo entreposto comercial congolês, no qual aportaram os primeiros navios portugueses ainda em 1483. Este porto era rigorosamente controlado pelas elites de Soyo. Apesar de não haver dados na base de dados Slave Voyages sobre este porto no período sabemos que a presença inglesa e holandesa era massiva, com participação significativa também dos franceses. Os escravos vendidos em Soyo tinham duas origens principais. Primeiramente de guerras feitas por próprios membros da elite provincial, principalmente em períodos de instabilidade política. Mesmo não sendo desde meados do século XVII sujeito ao Congo, tampouco disputar a coroa congolesa, as elites de Soyo continuavam muito ativas na política interna congolesa. O apoio militar de Soyo era essencial para a consolidação de facções no poder durante períodos de rivalidades, portanto, as guerras civis no Congo alimentavam a venda de escravizados no porto de Mpinda. Porém, na segunda metade do século XVIII, por ser um período de pouca ação militar em Soyo a demanda era suprida por caravanas vindas do interior comandadas por mercadores mobiri (ou vilis), que poderiam realizar toda a rota do interior ao litoral ou simplesmente agirem como intermediários comprando escravos em S. Salvador, ou Nsundi e venderem aos europeus deixando, obviamente, uma fatia ao soberano de Soyo. $^{71}$

\footnotetext{
${ }^{70}$ As informações quantitativas do trafico de africanos escravizados encontram-se na monumental base de dados Slave Voyages do Du Bois institute, Harvard University, onde é possível descriminar cada um dos portos da costa congolesa, cruzar dados com portos de desembarque e com a nacionalidade dos navios em questão, assim como o perfil dos homens e mulheres escravizados e embarcados nos diversos portos da África dos séculos XV ao XIX. Online em: www.slavevoyages.org.

${ }^{71}$ Correa, Arlindo. Informação o reino do Congo por Raimundo Dicomano, p.12.
} 
Os vilis ou mobires foram personagens importantes da história congolesa durante todo o século XVIII (e mesmo períodos anteriores). Originários de Loango, ao norte do rio Zaire, eram falantes de kikongo e culturalmente aparentados aos congoleses. Fontes portuguesas apontam para o grande poderio econômico e hegemonia comercial do Maloango (soberano de Loango) e sues súditos desde o século XVI, é provável que sua atuação seja ainda anterior. A partir de meados do século XVII, os Vili tornaram-se os principais agentes comerciais nos interiores do Congo, ligando grandes feiras no interior, como de "Malemba pool" aos portos da região do Zaire (em Soyo, Kakongo, Ngoyo e Cabinda). Negociavam tecidos de palma, manilhas, marfim e monopolizavam a fundição do ferro e o transporte de cobre para o litoral. Foram gradativamente, ao longo do século XVII, dominando as rotas de escravizados, ao norte do Congo. ${ }^{72}$

Os vilis, em geral, não eram batizados e pareciam apresentar pouco interesse em tornarem-se cristãos, por não serem incorporados às estruturas sociais e políticas e constantemente e por errarem pelo território ${ }^{73}$. Apesar disso há evidências de que estes estiveram presentes em S. Salvador, desde a restauração por Nessamo a Mbandu em 1709 e foram importantes alicerces econômicos na retomada da capital. Mas desde antes da desorganização política do Congo, já havia vilis atuando em S. Salvador. Em geral, eram ligados às sociedades Lemba, que assim como os kimpassis congoleses, eram associações rituais secretas e iniciáticas. Os rituais Lemba eram essenciais para a prática cotidiana do trato de seres humanos por ser uma atividade que causava grandes desequilibrios entre as forças deste e do outro mundo, por isso, este comércio deveria ser ritualizada de maneira muito específica e especializada ${ }^{74}$ Além disso, segundo Jill Dias, a sociedades iniciáticas Lemba cumpriam também papel importante na regulação do comércio e como ferramenta de garantir a segurança nas rotas. ${ }^{75}$

\footnotetext{
${ }^{72}$ Dias, Jill R. Novas identidades africanas em Angola no contexto do comércio atlântico. In: Bastos, Cristina; Almeira, Miguel e Feldmer-Bianco, Bela (orgs). Trânsitos Coloniais. Diálogos Críticos LusoBrasileiros. Campinas, Ed. Unicamp, 2009, p. 318-326.

${ }^{73}$ Thornton, John. The Kongolese Saint Anthony. Dona Beatriz Kimpa Vita and the Anthonian movement, p.100-104.

${ }^{74}$ Thornton, John. The Kongolese Saint Anthony. Dona Beatriz Kimpa Vita and the Anthonian movement, p.102-103.

${ }^{75}$ Dias, Jill R. Novas identidades africanas em Angola no contexto do comércio atlântico, p. 321.
} 
Observamos que os vilis realizavam atividades no porto de Mpinda em Soyo, porém seus portos privilegiados estavam ao norte da foz do rio Congo, na região de seus estados de origem. Ali os principais portos nos quais eram negociados escravos eram (do norte para o sul) Loango, Malembo e Cabinda. Estes três portos exportaram, na segunda metade do século XVIII, no total mais de duzentos mil africanos para as Américas. Deste número, mais de $70 \%$ foi transportado por navios de bandeira francesa, $14 \%$ por embarcações inglesas, $13 \%$ holandesas e menos de $1 \%$ embarcações com a bandeira do império português. ${ }^{76}$ Segundo Frei Raimundo, os produtos pedidos nos portos ao norte do Congo, em troca de escravos, eram sobretudo tecidos, pólvora, ferro, enxadas, entre outros. ${ }^{77}$

Como observamos, os portugueses eram meros coadjuvantes no lucrativo sistema de captura, transporte e comércio atlântico de africanos escravizados que articulava o reino do Congo e outros pequenos estados vizinhos ao sul durante o século XVIII. Frente a tal situação, os lusitanos tentaram reverter a desvantagem comercial através do domínio militar. A partir de meados da década de 1770 partiram para uma ofensiva rumo ao norte de Luanda, incluído o sul do reino do Congo, objetivando controlar o comércio de escravos e impedir a venda de cativos para seus concorrentes europeus na região de Cabinda e nas embocaduras dos principais rios congoleses: Ambriz e Congo. Mas a estratégia de construir fortes nessas regiões não funcionava como nos territórios ambundos, nos quais Portugal dispunha de reinos avassalados. A tentativa de obter exclusividade na compra de escravos desagradava às elites locais da costa congolesa, que recusavam abrir mão das lucrativas parcerias com outros comerciantes europeus. ${ }^{78}$

Os portugueses de Luanda encontravam-se impossibilitados de realizar alianças locais e utilizavam a guerra como tentativa de dominar à força esse comércio. Apesar de possuírem forte poder de ataque, muitos mosquetes e um numeroso e profissional exército, composto principalmente por povos ambundos (aliados, contratados ou subjugados), Portugal não possuía estrutura para se estabelecer nas regiões. Pouco

\footnotetext{
${ }^{76}$ Base de dados do tráfico de africanos escravizados da W.E.B. Du Bois, disponível eletronicamente em www.s lavevoyages.org

${ }^{77}$ Correa, Arlindo. Informação o reino do Congo por Raimundo Dicomano (...), p. 12.

${ }^{78}$ Broadhead, S. Beyond Decline (...), p. 615- 650.
} 
tempo após as vitórias, "seus" soldados se retiravam dos locais dominados deixando lá poucos oficiais portugueses. Conhecendo bem essa fragilidade portuguesa, os congoleses e sociedades vizinhas evitavam os confrontos militares, deixando que os territórios fossem dominados e aguardando pela retirada da massa de soldados africanos para contra-atacarem. Desta forma, a falta de alianças locais impossibilitava a longevidade das instalações portuguesas, que em pouco tempo se encontravam isoladas, sem capacidade de resistir às constantes hostilidades. ${ }^{79}$

Além dos conflitos locais com congoleses e outros pequenos estados, os portugueses também travaram batalhas diplomáticas contra seus concorrentes europeus no tráfico atlântico. A tentativa da Coroa portuguesa de reassumir a hegemonia comercial na foz do rio Congo desagradou às demais Coroas europeias, que tinham ali grande fonte de renda. Em uma das ocasiões de confronto, os portugueses tentaram obstruir o comércio entre os franceses e os reinos de Ngoyo, Loango e Malimba, na região de Cabinda, e construir um forte na região.

Os franceses, vendo seus negócios ameaçados, enviaram uma expedição comandada pelo prestigiado almirante Marighy e após longas negociações, envolvendo as nações europeias e as elites locais de Cabinda, os portugueses se viram obrigados a abandonar o território em junho de 1784, antes do fim da construção do forte. Algo semelhante ocorreu no ano de 1791 quando os portugueses iniciaram a construção do tão almejado forte na embocadura do rio Ambriz, um dos principais rios do Congo, essencial para escoamento de cativos para a costa, atacando também a província de Mossul, na época importante parceira de mercadores ingleses. Houve, em contrapartida, forte pressão diplomática inglesa, feita diretamente de Londres sobre Lisboa, que fez com que D. Maria, Rainha de Portugal, ordenasse aos militares angolanos que demolissem o forte e abandonassem a região. ${ }^{80}$

A tensão entre Congo e Luanda era tamanha, que portugueses, ambundos ou luso-ambundos correriam grande risco de vida se adentrassem o território congolês sem autorização dos soberanos locais ou do rei, exceto se acompanhados por um padre, como nos relatou frei Rafael:

\footnotetext{
${ }^{79}$ Broadhead, S. Beyond Decline (...), p. 615- 650.

${ }^{80}$ Broadhead, Susan H. Trade and Politics on the Congo coast, p.114.
} 
(...) porque os brancos sós não poderiam viajar por estas terras de pretos [exceto talvez província de Ambuíla], sem um grande perigo, que o Padre os poderia guardar pelo respeito, que nos têm, e Deus mesmo assim o permitiria para acudir àqueles Cristãos, como fiz ainda que ao princípio, e ainda até o fim, com muitos trabalhos. ${ }^{81}$

Essa hostilidade era assumida; os congoleses alertavam luandenses e o próprio padre da interdição: "como eles [congoleses] diziam, aos brancos, que lhe não seria fácil passarem pelas suas terras em salvo, se não fosse o Padre”. ${ }^{82}$

No caso do "império" do Congo e da província de Soyo, os holandeses foram parceiros decisivos e esta parceria faz-se essencial para compreendermos a relação tensa entre Congo e Luanda. Em artigo recente, escrito em conjunto por Thornton e a historiadora holandesa Andrea Mosterman, são apresentadas novas evidencias, presentes em fontes de arquivos holandeses, que apontam para uma profunda relação diplomática entre congo e a Companhia das Índias Ocidentais. ${ }^{83}$ Tratamos há pouco da política hostil ao Congo (entre outras sociedades) inaugurada pelo governador de Angola Correa de Sousa, que buscava ampliar o trato de escravizados através das guerras e dominação, ao contrário da política de alianças feita até então. Este foi um momento decisivo no qual as elites do Congo notaram que os portugueses inegavelmente apresentavam ameaça à estabilidade de seu reino. As ameaças se concretizaram numa batalha na região de Mbumbi, na extensa província de Mbamba, invadida pelo exército a serviço de Luanda, composto em sua maioria por guerreiros Imbangalas. ${ }^{84}$ Como consequência houve terríveis saques e escravização de muitos congoleses na região, embarcados para a América portuguesa pelo porto de Luanda. A derrota congolesa nesta batalha alimentou o sentimento anti-lusitano e algum tempo após a derrota o exército do Mani Congo, com grande apoio de Soyo, recuperou a região e expulsou os portugueses. Neste contexto de revanche, o Mani Congo Necanga a Mbica (Pedro II) e o chefe de Soyo D. Antônio enviaram correspondência para autoridades flamengas através de mercadores de escravos, na qual propunham uma

\footnotetext{
81 Frei Rafael Castello de vide. Viagem e missão no Congo, p. 263-264.

82 Frei Rafael Castello de vide. Viagem e missão no Congo, p. 267.

${ }^{83}$ Mosterman, Andrea e Thornton, John K. A Re-interpretation of the Kongo, p.236-245.

${ }^{84}$ Mosterman, Andrea e Thornton, John K. A Re-interpretation of the Kongo, p. 236-248.
} 
aliança militar contra os portugueses. As elites congolesas garantiriam assim sua soberania e os holandeses por sua vez encontrariam oportunidade de expandir seu negócio escravista. A carta do rei Necanga a Mbica teria proposto o plano de ataque e ocupação de Luanda pela aliança congo-flamenga. Enquanto o exército congolês atacaria por terra, os holandeses lançariam ataques pelo mar. Além da aliança com os holandeses Pedro II buscou apoio do Vaticano, reclamando ao papa sobre a política moralmente duvidosa dos portugueses e reclamou ao então rei de Portugal (e Espanha) Felipe III. Como resultado dessas articulações diplomáticas, a questão chegou ao Conselho Ultramarino português, que julgou o caso e decidiu pelo retorno de cinquenta e três membros da elite de Mbamba, que se encontravam escravizados na América portuguesa, dentre eles a prima do Mani Mbamba. Segundo Thornton e Mosterman, nos anos seguintes mais de mil mbambenses foram enviados de volta à terra natal. ${ }^{85}$

Os planos do ataque Congo-holandês à Luanda esfriaram com a morte de Pedro II, seu idealizador, em 1624 e com a queda do governador Correa de Sousa e uma política mais diplomática em relação ao Congo pelo novo governador Simão de Mascarenhas, intimidado pelo comprovado poder diplomático do Congo no contexto internacional. Esse projeto, porém, se concretizou no ano de 1641, quando de fato, com assistência congolesa, os holandeses invadiram e ocuparam Luanda, assim como outros entrepostos portugueses. O período holandês em Luanda (1641-1648) foi responsável por uma aproximação comercial ainda maior entre Congo e Companhia das Índias Ocidentais, que ocupava também Pernambuco, para onde foi enviada uma embaixada do rei do Congo em $1643 .{ }^{86}$

A partir deste período, consolidou-se a parceria com holandeses, que continuou no período de fragmentação e de reunificação, assim como em todo o decorrer do século XVIII. Por isso, não se pode perder de vista a importância dessa aliança, assim como das alianças com franceses e ingleses, para compreendermos a relação entre Congo e Portugal na segunda metade do século XVIII e para compreendermos os bastidores e as motivações que acompanharam a produção de nossas fontes missionárias.

\footnotetext{
${ }^{85}$ Mosterman, Andrea e Thornton, John K. A Re-interpretation of the Kongo, p.242.

${ }^{86}$ Mosterman, Andrea e Thornton, John K. A Re-interpretation of the Kongo, p. 236-242.
} 
Frente ao contexto comercial atlântico da costa congolesa é possível afirmar que o processo de descentralização do poder político e econômico do reino do Congo ocorrido no século XVIII e a intensa fragmentação do controle sobre as rotas de cativos, que dividiu o comércio com concorrentes europeus, trouxe significativos prejuízos à Coroa portuguesa por restringir o acesso ao lucrativo comércio de escravos na costa congolesa. Esse fato é de extrema importância para a compreensão do significado da missão católica e da documentação que será discutida adiante.

\section{3: Interlocutores e intencionalidades nos textos missionários}

O relatório de Frei Rafael Castelo de Vide é o principal e mais extenso documento missionário conhecido que data da segunda metade do século XVIII. de Vide missionou por aproximadamente dez anos no reino do Congo (1779 a 1788) e durante esse período presenciou diversos acontecimentos políticos, foi vigário geral do Congo, habitou na capital e teve relação próxima com os reis do Congo. Além disso, viajou muito para diferentes províncias próximas e afastadas da capital, sempre em contato estreito com as elites locais.

O relatório dos dez anos de missão de Frei Rafael encontra-se montado como um mesmo documento, bastante extenso e organizado cronologicamente na forma de um diário. Mas de fato é composto por quatro diferentes textos, todos eles de autoria do mesmo padre, escritos em datas diferentes e por isso em contextos e com objetivos diferentes. Se nos ativermos ao caráter informativo dessa documentação, não encontraremos muitos elementos para a compreensão das motivações e dos bastidores desse projeto missionário, tampouco sobre a relação da missão com a conjuntura comercial da costa congolesa. Naturalmente, o texto de Frei Rafael é focado em questões religiosas e em seu trabalho catequético, mas havia por detrás dessa intencionalidade e para além das motivações divinas deste projeto uma estrutura institucional que patrocinava a missão e oferecia condições materiais para o sustento dos missionários e da própria liturgia católica. Uma ferramenta que dispomos para acessar essa estrutura oculta à missão é a crítica documental dos relatórios missionários, sobretudo no questionamento acerca da intencionalidade na produção e interlocutores dos textos. O fato de o documento ser composto por quatro diferentes relatórios, 
produzidos e remetidos em diferentes contextos, enriquece as possibilidades de leitura crítica e comparativa interna à fonte.

No primeiro relatório, enviado em 16 de Julho de 1781, de Vide se concentra em seu primeiro ano de missão, fala principalmente sobre a viagem de Portugal à Luanda e de lá para o reino do Congo. O principal interlocutor desse texto aparece explícito no início do relatório: "Ex.mo Ir. Provincial da província de Piedade"87, província franciscana em Portugal a qual Rafael Castelo era ligado. O objetivo central desse primeiro texto é dar satisfações ao seu superior na ordem sobre os progressos da missão: fica claro que o relatório foi escrito sob encomenda do próprio gerente provincial. Nessa primeira relação não aparecem outros interlocutores ou possíveis interessados na leitura do texto diretamente citados e o objetivo parece ser simplesmente dar as primeiras notícias sobre a chegada em Luanda e o estado de sua saúde, sem se aprofundar muito em especificidades das missões ou do território africano.

O segundo texto, escrito pouco mais de um ano após o primeiro, também foi endereçado a seu superior provincial, mas nos informa de outros possíveis interlocutores:

A segunda relação da minha Missão, que faço com os fins nela mencionados; e porque foram outras para o Ex.mo Senhor Bispo e Senhor General, quero igualmente fazer uma para animar meus irmãos, se alguém quiser ocupar-se de tão meritório fim $^{88}$

Esta cópia tem como principal finalidade fazer propaganda da missão para seus “irmãos" missionários e animá-los também a aderir ao trabalho catequético nos interiores da África, em diversas passagens ao logo do texto Rafael explicita a mesma intencionalidade. Nos chama atenção o fato do missionário citar cópias anteriores remetidas à principal autoridade eclesiástica e militar de Luanda, ambos portugueses. Parece possível especularmos que os textos produzidos para a autoridade militar -

\footnotetext{
87 Frei Rafael Castello de vide. Viagem e missão no Congo, p. 267.

${ }^{88} \mathrm{O}$ bis po citado é o de Angola e Congo (cargo nominal mas a diocese era sediada em Angola) Alexandre da Sagrada Família que ocupa o posto em Luanda, e Senhor General trata-se do Capital Geral (ou capitão Mor) maior autoridade militar portuguesa na África que ocupava o posto em Luanda. Seus "irmãos" seriam os missionários franciscanos da mesma província de Piedade. Frei Rafael Castello de vide. Viagem e missão no Congo, p. 107.
} 
Capitão Mor e Governador de Angola - tenham conteúdo diferente da cópia que dispomos, pois para a principal autoridade temporal portuguesa na África os interesses deveriam ir além da expansão da fé e salvação das almas, tratando provavelmente questões estratégicas e comerciais. ${ }^{89}$

Temos outras evidências do interesse por parte dessas duas autoridades por informações pragmáticas sobre a situação congolesa. Em carta enviada pelo mesmo bispo de Angola e Congo: Frei Alexandre da Sagrada Família, para um oficial da Coroa em Lisboa em 1785, é citada a importância e necessidade de receber notícias atualizadas e claras de de Vide sobre o reino do Congo: "Escrevi a Frei Rafael, rogando-lhe que viesse a esta cidade, a fim para me dar em voz as informações que por escrito sempre são escassas e confusas, e pouco úteis(...)", 90 O questionamento quanto à escassez ou pouca utilidade das informações é algo que chama atenção na carta do bispo, pois nos aponta que para esta autoridade religiosa haviam interesses que obviamente transcendiam as questões da fé.

As motivações das autoridades portuguesas ficam ainda mais evidentes no ultimo dos relatórios escrito por Castelo de Vide em 1787, no qual aparece claramente uma intencionalidade diferente em relação aos textos anteriores. Aqui Frei Rafael não cita "seus irmãos" como interlocutores, e tampouco tem como preocupação incentivar o envio de novos missionários. Seu relato é mais frio e pessimista, centrando-se nas dificuldades do seu trabalho e nas condições precárias das missões nos interiores africanos. Nesse relatório, sua narrativa é mais objetiva e enfatiza fatos políticos e questões que envolvem o comercio de escravos. De fato, atende as reivindicações do bispo por informações mais pragmáticas. Vale notar que este texto foi escrito após uma reunião que Frei Rafael teve com o bispo em 1785 em Luanda, e a mudança de seu foco narrativo provavelmente ocorreu por recomendações superiores. Certo rancor sobre a obrigação de dar informações "úteis" aparece no início de seu texto:

Débeis serviços de inútil servo, indignos de se narrarem, e muito menos pela minha própria mão, motivo por que tenho demorado há

\footnotetext{
${ }^{89}$ Infelizmente não temos notícia do paradeiro de outras versões do relatório de de vide além da que dispomos.

${ }^{90}$ Arquivo Histórico Ultramarino, AHU, papéis de angola, cx 70, doc 28. Possuo versão digitalizada. além das transcrições disponibilizadas por Arlindo Correa em: www.arlindocorrea.com.
} 
três anos esta relação, ou também por me parecer não ter mais que dizer, que o que está dito nas relações antecedentes; mas a obediência me obriga, e me constrange com um rigoroso preceito, a que não resisto, mas, com amargura e temor, refiro o que tenho passado (...). ${ }^{91}$

Ainda sobre a questão dos interlocutores e do contexto de produção do documento, é importante tratar do relatório do Frei Capuchinho Raimundo Dicomano, escrito quase uma década mais tarde. Esse relato não nos informa sobre a estrita ligação entre a missão e as autoridades lusas em Luanda, como faz de Vide. Não é um diário de missão, mas um relatório descritivo, subdividido por tópicos que trata basicamente da organização política, social e religiosa congolesa. É difícil, por isso, determinar por onde Frei Raimundo missionou e qual foi sua atuação específica junto à colônia de Angola ou à Coroa portuguesa. Mas se questionarmos a intencionalidade na produção do relatório e de seu interlocutor podemos extrair algumas pistas. Antes, é importante compreendermos a especificidade institucional desse missionário em comparação com Castelo de Vide. Para tal, é essencial tratar brevemente sobre a origem da ordem capuchinha e sua expansão no contexto da política missionária do Vaticano.

Em 1622 foi criada no Vaticano a Sagrada Congregação da Propaganda Fide, com objetivos de renovação e intensificação da missão católica no ultramar. Até então o papado vinha exercendo papel secundário nas missões ultramarinas, pois através do Padroado e Patronato Portugal e Espanha eram os detentores do território e responsáveis pela conversão das almas e manutenção da fé em todas as terras habitadas por "gentios". Apesar de controlarem apenas o clero secular, as Coroas ibéricas, sobretudo Portugal, tinha outro "braço" importante: a Companhia de Jesus. No início a meados do século XVI nasce o conceito de "poder indireto" ligado a uma tradição teológica formulada inicialmente por Francisco de Vitória, seguido por outros doutores da igreja como Francisco Suárez e Manuel da Nóbrega. Esses importantes teólogos chamavam atenção para a necessidade de um projeto de conversão e tutela das populações indígenas das terras recém-conquistadas, que seria responsável pela propagação da fé e salvação dessas almas gentílicas. Nesse contexto o aparato colonial português e seu clero secular perdem importância e essa tutela é concedida pela Coroa e pelo papado à Companhia de Jesus, que não controlava apenas a conversão como a administração dos gentios. Há,

\footnotetext{
${ }^{91}$ Frei Rafael Castello de vide. Viagem e missão no Congo, p. 229.
} 
portanto, uma estreita ligação entre o projeto colonial português de expansão da fé e manutenção dos territórios ultramarinos e a Companhia de Jesus.

Observando esse contexto nota-se que a criação da Propaganda Fide (propagação da fé) significou uma virada na política eclesiástica e missionária do papado, que buscou controle mais direto das missões retirando o monopólio que Portugal (legitimado pelo Padroado) e que a Companhia de Jesus exerciam, inclusive nos territórios não conquistados, como o Congo.

A criação da Prefeitura Apostólica do Congo, em 1640 pelo papa Urbano VIII, também foi sintomática desse movimento. ${ }^{92}$ A Propaganda Fide era diretamente ligada ao papado, que incentivava principalmente as atividades da ordem dos Frades Menores Capuchinhos, que tinha em sua significativa maioria religiosos italianos. Desta forma os capuchinhos conquistaram rapidamente a hegemonia das missões no Congo, rivalizando com os jesuítas portugueses, que cada vez mais se restringiam às conquistas nos entornos de Luanda. ${ }^{93}$

Para além da perspectiva europeia, houve também agência importante dos congoleses neste processo de "virada" da política eclesiástica, iniciada no reinado do Mani Congo Alvaro III, que enfrentava rivalidades internas, e simultaneamente buscava defender-se da política de crescente ofensiva do governador de Angola João Correa de Sousa, que inaugurou uma política inédita que buscava dominar comercialmente a região através de guerras e ocupações. Neste quadro de crescentes tensões, o bispo do Congo e Angola Simão Mascarenhas abandonou a então sede do bispado em S. Salvador, partindo para Luanda em 1619. A atuação deste prelado evidenciou o vinculo do bispado com interesses econômicos dos portugueses.

O rei Alvaro III foi sucedido por Pedro II, hábil negociador, que antevendo o risco da agressiva política externa luandense trocou correspondências com o papa,

\footnotetext{
92 A propaganda Fide organizava os territórios em "prefeituras", sempre um dos missionários das expedições é o prefeito, autoridade maior nomeada e subordinada diretamente ao papa: Thornton J. K. The development of an african Catholic Church in the Kingdom of Kongo, 1491-1750. The jornal of African History. Cambridge, Cambridge Univ. Press, p. 147-167.

${ }^{93}$ Gonçalves, Rosana A. África Indômita. Missionários Capuchinhos no Reino do Congo (século XVII). Dissertação de mestrado em História Social. Universidade de São Paulo. São Paulo, 2008, p.56-65. Trabalho esclarecedor para compreensão da especificidade da missão capuchinha e a relação estreita dessa ordem com o reino do Congo.
} 
demonstrando o descontentamento com a administração eclesiástica portuguesa e empenhando-se em uma relação mais direta com Roma, sugerindo inclusive que substituísse o bispo "fujão" por Brás Correa, um religioso da confiança do Mani Congo, que desejava que o Congo tivesse um bispado próprio. As criticas de D. Pedro II Necanga a Mbica podem ser entendidas, num escopo mais amplo, como críticas ao próprio direito estabelecido pelo Padroado e deve ser levada em conta no processo de transformação da política missionária europeia no período. ${ }^{94}$

O pedido do Mani Congo por um bispado próprio não foi atendido, mas de certo modo, a criação da congregação da Propaganda Fide e a consequente presença de capuchinhos italianos convergiram com os interesses das elites do Congo. Os soberanos seguintes, ao longo do século XVII passaram a ter nos religiosos capuchinhos italianos elementos importantes de defesa de sua soberania frente à Luanda e na abertura de canais de comunicação diretos com o papado. ${ }^{95}$ Debateremos no final deste capítulo, de maneira mais profunda, as relações entre Congo e a Companhia da Índias Ocidentais e a importância desta parceria para a relação conflituosa entre Congo e Luanda. Veremos na ocasião que a intencionalidade congolesa ia além da simples defesa de seu território e do controle religioso; era bastante mais ambiciosa do que pode parecer a priori.

Observando o contexto das missões capuchinhas do século XVII, seria possível supor que Frei Raimundo, por ser um capuchinho, não estivesse institucionalmente vinculado às autoridades portuguesas. Porém, ao investigarmos os propósitos da produção de seu relatório e seu principal interlocutor observamos que há sim vínculos do missionário com Luanda:

Informação sobre o reino do Congo, apresentada ao II.mo e Ex.mo Senhor D. Miguel António de Melo, governador, e Capitão Mor do Reino de Angola (...) Para satisfazer o pedido, que V. Ex.a me fez de lhe relatar por escrito o que vi e pude saber no decurso de três anos,

\footnotetext{
${ }^{94}$ Mosterman, Andrea e Thornton, John K. A Re-interpretation of the Kongo-Portuguese War, p. 147167. Sobre as disputas políticas internas no Congo: Heywood, Linda e Thornton, John. Central African Creoles and The Foundation of the America, p. 135-143.

${ }^{95}$ Thornton, John K. The Kingdom of Kongo. Civil war and transition, p. 69-83.
} 
que ocupei indignamente o posto de Missionário do Reino do Congo(...). ${ }^{96}$

Seu texto foi remetido ao Capitão Mor e governador de Angola a pedido do mesmo, o que indica que a característica independência de Angola dos Capuchinhos que missionaram no Congo durante o século XVII talvez não se aplique ao contexto fragmentário do século XVIII. Essa evidência, juntamente com as evidências da participação direta nas missões dos administradores coloniais em Angola, contexto apresentado por Frei Rafael, nos sugere que nesse período elas dificilmente se sustentariam sem o apoio da Coroa portuguesa e seus administradores em Luanda.

Há outras evidências que vinculam a missão capuchinha no período com autoridades de Luanda. Em carta enviada em 1785 pelo bispo de Angola Alexandre da Sagrada Família a Martinho de Mello e Castro ao Ministro da Marinha e Negócios do Ultramar são citadas informações recebidas por capuchinhos missionando em Soyo:

Se não são encarecidas as notícias que este Padre me dá, só naquele Reino há alguma coisa de Religião, como também em Sonho, segundo notícias dos Capuchinhos o mais terreno onde os brancos põe os pés, está inteiramente perdido $(\ldots)^{97}$

Podemos supor, baseando-nos na questão da interlocução das fontes, que a missão católica empreendida nas décadas finais do século XVIII era muito diferente daquelas de séculos anteriores no que diz respeito à relação de dependência entre os missionários e a conquista lusa de Angola e em última instância à Coroa portuguesa. Mesmo aqueles missionários europeus de outras nacionalidades e ordens religiosas diretamente ligadas ao papado, como a capuchinha, eram dependentes ou vinculados às autoridades luandenses em algum grau. Autoridades estas, como observaremos, que

\footnotetext{
${ }^{96}$ Correa, Arlindo. Informação o reino do Congo por Raimundo Dicomano, p. 2.

${ }^{97}$ AHU, papéis de angola, cx 70, doc 28. Agradeço ao Prof. Thornton pela concessão de cópias deste documento. Transcrição disponível eletronicamente: Correa, Arlindo. O missionário e o Negócio. 2007, p. 17. http://www.arlindo-correia.com/041207.html
} 
tinham interesses muito específicos na reaproximação com o reino do Congo e muito empenho no projeto missionário.

\section{4: Coroa portuguesa e o financiamento da missão}

A evidência mais direta entre a relação do projeto comercial português com a missão católica no Congo durante a segunda metade do século XVIII aparece na questão do financiamento e preparação da missão, tema recorrente na documentação, principalmente no diário de Frei Rafael e nas cartas entre autoridades portuguesas, angolanas e congolesas.

Logo no início de seu primeiro relatório, Castelo de Vide afirma:

(...) foi esta Missão de grande empenho da Rainha Nossa Senhora, assim para restabelecer a Cristandade, que aqui foi plantada pelos Portugueses, como também para renovar a antiga amizade, que sempre houve entre o Congo e Portugal, e os Reis de um e outro Reino, o que esperamos conseguir pelo grande agrado, que temos encontrado neste Rei do Congo, e nos maiores fidalgos, anuindo a tudo o que se propõe, e esperamos principalmente nele integrar a Cristandade que aqui achamos muito descaída ${ }^{98}$

Adiante:

Tendo a muito Augusta, Pia e Religiosa Rainha de Portugal, Dona Maria Primeira Nossa Senhora, que Deus guarde, mandado convidar toda a hierarquia eclesiástica do seu Reino para ir cultivar a vinha do Senhor, que em seu Estado de Angola se encontrava quase toda dissipada $(\ldots)^{99}$

Fica claro que o projeto de intensificar as missões e de "reerguer" o catolicismo no Congo tinha como incentivadora a Coroa portuguesa na figura da Rainha D. Maria I aparentemente a "cabeça" de todo esse projeto, que vinculava os objetivos "restabelecer

\footnotetext{
${ }^{98}$ Frei Rafael Castello de vide. Viagem e missão no Congo, p. 4.

${ }^{99}$ Frei Rafael Castello de vide. Viagem e missão no Congo, p. 6.
} 
a cristandade" e "renovar a amizade que sempre houve entre e Congo e Portugal". Nessa argumentação, o catolicismo aparece como elemento capaz de restabelecer a decadente parceria entre Portugal e Congo e justificaria o grande empenho da Rainha para tal fim.

D. Maria I, assumiu o trono em 1777 num contexto de volta dos conservadores ao controle do reino português após a "era pombalina" na qual ocorreu forte movimento anti-missionário encabeçado pelo secretario de estado Marquês de Pombal, movido por preceitos do liberalismo e da ilustração, em alta em outras nações europeias na época. A nova rainha portuguesa tinha uma política absolutamente oposta, apresentando forte ímpeto religioso, pelo qual ganhou o nome de 'D. Maria I, a Pia". Realizou, no período, grande incentivo às missões e à ampliação do catolicismo no ultramar. Além das missões D. Maria patrocinou outras diversas medidas em Portugal e nas colônias como a publicação de um catecismo em quimbundo no ano de 1784, com o objetivo de facilitar a conversão e práticas da catequese na região de Angola. ${ }^{100}$

A expedição missionária que Frei Rafael de Vide integrou, atendendo à convocação da soberana portuguesa, levou à África vinte e cinco missionários, pertencentes a diferentes ordens, que partiram de Lisboa no dia 22 de junho de 1779. Acompanhando os religiosos, estava o "Capitao General do Reino de Angola" José Gonçalves de Camara que segundo Fr. Rafael "trazia de nossa Soberana particulares recomendações" e foi personagem ativo na preparação dos religiosos. Após a chegada em Luanda os missionários foram delegados pelo Capitão Mor e o bispo para diferentes localidades, incluindo territórios nos interiores de Angola.

Frei Rafael relata que a comitiva que saiu para o reino do Congo foi a ultima a partir de Luanda, pois era a prioridade do Capitão Mor e da Rainha e por isso deveriam estar mais bem preparados, para atender recomendações específicas das autoridades portuguesas e também melhor financiados pela real fazenda. No dia 8 de Agosto de 1780 partem os quatro missionários: dois franciscanos, um beneditino e aquele que foi o único companheiro de de Vide a sobreviver durante todo o período de seu relato: "Pe. Andre de Couto Godinho, presbítero do hábito de São Pedro, clérigo preto, mas de alma bem branca pelas suas virtudes."101 Pe. Godinho aparece como figura ativa na

\footnotetext{
${ }^{100}$ Vansina, Jan. Portuguese vs Kimbundu : Language Use in the Colony of Angola (1575 -1845). In Bull. Séanc. Acad. r. Sci. Outre-Mer Meded. Zitt. K. Acad. overzeese Wet. 2001, p. 267-281.

${ }^{101}$ Frei Rafael Castello de vide. Viagem e missão no Congo, p. 23.
} 
narração de Frei Rafael, mas sua origem não é discutida pelo padre, infelizmente apenas possuímos notícias sobre esse religioso negro na narrativa de seu companheiro, que não informa sua origem. ${ }^{102}$

Não é possível saber o tamanho da comitiva que acompanhou os padres, mas ela parece ter sido composta por diversos carregadores, condutores e intérpretes, que levavam além dos religiosos muitos suprimentos, presentes e objetos de culto: rosários, hóstias, vinho, imagens de santos, entre outros; tudo isso patrocinado pela fazenda real. $^{103}$

Além das evidências do enorme empenho financeiro da Coroa portuguesa na missão congolesa encontradas no texto de Castelo de Vide, dispomos de uma carta remetida em 1785 pelo bispo Frei Alexandre da Sagrada Família ao rei do Congo D. Afonso $\mathrm{V}$ que, entre outras coisas, pede ao rei que monitore e proteja os padres enquanto esses viajam pelos interiores do reino e trata do alto custo dessas missões. Escreve o bispo:

Mas como nos consta que esta presente estação não é conveniente para viajar pelos sertões, o mesmo desejo de os assegurar a V. Majestade, nos obriga a demorar-lhes a partida, para tempo menos penoso e arriscado. Como o transporte dos outros Padres foi tão cheio de inclamidades, quiséramos que V. Majestade desse com tempo tais providências, que estes segundos possam chegar sem perigo à Corte de V. Majestade. Porque, Senhor, além de ser muito preciosa a vida de um Missionário, principalmente onde há tão poucos, deve-se também atentar a grande despesa que a Rainha Fidelíssima de Portugal, minha graciosíssima Soberana, faz com estes Padres, que the custa cada um acima de setecentos mil reis de moeda Portuguesa(...). ${ }^{104}$

\footnotetext{
102 Pe. Godinho tem sido objeto de estudo recentemente de Lucilene Reginaldo: Reginaldo, Lucilene. Homem preto, natural do Brasil, missionário no Congo: a história de André Couto Godinho e o contexto missionário no Reino do Congo (1779-1788). Anais do XXVI Simpósio Nacional de História. ANPUH. São Paulo, 2011.

${ }^{103}$ Frei Rafael Castello de vide. Viagem e missão no Congo, p 252-253.

104 Arquivo Histórico Ultramarino, AHU, papéis de Angola, cx 70, doc 28. Possuo cópias digitalizadas. Além das transcrições disponibilizadas por Arlindo Correa em: www.arlindocorrea.com.
} 
Nesses setecentos mil réis, provavelmente exagerados, que o bispo afirma "custar" cada missionário, devem estar inclusos os custos gerais da missão, pois de Angola vinha todo o material de culto dos missionários. Problemas referentes a escassez de material religioso são constantes nos relatos. Os padres tiveram sempre a preocupação em buscar ou pedir materiais de Angola e por vezes se viam impedidos de prosseguir os trabalhos sacramentais por carência material. Luanda é claramente o posto de abastecimento da missão.

Os missionários recebiam também pagamento anual de oitenta mil réis da Coroa portuguesa, mesmo que de fato servissem ao rei do Congo. ${ }^{105}$ Tendo em vista esse empenho financeiro e a dependência direta que os missionários e a liturgia católica tinham da Coroa portuguesa, fica mais evidente a vinculação do projeto catequético com interesses temporais de instituições portuguesas. Já os religiosos, independentemente das mais cristianíssimas motivações para o trabalho de catequese, dependiam das autoridades portuguesas sediadas em Luanda (bispo e captião mor) para sua sobrevivência e para realização de seu trabalho diário.

As evidencias apresentadas anteriormente vinculam o projeto de cristianização ou "recristianização" do Congo aos interesses da Coroa Portuguesa na retomada da antiga parceria que portugueses gozavam em épocas de centralização política congolesa no século XVI e início do XVII.

Ao cruzarmos estas evidências com o contexto comercial da costa congolesa na segunda metade do século XVIII apresentadas anteriormente, parece possível afirmar que a disseminação do cristianismo, que se acreditava decadente, era o meio pelo qual os portugueses buscavam retomar a aliança com o rei do Congo. E através da aliança entre os reis do Congo e Portugal, cimentadas pelo catolicismo que compartilhavam, Portugal conseguiria recuperar sua participação no lucrativo comércio de escravos na costa congolesa.

Aceitando essa hipótese como provável, notamos que há outro desafio ainda maior do projeto português além de estabelecer a parceria com o rei do Congo, que como se viu anteriormente tinha seu poder esvaziado. Já observamos que o intenso processo de descentralização do poder político e econômico no Congo prejudicou a participação portuguesa no tráfico de escravos. Por isso, podemos inferir que (na

\footnotetext{
${ }^{105}$ Frei Rafael Castello de vide. Viagem e missão no Congo, p. 223.
} 
perspectiva lusa) não bastava reconstituir a aliança com o rei católico, mas era importante que esse rei tivesse poder suficiente para que a aliança gerasse frutos comerciais para Portugal, ou seja, que esse rei tivesse o maior número de chefes locais submetidos a si.

É evidente que para realizar tal projeto o missionário deveria ter autonomia necessária para decidir a quem prestaria apoio ou que tivesse um grau de autonomia e circulação dentre diferentes facções da política congolesa. Veremos no capítulo terceiro que esta questão é bastante complexa e que a intenção do padre de ser autônomo esbarará no modelo político congolês e na autoridade do Mani Congo. Estas especificidades africanas serão debatidas a posteriori, neste momento nos preocupamos, sobretudo em compreender as intencionalidades dos missionários (e seus mantenedores) para à frente discutir a relação de dependência e conflito entre o missionário e as elites políticas congolesas.

\section{5: D. José I e a reconquista de São Salvador}

Após partirem de Luanda, passando por diversos povoados: mbanzas e libatas de diferentes "ducados"106 Frei Rafael e seus companheiros chegaram à região do rio Ambriz nas chamadas "terras da rainha", que se dividiam em algumas províncias, principalmente as vizinhas Mpemba e Mucondo. Essas eram as terras de origem do então rei D. José I, onde habitavam seus principais aliados e familiares. Ali, os missionários tiveram o primeiro contato com um importante membro da elite desse partido; o Marques de Mpemba D. Afonso de Leão, irmão de D. José I, foi responsável pela recepção dos padres em mbanza Mucondo. Apesar de ser chefe de Mpemba, D. Afonso "assistia" seus irmãos na província vizinha. Na verdade as regiões de Mucondo e Mpemba encontravam-se bastante integradas (sendo difícil determinar suas fronteiras), desde o longo governo nestas províncias da importantíssima soberana Ana Afonso de Leão, que dá nome a região.

\footnotetext{
106 Mbanza é o nome em kikongo para cidades maiores, geralmente as capitais das "províncias" onde residiam os chefes tradicionalmente ligados à linhagem do Mani Congo. Libata são aldeias menores nos interiores das províncias tradicionalmente governadas por chefes de linhagem diferente da do rei. Hilton, Anne. The kingdom of Kongo. Oxford university Press. 1985 p 24. Mbanza Congo era o nome da capital do reino do Congo, que ganhou o nome português de São Salvador. A documentação sempre trata a cidade como São Salvador ou por "corte".
} 
Rainha Ana foi a mais importante figura política da segunda metade do século XVII no Congo, ela possuía o título de Muene Nlaza, título que gozava por ser a chefe maior de sua importante kanda (plural makanda, genericamente significa "linhagem"), que em seu nome teria ganhado o nome de quinlaza. Ela foi de fato rainha, pois era viúva do Mani Congo Afonso II e irmã de outro rei, Garcia II, o ultimo "grande" rei do Congo do século XVII, antes da crise política e descentralização. ${ }^{107}$ Debateremos sobre as makanda e sobre os quinlaza no capítulo seguinte, e sobre o poder feminino e sua importância no capítulo quarto; nestas ocasiões aprofundaremos a importância desta soberana.

$\mathrm{Na}$ chegada à dita mbanza, os missionários foram recebidos por uma grande comitiva com muitos homens armados, instrumentos musicais, danças e cantos descritos como "cantos de Nossa Senhora". Em geral era como os grandes Infantes os recebiam. $^{108}$

Afonso aparece como uma figura muito particular nos relatos de de Vide. Sobre ele o padre escreve:

O irmão mais moço [do rei José I] chamado D. Afonso, em cuja Banza estivemos os três meses, é o mais atencioso, urbano, cortês, que temos encontrado de costumes, e urbanidade de Português; escreve este, e o lê, e entende alguma coisa, de grande estatura, e poderoso, mas humilde e sujeito à Igreja, de que é Mestre, ou Intérprete. ${ }^{109}$

$\mathrm{Na}$ mbanza de Mucondo, os religiosos ficaram três meses. A intenção inicial dos padres era de apenas passarem por ali, descansarem por poucos dias e logo partirem ao encontro da caravana do Rei José I, para finalmente retornarem a São Salvador. O motivo que reteve os padres nessa mbanza foi o fato do Mani Congo se encontrar

\footnotetext{
107 Thornton, John K. Elite women in the kingdom of Kongo: Historical perspectives on women's political power. Journal of African History, 47, Cambridge University Press. 2006. p. 455, 456. Rainha Ana é personagem central no livro de Thornton: The Kongolese Saint Anthony. Dona Beatriz Kimpa Vita and the Anthonian moviment, p. 97-121; Broadhead compartilha da mesma opinião: Broadhead, Suzan H. Beyond Decline.1979.

${ }^{108}$ Infantes é o termo pelo qual a documentação, principalmente Castelo de vide, trata dos principais nobres. Discutiremos especificamente sobre esse sistema de titulação no capítulo seguinte.

${ }^{109}$ Frei Rafael Castello de vide. Viagem e missão no Congo, p. 84.
} 
incapacitado de retornar à Capital. Os membros das elites de Mpemba não permitiram que os padres seguissem viagem, afirmando haver um levante contra o rei, comandado por uma facção rival, e que por isso ainda não era seguro ocupar a capital. $\mathrm{O}$ padre ficou intrigado com a atitude dos partidários de José I, que não ofereciam informações convincentes e pareciam esconder deles a situação política que envolvia o Mani Congo. $^{110}$

Ainda mais desconfiado ficaram os missionários quando apareceu em Mucondo uma carta endereçada aos religiosos, levada por um mensageiro de outra província, escrita por representantes da outra "parcialidade" inimiga de José I. Tal carta dizia que este não era o legítimo Mani Congo, e que seu antecessor Pedro V continuava vivo e reinando na capital, sendo os quinlaza de golpistas. Os padres avaliaram que a carta era muito bem escrita e julgaram conter argumentos consistentes, o que levou Frei Rafael a questionar os descendentes da rainha Ana Muene Nlaza sobre a veracidade dessas informações. Afonso de Leão garantiu-lhes que o Mani Congo Pedro V existiu, mas já havia morrido e que a intenção dos seus inimigos era confundir os missionários para causar desordem política. ${ }^{111}$

A kanda oposta aos quinlaza, que reivindicavam o poder chamava-se quimpanzo. Esses dois partidos rivais, desde a restauração em 1709, se alternavam no poder em S. Salvador. Em geral os reis quimpanzo eram sucedidos por um quinlaza e vice-versa, neste caso (como debateremos no próximo capítulo) há um impasse relativo à sucessão e a presença dos padres sob a tutela dos quinlaza acirrou as tensões, colocando os missionários numa situação complexa, a qual pouco compreendiam. ${ }^{112}$

A carta citada causou grande revolta entre Afonso de Leão e seus aliados, que pretendiam punir seu portador. de Vide foi obrigado a escondê-lo dentro da casa dos padres, que foi cercada pelos furiosos locais em busca do pobre carregador. Conseguiram, então, convence-los a deixar o homem partir ileso e com ele o missionário enviou uma carta em resposta ao partido oposto, apresentando uma postura conciliadora, deixando claro que não apoiava nenhuma das facções e que não pretendia interferir na disputa. Porém salientou que o rei do Congo deveria ser legítimo pela

\footnotetext{
${ }^{110}$ Frei Rafael Castello de vide. Viagem e missão no Congo, p. 72-86.

${ }^{111}$ Frei Rafael Castello de vide. Viagem e missão no Congo, p. 81, 82.

112 Sabemos do sistema de alternância de poder pelo missionário Cherubino de Savona: Toso, Carlo. Relazioni inedite di P.Cherubino C. da Savona (...), p. 207.
} 
justiça e por todo o povo. E que como missionário, teria obrigação de atender a todos, não se envolvendo em "temporalidades". 113

A desconfiança da legitimidade de José I fez com que Pe. André fosse ao encontro do suposto rei, para tentar resolver o impasse. Caso avaliasse que este era o verdadeiro Mani Congo, os missionários apressariam sua entrada em São Salvador para por fim nas tensões entre os dois partidos. Ao encontrar com D. José I e sua comitiva, Pe. André julgou ser sim aquele o verdadeiro rei. de Vide narra esse encontro:

Chegou enfim o Rei verdadeiro chamado Dom José Primeiro à sobredita Banza, aonde se achava o Padre, e vinha com todo o seu acompanhamento Real, levado em sua rede aos ombros dos pretos, coberto com um grande Guarda sol, seguido de muita gente armada, caixas de guerra, e vários instrumentos musicais da terra, a Rainha, Infantes e mais pessoas Reais; e logo depois de pouco tempo, que mandou chamar ao Padre. Este o achou em sua casa de palha, como todas as do Reino, mas com vários labirintos até se chegar a ele Rei, que o recebeu com agrado, mas com todo o ar de magestade, pouco ou nada diferente dos Reis da Europa, e conheceu o Padre ser este o verdadeiro Rei do Congo aclamado de todo o Povo, principalmente dos grandes, que todos aí corriam a beijar-lhe a mão. ${ }^{114}$

Mesmo aceitando o fato do partido de José I ser o legítimo a ocupar o poder, os missionários evitaram assumir uma postura parcial, ao menos no plano de seu discurso nas fontes, buscando apaziguar os conflitos e fizeram de seu objetivo central missionar nas áreas rivais dos quinlaza. Um exemplo de atitude conciliadora por parte dos religiosos ocorreu durante a conquista de S. Salvador pelo grupo de Mucondo e a guerra com os partidários de Pedro V que se recusava a sair da capital. Segundo o relato, "mais de trinta mil homens armados de pólvora e bala" ${ }^{115}$ entraram em S. Salvador e venceram a guerra em menos de quatro horas. Depois disso, empilharam corpos dos

\footnotetext{
${ }^{113}$ Frei Rafael Castello de vide. Viagem e missão no Congo, p. 81-84.

${ }^{114}$ Frei Rafael Castello de vide. Viagem e missão no Congo, p. 89, 90.

${ }^{115}$ Frei Rafael Castello de vide. Viagem e missão no Congo, p. 120-122.
} 
inimigos na praça central e se recusaram a enterrá-los à maneira cristã. de Vide relata que pela "superstição" do Congo, ao sepultarem os corpos dos perdedores, morreriam também os vencedores numa guerra futura. Mas os padres insistiram em realizar o funeral, afirmando ser aqueles "corpos de cristãos, e que aqueles restos tinham sido templo do espírito santo" 116 e o fizeram no cemitério da ruina de uma antiga igreja.

$\mathrm{O}$ argumento da cristandade aparece constantemente no texto do missionário e foi utilizado para que congoleses de partidos opostos se identificassem como membros de um mesmo grupo, irmanados pela religião. A difusão geral da ideia do Congo como um reino cristão, que encontrava respaldo na própria identidade política congolesa era utilizada pelos padres para advogar por uma fraternidade católica que compartilhavam diferentes nobres congoleses, mesmo politicamente opostos. ${ }^{117}$

Logo após se estabelecerem em S. Salvador e reerguerem algumas das antigas igrejas que se encontravam em ruínas, os padres Rafael e André partiram para missão pelos interiores. Ambos se revezavam nesse trabalho, sempre permanecendo um deles na capital enquanto outro viajava pelos interiores, como exigia o rei. Nos primeiros anos após a posse de D. José I as missões se concentraram em territórios ocupados por inimigos de seu partido: Ensuco, Pango, Sumpi, Mpinda, Hiva, Quinzungue, Metombe e Quibango. ${ }^{118}$ No relato de de Vide há um embate constante com o rei e sua elite, que tentavam impedir que os padres adentrassem terras inimigas. Fica evidente que a presença exclusiva dos religiosos na capital e nos territórios aliados era interessante ao rei como ferramenta para impor-se sobre os inimigos. Também como ferramenta essencial para as práticas políticas cotidianas. Mas os padres tentavam resistir às vontades exclusivistas do Mani Congo, com a justificativa da necessidade de ampliar a cristandade para terras inimigas.

Um fato interessante ocorreu quando um poderoso chefe da província de Ensuco, do partido oposto ao Mani Congo, escreveu a Frei Rafael, requisitando a celebração do enterro de sua mãe na própria capital S. Salvador. Nesse caso a orientação

\footnotetext{
${ }^{116}$ Frei Rafael Castello de vide. Viagem e missão no Congo, p. 125.

117 Esse viés argumentativo dos missionários é importante para realizarmos a critica das fontes e buscarmos a intencionalidades ocultas. Interessa-nos nesta diss ertação, sobretudo, os usos do catolicismo pelos congoleses e seus interesses, que debateremos nos capítulos posteriores.

${ }^{118}$ Frei Rafael Castello de vide. Viagem e missão no Congo,p. 141.
} 
do padre foi de pedir ao Infante que viesse à capital e se submetesse ao Mani Congo primeiro, trazendo presentes ao soberano:

(...) porque fiquei satisfazendo a ele [chefe de Ensuco], e ao Rei, porque, ainda que este nos não proíbe irmos a todas as partes fazer missão, sempre deseja primeiro que os Infantes the venham obedecer, e então o Padre lá ir para ficar mais seguro no Reino e haver paz, ao que nós, quanto podemos, anuímos, segundo a recomendação que temos do Senhor Bispo, e havendo nisto alguma dúvida, nós a não temos, de acudir a todos. ${ }^{119}$

Neste caso, o missionário e a ritualística católica que dominava foi um elemento importante para que D. José I recebesse "obediência" de seus rivais, legitimando sua posição de soberano. O missionário destaca no relato sua agência nesta "conciliação", mas (como veremos no capítulo posterior) o missionário presente em S. Salvador acaba por cumprir (sem perceber ou sem admitir) a função de ferramenta do Mani Congo para aglutinar poder.

Outro exemplo semelhante ocorreu algum tempo depois, quando um "infante" de Mbamba saqueou a caravana vinda da colônia de Angola com os suprimentos e os escravos da igreja. O rei, muito contrariado com o fato, quis vingança e planejou enviar um exército para guerrear com os rebeldes. O franciscano novamente interveio: "Eu lhe roguei para que não o fizesse mal, e que nós vinhamos pela salvação deste Reino, e não para a destruição...". ${ }^{120}$ Pe. André se apressou para resgatar os escravos de forma pacífica. Mas neste caso a diplomacia dos religiosos falhou e o rei enviou seus "irmãos" das terras da rainha (vizinhas à Mbamba, separadas pelo rio Ambriz) castigarem o usurpador, recuperando os escravos, alguns mantimentos e destruindo as plantações dos rivais.

D. José morreu no ano de 1784 e o seu sucessor foi seu irmão, o já citado D. Afonso de Leão, marques de Mpemba, alto membro da elite, muitíssimo próximo aos padres. A posse do novo rei, que era mestre da igreja e tinha perfeito domínio do

\footnotetext{
${ }^{119}$ Frei Rafael Castello de vide. Viagem e missão no Congo, p. 215.

${ }^{120}$ Frei Rafael Castello de vide. Viagem e missão no Congo, p. 141.
} 
português , animou aos missionários e o bispo de Luanda, pois para eles abria-se uma nova esperança para a reaproximação entre Portugal e Congo via cristianismo. Mal sabiam que as questões que envolviam política, religião e comércio no Congo eram mais complexas do que pareciam.

\section{6: D. Afonso V e a ofensiva diplomática portuguesa}

$\mathrm{O}$ reinado de Afonso $\mathrm{V}$, apesar de muito curto, foi fartamente documentado e repleto de fatos decisivos para compreendermos a atuação portuguesa e a relação entre interesses comerciais e a missão católica. Como já dito, Afonso V, mesmo antes de se tornar rei já havia chamado atenção de Fr. Rafael pelo engajamento com a igreja católica, da qual Afonso era mestre catequista e pela "urbanidade de português" e o conhecimento da língua portuguesa.

O bispo de Angola e Congo soube através da terceira parte da relação de de Vide, enviada em Fevereiro de 1784, que D. Afonso V tinha sido coroado como novo rei do Congo. Assim que recebeu a notícia, Frei Alexandre da Sagrada Família, remeteu uma carta ao rei do Congo, comemorando a possibilidade de se comunicar diretamente em português com o letrado rei. Nesta carta, além de tratar de temas da religião, o prelado age como porta voz do projeto comercial português reclamando da pouca participação portuguesa na compra de escravos dos congoleses:

(...) os vassalos de V. Majestade felizes pela amigável aliança, que subsiste entre os dois impérios; a qual aliança pouco interessa a mesma Senhora [Rainha de Portugal] pelo pouco comércio que os Vassalos de V. Majestade hoje fazem com os Portugueses. ${ }^{121}$

D. Afonso $\mathrm{V}$ enviou também correspondência à diocese, provavelmente antes de receber a carta citada anteriormente, na qual o Mani Congo pede por mais missionários. Afonso e Leão, mesmo antes de se tornar rei, tinha sua legitimidade de chefe (na época

\footnotetext{
121 Arquivo Histórico Ultramarino, AHU, papéis de angola, cx 70 doc 28. Possuo cópia digitalizada. Além das transcrições disponibilizadas por Arlindo Correa em: www.arlindocorrea.com.
} 
Marques de Mpemba) muito atrelada aos elementos cristãos. ${ }^{122}$ Mas, ao contrário do Bispo de Angola, o rei apresentou interesse numa reaproximação inicial apenas no âmbito religioso, sem citar interesse em parcerias comerciais com Luanda, que como vimos não era comercialmente favorável aos nobres congoleses. Tampouco favoráveis à sua soberania, pois os portugueses foram os principais inimigos dos reis do Congo desde meados do século XVII.

Junto à primeira correspondência do bispo ao Mani Congo chegou ao missionário Fr. Rafael uma orientação para que fosse a Luanda, acompanhar dois novos missionários, que haviam sido delegados também para o Congo. Ele chegou à Luanda em 11 de Julho de 1785 acompanhado por um embaixador do rei do Congo, que portava uma nova carta enviada por Afonso $\mathrm{V}$ ao bispo e outra ao Governador Geral de Angola. ${ }^{123}$ Ambas as cartas, ao contrario daquela anteriormente citada, tratam de comércio de cativos, e apresentam a retomada dos negócios com portugueses como de interesse do rei do Congo. Ao prelado escreve:

Conheço e agradeço nisto muito quanto a minha Irmã Soberana Rainha de Portugal faz pelo bem do meu Reino, e Reis antigos tiveram boa amizade, quanto ao negócio, venham todos sem medo, eu quero que os Portugueses venham sempre aqui negociar com a minha gente e já vêm muitos. ${ }^{124}$

E ao Governador Geral: “(...) esta minha Real Carta é feita por minha mão em sinal de amor e boa amizade e quero que todos os portugueses venham aqui negociar como dantes, sem medo, porque eu os hei-de defender e não poderão padecer algum mal. "125

\footnotetext{
${ }^{122} \mathrm{~A}$ carta do rei foi escrita apenas nove dias após a data de assinatura da carta episcopal e as correspondências, em geral, demoravam mais do que isso para chegarem de S. Salvador à Luanda.

${ }^{123}$ Ultramarino, AHU, papéis de angola, cx 70, doc 8. Frei Rafael Castello de vide. Viagem e missão no Congo, p. 237-238, aqui o Frei descreve o envio das cartas e da embaixada do Congo para Luanda e depois uma de Luanda ao Congo. Correa, Arlindo. O missionário e o Negócio. 2007, p. 17. http://www.arlindo-correia.com/041207.html

${ }^{124}$ Arquivo Histórico Ultramarino, AHU, papéis de angola, cx 70, doc 28.

${ }^{125}$ Frei Rafael Castello de vide. Viagem e missão no Congo, p. 89, 90.
} 
Faz-se importante comparar a primeira carta do rei, escrita em Janeiro de 1785 e o conjunto das duas outras escritas três meses depois e levadas por de Vide e o embaixador à Luanda. Um questionamento importante seria a razão de essa primeira correspondência ignorar a questão comercial e as outras duas trata-la como central, convidando os portugueses para ir a São Salvador. Um dos possíveis motivos seria o fato de que quando o Mani Congo escreveu a primeira correspondência ele ainda estava carente de padres e quando escreveu a segunda já havia recebido a notícia que a diocese direcionara dois novos missionários para seu reino, o que dobraria de dois para quatro o número de padres europeus em sua corte. Dessa forma, a maior receptividade de D. Afonso $\mathrm{V}$ quanto à possibilidade de receber representantes comerciais europeus na corte congolesa poderia estar ligada à oferta dos novos padres. Luanda não oferecia muitos atrativos comerciais para fazer frente aos produtos de seus concorrentes europeus, mas detinha o controle sobre a presença e o envio de padres: "moedas de troca" de alto valor para os soberanos do Congo.

Se aceitarmos tal hipótese como motivação do repentino interesse do Mani Congo em comerciar com portugueses, devemos levantar questionamentos sobre a atuação dos padres Fr. Rafael e Pe. André junto à corte congolesa. Aqui o faremos sobretudo sob a perspectiva dos padres. No capítulo seguinte aprofundaremos a perspectiva congolesa, nosso interesse primordial

Fica evidente no quarto relatório de Frei Castelo de Vide, sua atuação como agente diplomático das autoridades lusas para barrar o comércio com os concorrentes europeus da Coroa portuguesa. Nesse relato, de Vide quer reforçar junto aos seus principais interlocutores: bispo e Capitão Geral de Angola, seu esforço em convencer as elites do Congo em não mais comerciarem com holandeses e ingleses; denominados de "hereges" por serem protestantes. Mas esse esforço foi quase sempre inútil:

(...) e nós mesmos vimos frustrados os nossos intentos, que eram ver se podíamos atalhar aquela venda dos Cristãos para os hereges, porque, visto eles se venderem uns aos outros, fossem ao menos os escravos para terras de Católicos, já que não podíamos de todo atalhar, e em secundário seria algum bem ao Estado, e se poderiam continuar estas Missões, e serem os Padres mais bem assistidos pela maior comunicação entre as duas potências, e franqueza dos caminhos, mas 
tudo tem sucedido pelo contrário, e a iníqua venda para os hereges persiste, e o negócio dos brancos acabou. ${ }^{126}$

É importante notar como o argumento religioso aparece como justificativa da promoção dos traficantes portugueses como mais adequados para parceiros dos comerciantes de escravos congoleses por serem também cristãos. Como podemos observar no excerto acima, os europeus protestantes são definidos como "hereges" e os "brancos" ou "católicos" são definição para os portugueses. Nessa curiosa argumentação do Padre, os congoleses estão muito mais próximos dos portugueses, por serem católicos, do que seus vizinhos protestantes da Europa. O catolicismo aparece aqui como elo que liga Portugal e o reino do Congo como reinos irmãos, e os diferencia dos hereges europeus e dos gentios africanos não católicos.

Como discutimos anteriormente, de Vide usa o argumento do cristianismo para afirmar existir uma proximidade entre os membros da elite do Congo e mercadores portugueses, e assim justificar essa parceria mais adequada no campo da fé. Ele vai ainda além, argumentando que os próprios escravos congoleses, por serem católicos, não deveriam ser vendidos para hereges e sim para mãos de traficantes cristãos e que os próprios escravizados temem por sua alma quando entregues às mãos heréticas dos protestantes:

Deus parece que permite pelos pecados do povo este mal que até aos mesmo Mexicongos é gravoso: estão vendo ir os seus filhos para os hereges; os mesmos que vão vendidos para eles choram, gritam, temem, queriam antes ir para os Católicos, e o mal não se remedeia, cada vez cresce mais; os Padres clamam, não são ouvidos, nunca the dissemos que os vendessem aos nossos ainda quando aqui estavam, para eles não cuidarem, que era amor da Nação, e não das suas almas, mas hoje se desenganam; que não há negócio dos Portugueses, e nós não cessamos de clamar, (....). ${ }^{127}$

\footnotetext{
${ }^{126}$ Frei Rafael Castello de vide. Viagem e missão no Congo, p. 254.

${ }^{127}$ Frei Rafael Castello de vide. Viagem e missão no Congo, p. 158-159.
} 
Diante dessas evidências, não restam dúvidas da relação entre missão católica no Congo nas décadas finais do século XVIII e o projeto comercial português de retomar o monopólio, ou ao menos retomar parte significativa do tráfico de escravos na costa congolesa. Parece evidente também que a atuação missionária nesse projeto é determinante, e é ancorada num ideário da cristandade como campo que aproxima portugueses dos congoleses, definidos como irmãos, e torna hereges ou gentios todos não católicos, independente se sua origem era europeia ou africana.

Neste contexto, os missionários foram delegados das autoridades portuguesas para cumprirem funções temporais essenciais para engordar os cofres da Coroa portuguesa. O que justifica o grande empenho financeiro da Coroa nas missões, era (para além do projeto de catequese) um investimento do qual se esperava retorno em forma de parcerias no tráfico de escravizados. Essa pressão das autoridades de Luanda colocava os missionários em situação bastante delicada, como nos relata Frei Rafael:

A primeira e segunda relação que se tem feito em comum, de nós todos, os Missionários do Congo, já as tem enviado para a nossa Soberana, o Senhor Bispo de Angola, por ele no-las mandar fazer de tudo. Agora espero as suas ordens para escrever esta terceira, de que eu me mandei escusar, de que não sei o que aquele Senhor ordenará. Eu, só como filho, quisera contar à Santa Província, minha mãe que como tal desculpará os meus defeitos, o que passo, e faço fora dela. ${ }^{128}$

\section{7: O fracasso do projeto comercial português}

O resultado da ida de Frei Rafael e da embaixada congolesa que portava cartas do rei Afonso $\mathrm{V}$, que convidavam os portugueses a enviarem seus representantes comerciais, parecia antever uma vitória angolana. Junto à comitiva que voltou para $\mathrm{S}$. Salvador foram dois novos missionários Frei José dos Sacramentos e Frei José de Torres, missionários agostinianos portugueses. Junto aos religiosos, foi delegado pelo

\footnotetext{
${ }^{128}$ Frei Rafael Castello de vide. Viagem e missão no Congo, p. 158.
} 
Capitão Geral um representante militar de Luanda, tenente de infantaria, como embaixador nos negócios portugueses para negociar com o Mani Congo e outras autoridades congolesas a retomada da parceria na compra de escravos. Além desses, retornavam para o Congo vários carregadores escravos da igreja, o embaixador congolês e alguns ambundos.

Ocorreu que no caminho todos sofreram muito com doenças graves, tendo inclusive um dos novos padres, Fr. José do Sacramento, falecido no caminho. Vários membros da caravana passaram por terríveis enfermidades que os retiveram por muitos dias em Mbanza Mbumbi, nas margens do rio Loge, o que tornou impossível o prosseguimento da viagem. de Vide enviou uma carta ao capitão da igreja da província de Mbamba pedindo socorro, então foi enviada uma comitiva para resgatá-los daquelas terras repletas de pestes. Depois de uma árdua e longa jornada, chegaram à capital do Congo em setembro de 1785 e como de costume foram recebidos por muitas festividades pela elite real, o que deu aos "brancos"129 verdadeiras esperanças no sucesso da empreitada. ${ }^{130}$

Ocorreram diversos encontros do embaixador lusitano com D. Afonso V para tentar estabelecer acordos sobre o crescimento da participação portuguesa no tráfico de escravos. Mas os representantes portugueses exigiam também o fim dos negócios com holandeses, franceses e ingleses, e a retomada do antigo monopólio dos primeiros anos de tráfico. Afonso $\mathrm{V}$ obviamente não cedeu às pressões e ofereceu aos portugueses uma pequena fatia do comércio, sem a promessa de reduzir o comércio já estabelecido com outros traficantes europeus. O impasse parecia sem solução e Afonso manteve-se firme em sua posição, o que obrigou o embaixador a se retirar de S. Salvador sem sucesso.

Alguns comerciantes luso-angolanos continuaram na capital, apostando em parcerias pontuais com traficantes ou membros da elite. Mas parcelas das elites congolesas começaram a se irritar com a tentativa de boicote do comércio com outras nações europeias e o nível de tensão crescia. O insucesso da missão portuguesa foi tamanho que os religiosos foram obrigados a escoltar parte dos luandenses e ambundos da embaixada portuguesa para fora do Congo, pois em muitos locais pelo caminho esses

\footnotetext{
${ }^{129}$ No texto de Castelo de vide o termo "brancos" é utilizado para mercadores portugueses ou angolanos (e possivelmente "brasileiros") de origem portuguesa, sempre católicos. Os europeus não católicos são chamados de hereges. Cita também ambundos, que vão em nome das autoridades angolanas, nesse caso é possível que sejam mestiços de grupos ambundos com portugueses.
}

${ }^{130}$ Frei Rafael Castello de vide. Viagem e missão no Congo, p. 239-244. 
eram ameaçados. O bispo Alexandre da Sagrada Família tentou intervir e advogar contra o tráfico para "hereges", escrevendo cartas diretamente aos chefes locais que controlavam a captura e venda de escravos na costa e ao próprio Mani Congo. ${ }^{131}$

A morte de D. Afonso V em 1787 desestabilizou ainda mais a relação entre congoleses e os agentes do império português em Luanda. Aliados do rei culparam os estrangeiros pelo repentino falecimento do Mani Congo, como descreveu Frei Rafael: "Por que essa gente sempre atribui as mortes, principalmente dos grandes, aos feiticeiros, que os matam e em cada morte destes há muitos distúrbios, e mortes de outros...". 132 Por isso, a presença de portugueses e ambundos no Congo ficou insustentável. Os padres foram, mais uma vez, os que garantiram a sobrevivência dos estrangeiros, protegendo-os contra hostilidades. O que demonstra que os padres ocupavam um lugar próprio no sistema social congolês, eles não eram considerados "brancos", tampouco estrangeiros pelas elites, mesmo em tempos de instabilidade.

Nessa situação política muito turbulenta foi coroado como sucessor de D. Afonso V D. Antônio II $^{133}$, um rei muito velho, que segundo Frei Rafael não exercia poder de fato, pois todas as suas decisões eram tomadas pelo conselho real ${ }^{134}$, por importantes membros da elite política central do Congo: de Mani Vunda, Mani Ololo e Manio Oembo. Diante dessa situação, os padres e o bispo tinham ainda menos influência sobre as decisões do Mani Congo e o tráfico realizado entre o interior e a costa, passando por S. Salvador e chegando aos portos do Norte, se intensificou ainda mais na capital do Congo. ${ }^{135}$

Os já citados vilis ou mobires eram os principais agentes na rota de escravos que passava por S. Salvador e se destinava aos portos ao norte de Soyo, na região de Cabinda. Como vimos, eram um grupo de comerciantes especializados estrangeiros originários principalmente de Loango e se faziam presentes na capital desde a restauração em 1709. Segundo Frei Rafael havia na capital, logo após a morte de

\footnotetext{
${ }^{131}$ Frei Rafael Castello de vide. Viagem e missão no Congo, p. 252-258.

${ }^{132}$ Frei Rafael Castello de vide. Viagem e missão no Congo, p. 260.

${ }^{133}$ Frei Rafael não nos informa o nome do rei, sabemos através de correspondências entre este e o governador de Angola: AHNA A-17-5 Oficios para Angola, fol. 67v. Barão de Mossamades para Antônio II, Agosto de 1787.

134 Infelizmente não temos notícia do nome em kikongo do que é chamado de "conselho real" pelas fontes.

${ }^{135}$ Frei Rafael Castello de vide. Viagem e missão no Congo, p. 291-292.
} 
Afonso V, mais de quarenta mobires em atividade, vendendo "muitos milhares" de escravos todo ano. ${ }^{136}$ Para a retórica dos missionários a ação dos vilis era ainda mais reprovável, uma vez que em sua maioria, ao contrário dos congoleses, não se viam como cristãos. Por isso eram vistos como "gentios" que vendiam congoleses cristãos aos heréticos protestantes ingleses e holandeses. ${ }^{137}$

Frente a esta situação, a Igreja, representada principalmente pelo pontífice Alexandre da Sagrada Família, à frente do bispado do Congo e Angola assumiu medidas drásticas (em sua concepção) para barrar esse comércio; como nos relata de Vide:

(...)não deixando de fazer conhecer ao povo os mistérios da nossa Redenção, da Lei de Deus, e da Santa Igreja, apertando-o muito pelo ponto mencionado de lançar fora o iníquo negócio de se venderem os escravos cristãos para o gentio, para este os vender nas praias aos hereges, até fazer um Edital por ordem do Senhor Bispo, pregado nas portas da Igreja, com declaração de excomungados todos os que concorriam para esta iníqua venda; e apertando mais aos que tinham o negócio em seus quilombos. ${ }^{138}$

Mas o medo da excomunhão não parecia afligir os comerciantes (que em geral não se tinham como católicos), tampouco aos congoleses que corroboravam e lucravam com o comércio. Por isso, sem alternativa, Frei Rafael, segundo os seus relatos, ameaçou abandonar a corte e seu posto de vigário geral do Congo para voltar à Luanda e ameaçou fazê-lo antes da coroação do novo rei, evento que dependia de sua presença.

Os membros do conselho real se reuniram para debater a questão e decidiram pela permanência do missionário, que segundo suas palavras: "rogaram muito" para que ficasse, pois o reino não podia ficar sem seu vigário geral. Frei de Vide, vendo a oportunidade de negociação, fez três exigências para que desistisse de partir. A primeira foi o fim das "mancebias" pelos chefes, cada um deles deveria permanecer apenas com

\footnotetext{
${ }^{136}$ Frei Rafael Castello de vide. Viagem e missão no Congo, p. 186-188.

137 "Gentio" é a constante denominação de de vide para africanos não católicos, usada geralmente para estrangeiros ao reino do Congo, que se diferem dos "hereges", europeus não católicos.

${ }^{138}$ Frei Rafael Castello de vide. Viagem e missão no Congo, p. 285-286.
} 
a esposa com quem eram casados na igreja. A segunda foi que pressionassem todo povo para que se confessasse anualmente e fosse à missa aos domingos. A terceira e mais importante era que cessassem os negócios com "hereges" e expulsassem os mobires "gentios" da capital. O conselho, segundo o que nos diz o padre, afirmou que concordava em cumprir as condições e o franciscano concordou em coroar o novo Mani Congo Antônio II. ${ }^{139}$

Apesar de Frei Rafael destacar seu poder em pressionar os membros do conselho e o rei, é questionável que ele gozasse desse poder e da autonomia de abandonar o Congo por decisão própria. Veremos no próximo capítulo que a relação de dependência entre missionários e reis do Congo no século XVIII é de natureza mais complexa e particular do que as fontes a princípio nos apresentam. Uma leitura mais aprofundada da documentação nos apresenta uma relação menos horizontal e autônoma por parte dos padres europeus.

Como era de se esperar, a elite reinante do Congo não tomou providência alguma sobre a presença de mobires e a venda de "cristãos para hereges" e é improvável que tenha seguido as outras exigências. Enfurecido com tamanho desdém, Frei Rafael decidiu tomar uma medida drástica para um missionário (europeu) cristão: a excomunhão. Munido de sua cruz saiu no dia 22 de julho rumo à região aonde os vendedores de escravos mantinham seus quilombos para excluí-los definitivamente da comunidade cristã.

O significado europeu da excomunhão: exclusão da comunidade cristã, por conseguinte a privação da alma da possibilidade da salvação, talvez não fizesse muito sentido para os congoleses praticantes de ritos católicos, e muito menos para comerciantes vilis não congoleses. Mas o significado local deste ritual era associado a uma poderosa maldição. O ritual da excomunhão tinha o nome de loka em kikongo e deriva da mesma raiz semântica das palavra ndoki e kindoki (plural); que dizem respeito a indivíduos que manipulam forças do outro mundo para causar malefícios individuais ou benefício próprio e de seus clientes, gerando desequilibrio. ${ }^{140}$ Os padres europeus eram chamados de nganga, que diferentemente dos kindoki agem magicamente em benefício de um indivíduo e na manutenção do equilibrio social; mas no momento de

\footnotetext{
${ }^{139}$ Frei Rafael Castello de vide. Viagem e missão no Congo, p. 188, 189.

${ }^{140}$ Thornton, John. The Kongolese Saint Anthony. Dona Beatriz. Kimpa Vita and the Anthonian moviment, p.72-73.
} 
radicalizações rituais como a excomunhão, os padres parecem ser vistos como perigosos kindoki.

Os tais "quilombos" pareciam ser locais nos entornos da capital onde os vilis ou mesmo congoleses mantinham escravizados capturados em guerras ou vindos de caravanas e feiras no interior. Dali os vilis os levariam para os portos ao norte (e em menor quantidade ao porto de Mpinda em Soyo). $\mathrm{O}$ primeiro alvo da furiosa excomunhão de Frei Rafael foi o proprietário de um dos principais quilombos, este localizado numa região central de S. Salvador:

Pelo que me determinei deixar o Rei, e ir ao Quilombo de um pequeno Infante, chamado por apelido Bua Lau, que na nossa língua é cachorro doido, o mais pertinaz e caixa universal dos Mobires e como Infante menos obediente ao Rei, e aos Padres, já avisado e sabendo que com ele falava o Edital da Igreja, e era o principal objecto, a que se encaminhava o meu zelo (...). ${ }^{141}$

Bua Lau parecia ser um congolês, pois é chamado de infante pouco obediente ao rei e por ser "o mais pertinaz caixa universal dos mobiri" e não ele próprio um mobire. Parece ser um grande negociante de escravos, que tratava com mobires que vinham das rotas do interior e revendia a outros vilis que fariam o caminho aos portos no litoral. Voltemos ao interessante episódio da excomunhão:

Entrei eu primeiro no seu Quilombo com o meu Santo Cristo, e tanto que o homem nos viu, como o demónio, assim se enfureceu saltando de roda de mim, escorvando a sua espingarda, apontando não sei, gritando como louco, enchendo-nos de injúrias, ele com a sua gente, levantado contra os Mestres, que levavam o Padre para o matar, que nós éramos feiticeiros, que tínhamos matado os Reis, e olhando para mim com muita raiva, me chamou seu feiticeiro [certamente usou o

\footnotetext{
${ }^{141}$ Frei Rafael Castello de vide. Viagem e missão no Congo, p. 292.
} 
termo ndoki], que no Congo é uma grande injúria, pelo que se perdem famílias inteiras. ${ }^{142}$

Após a batalha ritual contra Bua Lau, o missionário seguiu por outros quilombos e junto aos seus mestres de igreja excomungou diversos comerciantes, recebendo algumas ameaças, acusações e injúrias, mas sem nenhuma ameaça concreta à sua vida. Retornou a corte irredutível, convencido a pressionar o rei ao máximo.

Percebendo que apenas excomunhão dos comerciantes pouco adiantaria, de Vide e seus colegas resolveram fechar a igreja, cobrir todas as imagens de santos, interrompendo todo e qualquer sacramento para os moradores de São Salvador. A tensão era tamanha que negou ao filho do rei o sacramento da extrema unção. O Mani Congo, julgando a atitude do padre insolente, the enviou uma carta reclamando e acusando-o de não saber realizar os sacramentos da maneira devida, citou inclusive uma ocasião na qual Frei Rafael havia atendido sua confissão de maneira errônea. ${ }^{143}$

Segundo os relatos do missionário, a atitude de afronta do rei em relação à igreja fez com que nobres de outras províncias importantes fizessem críticas a S. Salvador e enviassem cartas em seu apoio. Um dos exemplos citados foi a província de Soyo, que mesmo independente do reino tinha grande influência e poder econômico. ${ }^{144} \mathrm{O}$ marques de Quibango, amigo e afilhado de Fr. Rafael, também repudiou a atitude do novo rei e convidou os padres a mudarem sua sede para sua província e ocuparem o antigo hospício capuchinho construído no século XVII.

A vinculação dos comerciantes de escravos que agiam em S. Salvador, vilis ou congoleses, com os detentores do poder central no Congo são bastante nebulosas. Mas é evidente, pela atitude narrada por frei Rafael, uma convergência de interesses entre a elite política e a elite econômica do tráfico na capital. Frei Rafael descreve em seu relatório que a postura tolerante do Mani Congo e sua elite era para além da tolerância deste trato, era de interesses econômicos, uma vez que recolhiam tributos sobre a atividade, chamado baculamentos.

\footnotetext{
${ }^{142}$ Frei Rafael Castello de vide. Viagem e missão no Congo, p. 290-292.

${ }^{143}$ Frei Rafael Castello de vide. Viagem e missão no Congo, p. 285.

${ }^{144}$ Frei Rafael Castello de vide. Viagem e missão no Congo, p. 295.
} 
Pelo que, tendo notícia que os gentios negociantes dos escravos Cristãos, para os tornarem a vender aos hereges ainda estavam na Corte, e que o Rei, e mais conselheiros se descuidavam, vêem ir os seus parentes, muitos inocentes, etc.,(...) e ficam muito sossegados, e aprovam o negócio pela ambição de receberem os seus baculamentos ou direitos, os que lhes pertencem. ${ }^{145}$

O impasse entre os missionários e as elites políticas persistiu até que o rei foi obrigado a nomear três importantes nobres do partido oposto ao seu com o título de Cavaleiro da Ordem de Cristo. A oferta deste título era uma das principais fontes de legitimidade e de renda do rei do Congo no século XVIII e sua estabilidade e reconhecimento frente a inimigos e aliados dependia do mesmo. Esse ritual exigia a participação do padre e do rei, que deveriam vestir simultaneamente o nobre com o hábito de Cristo, vestimenta que tinha bordada a imagem de uma cruz. ${ }^{146}$

Tendo sua legitimidade ameaçada pela recusa do padre em nomear os cavaleiros, o Mani Congo foi obrigado a retirar (ou apenas fingir retirar) o apoio aos mobiri e novamente prometer que expulsaria os comerciantes de S. Salvador. O soberano fez com que o comerciante Bau Lau fosse se retratar publicamente aos padres durante a missa e pagar mucanos (indenização) à Igreja. Apesar de desconfiados que os comerciantes tivessem desaparecido apenas provisoriamente de Vide e Pe. Godinho acabaram por nomear os tais Cavaleiros, como queria o rei. ${ }^{147}$

Frei Rafael interrompeu sua narrativa nesses fatos, pois precisou retornar à Luanda para tratar de uma grave doença em Junho de 1788 e depois disso voltou definitivamente para Lisboa. Pe. André Godinho continuou em S. Salvador ainda por alguns anos.

Há para esse contexto, um conjunto de correspondências escritas pelo então recém-empossado Governador Geral de Angola José de Almeida e Vasconcellos, Barão de Mossâmedes em 1787. Essas cartas foram enviadas a cada um dos três missionários que atuavam no Congo e uma delas para o novo rei do Congo. Em sua carta a D.

\footnotetext{
${ }^{145}$ Frei Rafael Castello de vide. Viagem e missão no Congo, p. 288, 289.

146 A concessão deste título será tema central no capítulo seguinte. Broadhead, Suzan. Beyond Decline (...) , p.7.

${ }^{147}$ Frei Rafael Castello de vide. Viagem e missão no Congo, p. 295-299.
} 
Antônio II é perceptível o sinal do descontentamento com a sua posição de fechar os olhos para os interesses portugueses:

Recebi a carta de vossa majestade de 29 do mês de Junho com a notícia de sua aclamação, após falecimento de Dom Afonso. Eu tomaria sua parte muito particular (palavra ilegível) nesse ingresso se os reis do congo correspondessem como deviam a boa amizade e proteção de sua Mag. Fidelíssima Rainha de Portugal, minha senhora havendo-se agrado a mandar-lhe S. esses que ensinassem no Congo o caminho da salvação, administrando os santos sais aos que quisessem abjurar os erros do gentilismo. Nem deste incomparável benefício, nem de franquear-se o negócio da capital de Angola, tem os antecessores de vossa majestade D. José e Don Afonso, dado a menor prova de gratidão(...)nem ao menos tem manifestado posição sobre a embaixada, o seu agradecimento ao general e vice rey da rainha de Portugal. ${ }^{148}$

O mesmo rancor aparece nas cartas enviadas aos missionários Frei Castelo de Vide, José de Torres e André do Couto Godinho, demonstrando que as autoridades de Luanda já não esperavam por soluções diplomáticas para barrar o comércio de escravos com holandeses, franceses e ingleses. O que talvez explique a rispidez do governador com o D. Antônio II e o fato de falar em enviar seus exércitos ao Congo. Ao pedir forças e paciência aos missionários, fica claro que para Mossâmedes esse projeto já estava perdido, parecendo também associar a falência do projeto comercial com a falência da missão católica. Para Frei Rafael escreve:

Mas a mão de Deus não the abreviada naquela que pode tudo, mas eu já do Congo não espero nada, suposta a inércia e impotência de seus reys, cuja eleição se (palavra ilegível) pelos seus vassalos se assim se

\footnotetext{
148 AHNA A-17-5 Oficios para Angola, fol. 67v. Barão de Mossamades para Antônio II, Agosto de 1787. Possuo uma cópia digitalizada desta e das três cartas da mesma data para cada um dos missionários trabalhando no Congo na época. Agradeço mais uma vez ao Prof. Thornton por ter disponibilizado também essas cópias.
} 
prometem o amar os que elegeram rei um pateta, que senão ganho aos seus súditos e os deixe viver na mesma enganação(...)". ${ }^{149}$

Escrevendo para Pe. André, Mossamedes mostra-se ainda mais pessimista e crítico em relação à atitude das elites do Congo:

Estando aflicto por não saber de SM e dos seus bons companheiros [os missionários] (...) sabendo a constância com que todos três trabalhão no bem do Congo, da rebeldia em que permanece esses gentios infatuados com os nomes pomposos de títulos de Infantes de titulo de Fidalgos sem saber em que consiste essa gradação nem procurarem imitar as nações civilizadas e muito menos fazem-se cristãos. ${ }^{150}$

Observando a falência do projeto português e os fatos anteriormente relatados podemos levantar algumas questões sobre a relação entre Congo e Portugal e o lugar do cristianismo nessa relação durante a segunda metade do século XVIII. Diversos elementos católicos foram incorporados ao sistema de poder no Congo, tema que será abordado mais profundamente no capítulo seguinte. Tais elementos se constituíram como um dos pilares de legitimidade do Mani Congo e de outros membros das elites locais durante o período. Os membros da elite congolesa se denominavam católicos, entendendo o catolicismo como o conjunto de elementos simbólicos de origem cristã, incorporados ao seu sistema religioso por uma tradição de três séculos de contatos com o cristianismo. E por isso, necessitavam da presença de clérigos europeus para manutenção dessa legitimidade.

Por sua vez, para os portugueses, o fato das mais poderosas elites congolesas necessitarem de elementos católicos e padres europeus para a ritualização cotidiana do poder foi visto como uma oportunidade para realizar alianças ancoradas no argumento religioso. Assim, excluiriam seus concorrentes de origem não católica (romana):

\footnotetext{
${ }^{149}$ AHNA A-17-5 Oficios para Angola, fol. 67v. Barão de Mossamades para Fr. Rafael Castelo de vide, Agosto de 1787.

150 AHNA A-17-5 Oficios para Angola, fol. 67v. Barão de Mossamades para Pe. André do Coutto Godinho, Agosto de 1787.
} 
principalmente ingleses (anglicanos) e holandeses (protestantes) e se tornariam os parceiros naturais, retomando o controle do comércio na costa do reino.

Os congoleses, diante dessa pressão feita pelos missionários, se viam em um impasse: não poderiam abrir mão dos negócios com holandeses, franceses e ingleses, pois estes ofereciam às elites bens de luxo e riqueza, o que os permitiam alargar suas alianças e ampliar seu poder sobre as pessoas e respeito frente aos inimigos. Ao mesmo tempo, elementos católicos também eram fontes essenciais de poder e a proximidade dos missionários os legitimava em suas elevadas posições sociais e os vinculava ao passado glorioso dos grandes reis católicos e da centralização do poder. E a manutenção desses elementos de legitimidade dependia do patrocínio do bispado e do governo sediados em Luanda.

Os missionários também se encontravam no meio de um "fogo cruzado" entre as autoridades portuguesas e as autoridades congolesas. Eram pressionados pela Coroa portuguesa a aderirem à sua causa comercial, vinculando-a ao catolicismo e utilizando seu prestígio frente às elites do Congo para travar negociações. Mas uma vez incorporados ao sistema religioso congolês, os padres não possuíam tamanha autonomia e poder de negociação.

Fica evidente que o insucesso da negociação com o Mani Congo e as elites congolesas ocorreu pelo fato dos missionários e membros da Igreja europeia terem falhado ao enxergar a relação dos congoleses com elementos de origem católica como algo próprio, que foi construído historicamente pela tradição simbólica congolesa. Não perceberam que estavam jogando um "jogo" simbólico com regras pré-determinadas e diferentes das suas. Por isso, sua derrota foi inevitável.

Diante da proposta do governador de Angola ao rei do Congo, percebemos que a estratégia inicial da aproximação dos antigos "irmãos" Congo e Portugal pela via do catolicismo não funcionara e frente ao fracasso do projeto há uma tentativa de justificar uma nova aliança, não mais ancorada em religião, mas em exército. O governador de Angola escreve ao rei do Congo:

Se v. Magestade não tem forças para punir aos maus, rogue a rainha minha Senhora que com a sua ordem mandarei ao Congo Cavalaria, 
Infantaria e artilharia que reduza os rebeldes a devida correção obrigando a todos a conhecer quem os governa. ${ }^{151}$

Ao sugerir que o rei Antônio II encontrava-se incapaz de governar e de "reduzir" os rebeldes, o administrador português busca uma oportunidade e uma justificativa para penetrar militarmente no Congo.

Ora, se Luanda dispõe de "infantaria, cavalaria e artilharia" e ambicionava há um século retomar a participação nos portos e as rotas congolesas, por que não lançou ataques ao Congo, no momento de fragilidade após a morte de D. Afonso V, ainda mais após a expulsão da embaixada luandense do reino? Se Luanda de fato dispunha de tamanho poderio militar, por que Portugal não conseguiu se estabelecer em Ambriz (na região independente de Mossul, na foz do rio Loge) como almejou durante todo o século XVIII ${ }^{152}$ ?

O fato da licença do Mani Congo ser necessária para uma entrada no território pode ter relação com uma fragilidade militar portuguesa frente à capacidade de defesa militar congolesa. Porém acreditamos ser a autorização justificada, sobretudo pelo poder diplomático no campo "internacional" das elites congolesas, sobretudo do rei. Pelo poder que as elites congolesas ainda gozavam no plano da política externa, devido à lucrativa parceria com as coroas (e companhias de comércio) europeias: Inglaterra, França e holandeses e a enorme influência destas sobre a corte portuguesa. A proteção da região do Congo pelas potências parceiras no tráfico de escravos (assim como Mossul ao sul e Malemba, Kakongo e Loango ao norte) pareciam decisivas para manter distante a ameaça portuguesa e manter a soberania política africana.

O caso de Mossul é muito sintomático desta relação entre soberania africana e parceria com holandeses e ingleses. Os portugueses invadiram e ocuparam de fato este território apenas em 1855 e a partir deste período a portugueses começaram a expandir seus domínios em direção ao reino do Congo e desta vez ameaçarem de fato os

\footnotetext{
${ }^{151}$ AHNA A-17-5 Oficios para Angola, fol. 67v, p.59

152 Sobe Ambriz no século XIX: Wis senbach, Maria Cristina C. Entre caravanas de marfim, o comércio da urzela e o tráfico de escravos: Georg Tams, José Ribeiro dos Santos e os negócios da África centroocidental na década de 1840. Programa Nacional de Apoio à Pesquisa - FBN/MinC . 2008, p .29 -36. Disponível online em http://www.bn.br/portal/arquivos/pdf/MariaCristinaCortez.pdf e Wissenbach, Maria Cristina C. As Feitorias de Urzela e o Tráfico de escravos: Georg Tams, José Ribeiro dos Santos e os Negócios da África Centro-ocidental na década de 1840. Afro-Ásia, n 43. Salvador. Ceao, UFBA. 2011. p 43-90.
} 
territórios congoleses com ocupação militar. Após séculos de tensão e de defesa ferrenha por sua soberania diante dos portugueses, os congoleses viam-se fragilizados. ${ }^{153}$

Ora, este período de ocupação coincide com o movimento inglês de "proibição" do tráfico de escravos e do surgimento do (ainda mais lucrativo) trafico "ilegal". Desta forma, o poderio diplomático congolês frente aos seus parceiros europeu se esvaziou gradativamente, uma vez que o tráfico humano tornara-se contrabando e ilegal aos olhos da grande potência britânica.

Nosso recorte temporal não chega ao século XIX e não pretendemos nos aprofundar nesse processo, muito particular em relação à segunda metade do XVIII. De qualquer maneira, tais reflexões nos apontam para a importância que o Congo tinha junto às potências europeias, o que favorece a manutenção de sua soberania política durante o século XVIII.

Ora, se a diplomacia para o além-mar era de tamanha centralidade para a manutenção da soberania política africana sobre o território, o Mani Congo, sendo um representante (mesmo que simbólico) deste local passa também a assumir um papel central para um vasto território desde o rio Dande até o porto de Loango e ao leste até o rio Nkisi. É evidente que o rei do Congo não gozava de controle militar e tributário sobre esta extensa região, mas seu papel diplomático frente a autoridades europeias tornava-o um líder importante desta localidade culturalmente aparentada.

As cartas do Barão de Mossamades ao rei Antônio II demonstram que o consentimento deste soberano sobre a presença portuguesa era fato essencial, por mais imponente que fosse seu exército e por mais fragilizado que este Mani Congo se encontrasse internamente. Como exemplos anteriores nos mostraram, uma simples carta do rei do Congo à Coroa inglesa ou mesmo à Companhia das Índias Ocidentais poderia bloquear imediatamente, pela via da política europeia, uma ação militar lusa no reino do Congo. Mesmo possuindo (aparentemente) condições militares suficientes para invadir o território congolês, o governador de Angola via-se inevitavelmente impotente diante do poder do rei do Congo no âmbito da política externa.

\footnotetext{
153 Wissenbach, Maria Cristina C. Entre caravanas de marfim, o comércio da urzela (...) p .29-36. E: O tráfico de escravos: Georg Tams, p 43-90.
} 
Nos capítulos seguintes, focaremos a política interna congolesa buscando compreender o funcionamento do complexo sistema político pós-restauração e o papel dos elementos católicos como ferramentas essenciais de poder e identidade no reino do Congo. 


\section{Capítulo 3: Catolicismo e Poder Central}

Os principais pesquisadores que se debruçaram sobre reino do Congo não se aprofundaram no período posterior a crise política do final do século XVII, como indicamos na introdução deste trabalho. Apesar dessa lacuna mais geral, o início do século XVIII chamou atenção dos estudiosos por ser considerado o marco do fim de uma era de desorganização do poder centrado em S. Salvador, ou seja, a "restauração" do poderio do Mani Congo e das estruturas de poder central. ${ }^{154}$

A coroação de Nessamo a Mbandu ${ }^{155}$ como rei do Congo no ano de 1709, nomeado D. Pedro IV foi o evento decisivo do período. Os principais autores: Vansina, Broadhead e Thornton apresentam ideias convergentes desse evento como marco do fim da era de desorganização política. O reinado deste Mani Congo, segundo os autores, rompeu com o período de desorganização e rivalidades desde a guerra de Ambuíla. ${ }^{156}$

Vansina aborda superficialmente o reinado de Pedro IV, mas afirma que este promoveu uma reunificação puramente simbólica, sem conseguir restituir o poder direto de sujeição dos chefes de província. ${ }^{157}$ John Thornton, por sua vez, se debruçou sobre o movimento Antoniano, evento imediatamente anterior à reunificação, através dos arquivos da Propaganda Fide em Roma, nos quais coletou documentos de autoria de missionários capuchinhos que apontam para Nessamo a Mbandu como responsável por uma "refundação" do sistema político congolês sobre bases essencialmente simbólicas, se comparadas aos alicerces de poder dos governantes em períodos de centralização. ${ }^{158}$

\footnotetext{
${ }^{154}$ Vansina. The kingdoms of the Savana, p. 190

${ }^{155} \mathrm{O}$ catálogo dos reis do Congo é um documento manuscito, de autoria desconhecida, atribuido por Broadhead ao mani Congo José I ou a algum de seus secretários. Há uma cópia no Instituto Histórico e Geográfico Brasileiro, Lata 6, documento 2, "Catallogo dos Reis do Congo". Possuo uma cópia da publicação da lista de reis com seus respectivos nomes em kikongo, gentilmente cedida pelo Prof. Thornton e publicada por Necessidades, Francisco. Factos memoraveis da História de Angola, Boletim Official do Governo Geral da Provincia de Angola no. 642 . 16 de Janeiro de 1858.

${ }^{156}$ Suzan H. Beyond Decline, p. 630-648.

${ }^{157}$ Vansina, J. Kingdoms of the Savana., p. 189-197.

${ }^{158}$ Thornton, John. The Kongolese Saint Anthony. Dona Beatriz. Kimpa Vita and the Anthonian moviment, p.97-121; Broadhead compartilha da mesma opinião. Broadhead, Suzan H. Beyond Decline, p. 630-648.
} 


\section{1: Unificação e organização política pós-unificação.}

A historiografia leu o termo Império nas fontes missionárias da segunda metade do século XVIII. Os autores utilizaram poucos relatos disponíveis. O principal e mais conhecido deles foi o do missionário Cherubino de Savona, publicado por Carlo Toso. ${ }^{159}$

Vejamos como Savona define a organização imperial: "O Reino do Congo, por melhor dizer Império, por que tem vários diferentes reinos e muitíssimas províncias, principados, ducados, está na etiópia meridional e é quase todo católico." 160

O relatório de Frei Rafael de Vide, datado de duas décadas depois de Savona também oferece uma definição semelhante:

Há este Reino muito antigo, dilatado, e hum grande Imperio, ainda que hoje se ache dividido entre muitos grandes levantados, que se separarao do Rey, mas sempre se reconhecem seus vassallos, e sugeitos; em a maior parte delle se abraça a fe Catholica. ${ }^{161}$

Ambas as descrições tratam do território como uma unidade política percebendo, ao mesmo tempo, ambiguidades nessa unidade no que tange o controle efetivo do soberano congolês sobre o território. Por isso, mesmo usando os termos "reino" e "império" como definidores, os diferentes graus de independência das províncias em relação ao rei chamou a atenção dos autores das fontes.

Savona descreveu atentamente a organização política congolesa, sobretudo as divisões locais. Para ele, o Congo era formado por vários diferentes reinos, muitíssimas províncias principados e ducados. Concluiu que o império abrangia quatro diferentes reinos, divididos em vinte e duas províncias. Estas províncias não estavam necessariamente contidas dentro de algum dos reinos, pois existiam províncias

\footnotetext{
${ }^{159}$ Toso, Carlo. Relazioni inedite di P.Cherubino Cassinis da Savona, p. 207.

${ }^{160}$ Toso, Carlo. Relazioni inedite di P.Cherubino Cassinis da Savona, p. 207.

161 Frei Rafael Castello de vide. Viagem e missão no Congo, p. 267. Broadhead em Trade and politics, e Vansina não consultaram o relatório de Frei Rafael. Broadhead citará esse missionário em artigo posterior, sem aprofundar-se muito no relato: Beyond Decline. 1979.
} 
independentes que mesmo sendo consideradas como parte do Congo, poderiam ser politicamente desvinculadas de S. Salvador, não participando ativamente das eleições do Mani Congo e das disputas políticas pelo poder central.

A principal dessas províncias era Soyo, localidade de grande importância e centralização política interna. As elites de Soyo tornaram-se autônomas de S. Salvador em meados do século XVII. O Mani Soyo não necessitava do rei para tomada de decisões internas (como ir à guerra e eleger novos chefes) e tampouco pagava tributos ao soberano no século XVIII. Mesmo sendo formalmente independentes, as elites de Soyo continuavam influentes na corte congolesa e reconheciam uma identidade comum. $^{162}$

O caso de Soyo e outros apresentados por Savona demonstra a dificuldade que os missionários encontravam em compreender a divisão política congolesa dentro do padrão da Europa moderna. Evidencia-se a insuficiência dos termos "província", "reino" e "império" como transmissores da especificidade dessa organização política. Podemos inferir, pelos relatos de Savona, que aquilo que chama de "reinos" eram territórios que disputavam pelo poder em S. Salvador e seus soberanos faziam parte da ancestralidade de reis do Congo. O termo "província", por sua vez, aparece de forma mais genérica, como um território mais ou menos autônomo, que poderia ter diferentes graus de dependência do rei do Congo, ou mesmo ser completamente independente. Pelas fontes, fica dificil estabelecer exatamente a relação entre os "reinos" e "províncias" ou mesmo compreender se uma província específica integrava ou não um dos reinos citados.

Os reinos que compunham o Império do Congo no século XVIII eram quatro: $\mathrm{S}$. Salvador, Mucondo, Lemba Grande e Oando. Havia diversas particularidades e diferenças entre cada um dos reinos e províncias no que tange à extensão territorial, número populacional e também na relação com o catolicismo. Notamos que os elementos católico eram muito presentes no cotidiano e essenciais para legitimação política das elites em algumas localidades, ao mesmo tempo que quase inexistentes em outras. Aprofundaremos a discussão sobre as especificidades de cada reino e das

\footnotetext{
162 Vale lembrar a intervenção dos chefes de Soyo no impasse entre Frei Rafael de vide e o mani Congo Antônio II, no embate sobre o tráfico em S. Salvador comandado pelos Mobiri. Frei Rafael Castello de vide. Viagem e missão no Congo, p. 295.
} 
principais províncias no capítulo seguinte, no qual discorreremos sobre os diferentes tipos de relação dos poderes locais com o catolicismo.

O mais relevante neste ponto de nossa discussão centrada no poder do rei em S. Salvador é observar as províncias como "parcialidades" que rivalizaram o poder central no período pós-restauração, o que faremos em seguida.

\section{2: Quimpanzo e Quinlaza e o debate sobre as makanda}

A primeira afirmação política fundamental no relatório de Frei Cherubino da Savona foi: "Seu rei é eletivo das duas famílias reais, que se chamam Quinpanzo uma, e Quinlaza a outra, e alternadamente governam de maneira que morrendo o Rei de uma, se elege de outra. Assim, vivem em paz. ${ }^{163}$

Os grandes grupos que disputavam a poder que foram chamados por Savona de "famiglia", foram definidos como "parcialidades" ou "partidos" por Frei Raimundo e Frei Rafael. ${ }^{164}$ Os termos "partido" e "parcialidade" aparecem como sinônimos, em sua acepção política no dicionário português de Raphael Bluteau, de 1729: genericamente como grupos que polarizam uma disputa. ${ }^{165}$ Grande parte da historiografia utiliza "kanda" (plural: makanda), termo em kikongo que definia grupos matrilineares entre os bacongo no início do século XX, genericamente chamadas de linhagem ou clã. ${ }^{166}$

A etnologia, desde o início do século XX, chama atenção para a centralidade dessas estruturas para a organização das sociedades não europeias, conforme a necessidade de um olhar sociológico que pretendeu compreende-las por uma lógica interna, pela interação entre as partes da estrutura social, numa perspectiva sincrônica.

\footnotetext{
${ }^{163}$ Tradução livre: "Il suo Ré è elletivo da due Famiglie Reali, che si chiamano Quinpanzo una, de Quimulaza l'altra, e alternativamente governo, di manera che morendo il Ré di uma, si elege dell altra, e così vivono in pace”. Toso, Carlo. Relazioni inedite di P.Cherubino Cassinis da Savona, p.207.

164 Toso, Carlo. Relazioni inedite di P.Cherubino Cassinis da Savona, p.207. O termo "parcialidade" aparece inúmeras vezes no relatório de Frei Rafael. Exemplo: Frei Rafael Castello de vide. Viagem e missão no Congo, p. 82.

${ }^{165}$ Vocábulo "partido". Raphael Bluteau. Vocabulario Portuguez \& Latino. 1729. Online em: http://www.brasiliana.usp.br/

166 "Linha (temo genealógico): A ordem em que os mesmos parentes em diferentes graos descendem do mesmo progênitos ou do mesmo tronco da arvore genealógica”. Raphael Bluteau. Vocabulario Portuguez \& Latino. 1729. Online em: http://www.brasiliana.usp.br/
} 
Um olhar diacrônico de longa duração para essas estruturas (objetivo dos estudos históricos) torna evidente, entretanto, a sua intensa fluidez e reinvenção de acordo com as demandas históricas de cada período. Desta forma, o olhar histórico acaba por esbarrar em constantes contradições com a visão estrutural sociológica, como observamos na historiografia sobre o Congo. ${ }^{167}$ Para uma compreensão mais aprofundada dessas estruturas que rivalizaram o poder do reino do Congo no período desta pesquisa, é essencial que abordemos panoramicamente o debate sobre as makanda e suas transformações na historiografia.

O pioneiro nos estudos do reino do Congo, Jean Cuvelier, é uma figura essencial na discussão sobre o papel das makanda na organização social e política no Congo. Cuvelier viveu entre 1907 e 1962 numa região habitada por falantes de kikongo, no período sob dominação colonial belga. Para Thornton, este autor foi o "mais influente historiador a escrever sobre as origens do Congo (...) e um mestre dos registros documentais do século XVI ao XVIII." 168 Além do extenso trabalho com fontes escritas, Cuvelier sintetizou diversas tradições orais, assistido por pesquisadores de origem e falantes do idioma do antigo reino, publicou-as em kikongo e através dessas fontes elaborou sua interpretação sobre as origens do reino do Congo. ${ }^{169}$ Não nos importa aqui debater as origens do Congo, o que nos interessa é a natureza das fontes orais que Cuvelier utilizou e a importância do debate sobre as makanda para a segunda metade do século XVIII.

As fontes orais essenciais nas coletâneas de Cuvelier foram as chamadas mfumu za makanda. Cada uma delas contava uma micro história familiar do informante, vinculando-os aos mitos de origem do reino do Congo. Desta forma, elas funcionavam na época de sua coleta como narrativas identitárias, reivindicando legitimidade do grupo narrado nos relatos com o objetivo de vincular a história familiar às glórias dos primeiros reis do Congo. Apresentavam, portanto, uma visão de fixidez e permanências sobre esse complexo sistema de organização "familiar" congolês na longa duração. ${ }^{170} \mathrm{O}$

\footnotetext{
${ }^{167}$ Caso exemplar sobre o Congo é a visão estruturalista em: Balandier, G. Daily life in the Kingdom of Kongo. 1969.

${ }^{168}$ Tradução livre: "Has been the most influential historian to write of Kongo origins;(....) He was a master of the sixteenth- through eighteenth-century documentary record(....)." Thornton, John K. The origins and early History of the Kingdom of Kongo, p 90.

${ }^{169}$ Thornton, John K. The origins and early History of the Kingdom of Kongo, p. 91.

${ }^{170}$ Thornton, John K. The origins and early History of the Kingdom of Kongo, p. 91.
} 
caráter de fixidez destes clãs, na forma com que aparecem nos discursos de autolegitimação no século $\mathrm{XX}$, parece incompatível com a fluidez que apresentam nos séculos XVII e XVIII. O que as torna problemáticas quando utilizadas para análises de processos históricos. Mesmo assim, essa história clânica de Cuvelier influenciou de maneira marcante a historiografia sobre o Congo durante todo o século XX.

Na conceituação de kanda, o antropólogo MacGaffey segue a visão de Cuvelier, sedimentando na historiografia congolesa uma visão estrutural sobre as mesmas. A partir dessas influências passou-se a utilizar esse conceito de kanda para interpretação de tempos históricos remotos, uma vez que para MacGaffey eram estruturas essencialmente imutáveis: "The kanda were exogamous corporate groups. They were perpetual and had defined names, tradition and membership". ${ }^{171}$ Esta mesma definição foi utilizada posteriormente por Anne Hilton para o reino do Congo dos séculos XVI e XVII, seguida também, mas parcialmente apenas, por Suzan Broadhead quando trata dos séculos XVIII e XIX. ${ }^{172}$

John Thornton foi o primeiro autor a questionar a aplicabilidade do conceito de kanda do período contemporâneo em interpretações históricas do antigo reino do Congo. Para o historiador, essas narrativas de clãs respondem a uma demanda histórica posterior ao século XIX. Neste período, segundo o autor, ocorreu um rearranjo no sistema de rotas comerciais no território congolês, o que transformou as relações de poder econômico e gerou disputas por legitimidade de diferentes grupos sociais. Esta disputa tinha como critério legitimador a precedência ou tradição no controle dos caminhos de comércio, por isso, faria sentido que as makanda de meados do século XIX e do século XX tenham defendido a ideia de tradição e apresentado-se como estruturas imutáveis. 173

Os termos kanda, clã ou linhagem estão completamente ausentes das fontes disponíveis da segunda metade do século XVIII. Os elementos que nossas fontes nos dão sobre "parcialidades" ou "famílias" são infelizmente insuficientes para um olhar

\footnotetext{
${ }^{171}$ MacGaffey,Wyatt. Changing representantions in central African History Journal of African History, $\mathrm{n}$ 46. Cambridge University Press. 2005, p.190.

${ }^{172}$ Hilton, Anne. Kingdom of Kongo. 1985. Broadhead recebe mais tardiamente a influência das ideias de MacGaffey: em sua tese de doutorado, Trade and Politics on the Congo Coast. 1971, não debate com este autor. Porém em Beyond Decline. 1979. MacGaffey aparece como referência central para a autora.
}

${ }^{173}$ Thornton, John K. The origins and early History of the Kingdom of Kongo, p. 90-116. 
mais aprofundado para essas estruturas. Ao mesmo tempo, nos mostra a fluidez e reinvenção das mesmas, que se adaptavam de acordo com os diferentes contextos dos jogos de poder internos ao Congo. A fluidez evidente no sistema de organização social e político durante os séculos XVII e XVIII nos impede de pressupor que as makanda destes períodos sejam as mesmas das observadas por Cuvelier e MacGaffey no século XX. As críticas de Thornton nos parecem bastante convincentes e sua metodologia mais adequada para um trabalho histórico que visa acessar a especificidade da estrutura política do período da segunda metade do século XVIII. Porém não descartaremos completamente o conceito de kanda (Thornton também não o faz). Ele será aplicado aqui numa acepção mais genérica e essencialmente política de "partido". Sabemos, entretanto, que a ancestralidade é um elemento central de legitimidade política nas sociedades africanas, por isso a definição "famiglia" de Savona, apesar de genérica nos dá outra dimensão importante dessas estruturas fluidas.

O sistema de alternância de poder entre as makanda quimpanzo e quinlaza foi instaurado na primeira década do século XVIII, no contexto da restauração e reorganização do poder centralizado pelo reunificador Pedro IV Nessamo a Mbandu. ${ }^{174}$ A partir do sucessor de Pedro, Manuel Makasa: Manuel II Mpanzu a Nimi de Quimpanzo, a rotação de poder passou a operar, chegando até o período das disputas de poder entre partidários de Pedro V (Nebica a Vita) e José I em 1779, que se saindo vencedor instaurou algumas décadas de sucessões exclusivas de reis de Quinlaza. ${ }^{175}$

Para compreendermos a polarização entre essas parcialidades no período setecentista faz-se necessário observarmos o contexto anterior de guerra civil e desorganização política do século XVII, no qual essas makanda nasceram. Este é um período particularmente turbulento e a sucessão de fatos políticos torna o entendimento do período uma atividade um tanto desgastante, porém a mesma faz-se essencial para relativizarmos o contexto de maior estabilidade setecentista.

O período entre as décadas de 1630 até a restauração da capital congolesa em 1708 foi marcado por intensos conflitos entre as makanda e o surgimento e

\footnotetext{
174 Toso, Carlo. Relazioni inedite di P.Cherubino Cassinis da Savona, p.207. Lista de sucessão dos reis: Necessidades, Francisco. Factos memoraveis da História de Angola, Boletim Official do Governo Geral da Provincia de Angola no. 642 . 16 de Janeiro de 1858, p. 1-3.

${ }^{175}$ Necessidades, Francisco. Factos memoraveis da História de Angola, p. 3.
} 
desaparecimento de varias delas num período curto de tempo. Assim como houve períodos de maior fixidez na organização social, o período de "reorganização" política do Congo foi, ao contrário, marcado por intensas transformações. ${ }^{176}$

No contexto interno, um dos principais fatores que gerou instabilidades, causando a reconfiguração de diversas makanda foi a tensão entre S. Salvador e Soyo existente em meados do século XVII. A mbanza de Soyo era como uma "segunda corte" ${ }^{\text {"177, }}$ possuía tradição de importantes soberanos, com forte e estável situação política. Desde o século XV (ou antes) Soyo possuía grande autonomia sobre S. Salvador e parceria com seu soberano era peça fundamental para legitimidade do rei. Soyo foi o palco dos primeiros contatos com os portugueses no século XV e o Mani Soyo foi batizado antes mesmo do Mani Congo Nzinga a Kuwu, evidenciando sua ascendência frente ao rei. O processo de emancipação de Soyo, iniciado no século XVII foi um dos pivôs da crise e desorganização política do reino, que se efetivou definitivamente pela derrota do Congo na batalha de Ambuíla em 1665. ${ }^{178}$

No início do processo que de autonomização das províncias, que disparou a crise política, Álvaro III Nimi a Mpanzu, da província de Bamba, foi o quarto rei eleito da kanda chamada Kuílo e foi coroado em 1615. Após a morte de Álvaro abriu-se uma disputa pela sucessão do poder, pois seu filho que daria continuidade aos Kuílo de Mbamba era muito jovem, assumindo então um nobre aliado, porém nascido na província de Nsundi: D. Pedro Nkanga a Mvika, coroado como Pedro II, marcando a transição para reis dessa região. D. Pedro rompeu com o legado anterior e foi assim instituída uma nova kanda nomeada "Casa de Nsundi” ou Kinganga. ${ }^{179}$

O fato de Mani Congos fundarem novas makanda, como fez Nimi a Mpanzo, não foi inédito na história congolesa. Alguns soberanos que estabelecessem novos paradigmas políticos poderiam fundar makanda vinculadas a si. Discutiremos adiante neste capítulo o principal fundador de uma nova tradição política: D. Afonso I.

\footnotetext{
${ }^{176}$ Heywood, Linda e Thornton J. K. Central African Creoles and The Foundation of the Americas, 135143

${ }^{177}$ Toso, Carlo. Relazioni inedite di P.Cherubino Cassinis da Savona, p. 209.

${ }^{178}$ Heywood, Linda e Thornton J. K.. Central African Creoles and The Foundation of the Americas, 135143

${ }^{179}$ Heywood, Linda e Thornton J. Central African Creoles and The Foundation of the Americas, p. 138143
} 
O período de meados do século XVII foi também de particulares tensões entre o Congo e a colônia de Angola, com a posse de João Correa de Sousa como seu Capitão Geral e Governador, inaugurando uma política de hostilidades portuguesas nos entornos de Luanda, inclusive em direção ao sul do Reino do Congo. Ao contrário de governadores anteriores que tentavam se aproximar do Congo pela via diplomática, Correa de Sousa acreditava na efetividade da guerra e da conquista. O rei D. Pedro II foi forte opositor desta política lusa, articulando-se internamente com os soberanos de Soyo e externamente aliando-se aos holandeses, que assistidos por apoio congolês invadiram e ocuparam Luanda em 1641. Nkanga a Mvika, o D. Pedro II do Congo, muito ativo na política externa nesse contexto, trocou cartas com o Vaticano e o então Rei de Portugal e Espanha, reclamando da conduta do Governador de Angola. Apesar da habilidade diplomática do rei D. Pedro II Ncanga a Mvica no além-mar, sua legitimidade interna não era suficiente para manutenção de sua kanda, originária de Nsundi, no poder, não tendo ela se sustentado por mais de duas gerações, sendo seu ultimo representante Garcia I Mbemba a Ncanga. ${ }^{180}$

O sucessor de Garcia foi Nimi a Ncanga, eleito D. Ambrósio I, e marcou a volta da casa dos Kuilo de Bamba ao poder. Essa intensa rotatividade demonstra a impossibilidade de um grupo se manter no poder por mais de duas gerações, ou do estabelecimento de um sistema de sucessão organizado, capaz de minimizar os conflitos, o que tinha consequências terríveis para o Congo. Os Kuílo tentaram permanecer no poder após a morte de Ambrósio elegendo Neginga a Nimi ainda adolescente. Mas Mpanzo a Nimi, seu irmão mais velho, tomou o poder apoiado por outros partidários, rompendo com sua kanda e fundando a Casa de Mpanzo ou quimpanzo. Mpanzo quando coroado ganhou o nome de D. Alvaro V, tornando-se o primeiro rei de quimpanzo. ${ }^{181}$

Após o aparecimento dos Quimpanzo com a ascensão de Alvaro V, a hegemonia política saiu deixou o eixo: Mbamba - Nsundi, e passou a se dar entre: Quimpanzo e Quinlaza. Os motivos principais para a hegemonização dos quimpanzo e quinlaza é um

\footnotetext{
${ }^{180}$ Thornton e Andrea Mosterman, em artigo recente, apresentaram as relações diplomáticas entre o Congo e os holandeses como elemento essencial para compreendermos as tensões entre o Congo e Luanda no século XVII e a invasão holandesa em Luanda: Mosterman, Andrea e Thornton, John K. A Re-interpretation of the Kongo-Portuguese, p. 235-248. Sobre as disputas políticas internas no Congo: Heywood, Linda e Thornton J. K...Central African Creoles and The Foundation of the Americas, p.135143.

${ }^{181}$ Thornton, John e Heywood, Linda. Central African Creoles (...), p. 139.
} 
tanto incerto. Porém, sabemos que essas duas makanda disputaram o poder em situação de guerra civil até o início do século XVIII. ${ }^{182}$

A origem dos quinlaza foi contemporânea aos quimpanzo e também se deu no contexto das guerras civis. Esta kanda nasceu vinculada a uma das mais importantes personagens da história política congolesa: Ana Afonso de Leão. Rainha Ana foi uma hábil mediadora que viveu no período muito turbulento das ultimas décadas do século XVII, morrendo nos primeiros anos do XVIII. Foi rainha, mas sua atuação principal foi após a morte de seu marido, rei Nessamu a Mbando. Seu irmão Ncanga-a-Mbandu também foi rei: Garcia II, o ultimo "grande" rei do Congo do século XVII, antes da crise política e descentralização Apesar dessas duas importantes figuras, a kanda fundada não carregou o nome dos soberanos: Mbandu e sim derivado de Muene Nlaza, título feminino que carregava D. Ana, por sua posição de mediadora em sua kanda. De Nlaza teria vindo o nome quinlaza. Rainha Ana teria expandido seu poder mediador para além de sua kanda original e fundado uma nova, aglutinando outros aliados. ${ }^{183}$

Com a reunificação do reino, reconquista da capital e o apaziguamento dos conflitos em 1709 com D. Pedro IV, este regulamentou a sucessão como rotativa, estabelecendo que um rei quimpanzo sempre devia ser sucedido por um quinlaza e viceversa. ${ }^{184}$ Como observamos anteriormente, Savona afirmou que ainda em 1775 o sistema rotativo encontrava-se em atividade: ${ }^{185}$

Frei Rafael, uma década depois, foi testemunha da disputa sucessória entre partidários de D. José I Nepaxi Giacana e D. Pedro V Nebica a Vita, ocasião em que não sabia com clareza se Pedro vivia ou não e os missionários tornavam-se alvo das disputas entre Quimpanzo e Quinlaza pela legitimidade do poder. Se entendermos a descrição de Frei Rafael à luz da contextualização da década anterior feita por Savona notamos que houve o rompimento do sistema alternado de sucessão.

Quando Frei Rafael e seu companheiro Pe. André do Couto Godinho chegaram ao Congo já eram aguardados no caminho pela embaixada enviada por D. José I de

\footnotetext{
${ }^{182}$ Toso, Carlo. Relazioni inedite di P.Cherubino Cassinis da Savona, p. 207.

183 Thornton, John K. Elite women in the kingdom of Kongo, p. 455, 456. Rainha Ana é personagem central no livro de Thornton: The Kongolese Saint Anthony. Dona Beatriz Kimpa Vita and the Anthonian moviment, 1984-1706. Bridge press 1998, p. 97-12.

${ }^{184}$ Toso, Carlo. Relazioni inedite di P.Cherubino Cassinis da Savona, p. 207.
} 
Quinlaza. A ignorância dos missionários em relação à situação política congolesa era total ao chegarem ao Congo: nada sabiam sobre guerras e disputas internas. Há tempos os portugueses estavam absolutamente ausentes de S. Salvador, restritos no máximo aos portos e caminhos de escravos. A presença dos missionários era uma rara oportunidade para os administradores e traficantes lusos terem acesso à capital congolesa, como mostramos no capítulo anterior. ${ }^{186}$

Através dos relatos fica evidente que foi dos Quinlaza a iniciativa de requisitar missionários para a diocese. Apenas quando chegaram nas terras do Quinlaza, no reino de Mucondo, localizado no território mais amplo de Bamba (terras da rainha), os missionários percebem que havia um impasse envolvendo o suposto rei e que havia uma divisão política. ${ }^{187}$ Os padres aos poucos iam percebendo que sua presença no Reino atendia aos interesses de uma "parcialidade" específica e sua preocupação de mostrar isenção quanto à questões temporais foi motivo de inquietação e conflitos durante sua temporada de três meses em Mucondo. Vale lembrar do episódio citado no capítulo anterior no qual por meio de uma carta enviada pelos quimpanzo (que ocupavam a corte) aos padres eles souberam que a eleição de D. José I não era consensual. de Vide não informa quem são os opositores, apenas diz que são familiares do antigo, então falecido, rei Pedro V. ${ }^{188}$

Ao contrário do que parecia ao padre, Pedro V não foi o antecessor de D. José I. Recorrendo ao catálogo dos Reis do Congo e frente às informações políticas das fontes, pode-se inferir que Pedro $\mathrm{V}$ tinha sido um rei quimpanzo ${ }^{189}$ que governara antes de Alvaro XI Nepemba a Sunga de quinlaza: este sim antecessor de D. José I. Alvaro XI e os quinlaza assaltaram o poder de Pedro V e seus "parentes" de quimpanzo, que migram

\footnotetext{
${ }^{186}$ Frei Rafael Castello de vide. Viagem e missão no Congo, p. 81, 82.

${ }^{187}$ Frei Rafael Castello de vide. Viagem e missão no Congo, p.. 39-41

${ }^{188}$ Frei Rafael Castello de vide. Viagem e missão no Congo,p. 81, 82.

${ }^{189}$ Uma vez que os Quimpanzo invocavam o nome de Pedro V para se legitimarem no poder concluímos que este era certamente do mesmo partido, por is so sua eleição era legítima de acordo com os critérios de rotação estabelecidas em 1710. Se o sucessor de D. Pedro V e antecessor de D. José I fosse um Quimpanzo legítimo, os mesmos não teriam utilizado D. Pedro V como símbolo de sua legitimidade e sim Álvaro XI. Provavelmente golpe no sistema sucessório tenha se dado justamente por Alvaro XI "Il suo Ré è elletivo da due Famiglie Reali, che si chiamano Quinpanzo una, de Quimulaza l'altra, e alternativamente governo, di manera che morendo il Ré di uma, si elege dell'altra, e così vivono in pace (...) Adesso vi sono solamente due, il primo é deposto, che si chiama D. Pedro Quinto ed il secondo Regna, che hà il nome di Alvaro undecimo".Toso, Carlo. Relazioni inedite di P.Cherubino Cassinis da Savona, p. 207.
} 
e se estabelecem em Mbamba Libota (ou Mbula) com o objetivo de formar uma nova corte e rivalizar com S. Salvador, como testemunhou Savona:

(...) [Pedro V] depois de alguns meses por medo da guerra, em 1764 fugiu com sua pouca gente e a rainha e se refugiou em Bamba Lubota na fortaleza belíssima da pedra de Nzundu e inexpugnável por causa da natureza. Lá, onde se entra por uma estreita gruta quase uma milha, de quatro quilômetros ao redor, com paredes fortíssimas parecia ser feita (...) de maneira que de nenhuma parte se podia entrar se não por aquela estreita gruta. E no meio do terreno passa um riacho abundante de água e alguns poucos peixes para as pessoas que habitam, e não há local de semear frutas. E fizeram uma igreja e colocaram algumas coisas que tiraram da Corte do Congo . E então ele me mandou embaixadores para que eu fosse levantar o hospício e estar com eles, mas eu insisti para que retornassem à sua corte, como fizeram por muitos meses também os eleitores. E ele nunca quis sair de sua fortaleza , chamando outros parentes e amigos e lá está. ${ }^{190}$

Assim como Pedro V e seus partidários que fugiram para Mbamba Libota requisitaram a presença de Cherubino de Savona para a construção de um hospício, uma igreja e legitimarem-se como os regentes do Congo, Frei Rafael Castelo de Vide e Pe. Godinho também foram alvos de disputa entre os quimpanzo e quinlaza. É inegável a legitimidade oferecida pelos religiosos europeus às makanda durante a disputa pelo poder, pois, como veremos, os religiosos eram em si elementos que remetiam ao poder central. Trataremos da relação entre a legitimidade do rei do Congo e os missionários

\footnotetext{
${ }^{190}$ Tradução livre: “dopo porchi mesi per paura di guerra, del 1764 fuggi com poca sua gente, e Regina, e si rifugio in Bamba Lubbota nellaPietra D'Izondo fortezza belíssima, ed inespugnabile fatta dalla natura; Là dove s'entra per uma stretta grotia quase d'um miglio, e dentro hà um gran piano, di quatro miglie in giro, com pareti fortissime, che sembravano fatte (dell'arte) di Maniera che da dessuna parte si puo entrare, se non da quella stretta grotta; e nel mezzo del piano passa um fiumicello abbondante di aqua, e qualche poco di pesce bastante per le paesone che vi dimorano, e vi è sito de la seminare $i$ suo $i$ frutti; e quivi há fato fare uma Chiesa, e posto alcune cose, che porlò via dalla Corte del Congo, e poi mandò Ambasciatori e me, acciò fossi andato a fabricar l'Ospizio, e star com Lui, mà lo l'esortai a tornare ala sua Corte, come fecero per molti mesi anche li Elettori, ed egli mai volle uscire dalla sua fortezza, anzi chiamò altri suoi parenti, e amici, e Là se ne stà." Toso, Carlo. Relazioni inedite di P.Cherubino Cassinis da Savona, p. 207.
} 
mais adiante neste capítulo. Devemos destacar aqui, como sequência à nossa discussão, a importância da chegada dos religiosos em 1781 para a legitimação dos Quinlaza no poder.

A chegada de Frei Rafael e Pe. Godinho ao Congo em 1781 pode ser reinterpretada no contexto dessas disputas internas entre grupos rivais. Os quinlaza de Mucondo apropriaram-se não apenas dos missionários, mas dos diversos elementos católicos que a sua presença legitimava para subjugarem seus rivais Quimpanzo e assumirem o controle da capital do reino. Símbolo da centralização de outrora, S. Salvador oferecia ao grupo no poder o controle sobre o sistema de nomeação de títulos ligados ao cristianismo, entre outras vantagens econômicas e políticas. Domínio este que apenas seria possível com a presença dos religiosos europeus. Pelo relato de Frei Rafael, evidencia-se a participação privilegiada de agentes quinlaza, irmãos de José I (D. Afonso e D. André) na iniciativa de receber os missionários para legitimá-los como sucessores:

Nestes dois irmãos do dito Rei, temos sempre achado grande familiaridade. Estes foram os que em nome do Rei seu irmão, mandaram pedir Padres ao Senhor Bispo, e os que segunda vez mandaram, cujo Embaixador encontrámos em o Rio Loge, como fica dito, e os que nos mandaram buscar a Bamba. ${ }^{191}$

Os representantes da igreja: prelados provinciais, missionários e patrocinadores lusitanos da missão nada sabiam sobre o contexto da política interna congolesa. Em sua sanha em "reestabelecer a parceria" com o rei do Congo via missão católica pouco notaram que os religiosos europeus foram requeridos e utilizados pelos quinlaza como elementos de afirmação e legitimação política, frente aos quimpanzo, num contexto de disputas internas. ${ }^{192}$ É importante compreendermos as motivações internas para a busca de padres, que são essencialmente politicas (porém nunca desvinculadas do aspecto mágico-religioso) e as motivações derivavam de conjunturas especificamente congolesas.

\footnotetext{
${ }^{191}$ Frei Rafael Castello de vide. Viagem e missão no Congo, p. 84.

${ }^{192}$ Frei Rafael Castello de vide. Viagem e missão no Congo, p. 4.
} 
Por isso, ao observarmos este contexto por uma perspectiva demasiadamente atrelada ao prisma europeu da missionação, falhamos em acessar a especificidade da agência histórica e das motivações africanas; e sem estas, pouco compreenderemos.

Através de um olhar interno à política congolesa buscaremos neste capítulo observar aspectos específicos do uso dos elementos católicos como legitimadores de poder centralizado das elites congolesas.

\section{3: D. Afonso I Mvemba a Nzinga e a africanização política do catolicis mo}

Para compreendermos a relação do poder central do Mani Congo com os elementos católicos no século XVIII, é essencial tratar do principal personagem na história política congolesa: Mvemba a Nzinga, coroado em 1509 como D. Afonso I.

D. Afonso I foi o mais notório soberano da história do reino do Congo. Foi batizado na década final do século XV juntamente com seu pai Nzinga a Kuwu e alguns membros selecionados da elite política congolesa. Desde o início D. Afonso destacou-se por seu empenho na incorporação do cristianismo às estruturas políticas congolesas. Segundo fontes contemporâneas, tornou-se um cristão fervoroso, grande conhecedor dos textos bíblicos e da língua portuguesa. Consolidou-se no poder após batalha contra seu irmão Mpanzo a Kitima, na qual Afonso utilizou o cristianismo como argumento principal para legitimação de seu poder, e a mesma estratégia perpassou seu longo reinado de mais de 30 anos. Enquanto esteve no poder, realizou diversos esforços para o letramento e catequese de sua elite, enviou muitos jovens do alto escalão social do Congo para Portugal para se instruir nestes saberes e teve seu filho D. Henrique nomeado bispo em 1518. As cartas que trocou com o rei de Portugal e o Papa também são fontes muito conhecidas pela historiografia.

O evento decisivo da vinculação do poder de D. Afonso aos elementos católicos recém-trazidos pelos portugueses foi a citada disputa da sucessão contra seu irmão Mpanzo a Kitima. Ao contrário de Afonso, Kitima representava a facção da elite congolesa ancorada na tradição política e religiosa. O sistema tradicional de eleição colocava (provavelmente) Kitima como o legítimo rei após a morte de João I Nzinga a Kuwu. Mas Afonso defendeu o catolicismo como justificador de sua legítima sucessão. 
Vejamos a descrição feita por escrito pelo próprio D. Afonso aos "principais senhores do seu reino" e posteriormente enviada ao rei de Portugal D. Manoel II:

E aquele nosso irmão que a sucessão indevidamente e contra a justiça nos ocupava, posto em armas com número infindo de gente, e apoderando-se de todo nosso Reino, o senhorio, o qual quando assim vivos por só salvação de nossa pessoa nos fingimos doente; e estando assim com os nossos, por uma divinal inspiração de nosso Senhor, nos esforçamos, e chamamos os nossos trinta e seis homens, e com eles nos aparelhámos, e nos fomos com eles à praça da cidade, onde o dito nosso Pai faleceu, e onde gente de número infindo estava com o dito nosso irmão, e ali bradámos por nosso Senhor Jesus Cristo, e começámos a pelejar com os nossos contrários e dizendo os nossos trinta e seis homens inspirados da graça e ajuda de Deus, já fogem, já fogem os nossos contários se puzeram em desbarato, e foi por eles testemunhado, que viram no ar uma Cruz branca, e bem aventurado Apóstolo Sant Tago com muitos cavalos armados e vestidos de vestiduras brancas pelejar, matar neles, e foi tão grande o desbarato e mortandade, que foi coisa de grande maravilha. ${ }^{193}$

Mesmo que Afonso tenha afirmado ser ele próprio o sucessor legítimo de seu pai D. João I Nzinga a Kuwu, o fato de serem apenas trinta e seis os seus partidários representa provavelmente um golpe de uma minoria, que assaltou o poder do legítimo (pelas normas vigentes) sucessor Kitima, utilizando não somente um argumento cristão, mas recorrendo a um milagre cristão realizado pelo Apóstolo São Tiago, muito ativo nas batalhas europeias contra os chamados de mouros ou infiéis. Independentemente dos fatos ocorridos na batalha de1509 na praça central de S. Salvador, este relato serve como importante elemento de legitimidade e de justificativa do golpe de D. Afonso I, que a partir dele funda uma nova tradição política congolesa na qual ele próprio passou a figurar como elemento central. A interferência do santo guerreiro foi claramente apropriada da tradição lusa de império sagrado, fundado também (assim como o Congo)

\footnotetext{
${ }^{193}$ Ferronha, António Luís Alves (org). Cartas de D. Afonso Rei do Congo. Lisboa. Comissão pela comemoração dos descobrimentos portugueses, p.21.
} 
em uma batalha contra o infiel a partir de um milagre. O próprio Afonso fez esta relação em seguida na mesma carta:

As quais armas que assim nos enviou significam a Cruz que no céu foi vista, e assim o Apóstolo Sant Tago com todos os outros santos com que por nós pelejou, e sob cuja ajuda de Deus nosso senhor nos deu vitória, e assim também como pelo dito Senhor Rei nos foram enviadas as tomamos como a parte das suas que nas ditas armas meteu, as quais todo poderoso deu nosso senhor pelo seu anjo ao primeiro Rei de Portugal pelejando em batalha contra muitos Mouros, inimigos de sua santa Fé que aquele dia venceu e desbaratou. As quais armas assim pelo dito senhor Rei de Portugal a nós enviada com muita devoção. ${ }^{194}$

Percebe-se assim a apropriação da história mítica da fundação do reino de Portugal do milagre de Ourique, protagonizada por Afonso Henriques no século XIII, primeiro rei de Portugal. Esta história era provavelmente repetida pelos portugueses em contato com autoridades no "Novo Mundo", como argumento retórico para a sua conversão. D. Afonso I reproduziu em solo africano uma fundação mítica semelhante, com a finalidade de tomar o poder e fundar uma nova tradição política ligada a si, acrescentando-se ao fundador mítico de até então: Nimi-a-Lukeni, como observaremos adiante.

É interessante notarmos o papel do escudo de armas, citado por D. Afonso, confeccionado em Portugal, como iconografia que referenciava o milagre compartilhado entre os dois reinos. Este signo para o rei de Portugal significava a vitória da cristandade em terras remotas e a confirmação da vocação imperial e divina de Portugal. Para Mvemba a Nzinga e seus partidários era provavelmente uma insígnia poderosíssima, na qual se via relatada a batalha, argumento maior de sua legitimidade frente ao partido inimigo e perpetuava D. Afonso I como mais importante símbolo político do reino do Congo.

\footnotetext{
${ }^{194}$ Ferronha, António Luís Alves. Cartas de D. Afonso Rei do Congo, p.23-24.
} 
Voltemos ao século XVIII, no qual a tradição da batalha de D. Afonso I aparece nos relatos de Frei Rafael de Vide três séculos depois:

\begin{abstract}
(...)houve também neste Reino no princípio uma coisa memorável, de que há tradição, virem os anjos em defesa do Rei, em uma guerra que the faziam seus inimigos, aparecendo no ar cinco braços, que em um instante mataram todos seus inimigos, pelo que os Reis conservam as suas armas com cinco braços com espadas nas mãos, e Coroa real em cima. O motivo da guerra foi porque o Rei então chamado D. Afonso mandou enterrar viva a sua própria mãe, por não querer abraçar a fé Católica, e os parentes vinham por isto fazer guerra ao Rei; pelo que todos morreram. ${ }^{195}$
\end{abstract}

É interessante notar que a imagem de S. Tiago desaparece nessa versão da narrativa da batalha. Segundo o que Frei Rafael ouviu da tradição dos congoleses, a intervenção do outro mundo se deu por "cinco braços com espadas nas mãos e coroa real em cima" fazendo uma alusão muito clara ao escudo de armas do reino do Congo, feito como presente do rei de Portugal a D. Afonso I. Ou seja, a tradição ibérica do Apóstolo Tiago, dos relatos de D. Afonso teria dado lugar à imagem do próprio escudo de armas do Congo, símbolo da realeza de D. Afonso I.

Se no relato de D. Afonso I ao rei de Portugal um santo católico aparecera como figura central na batalha transformando sua tomada de poder num milagre segundo a tradição católica europeia, nos relatos do século XVIII o próprio Mani Congo tornou-se a figura central da tradição, estabelecendo assim um novo marco e perpetuando-se como principal símbolo do poder centralizado, logicamente vinculado aos elementos católicos que cimentariam o novo referencial político.

O citado escudo de armas não existia apenas nas memórias e tradições orais congolesas no século XVIII, ele existia (e ainda existe) como um grande monumento esculpido em uma pedra na praça central de S. Salvador, como nos informa Frei Raimundo da Dicomano. Essa praça é a provável sede simbólica da batalha ocorrida trezentos anos antes e ainda constituía um dos elementos essenciais da legitimidade do

\footnotetext{
${ }^{195}$ Frei Rafael Castello de vide. Viagem e missão no Congo, p. 39-41.
} 
Mani Congo, como podemos observar na descrição de Frei Raimundo do processo de eleição de um novo rei:

Assim que é eleito [rei], vão buscá-lo e conduzem-no para uma praça onde se prepara uma cadeira, fazem-no sentar, ajoelham-se, pegam num pouco de terra, e esfregam o próprio rosto, batem as mãos, e gritam "Este é o nosso Rei"; e o povo que ali se encontra grita "viva o Rei", e assim se conclui a eleição do Rei; acontece porém muitas vezes que, depois de ser eleito o Rei, chegam mais alguns pretendentes e encontram já eleito o Rei; não ficam satisfeitos e protestam no meio de uma praça, em que está uma grande pedra, na qual estão esculpidas as armas do Rei D. Afonso primeiro, dizendo que não o querem reconhecer como Rei e declaram-lhe guerra. ${ }^{196}$

Nota-se pelo relato de Frei Dicomano que o local da vitória de D. Afonso I não apenas foi conservado como era onde possíveis partidos opostos, descontentes com a eleição do rei, poderiam questionar sua legitimidade, assim como fez o próprio Afonso contra os partidários de seu irmão Mpanzo a Kitima.

Continuemos com o relato da eleição por Frei Raimundo:

Em seguida, a estes se unem outros que fomentam o mesmo partido, e se o Rei eleito quer permanecer no trono, tem de pagar a estes alguma coisa e geralmente tiram-lhe tudo quanto tem, (...) O Rei eleito não pode exercer nenhuma função enquanto não for coroado por um Padre, não pode construir o seu palácio de palha, nem morar no lugar próprio do Rei, pois durante esse tempo é apenas chefe dos Conselheiros. O Rei deve ser sempre escolhido entre os descendentes de uma das três famílias de D. Afonso. ${ }^{197}$

\footnotetext{
${ }^{196}$ Correa, Arlindo. Informação o reino do Congo por Raimundo Dicomano (...), p 8.

${ }^{197}$ Frei Rafael Castello de vide. Viagem e missão no Congo, p. 8-9
} 
A legitimidade do novo Mani Congo, portanto, devia ser assegurada pelo consentimento dos partidos opostos no mesmo local da vitória de D. Afonso I, diante do símbolo maior de sua realeza ("uma grande pedra, na qual estão esculpidas as armas de D. Afonso"), sancionada por um religioso católico europeu.

Parece-nos evidente, diante dos relatos das fontes, a vinculação do poder político do rei do Congo no século XVIII com a figura mítica de D. Afonso I e de elementos do catolicismo (incluindo o próprio missionário) que simbolizavam a tradição política fundada por este soberano no século XVI.

Thornton argumentou pela importância da figura de S. Tiago ao longo do século XVII, vinculada à identidade congolesa. O dia reservado a este santo no calendário cristão: dia 25 de Julho teria sido desde o reinado de D. Afonso I uma espécie de "feriado nacional" congolês, muitíssimo comemorado ao longo do período de grande centralização do poder, assim como no período das guerras civis. ${ }^{198} \mathrm{O}$ fato das celebrações de S. Tiago não terem sido citadas nas fontes do século XVIII não significa, logicamente, que não ocorriam, como no século anterior. Nosso argumento é apenas que D. Afonso I figura como referencial central para a identidade político- religiosa das elites congolesas no século XVIII. Portanto, S. Tiago, o escudo de armas e outros elementos identitários por ele emprestados dos europeus seriam antes desdobramentos do referencial ao soberano do que à sua fonte cristã-europeia. Nossa hipótese é que a celebração do 25 de Julho, que provavelmente continuou no Congo pós-unificação, seria uma celebração da "refundação" mítica pelo rei Mvemba a Nzinga.

Notamos também que o motivo da guerra também aparece ressignificado no século XVIII. Já não era mais a sucessão de Nzinga a Kuwu a razão da disputa entre os irmãos e sim a vingança de Kitima por Afonso ter enterrado viva a própria mãe, que se negara à conversão ao catolicismo. Este suposto assassinato da própria mãe aparece também no relatório de Frei Raimundo de maneira muito semelhante. ${ }^{199}$ Notamos, desta forma, uma interessante ressignificação repleta de simbologias. O suposto assassinato da própria mãe, que não aceitava o cristianismo, é bastante representativo de uma refundação na tradição política. A mãe no Congo era a principal transmissora da

\footnotetext{
198 Thornton, John K. The development of an an African Catholic Church in the Kingdom of Kongo, p. 147-167.

${ }^{199}$ Correa, Arlindo. Informação o reino do Congo por Raimundo Dicomano, p. 1.
} 
identidade e herança do grupo, uma vez que a sociedade congolesa se organizava pela matrilinearidade. Enterrando a própria mãe Afonso estaria simbolicamente rompendo com a tradição precedente.

Tradições de meados do século XVII coletadas por Cavazzi (citadas por Thornton) dão detalhes sobre a narrativa mítica da fundação do reino do Congo por Lukeni. Como observamos anteriormente: Lukeni dia Nimi, significa "Lukeni, o filho de Nimi”. A referência ao pai é importante, uma vez que o poder de Lukeni foi transmitido por ele. Este, porém, almejou romper com o legado paterno e criar um reino próprio. Após a morte do pai, Lukeni confirma-se o novo soberano e rompe com a tradição precedente assassinando violentamente sua mãe. Esfaqueando-a na barriga Lukeni atinge o útero da mãe, onde ele próprio fora gestado, atingindo também o irmão que a mãe grávida carregava. Funda, a partir de então, o Congo, tornando-se o primeiro a portar o título de "Ntinu". 200

Vemos, portanto, a recorrência da mesma simbologia de ruptura e fundação na descrição de Cavazzi sobre Lukeni no século XVII e nas descrições de Dicomano e Rafael de Vide no século XVIII. Os dois heróis fundadores (Lukeni e D. Afonso I) sucedem o poder dos pais, ambos assassinam seus irmãos e suas mães. Portanto, são tradições que simbolizam simultaneamente uma continuidade, pela herança do poder do pai, e de ruptura, representada pelos brutais assassinatos das mães. Vemos que a continuidade se dá na esfera da legitimidade política por transmissão masculina, enquanto a ruptura atinge a figura materna transmissora do vínculo à linhagem. A mãe parecia simbolizar, em ambos os casos, a mais profunda tradição e por isso precisavam ser eliminadas para a construção de uma nova. A marca do poder de Lukeni é a incorporação do novo título "Ntinu", transmissível para sua descendência. Função semelhante teve no caso de Mvemba a Nzinga o título: 'Rei".

No século XVIII vemos, portanto, a preponderância da narrativa de refundação de D. Afonso I nos moldes de Lukeni frente à vinculação tradição cristã-portuguesa da batalha de Ourique, utilizada como argumento por Afonso no século XVI (não sabemos exatamente em que momento entre estes três séculos essas mudanças ocorreram). Isso

\footnotetext{
${ }^{200}$ Thornton citou estas tradições coletadas por Cavazzi com objetivo de recuperar as origens do reino do Congo. Thornton, John K. Origin traditions and history in Central Africa, p. 32.
} 
reforça nossa tese de que o arsenal simbólico português não trouxe um novo modelo de fundação simbólica, apenas deu aporte para que D. Afonso I fosse associado a uma tradição de fundação propriamente congolesa. O vocabulário da realidade cristã europeia, assim como ritos e insígnias cristãos, foram elementos simbólicos manipulados pela agência africana no contexto de transformações políticas internas que se deu, em sua essência, pela repetição de um referencial mítico congolês. Por isso, desconectam-se da origem cristã-europeia, tornando-se referenciais à fundação "mítica" de D. Afonso I Mvemba a Nzinga, que se torna o principal referencial da identidade política congolesa.

\section{4: Títulos nobiliárquicos europeus apropriados}

Não apenas o cristianismo, mas outros elementos da tradição europeia e a própria língua portuguesa foram instrumentalizados pelas elites congolesas como signos de diferenciação social e política, tornando-se também referenciais ao poder centralizado. Os títulos nobiliárquicos do antigo regime português como duque, marques, príncipe, fidalgo e infante foram incorporados desde o reinado de Mpanzo a Nimi (D. Alvaro II) na virada do século XVI para o XVII e continuavam a vigorar durante o período pós-restauração. ${ }^{201}$

Há uma primeira distinção mais importante, entre Infantes e Fidalgos. Na tradição nobiliárquica portuguesa. O título de infante era exclusivo para descendentes diretos do rei, dentre os quais o principal era o príncipe herdeiro. Já fidalgos, contração de "filho-de-algo", referia-se uma aristocracia poderosa, em geral bastante rica, mas não titulada. No período inicial dos batismos no Congo os primeiros usos dos títulos de origem portuguesa pareciam operar por simples tradução. Os soberanos africanos recebiam nomes europeus equivalentes aos seus cargos como soberanos de província. $\mathrm{O}$ Mani Bamba, por exemplo, ganhava também o título de Marquês de Bamba, simples tradução pela identificação da semelhança entre estruturas portuguesas do antigo regime e a congolesa. Entretanto, a partir da internalização destas estruturas, iniciada na primeira década do século XVII, houve uma apropriação dos títulos portugueses pelo

\footnotetext{
${ }^{201}$ Sobre a incorporação de títulos no século XVI: Hilton, Anne. The Kingdom of Kongo, p. 53. Também Thornton, John K, The development of an African Catholic Church in the Kingdom of Kongo, p. 147167.
} 
sistema de organização política local. Num processo que ocorreu ao longo do século XVII, estes títulos passaram a fazer referência a Afonso I. O título de infante, muito restrito no reino português, teve seu uso ampliado no Congo, como nos relatou Frei Raimundo da Dicomano:

Para dar uma ideia destes Infantes, Duques, Marqueses, etc. é preciso saber que o Rei D. Afonso primeiro teve três filhos, dois varões e uma mulher; destes três filhos se fizeram as três familias que agora são consideradas no Congo. Todos os descendentes destes três filhos são chamados Infantes, ainda que a mãe seja escrava, como é o caso do presente Rei. Por isso acontece que no Congo são inumeráveis os Infantes, e não se distinguem dos outros pretos. ${ }^{202}$

É interessante notar a apropriação e ampliação do título vinculado a D. Afonso I, uma vez que foi ele próprio (ao olhar dos europeus) o primeiro infante do Congo, por ser o filho do rei Nzinga a Kuwu. Mesmo tendo sido historicamente incorporado por D. Alvaro II $^{203}$, o conceito de "infante" foi ampliado e ressignificado e passou a vincular-se miticamente a D. Afonso I, como informou Dicomano no excerto anterior.

Os infantes eram os únicos que poderiam receber do rei títulos de duque, marques ou príncipe. Duques e marqueses eram soberanos de Mbanzas: povoações maiores, algumas chegando a ter algumas dezenas de milhares de habitantes. ${ }^{204}$ Cherubino de Savona apresenta números populacionais de diversas províncias com centenas de milhares de habitantes, dados que devemos observar cuidadosamente, pois parecem bastante exagerados: se estivessem corretos a população do Congo teria crescido mais de dez vezes em relação à estimativa de John Thornton para o século XVI. $^{205}$

\footnotetext{
${ }^{202}$ Correa, Arlindo. Informação o reino do Congo por Raimundo Dicomano (...), p8.

${ }^{203}$ Hilton, Anne. The Kingdom of Kongo, p. 53.

${ }^{204}$ Broadhead, Suzan H. Beyond Decline, p. 629

${ }^{205}$ Thornton, John. Elite women in the kingdom of Kongo, p.438. Savona calculou, por exemplo, que em Soyo haveriam na mais populosa província-de China- mais de 400 mil habitantes. No reino todo estimou seis milhões. Sendo que ele teria batizado 700 mil e casado 300 mil. Esses dados são evidentemente exagerados.
} 
De qualquer forma, havia mbanzas bastante populosas no século XVIII, governadas por duques e marqueses. De acordo com Dicomano, o Mani Congo possuía influência apenas na titulação dos infantes, ou seja, a oficialização ritual que confirmava o título, mas este não tinha poder de fato na escolha dos dirigentes das mbanzas de outras províncias, ao menos que fossem diretamente vinculadas à sua kanda. Ou seja, estes governadores de províncias eram nomeados internamente de acordo com regras locais e o Mani Congo era responsável apenas pela nomeação do chefe, que sendo um infante legítimo, poderia ser titulado duque ou marques. Apesar disso, nota-se que o pertencimento a uma das três famílias ligadas a D. Afonso era muitas vezes contestado, causando conflitos entre os candidatos ao trono e aqueles que não os aceitavam como legítimos. Por isso, o poder de nomeação exercido pelo rei tornava-se um critério importante para a confirmação da legitimidade dos soberanos locais. ${ }^{206}$

Discutiremos mais sobre estes infantes no próximo capítulo, que abordará especificamente o poder político local, no qual buscaremos compreender as diferenças entre as diversas titulações, que aparecem de maneira nebulosa na documentação.

Fidalgos, por sua vez, eram aqueles que não eram descendentes diretos de Afonso, porém também podiam ocupar cargos políticos. Por não serem infantes não podiam governar mbanzas, tampouco disputarem eleições reais. Administravam porem libatas: aldeias menores que mbanzas. Havia fidalgos de muito prestígio (por vezes mais ricos e poderosos que muitos infantes) como aquele que Frei Rafael de Vide conheceu em 1786:

Aqui a esta Banza me mandou chamar um Fidalgo grande, não era Infante, mas senhor muito poderoso, porque os Infantes só se chamam aqueles que vêm da descendência dos Reis, que eles na sua língua chamam Muana de Congo e os outros Fidalgos só lhe chamam Mexicongos. ${ }^{207}$

Além de tratar da imponência do fidalgo, Frei Rafael nos informa sobre os títulos em kikongo: Muana Congo e moxicongo. Muana Congo eram os infantes

\footnotetext{
${ }^{206}$ Correa, Arlindo. Informação o reino do Congo por Raimundo Dicomano (...), p8-9.

${ }^{207}$ Frei Rafael Castello de vide. Viagem e missão no Congo, p. 202.
} 
descendentes dos reis, oriundos da descendência de Afonso I. Ou seja, os muana Congo ou infantes eram ligados diretamente à realeza não apenas por descendência, mas por algum tipo de relação de dependência direta ao rei do Congo. A palavra "muana" significa em kikongo "criança" ou "filho", ou seja, muana e infante tem semelhanças significativas em suas línguas de origem.

Os fidalgos, por sua vez, eram apenas moxicongos (nome mais genérico para quaisquer membros da elite política) e por isso mais independentes do rei.

Observando a relação entre os títulos nobiliárquicos portugueses e a tradição afonsina, no século XVIII, notamos que o referencial europeu desses títulos parece supérfluo para os congoleses da época. Era também irrelevante a vinculação desse sistema com o sistema tradicional do antigo regime português. Talvez no primeiro momento, para os reis do Congo fosse interessante utilizar Portugal como referencial de legitimidade do sistema incorporado e adaptado. Mas no século XVIII, esse sistema de nomeação já não fazia mais referência a um sistema europeu. Pelo contrário, referia-se ao mais importante personagem da tradição congolesa: D. Afonso I e por isso era peças essencia para a identidade política coletiva.

Dizer isso não significa afirmar que D. Afonso foi o responsável direto pela africanização destes títulos. Como vimos, foi Alvaro II o primeiro rei de que se tem notícia a usar os títulos nobiliárquicos. ${ }^{208}$ Afonso I passou a figurar como referencial de identidade política, sobretudo após a crise que teve seu marco inicial na guerra de Ambuíla.

John Thornton argumentou que D. Afonso I teria sido o principal adaptador do cristianismo no Congo. Num processo no qual, para ele, teria ocorrido, devido aos esforços deste Mani Congo, uma naturalização nesta religião, dos cultos cristãos e dos elementos do cristianismo, que passaram a permear a estrutura política. Desta forma, o cristianismo tornou-se, para Thornton, uma religião congolesa, com suas especificidades, mas em termos gerais semelhante à maneira como o cristianismo “operava” nas sociedades européias. ${ }^{209}$

\footnotetext{
${ }^{208}$ Hilton, Anne. The Kingdom of Kongo, p. 53.

${ }^{209}$ John K. The development of an an African Catholic Church in the Kingdom of Kongo, p. 148.
} 
Observando o período da segunda metade do século XVIII, concordamos que foi Afonso o responsável pela naturalização do catolicismo, porém não nos parece que os elementos católicos (sobretudo vinculado ao poder político) apareçam desvinculados de D. Afonso I. Ou seja, talvez seja um sistema menos fiel a uma estrutura religiosa católica e mais fiel a um referencial político congolês, que deveu a um soberano específico sua fundação. $\mathrm{O}$ que nos sugere que o catolicismo foi antes uma ferramenta de D. Afonso I para transformar a identidade congolesa do que em si mesmo definidor de uma nova tradição. Em outras palavras, o catolicismo foi apenas um argumento de Afonso I, um elemento simbolicamente associado ao soberano, este sim, referencial definitivo para as estruturas sociais e políticas congolesas.

\subsection{Príncipe e nlumbo: os "reis de fora"}

Dentre os membros da muana Congo, havia títulos de grande prestígio vinculados diretamente à instituição do poder central de S. Salvador. O principal deles era o "príncipe". Este era um título oferecido diretamente pelo rei do Congo para um infante externo à S. Salvador, em geral marquês ou duque de alguma província importante. Na ausência do rei em S. Salvador o príncipe seria convocado para ocupar seu lugar temporariamente. ${ }^{210}$

$\mathrm{Na}$ impossibilidade do príncipe em se dirigir a S. Salvador, deveria ocupar o cargo no caso de ausência temporária do rei o nobre com o cargo chamado nlumbu, descrito pela documentação como "mordomo-mor". ${ }^{211}$

$\mathrm{Na}$ tradição europeia, o Mordomo-mor era o primeiro oficial da Casa Real da Coroa portuguesa, que geria todos os outros oficiais vinculados à mesma, era o oficial de maior importância e mais próximo ao rei português. $\mathrm{O}$ fato de nlumbu ter sido descrito como tal por Dicomano e Rafael de Vide evidencia que este era um título que se dava dentro da kanda do Mani Congo e que este trabalhava próximo ao soberano.

Uma vez que o Mani Congo sofria diversos tipos de restrição à sua livre circulação e aparição pública, regras que visavam protege-lo dos possíveis malefícios

\footnotetext{
${ }^{210}$ Correa, Arlindo. Informação o reino do Congo por Raimundo Dicomano (...), p8, 9.

${ }^{211}$ Correa, Arlindo. Informação o reino do Congo por Raimundo Dicomano (...), p.9.
} 
causados por kindoki ou opositores, o nlumbo parecia cumprir o papel de representante público do rei no contexto interno de mbanza Congo. Este papel fica evidente em sua atuação junto aos missionários, com quem se encontrava levando ordens do Mani Congo, recebendo os missionários em caso de restrição do encontro entre eles. Esses casos de restrição aos encontros pessoais entre o rei e alguns importantes nobres ligados a ele eram comuns, como veremos no caso de Mani Vunda, exposto adiante. Neste sentido o nlumbu parecia ser peça essencial para estabelecer essas ligações, sendo por isso peça essencial do exercício cotidiano do poder central. ${ }^{212}$

Ao contrário do nlumbu, o príncipe deveria ser vinculado a poderes de fora de $\mathrm{S}$. Salvador. Dicomano nos informa de impedimentos no encontro deste com o rei, observados na ultima década do século XVIII (talvez por motivos relativos ao período):

O Rei não pode sair de casa senão em duas ocasiões, isto é, quando há um Padre e quer ir assistir à Missa; então deve avisar os seus Conselheiros, e estes têm de o acompanhar; mas se o Príncipe quer assistir à Missa, então não a pode ouvir o Rei (...). ${ }^{213}$

A concessão do título de príncipe parece ter sido importante para decentralizar o poder da capital e garantir uma transição menos aglutinada em uma mesma kanda ou em um sub-grupo dentro dela. A nomeação do príncipe cabia ao rei e atendia a critérios específicos do período. Sabemos, porém, que o sistema eletivo de sucessão privilegiava o príncipe, ou seja, este era o potencial futuro Mani Congo. Por isso, os critérios para concessão deste título certamente variavam de acordo com as conjunturas das disputas de poder. ${ }^{214}$

De 1710 a 1780, período no qual o sistema rotativo entre quimpanzo e quinlaza parece ter funcionado, é provável que o título de príncipe tenha sido concedido pelo rei para a kanda rival, o que poderia ter sido uma ferramenta para apaziguamento dos conflitos após uma nova eleição. Mesmo após a queda do sistema rotativo em 1781 com

\footnotetext{
${ }^{212}$ O "mordomo-mor" aparece como descrito em Correa, Arlindo. Informação o reino do Congo por Raimundo Dicomano (...), p.9. e Frei Rafael Castello de vide. Viagem e missão no Congo, p. 128 e p. 251.

${ }^{213}$ Correa, Arlindo. Informação o reino do Congo por Raimundo Dicomano (...), p 10.

214 Correa, Arlindo. Informação o reino do Congo por Raimundo Dicomano (...), p8.
} 
a tomada de S. Salvador por Nepaxi a Giacana, que culminou num período de hegemonia dos quinlaza, sabemos pelos relatos de Frei Rafael que o príncipe era um infante de Quibango, um dos principais territórios rivais:

Mas aqui me satisfez o Senhor com outra consolação, recebendo uma carta do Príncipe de Quibango, cheia de piedade e respeito, cuja carta vai inclusa nestes papéis, para que se conheça o desejo de Padres, que tem este Reino. Este Príncipe o é verdadeiramente, ainda que me muitos tomam estes títulos (...). ${ }^{215}$

No caso deste título de príncipe, do qual infelizmente não temos notícia do nome em kikongo, percebemos mais uma ressignificação de um elemento de origem europeia. De fato, não sabemos se este título possuía uma denominação equivalente em kikongo ou se foi um empréstimo da língua e da estrutura política europeia. Também não é possível estabelecermos um período no qual este título foi incorporado e ressignificado. Parece provável que ele tenha ganhado maior importância após a reunificação em 1709, uma vez que o sistema rotativo implantado por D. Pedro IV foi essencial para a estabilidade política, por sua concessão ser um mecanismo de apaziguamento dos conflitos. Pode ser que em períodos de início do século XVI ao início do XVII, período de intensa centralização do poder, este título tenha sido dado aos filhos do Mani Congo, pois era comum que se escolhesse o filho para suceder o pai, como no notável caso de D. Afonso I, filho de Nzinga a Kuwu, ou mesmo dos três Alvaros: Nimi a Luqueni (I), Mpanzo a Nimi (II) e Nimi a Mpanzo (III), na passagem do século XVI para o XVII, que sucederam todos seus próprios pais. ${ }^{216}$

Por isso, nossa hipótese (impossível de ser confirmada) é que este título de origem europeia fora transmitido à moda europeia até o período das guerras civis: dado pelo Mani Congo para seu filho ou o membro de sua kanda preferido para a sucessão, e passou (no período pós-reunificação, após 1709) a ser oferecido para grupos rivais

\footnotetext{
${ }^{215}$ Frei Rafael Castello de vide. Viagem e missão no Congo, p. 197.

${ }^{216}$ Necessidades, Francisco. Factos memoraveis da História de Angola, p. 2 e 3.
} 
como ferramenta para facilitar a alternância e não-acumulação do poder, tornando-se essencial para a manutenção da estabilidade política.

\section{6: Mani Vunda e os espíritos locais}

Um importante personagem da elite política do Congo na segunda metade do século XVIII foi Mani Vunda. Além de possuir grande poder, ele é peça importante na discussão sobre a relação entre o poder político "tradicional" congolês e as práticas que envolviam elementos católicos. Frei Raimundo Dicomano explora minuciosamente a atuação deste chefe:

(...) o Marquês Mani Vunda, que tem o título de Antepassado do Rei, e este tem mais autoridade que o próprio Rei na administração da justiça. Este não pode encontrar-se com o Rei já coroado, porque então o Rei deveria pedir a bênção a este Marquês; cabe-lhe fazer a Coroação e assiste até que o Rei seja colocado no trono e preste juramento, retirando-se depois. Quando morre o Rei, ele fica Regente, e não pode ser eleito Rei. Este Marquês tem maior ou menor autoridade conforme a gente que o segue. ${ }^{217}$

Frei Rafael Também se referiu ao Mani Vunda como "marquês", portanto, ele seria provavelmente um membro do grupo muana Congo, descendente de D. Afonso I e por isso infante titulado. ${ }^{218}$ Mas ao contrário dos outros marqueses, Mani Vunda não era nomeado a partir de uma província ou uma mbanza. Seu título era um importante cargo ligado à realeza e essencial na eleição e na "supervisão" do rei do Congo, além da autoridade máxima na administração da justiça. Mani Vunda era o principal membro do conselho que decidia sobre a eleição de reis, entre outros assuntos. ${ }^{219}$ Este conselho era composto por seis membros. O único conselheiro membro da Muana Congo era o próprio Mani Vunda, do qual era "chefe". Deveria assumir o controle do reino em caso

\footnotetext{
${ }^{217}$ Correa, Arlindo. Informação o reino do Congo por Raimundo Dicomano (...), p9.

${ }^{218}$ Frei Rafael Castello de vide. Viagem e missão no Congo, p. 286.

${ }^{219}$ Correa, Arlindo. Informação o reino do Congo por Raimundo Dicomano (...), p7.
} 
de morte do rei, em seguida convocar e coordenar as eleições do novo soberano. Ele próprio nunca poderia ser eleito rei do Congo, por isso, seu comando era necessariamente provisório, ou imaginário como definiu Frei Raimundo. ${ }^{220}$

Antes mesmo da morte de um Rei, quando o soberano já se encontrava doente, o marquês de Vunda chamava o padre que possuía o título de Vigário Geral do Reino, como ocorreu no caso de Frei Rafael, e o religioso deveria “cantar o responsório [cantos religiosos]" que marcavam o início do processo de eleição. ${ }^{221}$ O Padre então passava a ocupar o cargo de "primeiro conselheiro" e encontrava-se impedido de ver o rei. Então, diante do Mani Vunda e dos outros cinco membros do Conselho fazia um discurso exaltando as qualidades que deveria ter o novo rei a ser eleito. Mani Vunda, então, concedia licença para que o padre preparasse os ritos fúnebres do rei e o enterrasse sempre no segundo sábado após a sua morte. Após o funeral, Mani Vunda reunia os conselheiros e chamava os candidatos interessados. Longe da presença do padre, os seis conselheiros votavam elegendo o novo rei. ${ }^{222}$

É interessante notar, que após presidir a eleição do Mani Congo, e lhe "dar a posse" Mani Vunda assistia à coroação feita pelo o padre e então era obrigado a se retirar, estando impedido de encontrar-se com o rei pessoalmente até o fim de seu governo. Apesar da sua retirada após a coroação e o impedimento de se encontrar com o rei, o poder do Mani Vunda não se restringia ao processo eleitoral. Frei Raimundo relata ocasiões nas quais o Mani Vunda era responsável por decisões de temas importantes para o reino, podendo inclusive revogar decisões do rei. Ele era o juiz supremo dos "negócios de estado". A realização de guerra pelo Mani Congo, por exemplo, estava condicionada à autorização do Mani Vunda e do Príncipe. Nesses casos, devido ao impedimento do encontro presencial com o rei, os encontros se davam em um ambiente especial no qual havia um "buraco na parede" aonde se instalava Vunda e o rei entrava nesta sala para ouvir seu parecer. O Rei, em geral, não poderia dirigir a palavra a ele, apenas ouvia sua decisão e acatava silenciosamente. ${ }^{223}$

O Marquês de Vunda ocupava também o topo da hierarquia judiciária no Congo, na instância da "justiça comum", não apenas em decisões de estado. Poderia intervir

\footnotetext{
220 Correa, Arlindo. Informação o reino do Congo por Raimundo Dicomano (...), p.8.

${ }^{221}$ Correa, Arlindo. Informação o reino do Congo por Raimundo Dicomano (...), p.9.

222 Correa, Arlindo. Informação o reino do Congo por Raimundo Dicomano (...), p.8.

223 Correa, Arlindo. Informação o reino do Congo por Raimundo Dicomano (...), p 10.
} 
principalmente em casos de disputas entre membros da elite. Frei Raimundo nos oferece uma preciosa discrição do funcionamento da justiça e do julgamento de recursos, aparentemente comuns em casos que envolviam disputas no alto escalão da sociedade congolesa:

Cada Senhor de Banza ou Libata tem um macota, isto é um velho chamado Manimpemba ou advogado, e quando surge alguma divergência entre o seu povo, este advogado examina a causa e, ouvidas as partes, decide. Quando sucede haver uma demanda entre dois Senhores, então escolhem um Senhor dos mais potentes para juiz, e na sua presença, e do seu advogado, os advogados dos litigantes defendem a lide do seguinte modo: o Senhor que chamou o outro na presença deste terceiro, que é o juiz, deve ser o primeiro a dizer as suas razões, e apresentar as provas; mas antes de falar, tem de depositar aos pés do juiz e do seu advogado uma quantia em dinheiro (que eu não sei quanto é), ou um porco, ou uma cabra, e depois falar. Quando este acabou de falar, o juiz diz ao outro que venha tal dia para responder, e o juiz com o seu advogado e os velhos comem aquilo que o outro pagou. 224

Em seguida das sentenças e recursos, conforme a descrição de Frei Raimundo, fica evidente a proeminência do Mani Vunda como juiz maior no período:

Dada finalmente a sentença, se não ficam satisfeitos podem recorrer para um dos seis grandes do Reino, deste para o Príncipe, do Príncipe para o Rei, do Rei para o Marquês Mani Vunda, e então já não podem recorrer, e este último tem toda a autoridade para anular até a sentença do Rei. ${ }^{225}$

Ambos os missionários: Frei Rafael de Vide, na década de 1780, e Frei Raimundo Dicomano, dez anos mais tarde, recorreram ao Mani Vunda diante do

\footnotetext{
${ }^{224}$ Correa, Arlindo. Informação o reino do Congo por Raimundo Dicomano (...), p11.

225 Correa, Arlindo. Informação o reino do Congo por Raimundo Dicomano (...), p. 11.
} 
descontentamento frente às decisões do rei. $\mathrm{O}$ caso de Frei Rafael foi relatado no capítulo anterior e dizia respeito ao embate entre o padre e os mobires (ou vilis), traficantes de escravos naturais de Loango que atuavam nos entornos de S. Salvador. Como vimos, os mobires mantinham escravos congoleses em seus quilombos e os repassavam para intermediários que iriam vendê-los para navios ingleses, holandeses e franceses. Frei Rafael, advogando pelo interesse de Portugal, que buscava bloquear essa atividade, recorreu ao conselho do Congo para reclamar da atitude do rei do Congo de ignorar seus pedidos e apoiar os mobires. Neste caso, Frei Rafael ameaçou abdicar do cargo de Vigário Geral e partir definitivamente do reino e para tal pediu licença ao conselho, e o fez com intenção de pressionar o rei D. Antônio II. Os conselheiros se reuniram, presididos pelo Mani Vunda, e decidiram pela permanência de Frei Rafael no Congo, exigindo que o rei tomasse providências para a manutenção do padre. ${ }^{226}$

No caso de Frei Raimundo, em 1795, a interferência de Vunda foi ainda mais direta e descrita com maior minúcia pelo padre. A deliberação era também sobre a partida do missionário do reino. Em ambas as ocasiões percebemos que a partida de um missionário era caso para as altas instâncias judiciais, pois em geral gerava conflito com o rei .

No caso de Frei Raimundo, o rei não aceitava o seu retorno a Luanda, mesmo diante da doença do religioso. Por isso, o padre recorreu ao poderoso marquês:

O Rei com todos os outros não queria dar-me licença para partir, só o Príncipe estava do meu lado, porque eu the tinha dado muitos presentes; então mandei uma porção de aguardente e outras coisas ao Marquês Mani Vunda, para que se não me opusesse, e falasse a meu favor e assim foi. ${ }^{227}$

Adiante, relatou com mais detalhes:

Quando se ouviu a voz do Marquês que, saindo de um buraco daquela parede de palha, dizia que eu não era escravo, e que estando doente

\footnotetext{
${ }^{226}$ Frei Rafael Castello de vide. Viagem e missão no Congo, p.291-292.

${ }^{227}$ Correa, Arlindo. Informação o reino do Congo por Raimundo Dicomano (...), p.10.
} 
podia partir quando quisesse, e que era uma vergonha para a nação Congolesa dizer que um Sacerdote era escravo, sem poder voltar a Luanda quando queria, então acalmaram-se e o Rei concedeu-me a licença. ${ }^{228}$

O Mani Vunda tinha de fato muito poder em relação ao rei e era uma peça fundamental para a administração do poder e da justiça congolesa em fins do século XVIII. Este personagem é particularmente interessante, uma vez que parece exercer um poder paralelo ao poder religioso do padre e político do rei do Congo. Um problema que emerge ao observarmos a atuação e importância do Mani Vunda é a relação deste soberano com o cristianismo; seria a essência da legitimidade do poder deste chefe era paralela ao poder do Mani Congo?

Para compreendermos a relação desta instancia de poder com os elementos católicos e o poder do rei do Congo é importante que resgatemos os debates sobre a origem do poder de Vunda vinculado aos debates sobre as origens do poder político no Congo e do próprio reino.

Jean Cuvelier foi o primeiro a dissertar sobre as origens do reino do Congo, através das já citadas tradições orais coletadas na década de 1930 e 40. As micro histórias das makanda narravam também as origens do Reino do Congo. ${ }^{229}$ Cuvelier relacionou essas tradições com descrições do missionário Cavazzi de Montecúcolo do século XVII com a intenção de reconstruir a narrativa mítica das origens do reino do Congo. Nestas, o herói fundador Nimi a Lukeni, (ou Lukeni dia Nimi) ${ }^{230}$ teria chegado na região do futuro reino e encontrado lá um importante kitomi (sacerdote dos espíritos locais) com o título de Mani Kabunga.

$\mathrm{Na}$ tradição religiosa centro-africana os espíritos da terra tem imensa importância e são agentes diretos na vida social dos homens que habitam aqueles locais. Por isso, Lukeni teria se aliado ou se submetido aos poderes rituais de Kabunga. Assim,

\footnotetext{
${ }^{228}$ Correa, Arlindo. Informação o reino do Congo por Raimundo Dicomano (...), p. 10.

${ }^{229}$ Cuvelier, Jean. Nkutama amnvila za makanda., Congo, Tumba, 1934.

${ }^{230}$ Segundo Thornton o nome Lukeni dia Nimi seria uma referência à origem do herói fundador, uma vez que significa "Lukeni filho de Nimi". Thornton, John K. The origins and early History of the Kingdom of Kongo, 1350-1550”. 200?, p.89-120. Sobre Lukeni também: MacGaffey, Wyatt. Changing Representations in Central African History, Journal of African History, n 46 , Cambridge University Press, 2005, p. 105.
} 
o poder do herói civilizador Lukeni, apesar de conquistador das novas terras, seria de alguma forma sempre dependente do kitome e dos espíritos locais por ele manipulados. Cuvelier, e mais tarde Anne Hilton, associaram o personagem da narrativa mítica kabunga ao Mani Vunda, argumentando ser este o sucessor do kitomi Kabunga. Suzan Broadhead, nos estudo sobre os séculos XVIII e XIX, também influenciada por Cuvelier, definiu Mani Vunda como "successor to the ancient priest of the earth cult". 231

Anne Hilton apresentou uma teoria muito interessante que explicaria o batismo de Nzinga a Kuwu na chave da busca da emancipação do chefe político do Congo em relação ao Mani Vunda. Para Hilton, os ntotila (titulo do soberano congolês) eram dependentes dos kitome, pois por não possuírem poderes mágicos substanciais, ligavam-se a um sistema rígido de dependências de Vunda, ancestrais do kitome Kabunga. A presença dos sacerdotes europeus que se deu nos primeiros contatos, com seu novo repertório ritual católico, era capaz de tornar o Mani Congo independente ritualmente de Mani Vunda. ${ }^{232}$

Thornton problematizou esta tese de Hilton frente às fontes e, na contramão da autora, concluiu que não há nenhuma evidência da relação do Mani Vunda com o a figura mítica de kabunga. $\mathrm{O}$ autor selecionou nas fontes missionárias duas diferentes situações de coroação de reis, em dois momentos temporalmente distintos. O primeiro foi a coroação de Diogo I em 1545 e o segundo em 1622 com a ascensão de Pedro II. Thornton conclui que, nessas ocasiões, Mani Vunda foi um importante personagem político para o processo de eleição, mas argumenta que este não possuía ascensão sobre o rei em aspectos magico-religiosos. Para Thornton, Mani Vunda era um "senhor secular" que, apesar de poderoso, esteve sempre sob tutela do poder do rei. ${ }^{233}$

Observando o contexto do século XVIII através de nossas fontes não é possível optarmos pela defesa total da tese de Hilton ou de Thornton sobre a origem do poder do

\footnotetext{
${ }^{231}$ Broadhead, Susan H, Beyond Decline p.631 e Trade and Politics p 32 cita a descrição de Dicomano para sustentar sua afirmação, mas não há nada nesse relato que o relacione com algum tipo de sacerdote tradicional, Frei Raimundo diz, ao contrário, que Mani Vunda tinha o título de "antepassado do Rei". Correa, Arlindo. Informação o reino do Congo por Raimundo Dicomano (...), p. 9 A autora provavelmente extraiu a ideia de Jean Cuvelier que faz essa relação baseado em fontes etnográficas e no relato de Cavazzi. Cuvelier, Jean, L'Ancién Royaume de Congo. (Bruxelas, 1946)

${ }^{232}$ Hilton, Anne. The Kingdom of Kongo, p.46-69.

${ }^{233}$ Thornton, John K. The origins and early History of the Kingdom of Kongo, 1350-1550”, p.113.
} 
Vunda. Mas, nos parece que a dependência deste ao Mani Congo, pela qual Thornton advoga ("under King's gift" ${ }^{234}$ ) parece questionável para nosso período. ${ }^{235}$

Uma vez que Vunda não pode tornar-se rei e que tampouco pode coexistir no mesmo espaço que o rei (ao menos nos períodos descritos por Dicomano), parece-nos que as esferas de poder simbólico que legitimavam o Mani Congo e o Mani Vunda teriam origens em campos de legitimidade política diversos. Nenhum deles parece estar restrito à dependência do outro no século XVIII. As dependências são mutuas e fundamentais para o funcionamento do sistema político.

A tese de que Vunda poderia simbolicamente estar relacionado ao poder ancestral, da terra, anterior à ocupação política do território por Lukeni parece fazer sentido para o período, mesmo sendo as evidencias muito insuficientes. Ao menos, fariam sentido como uma narrativa mítica que atribuía tal ancestralidade a este personagem. Essa interpretação torna-se mais sugestiva se observarmos o papel ritual do Mani Vunda na iniciação do novo Mani Congo, vinculada à terra:

\begin{abstract}
Assim que é eleito [o rei], vão buscá-lo e conduzem-no para uma praça onde se prepara uma cadeira, fazem-no sentar, ajoelham-se, pegam num pouco de terra, e esfregam o próprio rosto, batem as mãos, e gritam "Este é o nosso Rei’; e o povo que ali se encontra grita "viva o Rei”, e assim se conclui a eleição do Rei(...) $)^{236}$
\end{abstract}

Frei Dicomano enfatizou que Vunda tinha o título de “antepassado do Rei”, e ao mesmo tempo descreve-o como o membro da Muana Congo (infante). Ou seja, ao mesmo tempo em que Vunda deveria pertencer a uma das três famílias que se originaram em D. Afonso I, ele também seria "antepassado" do mesmo. Essa aparente contradição nos leva à hipótese que Mani Vunda seria no plano social ligado à linhagem de Afonso I, ao mesmo tempo em que manipularia forças ligadas aos antepassados das terras (antecedentes de ambos os heróis fundadores Lukeni e D. Afonso I). O poder do

\footnotetext{
${ }^{234}$ Thornton, John K. The origins and early History of the Kingdom of Kongo, 1350-1550”, p. 112-115.

${ }^{235}$ Thornton, John K. The origins and early History of the Kingdom of Kongo, 1350-1550”, p. 113-115.

${ }^{236}$ Correa, Arlindo. Informação o reino do Congo por Raimundo Dicomano, p.6-7.
} 
Mani Vunda poderia de fato emanar de uma fonte de legitimidade política desvinculada de D. Afonso I (e dos reis em geral) e dos elementos católicos.

Em suma, é importante notarmos que a incorporação dos elementos católicos não excluíam necessariamente modos de poder "tradicional" que, como vimos, poderiam estar, em algumas situações, acima do próprio Mani Congo e dos elementos católicos que os legitimava.

\section{7: A Mbanza de S. Salvador e a Legitimidade Política do Mani Congo}

A cidade considerada capital do reino do Congo, onde habitava o rei do Congo e a elite mais próxima dele foi durante o período de centralização de poder um importante referencial simbólico para a identidade política congolesa.

Nos relatos dos primeiros contatos entre portugueses e congoleses em S. Salvador, ocorridos na década de 1490, na ocasião do batismo de João I Nzinga a Kuwu, o nome que aparece para a capital é "Mbanza Congo". Na verdade este é um nome bastante genérico que significava simplesmente, em kikongo: "cidade do Congo", que denota também que esta mbanza era a mais importante politicamente em todo território do Congo. Cada província tinha sua mbanza principal, onde habitava o chefe local, membro poderoso da Muana Congo, que em geral levava o nome da província como Mbanza Soyo, Mbanza Mucondo, Mbanza Bamba.

Mais tarde, o Mani Congo D. Alvaro I (1568-1587), dentre outros esforços para reforçar a identidade católica vinculada politicamente ao ser reino, passou a utilizar, em suas correspondências, o nome português "S. Salvador do Congo" para se referir à sua corte. $^{237}$

Um problema referente às fontes, após Alvaro I, quanto à nomenclatura da cidade é a constante presença do nome em português na documentação. Mesmo nas cartas de autoria dos reis do Congo, observamos a referência à "cidade de S. Salvador do Congo" ou apenas "S. Salvador" nas assinaturas. Por isso, não nos é possível julgar se o nome "S. Salvador" era de uso recorrente entre os congoleses para se referirem à

\footnotetext{
${ }^{237}$ Heywood, Linda e Thornton J. K..Central African Creoles and The Foundation of the Americas, $p$. 170-172.
} 
sua capital. Tampouco é possível sabermos se o nome em kikongo Mbanza Congo continuou sendo utilizado para o período do século XVIII. De fato, nenhuma das fontes disponíveis para o período (correspondências de autoria congolesa ou portuguesa e relatórios de missão) cita "Mbanza Congo" como nome da capital. O que é compreensível, uma vez que se tem um nome mais específico em português não haverá necessidade do uso do nome genérico "cidade do Congo" e não exclui a possibilidade de "mbanza Congo" ter tido uso na oralidade cotidiana no período.

O uso de "Mbanza Congo" para o século XVIII torna-se ainda mais questionável frente ao relato de frei Rafael, que durante um missão pelo marquesado de Mossul faz referência a uma "mbanza de Congo" (entre as mbanzas de Muala e Bube), bastante distante da capital, localizada numa província com alto grau de independência do Mani Congo. ${ }^{238}$

Frei Cherubino de Savona e Raimundo da Dicomano tratam da capital apenas como S. Salvador. Porém, no relato de Frei Rafael de Vide há na primeira citação à cidade algo que nos chama muito a atenção: "Tem sua Corte, chamada Cidade de Bemba de S. Salvador, nela é o assento dos Reis(...)”. ${ }^{239}$

Esta nomenclatura chamou a atenção de Suzan Broadhead, que levantou a hipótese da capital do Congo ter sido chamada de outro nome nos períodos dos séculos XVIII e XIX.$^{240}$ Porém Broadhead, ao contrário de Frei Rafael, diz ser "Mpemba" e através desta transformação consciente no nome presente na fonte, ela oferece uma interpretação interessante: "mpemba" em kikongo significaria "mortos" ("a word for the dead"), nome que a cidade ganhou no por ter sido um local privilegiado no culto aos mortos a partir do século XVIII. Elikia M’Bokolo segue semelhante interpretação (Apesar de não citar Broadhead, tampouco Castelo de Vide) e acrescenta que mpemba também é o termo para cor branca, cor dos mortos. ${ }^{241}$

\footnotetext{
${ }^{238}$ Frei Rafael Castello de vide. Viagem e missão no Congo, p. 35-36.

${ }^{239}$ Frei Rafael Castello de vide. Viagem e missão no Congo, p. 39-41.

${ }^{240}$ M'Bokolo segue a linha de Broadhead apesar de não citá-la claramente. M`Bokolo Elikia. História da África Negra, p. 422, 423.

${ }^{241}$ Broadhead, Suzan H. Beyond Decline, p.631.e M’Bokolo, Africa Negra. História e Civilizações. Tomo I, p.413-430. Chantal Silva também utiliza esta interpretação baseada em M’Bokolo: Silva, Chantal L. Reino do Congo nos séculos XVI a XVIII. Anais do IX Congresso Luso-Afro-Brasileiro de Ciências Sociais. Luanda. 2006.
} 
Acreditamos que esta associação originalmente feita por Suzan Broadheaad é interessantes e condiz, de fato, com a relação da capital com os ritos fúnebres e culto aos mortos, que trataremos adiante. Mas a mudança automática do nome Bemba para Mpemba para que sua tese se encaixe nos parece ousada. Além de que Mpemba é nome também a uma importante província, que juntamente a Mucondo, compõe as chamadas “terras da rainha”, principal entreposto dos quinlaza no século XVIII.

Numa carta de 1785 à diocese Frei Rafael novamente cita a Corte com seu nome kikongo: "Sobre as reflexões que V. Ex. ${ }^{a}$ fez sobre a minha carta que mandei de Bemba são bem fundadas(...)", ${ }^{242}$ Isso reforça a ideia de que não foi um uma opção ortográfica de Frei Rafael, pois o nome se encontra repetido em dois diferentes documentos. Thornton não discorreu sobre o assunto, mas ao tratar da elite reinante a chama de "grandes nobres da corte" ("great nobles of the court") chamados de "bembacasi" a partir de uma fonte do século XVII. ${ }^{243}$ Provavelmente a palavra bembacasi se refira aos "de Bemba", o que reforçaria a ideia de que o nome seria de fato Bemba e não Mpemba, como arriscaram Broadhead e M’Bokolo.

Mesmo sendo questionável a vinculação direta do nome da capital do Congo em kikongo com o culto aos mortos, parece-nos evidente, na segunda metade do século XVIII, a importância de S. Salvador nos ritos fúnebres de membros da alta elite. Chamou a atenção de ambos missionários, Freis Rafael de Vide e Raimundo Dicomano, a grande devoção dos congoleses ao culto aos mortos na capital, sobretudo pela vinculação da reverência aos antepassados com locais específicos, os mesmos que também faziam referência à "cristandade" congolesa. Eram locais privilegiados de culto as ruínas das antigas igrejas de S. Salvador: a "Santa Sé" ou "Catedral" do Congo foi construída em pedra no período do batismo do primeiro Mani Congo. Nossas fontes testemunharam que grande parte de sua estrutura ainda estava conservada nas ultimas décadas do século XVIII. ${ }^{244}$

Outras igrejas parecem ter desaparecido, mas seus terrenos continuaram a ser local de reverência aos antepassados. Essa desvinculação da Igreja física, da presença de imagens, ou mesmo de paredes do culto aos mortos intrigou os padres, que

\footnotetext{
242 AHU, Papeis de Angola, Caixa 70, Doc. 23.

243 Thornton, John K: The origins and early History of the Kingdom of Kongo, p. 114.

${ }^{244}$ Frei Rafael Castello de vide. Viagem e missão no Congo, p. 120. Correa, Arlindo. Informação o reino do Congo por Raimundo Dicomano , p 3.
} 
reconheceram que a escolha das antigas igrejas como locais de culto se dava antes por referência aos mortos ali enterrados sendo secundariamente templos cristãos.

A vinculação do cristianismo ao culto aos mortos foi vista pelos principais autores como uma relação direta. Debatemos no primeiro capítulo as interpretações que chamamos de histórico-cosmológicas de autores como Hilton e MacGaffey. Baseadas em etnologias contemporâneas, estes autores montaram esquemas (ou mapas) estruturais dividindo em esferas separadas o chamado culto aos mortos (antepassados) e as forças emanadas da natureza (chamada por eles de mbumba). Através dessa separação de esferas, identificou-se na documentação que os ritos e insígnias do catolicismo seriam vinculados de maneira privilegiada à esfera dos mortos. Por isso, com maior ou menor aceitação da incorporação do catolicismo esses autores argumentaram que por um processo de traduções culturais, os cultos católicos significariam essencialmente culto aos antepassados no "idioma original" africano. ${ }^{245}$

Vejamos os elementos que nos oferecem as fontes para esta discussão na segunda metade do século XVIII. Frei Rafael descreve os rituais no dia de Finados no ano de 1782 na capital congolesa:

No dia da comemoração dos defuntos, costuma esta gente mostrar uma grande piedade para com os mortos, porque em a noite antecedente, não se ouve mais que cantar o Rosário, por todas as Igrejas, que agora só se podem chamar cemitérios, aonde cada um tem os seus parentes enterrados; e isto toda a noite, e no dia seguinte, se ajunta imenso Povo à missa, e ofício dos defuntos, que eu cantei com os Mestres, ou Intérpretes, e discípulos, que o fazem, ainda que com suas imperfeições; porque é o primeiro empenho que têm em o aprender, depois a procissão, como se costuma, etc. Neste dia trazem muitas esmolas à Igreja pelas almas, e a do Rei é mais avantajada, que

\footnotetext{
245 Hilton, por exemplo, vê diferentes fases da incorporação do catolicismo, sendo que na primeira, com D. João Nzinga a Kuwu, ele é identificado aos culto mbumba, depois é identificado a nkadi mpemba com a queima dos minkisi por D. Afonso e mais tarde passa a ser identificado como culto aos antepas sados, sendo a igreja chamada de mbila. Esta interpretação aparece também no trabalho de Marina de Mello e Souza sobre crucifixos congoleses: Central Africans crucifixes. A study of symbolic translations, p. 97100 .
} 
constam dos seus legumes, e alguns frangos, e zimbro; que eu reparto pelos mestres, e pobres, e fica para nós alguma coisa para nossas necessidades. ${ }^{246}$

Primeiramente é interessante notar que o dia de Finados no calendário cristão parece ter sido data privilegiada para as homenagens congolesas aos seus antepassados. Além disso, os cantos são identificados pelo padre como “cantar o rosário”. Os locais privilegiados de culto eram as próprias igrejas "que agora só se podem chamar cemitérios", o que indica que a referência do local de enterro com o templo católico seja ambígua, pois a presença de imagens de santos, crucifixos e mesmo paredes pareciam irrelevantes em relação aos túmulos de antepassados.

Simultaneamente, o padre e mestres de igreja (clero local) aparecem como importantes intermediários nesses rituais, mais do que as insígnias do templo cristão ao receber "presentes", muito provavelmente como formas de ofertar os mesmos aos mortos. É muito provável que os sacerdotes católicos europeus e locais fossem importantes intermediários na comunicação e culto dos congoleses (ao menos dos membros da elite) com seus antepassados mortos.

Ainda sobre os mestres e intérpretes - que serão tema do capítulo seguinte notamos que estes aparecem no relato acima como personagens centrais nesses cultos: "Mestres, ou Intérpretes, e discípulos, que o fazem, ainda que com suas imperfeições; porque é o primeiro empenho que têm em o aprender(...)" As "imperfeições" notadas na condução ritualística parecem ser especificidades congolesas na homenagem aos mortos, não reconhecida pelo catolicismo europeu de castelo de Vide. Isso reforça a ideia da especificidade desses cultos frente a um suposto "idioma" original congolês, e também frente ao catolicismo ortodoxo europeu.

Apesar da importância dos mestres de interpretes, o religioso europeu era absolutamente relevante no culto aos antepassados, como relatou Frei Raimundo Dicomano, que descreveu mais detalhadamente como se davam ritos fúnebres entre membros das elites:

\footnotetext{
${ }^{246}$ Frei Rafael Castello de vide. Viagem e missão no Congo, p. 167-168.
} 
Resta-lhes ainda um outro vestígio de Religião que é sepultar os mortos nobres nas igrejas de S. Salvador (isto é, naqueles lugares onde antigamente estiveram as igrejas), mesmo que estejam longe, e que tenham de caminhar muitos dias. E não os levam senão quando lá está um Padre, e não têm inimigos pelo caminho; ou quando pelo menos podem juntar bastante gente armada para se defenderem, e por isso é que muitas vezes se sepultam defuntos, que já tinham morrido há oito, dez e mais anos. Quando morre um nobre, põem-no logo num compartimento, fazem-lhe muito fogo em volta e todos os dias de manhã e à tarde, o enfaixam com um pano, e o espremem pouco a pouco para fazer sair todas as humidades que tem, e em poucos dias fica seco, apenas com pele e ossos; então, põem-no numa caixa num canto da casa e cobrem-no de pedras; e conservam-no ali, até que o possam levar para ser sepultado na Cidade de S. Salvador. ${ }^{247}$

Neste relato o papel do padre parece essencial nos rituais fúnebres dos nobres congoleses, que mesmo em locais remotos de S. Salvadior, e com perigo nos caminhos, e alto custo em pessoas, mantimentos e armas (também por isso restrito aos "nobres") se esforçavam em conservar o morto e esperar por anos até que pudessem enterrá-lo à maneira dos grandes nobres, onde provavelmente seriam reverenciados por familiares a maneira do relato anterior de Frei Rafael, tornando-se um elemento de legitimidade política para seu grupo vinculada à capital do reino e ao catolicismo.

É interessante notarmos que, de acordo com ambas as descrições, os nobres enterram seus familiares em locais específicos, onde existiram certas igrejas. É provável que cada grupo tivesse vinculação com uma dada igreja ou cemitério onde estariam seus antepassados (mesmo remotos). Anne Hilton, trabalhando com fontes dos séculos XVI e XVII, defende a vinculação exclusiva do catolicismo com o culto aos mortos nesse período, como já foi exposto no Capítulo I. A partir dessa ideia apresenta um esquema no qual grandes nobres, principalmente reis, construíam em vida igrejas vinculadas a santos padroeiros para que fossem enterrados após a morte. Sua linhagem a partir daí seria vinculada ritualmente ao santo e ao local da igreja construída. ${ }^{248}$ Essa hipótese nos parece um tanto ambiciosa, porém bastante interessante. Thornton não foi tão além, mas

\footnotetext{
247 Correa, Arlindo. Informação o reino do Congo por Raimundo Dicomano, p. 5.

${ }^{248}$ Hilton, Anne.The Kingdom of Kongo, p. 51-67.
} 
também defendeu a estratégia de vinculação das igrejas aos túmulos de antepassados como estratégia por parte dos padres europeus para atraírem fiéis, que para reverenciálos necessitariam do padre e do local cristão como intermediários, por isso, mantinham os mortos enterrados ou mesmo suas "relíquias" expostas nas igrejas. Não esquecendo também da importância de S. Salvador como "relíquia" ela própria, de um período glorioso de centralização política, o que fazia dela um referencial para os Muana Congo. $^{249}$

Voltando aos ritos fúnebres na segunda metade do século XVIII, Frei Raimundo afirmou que, ao chegarem com os mortos em S. Salvador, seus familiares se dirigiam primeiramente à praça em frente da "Catedral" para alguns rituais específicos, vejamos:

Quando chegam com o morto ao Congo, levam-no para uma praça muito grande que fica diante da Catedral; fazem ali muita festa entre os parentes e a gente que o vieram acompanhar; saltam, dançam, cantam canções segundo o seu costume, bebem naquele dia muito vinho de palma ou garapa [bebida alcoólica fermentada feita de milho e mandioca], e quando estão esgotados de cansaço, vão chamar o Padre para the fazer as exéquias, e acompanhá-lo ao lugar onde o querem sepultar e assim embriagados voltam para suas casas. Muitas vezes quando o morto está no buraco, antes de deitar terra, deitam-lhe por cima do corpo vinho de palma; mas nunca soube a razão, se o faziam por superstição ou se o faziam para embriagar o morto depois de estarem eles embriagados, e nestas ocasiões acaba sempre por haver alguma desordem. ${ }^{250}$

$\mathrm{O}$ ritual era dividido em duas partes. Na primeira, sem a presença necessária do padre, eram realizadas danças, batuques e oferendas de comida e bebida ao morto (e provavelmente aos outros antepassados) na praça central de S. Salvador, local da batalha em que Afonso I se consagrou em 1509 e onde se encontra o monumento

\footnotetext{
${ }^{249}$ Ideias expostas numa conferência que o Prof. Thornton deu na atual S. Salvador, Angola no ano de 2007 com o nome de Black Jesus: Christian Art in Eighteenth Century Kongo . O texto não está publicado e me foi cedido generosamente pelo próprio autor. Sua principal fonte para esta afirmação foi o relatório do missionário Andrea da Pavia de 1685, presente nos arquivos da Propaganda Fide em Roma, publicado numa tradução francesa por Jadin em 1970.

${ }^{250}$ Correa, Arlindo. Informação o reino do Congo por Raimundo Dicomano (...), p.5-6.
} 
símbolo de sua consagração: escudo de armas do Congo. Este, como vimos, é um local com vinculação direta ao grande soberano fundador, principal antepassado de todos os Infantes (Muana Congo). Para a segunda etapa do ritual, a presença do religioso europeu tornava-se essencial "para lhe fazer as exéquias" e sepultá-lo no local específico junto aos seus antepassados mais diretos. ${ }^{251}$

Vemos, portanto, que S. Salvador comportava um conjunto de referenciais simbólicos relacionados aos mortos e ao catolicismo vinculados também ao poder do rei e que conferia legitimidade àqueles membros da elite, associada à capital pelos ritos fúnebres e referência a antepassados mortos. Dificilmente um Mani Congo poderia ter legitimidade sem ter seus antepassados enterrados em S. Salvador e como intermediários elementos católicos e o próprio padre, presentes em rituais específicos como este descrito por Frei Raimundo.

O próprio rei do Congo tinha associado ao seu poder o fato de S. Salvador ser local privilegiado para enterro de mortos dos altos escalões da sociedade congolesa. Para poder enterrar seus parentes mortos em S. Salvador, membros das elites locais, sobretudo de parcialidade inimiga ao rei, deveriam ter o consentimento do soberano e pagar tributos ao Rei. O ocorrido com um nobre da província de Quibango (aliado aos quimpanzo) durante o Reinado de Afonso $\mathrm{V}$ de Quinlaza ilustra o privilégio real sobre o culto aos mortos em S. Salvador. Para poder sepultar sua mãe em S. Salvador o dito nobre ofereceu presentes ao Mani Congo e contou com Frei Rafael como intermediário. ${ }^{252}$ Mesmo sem possuir poder direto de cobrança de impostos sobre o território do monte Quibango os Mani Congo no século XVIII tinham o controle do acesso e dos intermediários (cristãos) do culto aos mortos em S. Salvador como instrumento de legitimidade política e de ganhos financeiros. ${ }^{253}$

Vejamos a importância das ruínas de igrejas, associada aos mortos, na retomada de S. Salvador por D. José I e os Quinlaza, na descrição de Castelo de Vide:

Entrámos na dita Corte(...) eu e o P.e Dr. nos encaminhámos logo à Santa Sé, que ainda que caída por terra, quisemos antes ir adorar

\footnotetext{
251 Correa, Arlindo. Informação o reino do Congo por Raimundo Dicomano (...), p.7.

${ }^{252}$ Frei Rafael Castello de vide. Viagem e missão no Congo, p. 215.

253 Correa, Arlindo. Informação o reino do Congo por Raimundo Dicomano (...), p 10.
} 
aquelas santas paredes. O Rei nos seguiu, e um numeroso exército, que ainda ali se achava na Sé. Cantámos alguns louvores de $\operatorname{Deus}(\ldots)^{254}$

Através das evidências apresentadas notamos que a prática cotidiana do poder central no Congo encontrava-se, no século XVIII, ressignificada em relação aos períodos anteriores. Nesse novo contexto as referências idetitárias que remetiam aos períodos de centralização política são constantes e os elementos católicos, desde Afonso I, eram fundamentais para a rememoração deste grande Rei, vinculados também à capital S. Salvador. O culto à ancestralidade era intrinsecamente relacionado com o poder do rei do Congo. Os elementos católicos tornaram-se nesse período peças fundamentais para a conformação da identidade política congolesa.

\section{8. Cavaleiros da Ordem de Cristo e a legitimidade do Mani Congo}

Outro elemento essencial para a legitimação do poder do rei do Congo no período era a nomeação de Cavaleiros da Ordem de Cristo. Referências a este título aparecem com frequência na documentação missionária, pois a atribuição desse título foi uma das funções principais dos padres europeus no Congo durante o século XVIII. Essa nomeação no Congo era um privilégio exclusivo do rei, e a presença de um missionário era imprescindível. Estes dois vestiam simultaneamente o novo Cavaleiro com o traje que apresentava uma grande cruz bordada no peitoral. Tal insígnia proporcionava status diferenciado ao nobre congolês que a possuía. Frei Rafael afirmou que tal prática era "um antigo costume deste Reino" 255 e ofereceu descrições privilegiadas da nomeação na década de 1780:

"No meu ministério de Vigário Geral, armei de Cavaleiro, e professo na Ordem de Cristo, segundo o seu costume, a dois Fidalgos, e ao nosso condutor, que tinha vindo de Angola, a quem o Rei fez a mercê de fazer Cavaleiros, cuja acção se fez na presença do Rei, com grande aparato, segundo pede a terra, e é costume dos Vigários Gerais lhe lançar o Hábito, e tomar o juramento, e ao nosso condutor, além de outras dádivas, fez.

\footnotetext{
${ }^{254}$ Frei Rafael Castello de vide. Viagem e missão no Congo, p. 120.

${ }^{255}$ Frei Rafael Castello de vide. Viagem e missão no Congo, p. 220.
} 
o Rei a tal mercê por ser a maior honra, que aqui se faz só aos grandes Fidalgos, pelos grandes serviços, que havia feito de nos conduzir ao Congo; e estas três mercês primeiras as fez o Rei de graça, quando é aclamado e as mais para diante custam muito bem aos que as querem". ${ }^{256}$

Essa prática teve origem na tradição cavalheiresca da Europa medieval. A "Ordem Militar de nosso Senhor Jesus Cristo" existia como instituição ligada ao Papado. Era uma instituição ativa principalmente nas monarquias ibéricas. Essa ordem foi instituída no ano de 1319 por uma bula do papa João XXII, atendendo a demanda dos reis de Portugal e Castela que reivindicavam uma instituição que substituísse a ordem dos Templários, extinta pelo papado de Clemente V. A Coroa francesa se sentia ameaçada pelo poder "paralelo" dos Templários e requisitou a extinção da ordem. Ao contrário do caso francês, para as Coroas ibéricas, armar cavaleiros constituía uma prática importante para a legitimidade dos reis católicos e para a transmissão desta legitimidade divina. Inicialmente o poder de concessão deste cobiçadíssimo título era restrito, em geral, aos reis e infantes (em sua acepção europeia). Com a expansão marítima portuguesa a ordem de Cristo também se expandiu e se hierarquizou, fazendo de capitães-mores das expedições portuguesas "mestres da Ordem de Cristo", seguidos de toda uma hierarquia subordinada, podendo "armar" novos cavaleiros no contexto de expansão da cristandade no "Novo Mundo", o que remetia ao sentido original dos templários na península ibérica no século XIII, quando cruzados estrangeiros lutaram pela expulsão dos "mouros", ganhando terras e mercês como recompensa. ${ }^{257}$

No início do século XVII os reis do Congo mantiveram a política de apropriação (e ressignificação) de instituições originalmente cristãs europeias, esforço iniciado por D. Afonso I e empreendido com muito empenho por D. Alvaro I (1568-1587). A incorporação da instituição da Ordem de Cristo no Congo se deu nesse contexto, no reinado de Alvaro II, que se apropriou do direito de nomeação de cavaleiros no Congo

\footnotetext{
${ }^{256}$ Frei Rafael Castello de vide. Viagem e missão no Congo, p. 103-104.

257 Coelho, Maria Helena da Cruz. O Fim da Idade Média. in Tengarrinha, José (org) História de Portugal. São Paulo, Edunesp. 2001 p 49-65. E Pereira, Esteves e Rodrigues, Guilherme Dicionário Histórico, Corográfico, Heráldico, Biográfico, Bibliográfico, Numismático e Artístico, vol. I-VII, Lisboa, 1904-1915. Dis ponível online em http://www.arqnet.pt/dicionario/index.html (verbete: Ordem de nosso senhor Jesus Cristo).
} 
por iniciativa própria, sem ao menos esperar a autorização das Coroas ibéricas, que seriam as legítimas transmissoras desta mercê. ${ }^{258}$

Cecile Fromont, estudiosa de fontes materiais, nos informa da constante importação de materiais católicos europeus pelos reis do Congo, vindos de Roma através dos capuchinhos durante o século XVII. Dentre eles, segundo a autora, foi constante a presença de medalhões da Ordem de Cristo, que circulavam entre as elites do Congo. Isso indica que já no século XVII a própria circulação de insígnias católicas referentes à Ordem de Cristo no Congo não dependia exclusivamente da Coroa Portuguesa. ${ }^{259}$

Voltemos à discussão das práticas de nomeação de cavaleiros pelo rei do Congo no século XVIII, através da rica descrição de Frei Raimundo Dicomano:

No Congo há uma Ordem Militar dos Cavaleiros de Cristo, que lhes foi concedida pelo Rei de Portugal. O Rei do Congo não pode criar um Cavaleiro, nem este tomar a Cruz, sem que um Padre tha ponha; estes Cavaleiros não têm Comendas, e consiste apenas em serem considerados Nobres e terem o privilégio de poder pôr muitas cruzes feitas de retalhos de pano de diversas cores no capote ou no pano de palha com que geralmente se cobrem, mas eles ampliam este privilégio e põem destas cruzes no chapéu de sol, nas portas das casas, e o Rei põe-nas também na cadeira em que se senta, e senta-se por cima delas sem vergonha; as mulheres destes Cavaleiros fazem o mesmo que os homens, pondo muitas cruzes nos seus panos. ${ }^{260}$

O poder de nomeação dos cavaleiros era restrito ao rei, na presença de um padre. Essa regalia consistia no usufruto da insígnia da cruz da Ordem de Cristo, e também na multiplicação desse símbolo para diversos outros contextos, estendendo o usufruto da insígnia inclusive para suas mulheres, que bordavam cruzes em seus panos, que se tornavam símbolo de diferenciação social para essas mulheres em suas mbanzas ou

\footnotetext{
${ }^{258}$ Heywood, Linda e Thornton J. K...Central African Creoles and The Foundation of the Americas, p. $135-143$

${ }^{259}$ Fomont, Cecile A. Under the Signe of the Cross in the Kingdom of Kongo: Shaping Images and Molding Faith in Early Modern Central Africa. Phd thesis. Harvard University. 2008, p.89.

${ }^{260}$ Correa, Arlindo. Informação o reino do Congo por Raimundo Dicomano (...), p.5.
} 
libatas. Outra demonstração da importância dessa insígnia para a legitimidade local dos cavaleiros é o fato do símbolo também aparecer nas portas de suas casas, visíveis a qualquer um que circulasse pela mbanza, que estendia o prestígio aos demais ocupantes da casa.

Pelas fontes que dispomos, não é possível determinar se a insígnia da cruz da Ordem de Cristo poderia ser também um elemento "mágico", de proteção às pessoas e suas casas. É possível que sim, uma vez que a ritualização da concessão desse título passava pelas mãos de um padre europeu, considerado um nganga poderoso e intermediário do culto aos antepassados. Além disso, as esferas política e religiosa são dificilmente passíveis de distinção. Mas para além de especulação do poder mágico dessa insígnia parece-nos evidente o papel desta cruz como elemento de distinção social e de privilégios econômicos, como nos relata novamente Frei Raimundo quando trata das leis costumeiras do Congo:

Outro delito é pisar com os pés a cruz dos Cavaleiros. Estes ladrões, que não pensam noutra coisa senão em roubar, têm o costume de fazer na terra uma cruz na estrada, especialmente nos portos onde se passam os rios, nas feiras, nos mercados e nas banzas, de modo a que, passando um forasteiro que não sabe onde está a cruz, lhe põe um pé em cima, logo o atam e o vendem se, ele não tem com que pagar o seu próprio custo. Eu incorri neste delito, porque saltando da barca para terra, não sabendo nada da cruz, pus-lhe um pé em cima e vieram logo a pedir que pagasse; mas o barqueiro defendeu-me dizendo que o Padre não paga mucanos [multa por delito cometido], e eles acalmaram-se; mas penso que se acalmaram porque eu tinha muita gente comigo e eles eram poucos, e eu já tinha pegado num bom bastão nas mãos para lhes pagar. ${ }^{261}$

Neste caso, observamos como o privilegio de reproduzir a insígnia da cruz é expandido ao limite, podendo ser desenhada no chão em locais específicos de passagem de "forasteiros", benefício utilizado para cobrarem tributos desses. Frei Raimundo nos oferece uma visão superficial e indignada dessa prática, uma vez que o significado que

\footnotetext{
${ }^{261}$ Correa, Arlindo. Informação o reino do Congo por Raimundo Dicomano (...), p.13.
} 
atribuía ao símbolo cristão tornava inadmissível tais usos da cruz. É provável que existisse um sistema mais complexo de cobrança de benefícios na esfera local, para além do que temos notícia. De qualquer forma, a tensão relatada nos mostra o alcance que a legitimidade local do Cavaleiro de Cristo poderia gozar. O próprio padre, nessa descrição, por pouco não foi obrigado a pagar mucano ao Cavaleiro, por ter pisado em sua cruz. Nesse contexto, a cruz que trazia o missionário tinha menor importância que a do nobre local. A legitimidade do cristianismo "original" europeu nesse contexto é diminuta se comparada ao poder do portador local da cruz, o que evidencia o enorme prestígio do Cavaleiro no contexto local e o alto grau de africanização do símbolo cruciforme.

Uma vez que a insígnia da cruz era também associada ao Mani Congo, a importância do titulo de Cavaleiro de Cristo como elemento de poder local nos mostra que o soberano figurava como fonte de legitimidade da elite das províncias, como nos relata Pe. Raimundo: “(...) e o Rei põe-nas também na cadeira em que se senta, e sentase por cima delas sem vergonha”.

Sabemos que a cadeira do soberano é na África central ainda hoje importantíssima insígnia de poder, sustentando fisicamente o próprio soberano que nela se senta em momentos específicos de ritualização de sua autoridade. ${ }^{262}$ Por isso, sentarse sobre a cruz, ao contrário do que previa a moral cristã de Frei Raimundo, significava ter a cruz como um dos elementos de sustentação de seu poder, uma insígnia de grande respeito e importância.

O título de Cavaleiro da Ordem de Cristo nos mostra que a cruz, no século XVIII, era uma insígnia que remetia à realeza do Congo e à associação das elites locais ao soberano do Congo, e que esse sistema de transmissão de legitimidade ligado ao reino era peça fundamental para a ritualização cotidiana do poder político. Pelos motivos expostos, a concessão do título de Cavaleiros de Cristo era uma das principais fontes para as receitas do rei e dos conselheiros. Para nomear novos Cavaleiros, junto com o missionário, eram cobrados muitos "presentes", pagos com cabras, galinhas, também tecidos e zimbo, concha usada como moeda. ${ }^{263}$

\footnotetext{
${ }^{262}$ Vansina, J. Art History in Africa, an Introduction to the. New York. Longman. 1999.

${ }^{263}$ Correa, Arlindo. Informação o reino do Congo por Raimundo Dicomano (...), p.9.
} 
Além de fundamental para as finanças reais, a concessão desse título poderia ser um importante instrumento de manutenção da estabilidade política, essencial para apaziguar conflitos e para negociações com partidos rivais. Durante o período em que Frei Rafael foi Vigário Geral, nos reinados de D. José I, D. Afonso V e D. Antônio II diversos nobres rivais aos reis foram nomeados Cavaleiros, e Frei Rafael destacou a maior importância das nomeações de nobre "de outras parcialidades" em detrimento de aliados. Como, por exemplo, no episódio narrado no capítulo anterior no qual Frei Rafael e Pe. André Godinho decidiram interromper todos os exercícios sacramentais e rituais como forma de pressionar D. Antônio II a intervir em seu conflito com o traficante de escravos Bua Lau (o "cachorro doido"), que fora excomungado por vender escravos católicos para mercadores protestantes na costa. O Mani Congo, e os conselheiros de estado, apenas se sentiram de fato ameaçados quando os religiosos se recusaram a participar da nomeação de grandes infantes de Quimpanzo, temendo gerar conflitos com os rivais. ${ }^{264}$

Nota-se, portanto, que a concessão do título de Cavaleiro da Ordem de Cristo era peça fundamental para a legitimidade política local e ao mesmo tempo do poder do rei do Congo. Esse título, juntamente com os títulos de infantes, marqueses, duques e o enterro de mortos na capital eram peças essenciais que criavam elos de dependência entre elites locais e S. Salvador. Elementos do catolicismo, e sobretudo o padre, estão intrinsecamente relacionados a esse sistema, que faz referência à tradição fundada por D. Afonso I. Desta forma os missionários e os elementos católicos ocupam lugar central nessas operações do poder político na segunda metade do século XVIII. [

\subsection{Missionários e o Mani Congo: negociação, conflito e dependência.}

No capítulo anterior, problematizamos a intencionalidade das missões católicas no reino do Congo na segunda metade do século XVIII, patrocinadas pelo império português através da rainha de Portugal D. Maria $\mathrm{I}$ e autoridades temporais e eclesiásticas em Luanda. Através do relatório de Frei Rafael de Vide notamos que "restabelecer a Cristandade" e "renovar a antiga amizade, que sempre houve entre o

\footnotetext{
${ }^{264}$ Frei Rafael Castello de vide. Viagem e missão no Congo, p. 148.
} 
Congo e Portugal, e os Reis de um e outro Reino"265 eram intenções relacionadas e ancoradas em interesses comerciais portugueses. Aliado a tais objetivos, a missão tinha evidentemente sua óbvia intenção "original" de expansão do catolicismo em terras africanas. Os esforços em compreendermos as motivações dos religiosos na produção dos relatórios escritos foram importantes para traçarmos as bases da crítica das nossas fontes.

Neste terceiro capítulo, privilegiamos o olhar para a africanização dos elementos católicos e seus usos nas práticas políticas congolesas. Por isso, devemos empreender o esforço de enxergar o papel dos missionários para além da concepção europeia de expansão da fé e do acesso ao tráfico de escravos. Essa tarefa não é simples, uma vez que as fontes produzidas nos contextos de missão são feitas para serem lidas pelos supervisores das ordens religiosas (no caso de Rafael de Vide), e autoridades eclesiásticas e temporais do império português. Isso faz com que os textos busquem demonstrar às ditas autoridades que o trabalho que se espera do missionário-autor está sendo devidamente cumprido, deixando em segundo plano a perspectiva congolesa e sua importância no contexto local. Por isso, uma análise superficial das fontes poderia fazer-nos concluir que o trabalho missionário era essencialmente autônomo e que a perspectiva europeia sobre a importância e função dos religiosos bastaria para compreendermos sua relação com os congoleses. Conclusão que acabaria por ofuscar a agência e especificidades africanas, nosso principal objetivo.

Pelos motivos expostos, é importante que, para traçar um panorama mais profundo da relação entre os missionários e os reis do Congo, lancemos um olhar atento para as situações de conflito descritas nas fontes. Entendemos que em situações de desavenças e negociações entre a visão dos missionários europeus e das autoridades congolesas sobre o papel dos clérigos europeus no Congo podemos perceber de maneira privilegiada a especificidade africana na relação com o catolicismo e com os religiosos.

Para esta finalidade, os três relatórios missionários que utilizamos tem particularidades próprias. O texto de Cherubino de Savona não nos oferece muitos elementos por ser mais factual, se detendo nas informações geográficas, populacionais e numéricas da missão. Esta fonte será mais útil quando debatermos no capítulo seguinte a relação dos padres com as elites locais. Frei Castelo de Vide, por sua vez, foi o

\footnotetext{
${ }^{265}$ Frei Rafael Castello de vide. Viagem e missão no Congo, p. 4.
} 
missionário que teve relação mais próxima com os três soberanos que reinaram enquanto ocupou o cargo de Vigário Geral do Congo. Além disso, graças à constante presença de outros missionários trabalhando em parceria durante toda sua estadia no reino, Frei Rafael pode se deter mais a S. Salvador, estando por isso mais próximo aos reis, o que gerou mais situações de conflito com estas autoridades. Apesar disso, notamos que os embates e dificuldade no relacionamento com autoridades congolesas são minimizados pelo religioso. $O$ que se justifica pela sua intencionalidade de propagandear a missão para que outros religiosos aderissem à missão africana, como vimos no capítulo anterior.

O contato inicial dos missionários Frei Rafael e Pe. Godinho e o então moribundo Frei João com os Quinlaza aliados de D. José I em Mucondo apresenta o primeiro embate. Ao desejarem seguir viagem ao encontro do rei para esclarecerem se este era de fato o rei legítimo, os missionários ficaram retidos pelos Quinlaza em Bamba. Ficou claro nessa situação que a partir do momento que foram entregues às autoridades congolesas pela comitiva portuguesa, os missionários perderam significativamente sua autonomia. Aqui se evidencia um primeiro momento de sujeição dos missionários em relação às vontades do Mani Congo. ${ }^{266}$

Diversas interdições do rei José I aos padres europeus aparecem no decorrer de seu relato, porém sempre matizando o conflito e apresentando justificativas outras, além da simples deliberação real. Eram constantes as negociações quanto à liberdade de circulação de Frei Rafael e Pe. Godinho para missionar no interior do Congo. No exemplo a seguir vemos as estratégias utilizadas por Frei Rafael para não se sujeitar às vontades das elites ligadas ao Mani Congo:

Eu, vendo que não havia já tanta necessidade de ali [S. Salvador] estarem dois padres, quis tornar ao ducado de Bamba a fazer missão, por temos ali passado com tanta mais pressa. Mas os irmãos do Rei não quiseram, porque nos guardavam, mais do que moça donzela se guarda no Reino [de Portugal]; e tinham medo que nos furtassem porque todos nos queriam; mas isso não foi o que me embaraçou, mas sim o meu companheiro, que chorando me disse, se sentia eu na minha consciência o devia deixar só, estando ele, como estava sempre

\footnotetext{
${ }^{266}$ Frei Rafael Castello de vide. Viagem e missão no Congo, p. 83-86.
} 
com moléstias, o que me enterneceu, e deixei para adiante a missão de Bamba. ${ }^{267}$

Há diversos exemplos de conflitos como este nos quais o missionário, motivado pela expansão da fé para o interior, se confronta com as vontades do Mani Congo, que em geral quer retê-lo em S. Salvador, o que nos faz questionar se de fato a expansão da fé e batismo das populações interioranas (objetivo da missão pela perspectiva europeia) era de fato interessante aos reis do Congo.

Vale lembrar a tese de Elikia M’Bokolo, levantada antes por Anne Hilton, da existência de dois tipos diferentes de relação com o catolicismo: o das elites e o popular. Neste caso percebemos que esses dois "catolicismos" não são apenas distintos, mas poderiam apresentar incompatibilidades no período final do século XVIII, uma vez que a expansão do catolicismo para camadas populares parecia interessar pouco ao Mani Congo frente aos privilégios políticos e financeiros que os ritos católicos conferiam a seu poder. ${ }^{268}$

As missões para o interior do Congo, assim como o trabalho na corte, dependiam de uma estrutura eclesiástica local, além do religioso europeu: mestres de igreja, intérpretes, escravos da igreja e carregadores, como atores essenciais para as práticas ritualísticas cotidianas. Desta forma, os conflitos entre visões de mundo e intencionalidades de católicos congoleses e católicos europeus aparecem nas constantes negociações e conflitos cotidianos. Debateremos com mais vagar esses fascinantes personagens congoleses no capítulo seguinte sobre o catolicismo e o poder local das províncias. Neste momento eles nos parecem importantes como intermediários nas situações de conflito entre o missionário e o Mani Congo.

São constantes no relatório de Frei Rafael momentos de temor ou reprovação dos mestres, intérpretes e escravos da igreja assim que o padre decide missionar por terras inimigas às do rei. É interessante notar que isso ocorre, em geral, nas províncias as quais o Mani Congo não deseja que Frei Rafael frequente. ${ }^{269}$ Ou seja, as vontades do

\footnotetext{
${ }^{267}$ Frei Rafael Castello de vide. Viagem e missão no Congo, p. 43.

${ }^{268}$ Hilton, Anne. Kingdom of Kongo, p. 28. M`Bokolo, Elikia. África Negra, p.423

${ }^{269}$ Exemplos em Frei Rafael Castello de vide. Viagem e missão no Congo, p.252 -253 e 291.
} 
rei e dos agentes católicos locais são em geral convergentes, obviamente devido à autoridade que o Mani Congo exerce sobre eles.

A situação na qual o conflito entre a vontade do Mani Congo e de Frei Rafael ficou mais evidente ocorreu nos primeiros meses de 1787, período do já citado evento do envio da embaixada portuguesa formada por autoridades da colônia de Angola e mercadores de escravos. Esta negociação foi intermediada por Frei Rafael e trouxe ao rei $\mathrm{D}$. Afonso $\mathrm{V}$ dois novos missionários. Em troca foi oferecida aos mercadores lusos uma pequena fatia do comércio de escravos que passava por S. Salvador, comandado por mobires (ou vilis) originários de Loango. A negociação decepcionou o embaixador português que abandonou a negociação. Durante este processo (nos meses finais de 1786) morreu D. Afonso V. Como consequência, os "brancos" e ambundos ainda presentes em S. Salvador foram vistos pelos partidários do rei como responsáveis (sobretudo os ambundos) por sua morte e Frei Rafael, com sua comitiva de missão (carregadores, mestres e interpretes), decidiu partir para Luanda com a justificativa de proteger os "angolanos" de retaliações pelo caminho. ${ }^{270}$

Impossibilitado de fazer o caminho costumeiro até Luanda, passando por Micondo e Bamba (terras Quinlaza), Frei Rafael decide passar por Quende e ser guiado por um novo caminho por um infante de Quimpanzo. Quando estava em Quende com sua comitiva o padre recebeu uma carta dos "da corte", provavelmente dos membros do conselho, uma vez que novo Mani Congo não havia sido eleito, exigindo sua volta com toda a gente para S. Salvador. Ocorre então um impasse e Frei Rafael decide ir contra a ordem de S. Salvador e seguir seu objetivo primeiro. Os escravos da igreja o abandonaram “(...)por medo de algum insulto, que receavam (...)” pois é provável que não quisessem desrespeitar as deliberações do conselho. Neste instante, mesmo sem grande parte de sua comitiva "congolesa" Rafael decide seguir com os de Luanda. Tudo indica que já tinha a intenção de abandonar a missão no Congo definitivamente. ${ }^{271} \mathrm{O}$ momento da morte de Afonso $\mathrm{V}$ e de impasse quanto à sucessão, juntamente com a presença de uma comitiva de lusitanos no Congo, era provavelmente a ocasião mais apropriada que Frei Rafael encontrou para sua "fuga". Quando chegou a Luanda, o

\footnotetext{
${ }^{270}$ Outros exemplos de impedimentos do Mani Congo quanto à missão: Frei Rafael Castello de vide. Viagem e missão no Congo, p. 252-253 e 291.

${ }^{271}$ Frei Rafael Castello de vide. Viagem e missão no Congo, p.265-266.
} 
religioso manifestou ao bispo a intenção de permanecer na colônia portuguesa. Vejamos sua descrição:

Mas, como quando os despachei, me achava bem doente, dando disto parte ao Ex.mo Senhor General, com o Ex.mo Senhor Bispo, estes Senhores compadecidos me mandaram ali gente do Libongo para me levarem para Luanda, no caso que a minha doença continuasse; além disso, tendo eu escrito ao Ex.mo Senhor Bispo o desgosto com que já vivia neste Reino [do Congo], não só pelas minhas moléstias, mas por me parecer não aproveitava nada, e que desejava recolher-me, mas por não me enganar a carne, e sangue, queria que Sua Ex. ${ }^{a}$ me mandasse por obediência, ou pela mesma que ficasse [em Luanda], pois não desejo obrar nada se não debaixo deste santo jugo, o Ex.mo Senhor como tão piedoso Prelado, não me negava o despacho da minha súplica, e como Pastor tão vigilante deste vasto rebanho, fazendo de mim súbdito um conceito mais do que eu mereço, me propunha grandes motivos de utilidade da minha assistência na guarda destas suas ovelhas, no caso de ter alguma saúde, e como Deus então mandava, encolhi os ombros, firmando-me não no que me louvava, mas no báculo da obediência, e me pareceu tornar para o Congo. ${ }^{272}$

O intento de Pe. Rafael foi barrado pelas autoridades de Angola e ele foi enviado de volta ao Congo. Vale notar que essa tentativa de saída do reino marcou o momento em que a relação do religioso com as elites reais (Mani Congo e conselheiros) tornou-se bastante conflituosa. A partir de sua volta ao Congo em 1787 os fatos narrados em S. Salvador são majoritariamente de embates entre o missionário e o novo Mani Congo Antônio II. ${ }^{273}$

Todo esse processo reforça a ideia de que o missionário estava sujeito ao poder e interesses do rei do Congo e dos conselheiros e que a incompatibilidade entre a vontade de trabalharem autonomamente como agentes da igreja europeia e as suas obrigações de fato dentro do sistema político congolês gerou constantes situações de conflitos. Após

\footnotetext{
${ }^{272}$ Frei Rafael Castello de vide. Viagem e missão no Congo, p.274.

${ }^{273}$ Frei Rafael Castello de vide. Viagem e missão no Congo, p.294-306.
} 
retornar ao cargo de vigário geral, Frei Rafael continuou negociando sua partida do Congo e teve o pedido de sua partida negada duas vezes pelos conselheiros congoleses, até ter sido finalmente autorizado a partir $1788 .^{274}$

Observando um conjunto de correspondências entre os missionários do Congo e o então governador de Angola e Barão de Mossâmedes nota-se claramente que há uma tensão quanto à liberação de Frei Rafael, que se dizia bastante enfermo, para retornar a Portugal. Mossâmedes escreve ao missionário contando que uma nau vinda das Índias aportaria no Congo para que fosse resolvido o impasse. Provavelmente essa embarcação continha os "presentes" cobrados pelo Mani Congo para que liberasse a saída do religioso. $^{275}$

Frei Raimundo Dicomano, diferentemente de Rafael de Vide, nos oferece através de seu sucinto relatório uma visão mais crítica quanto à relação do rei do Congo com os missionários católicos na ultima década do século XVIII. Este religioso notou que o papel atribuído a ele dentro do sistema político congolês não condizia com suas expectativas e intenções no trabalho catequético, pois era tratado como um mero agente dos interesses reais, como relatou ao Governador de Angola no ano de 1798:

Se a gente do Congo, Ex.mo Senhor, pede Missionários, não é propriamente porque desejem e queiram ser Católicos, mas pedem-nos apenas por um vil interesse. Porque, tendo um Missionário, sepultamse os mortos, fazem-se Ofícios, armam-se Cavaleiros; e por estas funções eclesiásticas, ganha o Rei, os Conselheiros de Estado, o Príncipe, ou seja Rei de fora, os Mestres, porque estes querem ser pagos.

(...)Estas ridículas utilidades são o motivo por que pedem Missionários, e por que não os deixam partir quando lá estão. E, se estão doentes, ou não podem já trabalhar, estando esgotados, e querem regressar para Luanda, não podem fazê-lo sem antes os cativarem com presentes, algum Senhor poderoso que o ajude e o acompanhe, ou então, que o Ex.mo Senhor Governador de Luanda o mande resgatar

\footnotetext{
${ }^{274}$ Frei Rafael Castello de vide. Viagem e missão no Congo, p.300-306.

275 AHNA A-17-5 Oficios para Angola, fol. 67v. Barão de Mossamades para Fr. Rafael Castelo de vide, Agosto de 1787.
} 
com muitos presentes, e esta é a razão por que muitos ali morrem abandonados. ${ }^{276}$

Frei Raimundo, quando decidiu partir, também encontrou dificuldades para retornar a Luanda. Observamos anteriormente a intervenção do Mani Vunda a favor do missionário após receber seu pagamento. Assim como no caso da partida de Frei Rafael, a de Dicomano apenas foi possível com o consentimento de uma elite política local poderosa, pouco importando o parecer da estrutura eclesiástica europeia que patrocinou sua missão.

De fato, o termo "resgate" foi utilizado na documentação pelo padre Dicomano, o que é bastante sintomático do lugar dos religiosos europeus na estrutura de poder congolesa: "Assim aconteceu quando se tratou da questão do meu resgate. O Rei com todos os outros não queria dar-me licença para partir (...)",. 277

Segundo o dicionário de Raphael Bluteau de 1728 o termo "resgate" no período possuía duas acepções relativas a pessoas: a primeira no caso do resgate de prisioneiros e em segundo lugar: "preço, a somma de dinheyro, que se dá para o resgate de hum escravo". Também aparece como sinônimo de "alforria". ${ }^{278}$

Os paralelos entre a situação de cativos e dos padres no reino não são incomuns numa leitura atenta da documentação. Vejamos outras duas situações nas quais os missionários denunciaram ser tratados como escravos pelas autoridades congolesas. Frei Rafael relata fatos ocorridos em 1786:

Pela morte deste Rei Dom Afonso, cresceram os trabalhos, porque a sua parenteira que correu logo das suas terras, além de afligirem os moradores da Corte, e roubarem com grande ira, queimarem todos os muros e casas do Rei, depois de o enterrarem, até a nós nos afligirem, até quererem queimar as casas dos escravos da Igreja, e roubarem-nos e dizerem que haviam de levar os Padres para as suas terras, porque eram seus, porque os Reis seus parentes nos tinham mandado chamar,

\footnotetext{
276 Correa, Arlindo. Informação o reino do Congo por Raimundo Dicomano (...), p.7.

277 Correa, Arlindo. Informação o reino do Congo por Raimundo Dicomano (...), p.10.

278 Vocábulo "resgate". Raphael Bluteau. Vocabulario Portuguez \& Latino. 1729. Versão virtual disponível em: http://www.brasiliana.usp.br/
} 
dando muitas dádivas; mentiras deles, e por bons modos éramos comprados seus escravos; mas os Infantes destas partes nos têm mandado dar satisfação, e pediram perdão; porque aquelas palavras, que ouvíamos, eles não as disseram, mas alguns moços doidos, etc. ${ }^{279}$

Como já mencionado, Frei Raimundo Dicomano fez observação semelhante sobre a atitude do rei Alvaro XI Necanga a Canga em 1798, que teria afirmado ser ele seu escravo e o mantinha como escravo antes da intervenção de Mani Vunda:

Quando se ouviu a voz do Marquês que, saindo de um buraco daquela parede de palha, dizia que eu não era escravo, e que estando doente podia partir quando quisesse, e que era uma vergonha para a nação Congolesa dizer que um Sacerdote era escravo, sem poder voltar a Luanda quando queria, então acalmaram-se e o Rei concedeu-me a licença. ${ }^{280}$

Em ambas as situações os religiosos são "tratados" como escravos pelo Mani Congo. Na descrição de Frei Rafael observamos o interessante argumento dos parentes de D. Afonso V, ao afirmar que ele seria propriedade dos Quinlaza de Mucondo, pois foram eles que requisitaram sua presença e pagaram os presentes para as autoridades de Luanda para que enviassem o clérigo estrangeiro. Na mesma perspectiva podemos identificar a cobrança de presentes, se não pelo Mani Congo por outras autoridades, para liberação dos missionários. Ora, essa relação de dependência é de fato uma relação de compra e venda, assim como se faz com cativos. Por essa perspectiva, identificamos que de fato é bastante semelhante com uma relação de dependência do tipo escravista.

Provavelmente seja ousado afirmar que os missionários eram "escravos" nos moldes africanos dos Mani Congos em décadas finais do século XVIII. Mas acreditamos ser seguro que a relação de dependência do missionário em relação ao rei era de natureza centro-africana e pouco tinha relação com a posição que os missionários ocupavam em seus territórios de origem. Esse é um exemplo interessante no processo

\footnotetext{
${ }^{279}$ Frei Rafael Castello de vide. Viagem e missão no Congo., p.260.

${ }^{280}$ Correa, Arlindo. Informação o reino do Congo por Raimundo Dicomano (...), p.10.
} 
de "africanização" do catolicismo, no qual os sentidos "originais" europeus são secundários em relação aos interesses e aos agentes históricos africanos.

É pertinente relembrarmos da interpretação oferecida pela historiografia pioneira sobre o reino do Congo do papel dos missionários e da Igreja. O mais radical nesse sentido foi o antropólogo francês Georges Balandier, como debatemos no primeiro capítulo desta dissertação. Para este autor, os missionários que desembarcavam no Congo desde o século XVI poderiam ser considerados agentes proto-coloniais portugueses e o fato das autoridades congoleses aceitarem esta presença em seu território demonstra uma vitória do império português, uma vez que a Igreja teria desestabilizado o poder do Mani Congo sendo fator de desagregação do reino, que facilitou a invasão colonial. $^{281}$ Esta interpretação foi criticada primeiramente por Vansina e posteriormente foi minunciosamente problematizada em trabalhos de Thornton, que ofereceram novas interpretações para as relações entre Portugal e Congo nos séculos XVI e XVII. ${ }^{282}$ Por isso, não cabe criticarmos as ideias de Balandier, já bastante ultrapassadas. Devemos, porém notar que nossos estudos do período da segunda metade do século XVIII, no que tange o lugar do missionário europeu no Congo por uma perspectiva africana, nos possibilita afirmar exatamente o oposto.

No período estudado, o controle do rei do Congo (e outras autoridades políticas) sobre a relação congolesa com o catolicismo parece absoluto. A sujeição dos padres ao Mani Congo num sistema de dependência africano demonstra a primordial gerência congolesa sobre as práticas católicas, frente a uma visão europeia de catolicismo e aos interesses lusos. A presença missionária em décadas finais do século XVIII, ao contrário do que sugeriu Balandier, era alicerce importante do poder do rei do Congo.

Pode-se, portanto afirmar, que os elementos católicos: (insígnias, sacramentos, deidades, missionários, entre outros) possuíam significados particulares e constituíamse como base fundante para o exercício do poder político central do Mani Congo e das elites políticas ligadas a ele. Nesse sentido, os significados de origem europeia eram secundários e sempre submetidos à agência histórica dos congoleses. Por isso, não é possível compreender os complexos processos históricos no Congo setecentista e seu

\footnotetext{
${ }^{281}$ Balandier, G. Daily life in the Kingdosm of Kongo. Meridian books. NY, 1969

282 Vansina, J. Anthropologists and the Third Dimension. Africa: Journal of the International African Institute, Vol. 39, No. 1, (Jan., 1969), pp. 62-68 . Thornton, J K. Early Kongo Portuguese relations: a new interpretation. History in Africa. V 8. African Studies Assiciation. 1981, p.183-204.
} 
fluido sistema político a menos que se compreenda este "catolicismo" como um fenômeno particular e africano. 


\section{Capítulo 4-Catolicismo e Poderes Locais}

Como tentativa de estabelecer marcos cronológicos específicos para a história do reino do Congo, temos buscado ao longo desta dissertação identificar os períodos da sua história politica, num exercício de observar o processo histórico particular a esta sociedade com a maior distância possível dos parâmetros da história europeia. Desta forma, temos tratado o período referente à presente pesquisa como de "pósrestauração", que tem como marco inicial a data de 1709 e a reocupação da capital por Nessambo a Mbandu (D. Pedro IV), que estabilizou politicamente o reino instalando o já citado e discutido sistema rotativo entre as makanda rivais quimpanzo e quinlaza. ${ }^{283}$

A nova ocupação da capital, agora governada por um ntotela (do verbo tota unir) também refunda a relação com as diferentes províncias. Como observamos na introdução desta dissertação, os principais autores (Vansina, Broadhead, Thornton e M'Bokolo) ${ }^{284}$ ao tratarem deste período (em geral de maneira panorâmica), definiramno como "imperial", resgatando as fontes, sobretudo o relato de Cherubino de Savona. Ao contrário do reino do Congo (do século XIV ao XVII), o império do Congo comportaria diferentes graus de dependência com diferentes províncias e em alguns casos uma dependência meramente simbólica ou cultural (porém não menos importante), enquanto em outros locais existiram vínculos bastante diretos.

Observamos no capítulo anterior o sistema de funcionamento do poder central e a importância dos sacramentos e símbolos católicos para a prática do poder no Congo e como elementos vinculados à identidade política da tradição dos Mani Congos.

Neste capítulo lançaremos nosso olhar às províncias e aos poderes locais. Seria ousado propor, através das fontes disponíveis, o exercício de mapear os graus de dependência das diferentes localidades à capital S. Salvador e dar uma resposta acabada para o funcionamento do sistema político que articulava S. Salvador às outras unidades políticas. Este complexo sistema de mútua dependência e autonomia, particular em cada província é descrita de forma fragmentária pelas fontes.

\footnotetext{
283 Thornton, John: The Kongolese Saint Anthony. Dona Beatriz Kimpa Vita and the Anthonian moviment, p. 34 .

${ }^{284}$ M’Bokolo, Elkia. África Negra: História e Civilizações, p. 413-440. Vansina, Jan. Kingdoms of the Savana. . 1966. Broadhead, Susan H. Trade and Politics on the Congo coast. Thornton, John K. Kingdom of Kongo. Civil war and Transition .
} 
Mesmo diante da impossibilidade de oferecer respostas a essa importante questão, acreditamos ser possível desconstruir modelos simplificados e revelar este sistema político congolês do período pós-unificação como algo complexo, fluido e particular. Nosso objetivo será lançar luz sobre algumas das sub-unidades políticas do reino do Congo e sobre alguns dos importantes personagens das elites políticas locais, mantendo nosso foco na relação entre catolicismo e poder.

Vejamos novamente a conhecida introdução de Savona a seu relatório:

“O Reino do Congo, por melhor dizer Império, por que tem vários diferentes reinos e muitíssimas províncias, principados, ducados. Está na etiópia meridional e é quase todo católico". 285

Um grande desafio para o historiador que se debruça sobre os textos da época é lidar com as diversas definições e diferenciações das localidades que compunham o reino do Congo. $\mathrm{Na}$ documentação aparecem principalmente as nomenclaturas, utilizados em situações e localidades diferentes: reinos, províncias, principados, marquesados, ducados. Essas categorias são essencialmente políticas e respondem ao desafio que os missionários encontravam em descrever a complexa organização política congolesa. Além disso, notamos que o principal fator definidor dessas nomenclaturas é também fruto da agência da elite local e não uma simples tradução de nossos informantes. Essas nomenclaturas estavam vinculadas, em geral, aos diferentes títulos que gozavam os diferentes chefes locais, como: duques, marqueses e príncipes.

Savona apresentou uma divisão um tanto confusa, em quatro reinos e vinte e três províncias, descritas uma a uma. Os critérios pelos quais Savona diferencia as categorias reino e província são nebulosos, o que talvez seja reflexo de uma dificuldade do próprio missionário em compreender a organização territorial e política do Congo. ${ }^{286}$ Através dos outros informantes, sobretudo Frei Rafael, que viajou mais e descreveu com maior atenção os interiores, podemos especular sobre tais diferenças.

Parece-nos que aquilo que foi descrito como "reino" por Savona eram territórios vinculados diretamente ao poder central, ou seja, territórios que disputavam eleições de Mani Congo, ativas como nos tempos anteriores às guerra civis, mesmo que S. Salvador

\footnotetext{
${ }^{285}$ Toso, Carlo. Relazioni inedite di P.Cherubino Cassinis da Savona sul Regno del Congo e sue Missioni, p. 207.

${ }^{286}$ Toso, Carlo. Relazioni inedite di P.Cherubino Cassinis da Savona sul Regno del Congo e sue Missioni, p. 207-208.
} 
tenha sido apresentado como um reino entre outros. O termo "província", por sua vez, aparece de forma mais genérica, podendo significar subdivisões de um reino ou mesmo territórios fora dos reinos. ${ }^{287}$ Para além disso, acreditamos ser arriscado tomar o esquema de Savona como referência para mapear politicamente o Congo no século XVIII. As lacunas e simplificações são muitas e o sistema que envolve independência e pertença ao Congo é de fato bastante enigmático.

É importante afirmar que a diferenciação entre poder político simbólico e poder "de fato" do rei sobre as províncias não é algo passível de uma diferenciação simples ou esquemática. Havia algumas localidades, como Soyo, que não sofriam sujeição direta de S. Salvador, mas nota-se que a instituição "reinado do Congo" continuava exercendo enorme importância simbólica para os habitantes de Soyo, assim como o seu soberano continuava influente na corte do Mani Congo. Por isso, não podemos nos iludir e observar apenas os vínculos formais. ${ }^{288}$

Apesar disso, estabeleceremos uma diferenciação em dois níveis de pertença ao reino (ou império) do Congo. Em primeiro lugar, províncias que pareciam participar ativamente da disputa de poder em S. Salvador, governando ou entrando em rivalidade com o poder, dependendo da conjuntura. Estas podem ser divididas basicamente entre quimpanzo e quinlaza, que se não dominavam completamente um ou outro território, ao menos exerciam influências significativas.

As províncias que possuíam relação política mais direta com o reino ou império do Congo eram Mucondo, Mpemba, Mbamba, Oando, Quibango e Bula dia Lemba. Nos relatos missionários essas aparecem ativas nas disputas pelo poder e nas práticas cotidianas do poder do Mani Congo. Apesar de expormos tais localidades na mesma categoria, em relação ao vínculo político, admitimos que elas possuíam diversas particularidades entre si. ${ }^{289}$

Num segundo nível, mais ausentes (ou completamente ausentes) das disputas de poder em S. Salvador estariam: Soyo, Nsundi, Ambuila e Mossul. Defenderemos que, apesar de formalmente independentes, estas províncias ainda constituíam-se como parte do Congo a partir dos critérios de pertença política do período pós-restauração. As elites destas parecem ter continuado a depender do Mani Congo e do sistema político sediado

\footnotetext{
${ }^{287}$ Toso, Carlo. Relazioni inedite di P.Cherubino Cassinis da Savona sul Regno del Congo e sue Missioni, p. 207-214.

${ }^{288}$ Frei Rafael Castello de vide. Viagem e missão no Congo, p. 295.

${ }^{289}$ Justificaremos a afirmação a diante através das fontes a seguir.
} 
em S. Salvador para nomear seus infantes e cavaleiros de cristo; mantiveram suas referências identitárias (principalmente o refundador D. Afonso I), continuaram a enterrar seus mortos de alto prestígio na capital e utilizavam os elementos do catolicismo como ferramentas de ritualização cotidiana do poder, em maior ou menor grau, como veremos.

Consideramos ter existido, num terceiro nível de pertença, localidades absolutamente independentes, possuindo vínculo cultural e linguístico com o Congo. Em alguns casos identificando-se como provenientes do fundador Lukeni dia Nimi, outros reconheciam também D. Afonso I. Não nos aprofundaremos nestes territórios, pois além de escapar ao nosso objetivo central, não teríamos recursos a partir de nossas fontes para fazê-lo. Estes são principalmente ao norte, Loango, Kakongo, e Ngoyo; a oeste Mpango, Mbata e Sosso e ao sul Ndembu.

Como vimos, vigorou no Congo pós-reunificação (a partir de 1709) um sistema rotativo entre as makanda de quimpanzo e quinlaza. Debatemos sobre o significado destes grupos e a imensa fluidez que possuíam no capítulo terceiro deste trabalho. Estes partidos, apesar de se organizarem pela linhagem matrilinear, não eram fixos e tampouco territoriais. Por isso, o trabalho de vincular províncias às makanda de forma fixa é impossível. Porém, através da documentação da segunda metade do século XVIII é possível compreender (de forma geral) como as makanda se distribuíam no governo das principais províncias.

Com exceção de Mbamba e Oando, as principais províncias que disputavam o poder no Congo encontravam-se no entorno de S. Salvador. Ao sul da corte (fazendo limite com o rio Ambriz) nas províncias de Mpemba e Mucondo ("terras da rainha") localizavam-se majoritariamente os quinlaza no período, hegemônicos no poder nos últimos trinta anos do século XVIII. Ao leste encontrava-se a tradicional província de Quibango (comumente chamada de monte Quibango), que aparece nos relatos de Frei Rafael como território dos principais rivais dos quinlaza, este era o mais importante entreposto dos quimpanzo e outros grupos associados a eles como os Agua Rosada. Ao norte (fazendo fronteira com as margens do rio Zaire) encontra-se a extensa Mbula dia Lemba, província sobre a qual possuímos poucas informações no tocante a vinculação política, mas que será importante como um contraponto na relação com o cristianismo. Mbamba e Oando encontravam-se mais distantes da capital, ambas entre os rios Ambriz e Loge. Mbamba, no lado oeste, fazia fronteira com a costa e Oando, ao leste, tinha fronteiras com o rio Nkisi e os Sosso. 


\subsection{Mucondo e Mpemba: as terras da rainha}

As terras da rainha eram compostas principalmente pela província de Mucondo e (mais tarde) Mpemba - Savona denominou a região como "reino de Mucondo". ${ }^{290} \mathrm{Na}$ realidade, os limites entre Mucondo e Mpemba são dificilmente estabelecidos no período pós-restauração, uma vez que o primeiro território passou a dominar o segundo após o golpe dos quinlaza, citado anteriormente.

A capital de Mucondo (Mucondobamba) parecia funcionar como capital do poder de ambas as províncias. Necanga a Canga, antes de tornar-se rei D. Afonso V, foi Marquês de Mpemba, quando seu irmão D. José I era rei. Ambos, segundo frei Rafael, eram originários de Mucondo. O próprio D. Afonso V, quando marquês de Mpemba, parecia passar mais tempo em Mucondo do que em Mbanza Mpemba. Mucondobamba, ao menos durante a década de 1780, parecia exercer também o papel de capital de Mpemba. 291

Apesar desta ligação aparecer nos relatos de Frei Rafael da década de 1780 em diante, Savona nos informa que em períodos anteriores (década de 1760) Mpemba era governado pelos "Romano Leite", associados aos membros da elite dirigentes, não de Mucondo, mas de Mbamba. Sendo o principal dos nobres: D. Alvaro Agua Rosada Romano Leite casado com D. Cristina, filha do Marquês de Mpemba. ${ }^{292}$ Ora, os Agua Rosada foram uma tradicional família da política congolesa, ${ }^{293}$ com origem no monte Quibango e com vínculo com os quimpanzo, aparentados com o Mani Congo D. Pedro IV. Por isso, comparando os contextos descritos por Savona e por Frei Rafael, (vinte anos depois) notamos que Mpemba da década de 1760 era controlado pelos quimpanzo e em algum momento até 1780 foi tomada pelos quinlaza.

Essa virada ocorreu provavelmente em decorrência do já citado golpe dos quinlaza sobre os quimpanzo em 1764, narrado por Savona, no qual D. Alvaro XI Npemba a Sunga (quinlaza) foi nomeado à força no lugar de D. Pedro V (quimpanzo),

\footnotetext{
${ }^{290}$ Frei Rafael Castello de vide. Viagem e mis são no Congo, p. 83-85.

${ }^{291}$ Frei Rafael Castello de vide. Viagem e missão no Congo, p. 83-86.

292 Toso, Carlo. Relazioni inedite di P.Cherubino Cassinis da Savona sul Regno del Congo e sue Missioni, p. 210.

293 Thornton, John K. Elite women in the kingdom of Kongo: Historical perspectives on women's political power, p. 458-459
} 
que fugiu para Mbamba Luvota. ${ }^{294}$ Os quinlaza de Mucondo, descendentes da rainha Ana, (família de Leão), ao tomar o poder em S. Salvador, se apoderaram provavelmente do controle da província de Mpemba, uma vez que era local estratégico entre Mucondo e a corte. Isso explicaria o fato de Mpemba ter sido incluído por Frei Rafael nas chamadas "terras da rainha", em referência à Ana Afonso de Leão, citada no capítulo anterior. ${ }^{295}$

Como apresentado anteriormente, Ana Muene Nlaza Afonso de Leão foi esposa do rei Nessamu a Mbando e era irmã do importante rei Necanga a Mbandu (D. Garcia II). Assumiu o papel de chefe de linhagem, tornando-se influente personagem política no apaziguamento das rivalidades na época de intensa crise do poder central. Como mencionado, sua importância política foi tamanha, que a kanda de quinlaza foi fundada por ela, tomando o seu nome (Nlaza). ${ }^{296}$

No contexto anterior à restauração, Thornton apresenta a importante atuação da rainha Ana, não apenas em Mucondo, mas em diversos territórios vizinhos como, por exemplo, Mpemba. Ou seja, Mpemba era associada aos quinlaza antes da restauração, depois disso foi dominada pelos Agua Rosada (associados aos quimpanzo) e em seguida novamente dominada pelos quinlaza de Leão, tornando-se novamente parte das terras da rainha. ${ }^{297}$ Este exemplo nos mostra a impossibilidade de vincularmos as makanda de maneira fixa a um território específico, pois a geografia do poder no Congo era constantemente redesenhada.

A Rainha Ana Afonso de Leão Muene Nlaza, além de ter fundado a kanda quinlaza, estabeleceu uma tradição de poder feminino nas Terras da Rainha, ao menos em Mucondo, como nos mostrou Savona: "No reino de Mucundo reina sempre uma

\footnotetext{
294 Toso, Carlo. Relazioni inedite di P.Cherubino Cassinis da Savona sul Regno del Congo e sue Missioni, p. 207-208.

295 Thornton, John K. Elite women in the kingdom of Kongo: Historical perspectives on women's political power. Journal of African History, 47, Cambridge University Press. 2006. p. 455, 456. Rainha Ana é personagem central no livro de Thornton: The Kongolese Saint Anthony. Dona Beatriz Kimpa Vita and the Anthonian moviment, 1984-1706. Bridge press 1998, p.97-121

296 Thornton, John: The Kongolese Saint Anthony. Dona Beatriz Kimpa Vita and the Anthonian moviment, p 23-29.

297 Thornton: The Kongolese Saint Anthony. Dona Beatriz Kimpa Vita and the Anthonian moviment, 1984-1706. Bridge press 1998, p. 97-121.
} 
rainha com seus Mani, que é cristã, com todos seus vassalos e se chama Dona Cristina de Quinlaza, é viúva.(...)”. ${ }^{298}$

Mesmo após a morte da rainha Ana, na primeira década do século XVIII, os Mani da região continuaram sujeitos às Muene Nlaza sucessoras da mesma. Estas mulheres, além de comandar os Mani destas "terras da rainha" pareciam continuar exercendo influência, assim com a rainha Ana, sobre o poder central, articulando para que seus maridos, sobrinhos, irmãos, filhos ocupassem altos cargos políticos.

Visto isto, nota-se que o caso das terras da rainha é bastante interessante pois foi uma região fortemente vinculada ao poder central do Congo que, ao mesmo tempo, possuía particularidades em sua tradição política própria. O que nos mostra que a "unidade" política pós-restauração possibilitava a presença de diversas especificidades políticas locais.

\subsection{Grão ducado de Mbamba}

Seguindo das terras da rainha em direção ao sudoeste, passando pelo rio Ambriz encontramos Mbamba, a mais extensa província congolesa. Suas fronteiras aparecem de maneira bastante clara nas fontes, uma vez que ao norte e ao sul era demarcada por dois grandes rios: Ambriz e Loge. Mbamba era uma província costeira e a leste seu território penetrava muito para o interior até Oando . Devido a sua extensão e importância foi denominada pelas fontes de "grão ducado" de Mbamba, contendo por sua vez, diversos "marquesados".

O ducado de Mbamba, apesar de ter sido muito extenso, possuiu (no período) parca concentração populacional. Não é possível mapearmos Mbamba politicamente de forma exata, porém as fontes nos informam sobre ao menos duas localidades quimpanzo, chamadas Mbamba de Congo e Mbamba Luvota (ou Mbamba baixa). Desde o século XVII a região chamada grande Mbamba era dominada pelos Valle das

\footnotetext{
298 Toso, Carlo. Relazioni inedite di P.Cherubino Cassinis da Savona sul Regno del Congo e sue Missioni, p. 207-214.
} 
Lagrimas, um ramo quinlaza ligados aos de Mucondo pela descendência da rainha Ana de Leão. ${ }^{299}$

Mbamba foi um território importantíssimo de passagem ao litoral durante todo o período pós-restauração, pois ligava as províncias ao norte do rio Ambriz com os territórios ao sul do rio Loge, como Mossul e Ambuila e o porto de Ambriz (na foz do rio Loge, sua fronteira sul). Era também enclave entre províncias e estados do interior, como Oando, Mbata, Sosso e o litoral. Além de ter sido passagem quase obrigatória entre Luanda e o Congo e vice-versa. Esse motivo, somado à multiplicidade de posições políticas internas, fazia das terras de Mbamba uma das mais ameaçadoras, sobretudo para os portugueses, afro-portugueses e ambundos que circulavam por ali. Por isso foi muitas vezes descrita como "terra de muitos ladrões". 300

Em ambas as narrativas: de Frei Rafael e de Raimundo Dicomano Mbamba ganha grande destaque, negativamente, pois os nobres de uma sub-região desta província (provavelmente Mbamba Luvota) aparecem como constantes saqueadores do material eclesiástico que era enviado pelo prelado de Luanda para os missionários em $\mathrm{S}$. Salvador. Em certa ocasião, um infante cometeu a ousadia de roubar não apenas o material de culto (vinho, hóstias, velas, imagens de santo) mas também os próprios nlekes (jovens "escravos" da igreja). Nesta ocasião os infantes de Mucondo (irmãos do rei D. José I) realizaram ataques à região para recuperar o material e resgatar os nlekes. 301

Eventos como este, bastante comuns, além dos motivos óbvios do acesso ao material e aos especialistas religiosos, parecem ter sido reflexo da rivalidade politica entre Mbamba Luvota e S. Salvador. A partir da sua consolidação no poder com D. José I e a conseguinte recepção dos missionários, os quinlaza passaram a utilizar os padres como vínculo religioso com Luanda e uma importante fonte de poder político e religioso. Os quimpanzo de Luvota (assim como os de Quibango) buscavam constantemente quebrar esta relação de "monopólio" dos quinlaza sobre os padres. Frei

\footnotetext{
${ }^{299}$ Thornton: The Kongolese Saint Anthony. Dona Beatriz Kimpa Vita and the Anthonian moviment, p. 201-205.

300 Toso, Carlo. Relazioni inedite di P.Cherubino Cassinis da Savona sul Regno del Congo e sue Missioni, p. 207-214. Correa, Arlindo. Informação o reino do Congo por Raimundo Dicomano (...), p.6-7. Frei Rafael Castello de vide. Viagem e missão no Congo, p. 261, 262.

${ }^{301}$ Frei Rafael Castello de vide. Viagem e missão no Congo, p. 141.
} 
Dicomano relata situações nas quais os próprios missionários foram retidos nos caminhos de Mbamba:

(...)os de Bamba, que estão no meio do percurso, manifestaram muitas vezes a intenção de não querer deixar passar os Missionários para o Congo, se antes se lhes não mandam Missionários, como de facto fizeram na última expedição, em que, chegados a Bamba, os retiveram ali por muitos meses, sem os deixar continuar viagem, e por causa disso adoeceram, e regressaram a Luanda, dois dos quais morreram, $\mathrm{e}$ outros dois embarcaram para Lisboa doentes. ${ }^{302}$

Outro possível motivo para os constantes roubos de material de missão em Mbamba é a intensa relação presente nas fontes das suas elites com o catolicismo. Mestres de igreja, secretários e interpretes da língua portuguesa eram numerosos na região, e parte de suas elites pareciam prezar muito a recepção de sacramentos. Frei Rafael destacou a grande "urbanidade" de alguns nobres e a grande alegria em sua recepção em algumas mbanzas. Por outro lado, esta mesma Mbamba, foi a província na qual houve mais reclamações de maus-tratos por parte de frei Rafael. ${ }^{303}$

Vejamos dois exemplos contrastantes que ocorreram no mesmo ano de 1780, quando os missionários Frei Rafael, Frei Libório e André Godinho chegaram ao reino do Congo, vindos de Luanda. Nesta ocasião, passou pelo marquesado de Quindoque ao norte do ducado Mbamba:

(...)gente do seguinte Povo, do qual já nos vinham a esperar, vindo diante um Fidalgo, que morava perto da Corte, e só vinha a esperarnos, e dava saltos de alegria de nos ver, e, sendo moço, se intitulava o Acólito da Igreja, este mandou a sua gente nos levasse sobre seus ombros, e nos deu a notícia que o Marquês de Quindoque, Senhor da

\footnotetext{
302 Correa, Arlindo. Informação o reino do Congo por Raimundo Dicomano (...), p.7.

303 Toso, Carlo. Relazioni inedite di P.Cherubino Cassinis da Savona sul Regno del Congo e sue Missioni, p. 207-214. Frei Rafael Castello de vide. Viagem e missão no Congo, p. 241-242.
} 
vizinha Banza, nos vinha a esperar ao caminho. Chegou, e nos recebeu com grande contentamento, acompanhado de muita gente e instrumentos músicos, e os que vinham tocando se apartaram para uma parte do caminho, e a cada parte, quando passava algum Padre tocavam instrumentos, como no Reino se costuma às pessoas Reais, e passando o último Padre nos seguiram tocando até à Banza, que ficava ainda distante. ${ }^{304}$

Algumas poucas léguas ao norte, ainda no mesmo ducado, os missionários pernoitaram em uma Mbanza próxima às margens do Rio Ambriz na qual o tratamento foi absolutamente diferente:

Com estes maus tratamentos, chegámos a um Povo pequeno, e por ser quase noite não pudemos passar adiante. Ali é indizível o que padecemos e cada um de nós referia o que havia passado no caminho. Neste povo nos meteram em uma pequena casa, aonde não achámos algum abrigo; molhados, tremendo de frio, e de fome, porque em todo o dia não havíamos comido, e foi preciso acender fogo, e pedir por caridade alguma tanga, porque o nosso fato todo estava molhado, e nem isto achámos, pelo que eu vendo um total desalinho, entrei por casa de um preto, e the tirei uma esteira e fogo para a nossa casa. Era noite fechada, a fraqueza muita, e tanta que nos obrigou a comer alguns ovos assados, que era o que mais pronto havia. A noite se passou com trabalho, porque as camas estavam molhadas, e os vestidos, ainda os mais interiores; isto com a indigesta comida $(. . .)^{305}$

Essa grande diversidade na relação com os missionários e o catolicismo que é comumente relatada na documentação a respeito de Mbamba foi fruto das numerosas rivalidades e divisões internas à província. Os conflitos políticos internos se traduziram também nos cultos católicos, que continuavam a ser importantes para as práticas cotidianas das elites políticas locais.

\footnotetext{
${ }^{304}$ Frei Rafael Castello de vide. Viagem e missão no Congo, p. 67.

${ }^{305}$ Frei Rafael Castello de vide. Viagem e missão no Congo, p. 71-72.
} 


\section{$\underline{4.3 \text { Quibango }}$}

Quibango foi um território de grande importância na história política congolesa. Assim como Mbamba, era um território bastante extenso e de posição geográfica estratégica. O centro político de Quibango encontrava-se em terras muito acidentadas; sua capital Mbanza Quibango localizava-se no topo de um grande monte, nascente de cinco grandes rios (dentre eles Mbidizi e Ambriz) que desciam destes montes em diversas direções. Pela importância dos rios na religiosidade congolesa (e africana em geral), este morro era considerado como local privilegiado de comunicação com o mundo invisível. O mesmo ocorria em relação ao cristianismo, tendo sido no século XVII local privilegiado de residência dos padres capuchinhos, que ali construíram seu hospício, que posterirormente fora transferido para Ensuco. O antigo hospício, apesar da ausência de capuchinhos, manteve sua importância no período pós-restauração. ${ }^{306}$

As elites de Quibango cumpriram papel central no processo de reunificação do poder no Congo, uma vez que foi este o território de origem do rei D. Pedro IV Nessama a Mbandu, que antes de ter condições diplomáticas e militares de ocupar $\mathrm{S}$. Salvador fez de Mbanza Quibango sua corte. No período de guerras e desorganização do poder, no qual S. Salvador encontrava-se abandonada, a capital de Quibango assumiu o papel de corte, sendo a cidade de (provável) maior importância simbólica para a identidade congolesa após a capital do reino. ${ }^{307}$

Esta província fora também o território de origem do movimento antoniano e de sua líder Beatriz Kimpa Vita. D. Beatriz adveio de setores das elites do território, tornou-se uma nganga muito poderosa, pois recebia em seu corpo o espírito de Santo Antônio. Encabeçou um movimento politico-religioso que visava a reunificação do Congo e pregava a prática de um cristianismo "original" congolês, sem interferência dos religiosos europeus, que (para ela) insistiam em professar as ideias erradas, incompatíveis com o verdadeiro catolicismo. Os preceitos congoleses revelados por Santo Antônio através dela desmentiam a falsa versão do cristianismo dos padres europeus. Nele, Jesus, a Virgem e os santos eram todos negros e originários do Congo.

\footnotetext{
306 Thornton, John: The Kongolese Saint Anthony. Dona Beatriz Kimpa Vita and the Anthonian moviment, p 36-58.

307 Correa, Arlindo. Informação o reino do Congo por Raimundo Dicomano (...), p.7.
} 
A manutenção da versão falsa europeia, segundo ela, era o principal motivo dos malefícios sofridos pelo Congo no período de guerras civis. ${ }^{308}$

Notamos, portanto, uma convergência de significados especiais que Quibango possuía na unidade congolesa. Este mesmo papel aparece traduzido pelos padres a respeito da proximidade que a sua elite possuía com o catolicismo, constantemente considerada pelos padres como fiel e amante do cristianismo, segundo frei Rafael de Vide: "Quibango, monte memorável pela sua eminência, pelas suas vitórias, e pela sua Cristandade, e por ser raiz de muitos Reis. " 309

Em outro momento de seu relato:

Neste monte de Quibango edificaram primeiro o seu Hospício os Padres Capuchinhos Italianos que ao depois um Rei, que ali morava, por causa de discórdias, que tinha havido neste Reino, recolhendo-se para a Corte levou consigo o Padre, que fundou então o Hospício de Ensuco por ficar mais perto da Corte, e do Superior Capuchinho, que morava também no Convento desta Corte, o que tudo hoje se acha destruído; mas a gente deste monte de Quibango conservou sempre a memória da sua Igreja antiga; e a boa Cristandade que aqueles Religiosos Padres eram costumados a ensinar, e ainda hoje aquela Banza de Quibango é uma como segunda Corte: tem havido ali grandes Príncipes, poderosos Senhores de muitas terras, e muitas Povoações de escravos; e os mesmos Infantes que moram por todos aqueles montes, e vales the são sujeitos, e uns são seus filhos, outros sobrinhos e netos; e nenhum se atreve a fazer coisa alguma contra ele, e é monte de paz por isto. ${ }^{310}$

Seus Muana Congo foram tradicionalmente muito ativos na política central do Congo desde o período do poder unificado. Por isso, as elites de Quibango, no século XVIII, tinham nesses antigos reis importantes ancestrais legitimadores políticos.

\footnotetext{
308 Thornton, John: The Kongolese Saint Anthony. Dona Beatriz Kimpa Vita and the Anthonian moviment, p $36-58$.

${ }^{309}$ Frei Rafael Castello de vide. Viagem e missão no Congo, p. 286.

${ }^{310}$ Frei Rafael Castello de vide. Viagem e missão no Congo, p. 207-208.
} 
Quibango continuou presente nas disputas pelo poder em S. Salvador. Era um território de hegemonia quimpanzo e dos Agua Rosada, família associada a esta kanda. Durante a segunda metade do século XVIII, período de hegemonia quinlaza, foi o mais importante entreposto de oposição à S. Salvador. Por isso, Frei Rafael encontrou dificuldades em missionar nesta região, sempre sofrendo pesadas restrições de D. José I e D. Afonso V para sua viagem e estadia no território adversário. ${ }^{311}$

Essas disputas no campo político, e consequentemente no campo cristão, se traduzem na grande quantidade de cartas que este padre relatou ter recebido dos nobres deste monte. Uma destas foi incluída pelo próprio padre em seu relatório ao bispo de Angola e por isso, tivemos acesso a ela. Discutiremos este instigante documento à frente, quando tratarmos do letramento das elites e dos secretários congoleses.

Diante do que foi exposto, nota-se a importância de Quibango na composição do reino do Congo. As elites deste "principado" tinham sua legitimidade intimamente vinculada à tradição política congolesa e por isso ritualizavam esta pertença cotidianamente através de elementos do catolicismo.

\subsection{Mbula dia Lemba e Nsundi}

As províncias de Mbula (ou Lemba) e de Nsundi localizavam-se ao norte de S. Salvador, às margens do rio Congo, que constituía a fronteira norte do território congolês. Encontravam-se muito próximas, portanto, de Ngoyo, Kakongo e Loango.

Por isso, teve em seus territórios a constante presença de vilis ou mobires, que transportavam escravos do interior aos mercadores franceses, ingleses e holandeses nos os portos de Mpinda (em Soyo), Cabinda (em Ngoyo), Malemba (em Kakongo) e Loango. Estas províncias aparecem descritas principalmente por esta característica comercial e pela proximidade aos vilis. ${ }^{312}$

Algo que chamou também a atenção dos missionários a respeito e Mbula e Nsundi foi o pouco interesse dos moradores nas práticas católicas. Savona e Frei Rafael relatam que estes territórios eram dominados no âmbito religioso pelo "gentilismo" e práticas rituais tidas por eles como diabólicas. Estas conclusões não

\footnotetext{
${ }^{311}$ Frei Rafael Castello de vide. Viagem e missão no Congo, p. 295.

312 Toso, Carlo. Relazioni inedite di P.Cherubino Cassinis da Savona sul Regno del Congo e sue Missioni, p. 208 e Frei Rafael Castello de vide. Viagem e missão no Congo, p. 144-145.
} 
derivavam apenas da observação dos padres, mas principalmente de mestres e intérpretes originários de outras províncias, que manifestavam sua "repugnância" em circular por Mbula e Nsundi. ${ }^{313}$ O fato dos próprios congoleses, vindos de S. Salvador ou Mucondo, considerarem os habitantes de Mbula e Nsundi "feiticeiros" pode apontar para a proximidade religiosa destas províncias ao norte com os mobires, que eram igualmente tidos por gentios.

Apesar de terem sido culturalmente aparentados ao Congo, os mobires, em geral não tinham relação com o catolicismo. Eram membros de um tipo específico de seita, semelhante às que no Congo eram chamadas de kimpassi, pertencendo a comunidades rituais iniciáticas chamadas de Lemba. Como especialistas no trato de escravos, os vilis necessitavam de ritos específicos para neutralizar os possíveis malefícios causados pelo desequilibrio que a venda de humanos poderia trazer. Por isso, além de especializados na atividade comercial deveriam também ser especialistas rituais destes cultos lemba, que visavam neutralizar as aflições. ${ }^{314}$

O envolvimento das elites de Nsundi e Bula com os mobires e com o tráfico pode te-los aproximado religiosamente dos vizinhos do norte. Pois, como citado anteriormente, as sociedades Lemba além de rituais, cumpriam também papel regulador do comércio e das rotas, podendo também ser difundida para congoleses do norte ligados comercialmente aos vilis. ${ }^{315}$

É evidente que Nsundi e Lemba não foram as únicas regiões tidas como "gent11icas" e que os mestres, companheiros de frei Rafael, temiam adentrar. Por isso, esta é uma ideia um tanto especulativa, porém provável. ${ }^{316}$

O grau de dependência ou de ligação destas províncias com S. Salvador no período é incerto. Nsundi foi um tradicional território do reino até meados do XVII. Mvemba a Nzinga foi marquês de Nsundi antes tornar-se o prestigiado rei D. afonso I. Sabemos que os chefes de Nsundi participaram ativamente nas disputas de poder no Congo até finais do século XVII. Na década de 1640 o importante e hábil Mani Congo Pedro II Necanga a Mvika, originário desta província, fundou a partir de si uma nova

\footnotetext{
${ }^{313}$ Frei Rafael Castello de vide. Viagem e missão no Congo, p. 145-149.

${ }^{314}$ Thornton, John: The Kongolese Saint Anthony. Dona Beatriz Kimpa Vita and the Anthonian moviment, p. 100-101.

${ }^{315}$ Dias, Jill R. Novas identidades africanas em Angola no contexto do comércio atlântico, p. 318-326.

316 Exemplos em Toso, Carlo. Relazioni inedite di P.Cherubino Cassinis da Savona sul Regno del Congo e sue Missioni, p. 208 e Frei Rafael Castello de vide. Viagem e missão no Congo, p. 190-191.
} 
kanda originária de Nsundi que levava o nome do soberano (kinganga), mas a sucessão destes reis foi interrompida após Garcia I Mbemba a Ncanga. ${ }^{317}$ Após a restauração por Pedro IV em 1709 e a migração das rivalidades para as províncias centrais (Mucondo, Mpemba, Mbamba e Quimbando) Nsundi parece ter saído de cena e deixado de participar das disputas pelo poder.

Sobre a vinculação política de Mbula dia Lemba, não dispomos de informações relevantes nas fontes. Savona e Frei Rafael missionaram nestas terras, porém destacaram apenas a questão do "gentilismo" e do trato de escravos com os vilis no curso do rio Zaire. ${ }^{318}$ Savona nos oferece apenas uma pista quando classifica Mbula como um dos quatro reinos. ${ }^{319} \mathrm{O}$ que indica que, ao menos na década de 1760 esta província tinha de fato alguma relação com S. Salvador, uma vez que a classificação de reino não se dava apenas pela importância e extensão do território, mas pela pertença ao que chamou de império do Congo. No período de guerras civis na década de 1680 Mbula era ativa na disputa pelo poder em S. Salvador e a classificação de Savona indica que continuava a ser o caso no período pós-restauração. ${ }^{320}$

\section{$\underline{4.5 \text { Oando }}$}

Oando, assim como Mbula, foi apontado por Savona como um dos reinos do império do Congo. A pouca notícia que temos de Oando vem da pena de Savona, em apenas um parágrafo de seu texto:

O Reino de Oando é presentemente governado por uma rainha de se chama D. Violante Nani-Lemba Enlaza Castello Branco. São quase todos os seus súditos gentios, e se eles são batizados, são cheios de superstições, mas quase sempre choram para ter missionários. Quando passei batizei apenas nove mil e fiz um matrimonio. Neste Reino tivemos um hospício no Rio Dongo mas está arruinado há muitos anos e muitos desse povo comem carne humana, particularmente d'aqueles

\footnotetext{
${ }^{317}$ Heywood, Le Thornton, J. Central African Creoles and The Foundation of the Americas, p. 136-140.

318 Toso, Carlo. Relazioni inedite di P.Cherubino Cas sinis da Savona sul Regno del Congo e sue Missioni, p. 208 e Frei Rafael Castello de vide. Viagem e missão no Congo, p. 144-145.

319 Toso, Carlo. Relazioni inedite di P.Cherubino Cassinis da Savona sul Regno del Congo e sue Missioni, p. 207.

${ }^{320}$ Thornton, John K. Elite women in the kingdom of Kongo: Historical perspectives on women's political power, p. 456.
} 
que morreram em guerra. Estes são os que este ano queimaram a corte do Congo e saquearam a igreja e o Hospício. ${ }^{321}$

Apesar de curta, essa exposição da província pelo missionário nos traz elementos interessantes. Primeiramente, assim como Mucondo (ou o território mais amplo: terras da rainha) Oando era governado por uma mulher. Não sabemos infelizmente se a sucessão sempre se dava entre mulheres, como em Mucondo. Isso é provável, uma vez que D. Violande-Lemba Nlaza Castelo Branco, assim como a rainha Ana Afonso de Leão, carregava Nlaza em seu nome. No caso da rainha Ana, o "título" Nlaza era prerrogativa de mulheres que possuíam grande poder político e chefiavam makanda, o que poderia também (apesar de não possuirmos evidências) ser o caso de D. Violande. De todo modo, isso demonstra que Oando era um território dominado pelos quinlaza. Os mesmos quinlaza que em 1765 invadiram e saquearam S. Salvador, expulsando D. Pedro V e sua corte. ${ }^{322}$

Estas informações nos levam à hipótese de que Mucondo e Oando poderiam ser territórios politicamente aparentados na segunda metade do século XVIII, unidos pela tradição do poder político feminino advinda da fundadora dos quinlaza rainha Ana. Mesmo assim, Savona destaca o caráter bárbaro e gentil destes povos, o que aponta para uma distância considerável das mesmas práticas cristãs tão importantes para as elites de Mucondo.

É necessário apontar que esta descrição altamente negativa de Savona sobre povos de Oando se justifica, entre outras coisas, pelo amargor experimentado pelo padre diante da invasão e destruição de S. Salvador e expulsão do rei Pedro V e sua corte, com quem Savona cultivava boas relações. Mas a carga com que é descrito o "gentilismo" deste povo parece indicar sim para uma característica particular, sobretudo da

\footnotetext{
321321 Tradução livre: "Il Regno de Oando ancor esso retto da uma Regina, quale presentemente se chiama Donna Violandi Mani-Lemba Emlaza Castello Bianco, mà quasi il suoi suditti, sono Gentili, e se sono batisati, pieni de superstizioni, e idolatrie, ma pure sempre pangono por avere Missionari, ed io vi sono passato, ed avo battezato solamente da nove milla, e fatto uno solo matrimonio. Dentro de questo Regno avevamo l'Ospizio al fume Dongo, mà si e revinato de multi anni, e ancora di questi popoli mangiano carne umana, particolarmente quelli, che mojono in guerra, e questi sono, che anno abrucciato la Corte di Congo, e saccheggiato la Chiesa, e Ospizio.” Toso, Carlo. Relazioni inedite di P.Cherubino C. da Savona (...), p. 213.
}

${ }^{322}$ Toso, Carlo. Relazioni inedite di P.Cherubino Cassinis da Savona sul Regno del Congo e sue Missioni, p. 213. 
religiosidade popular. As altas elites de Oando certamente cultivavam algum nível de relação com o cristianismo, o que é evidente pela ligação de D. Violande com rainha Ana (que usava ela própria um hábito capuchinho). ${ }^{323}$ É provável que em Oando seja particularmente contrastantes as práticas religiosas populares e das elites.

\section{$\underline{\text { Soyo, Mossul e Ambuíla }}$}

Diferentemente das províncias citadas anteriormente (exceto Nsundi) Soyo, Mossul e Ambuila são consideradas províncias autônomas ou independentes. ${ }^{324} \mathrm{Na}$ verdade estes dois conceitos são bastante discutíveis, uma vez que, como debatemos no capítulo anterior, a questão da pertença ou não ao Congo para membros das elites políticas estava muito relacionada à esfera simbólica e identitária. Como discutimos anteriormente, alguns referenciais vinculados a tradição política congolesa eram os fatores determinantes para a unidade politica congolesa pós-restauração. Elementos simbólicos como a capital S. Salvador, os fundadores Lukeni e D. Afonso I e os elementos do catolicismo formavam as bases da identidade política congolesa no período. Além disso, o poder político e econômico do Mani Congo não se encontrava mais ancorado no controle direto (político, financeiro e militar) sobre as províncias como em períodos anteriores a 1650.

No século XVIII a fonte de poder (simbólico, político e financeiro) real encontrava-se relacionado ao controle de um aparato que remetia aos áureos períodos de centralização do poder e à identidade política congolesa, como vimos no capítulo anterior. Controlar a capital e gozar do título de ntotela oferecia ao Mani Congo, e a seu partido, o direito de cobrar tributos sobre o enterro de mortos nobres das províncias no terreno sagrado de S. Salvador e aos seus parentes. Isso dava ao rei o "controle" sobre o missionário, e em parte também sobre a atividade sacramental deste cobrando inclusive tributos dos nobres do interior que desejassem receber os sacramentos. Além disso, como vimos, a nomeação de cavaleiros de Cristo também era tarefa exclusiva do rei e de um padre, fonte importante de legitimidade e riqueza para os reis do período. Além

\footnotetext{
${ }^{323}$ Thornton, John K. Elite women in the kingdom of Kongo: Historical perspectives on women's political power, p.456.

${ }^{324}$ Broadhead, Susan H. Trade and Politics on the Congo coast, p.30-35.
} 
disso, havia a nomeação dos membros do Muana Congo com títulos de marques, duque, príncipe, entre outros, que deveria ser confirmada pelo rei, mesmo que previamente feita conforme as lógicas locais.

Por isso, se utilizados os critérios de períodos de intensa centralização do poder no Congo nos séculos XVI e XVII pode-se chegar à conclusão de que o Mani Congo não gozava de poder "de fato", pois sua legitimidade era mais simbólica. É evidente que esse tipo de separação entre poder prático e poder simbólico não pode ser estabelecida nas sociedades africanas (e talvez em qualquer outra sociedade). Nosso argumento consiste em apenas afirmar que em períodos anteriores a crise política, o Mani Congo possuía (além de sua importância simbólica) um poder mais direto sobre seus súditos e esse período formou uma tradição política muitíssimo forte, que possibilitou que o poder "simbólico" passasse a não mais depender de uma submissão direta. Desta maneira a relação de dependência não desapareceu, tampouco declinou, ela apenas tornou-se mais ligada aos fatores identitários e não mais dependentes (ao menos não completamente) da sujeição direta.

Essa legitimidade simbólica vinculada à tradição política do reino era de caráter absolutamente central nos jogos de poder, tanto em S. Salvador, quanto nas províncias. Por isso, devemos deixar de lado o viés do período de centralização de poder e compreender que no Congo restaurado o poder "simbólico" tornara-se um poder "de fato". E o poder "de fato" tornou-se essencialmente simbólico.

Nesse sentido, é complexo determinar a completa autonomia ou independência de províncias tradicionais como Soyo (principalmente), Nsundi, Ambuíla e Mossul. O critério que estabelecemos como raiz para a diferença na relação destas províncias com S. Salvador é o fato de não participarem diretamente (apresentando candidatos) das eleições de rei do Congo. Isso não significa, absolutamente, que estas não poderiam intervir, apoiar ou repudiar um ou outro grupo que estivesse no poder, como veremos.

Do ponto de vista da tradição política do reino do Congo desde a sua fundação, pode-se dizer que o território de Soyo foi a mais importante e poderosa dentre as províncias. Além de vastíssima encontrava-se muito bem localizada, ao noroeste do Congo. Fazia margem ao norte com o caudaloso rio Zaire, que acompanhava até a sua foz no oceano atlântico (no porto de Mpinda), sua fronteira a oeste. Ou seja, era entreposto essencial entre S. Salvador e o mar ou o rio Zaire. ${ }^{325}$

\footnotetext{
${ }^{325}$ Heywood, L e Thornton J. Central African Creoles and the Foundation of the Americas, p. 138-143.
} 
Além da privilegiada posição geográfica, o Mani Soyo gozava tradicionalmente de privilegiada posição política diante do Mani Congo. Os chefes de Soyo exerceram sempre participação ativa e determinante na política congolesa. Lembremos do já citado exemplo da chegada dos primeiros portugueses ao litoral do Congo na década de 1480, ocasião na qual o soberano de Soyo foi o único a obter licença para receber o batismo antes do rei Nzinga a Nkuwu, sendo ele próprio o responsável por permitir que os portugueses chegassem até a corte congolesa de Mbanza Congo. Assim como os momentos de boas relações entre o Congo e Soyo fortaleciam o poder real, em períodos turbulentos, as desavenças com a capital geraram grandes crises políticas. ${ }^{326}$ Vale lembrar que a crise em meados do século XVII que culminaria na desastrosa guerra de Ambuila teve início com a emancipação da província, que rompeu os laços de dependência militar com o Congo. Esse evento, segundo Thornton, teve importância imensa na derrota do Congo frente ao exercito português em Ambuíla em 1665, assim como em período posterior foi o apoio militar de Soyo que permitiu a expulsão dos portugueses vitoriosos. Além disso, mesmo independente, o apoio de Soyo ao rei Pedro IV Nessama a Mbandu foi vital para que este conseguisse retomar a capital S. Salvador e restaurar o Congo em 1709. ${ }^{327}$

Observando a centralidade da influência de Soyo para o reino do Congo, mesmo após sua formal independência, e a complexidade desta relação de dependência, tornase uma tarefa espinhosa determinar o tipo de relação política e o grau de influência que esta província exercia na segunda metade do século XVIII. Além do que, possuímos pouquíssimas pistas na documentação, uma vez que nosso principal informante frei Rafael não missionou na região. Esta ausência, por si só, é um fato que gera questionamentos. Savona, por sua vez, foi à Soyo em 1760 e muito se impressionou com a "cristandade" de sua população e as inúmeras igrejas de sua corte.

Analisemos, por etapas, a descrição de Savona:

A província de Soyo é ainda grandíssima, de muita extensão e tem fronteira com o Zaire, e realmente tem ilhas povoadas nesse grande Rio, cheias de palmeiras, todas de sua jurisdição . São quase todos cristãos e a maior parte fugidos de guerra da outra parte de Loango,

\footnotetext{
${ }^{326}$ Hilton, Anne. Kingdom of Kongo, p. 50-56.

327 Thornton, John: The Kongolese Saint Anthony. Dona Beatriz Kimpa Vita and the Anthonian moviment, p. 28-31.
} 
são gente espirituosa e capaz. Do outro lado tem fronteira com o mar. Esta província é governada por um príncipe, que tem maior corte que o próprio rei do Congo, e se chama D. Miguel de Castro e Sylva, casado, bom cristão, lê e escreve em língua portuguesa e seu povo e muito afetuoso com os missionários e amantes dos sacramentos. Em todo seu marquesado, cidades e terras há mais de meio milhão de almas. No ano de 1760 fui àquela província e encontrei hospício e igreja, que tem nomes de S. Salvador e Sto Antonio. Se destruiu e depois reergueu igreja e hospício, e para isso contribuiu o príncipe e todos os vassalos. Esta província tinha inúmeras igrejas que hoje se conservam apenas os lugares e suas cruzes. E é costume fazerem procissões nos dias de santo aos quais eram dedicadas. ${ }^{328}$

O poder político em Soyo continuava sendo ritualizado por elementos cristãos, e assim parece ter sido desde o primeiro batismo do Mani Soyo no século XV. Talvez no caso de Soyo a relação do cristianismo com o poder político tenha sido particular em relação às outras províncias. Argumentamos que de maneira geral os elementos do cristianismo remetiam (no período pós-unificação) a uma refundação mítica por D. Afonso I Mvemba a Nzinga e posteriormente dos demais reis cristãos. Por isso, a ancestralidade de Mvemba a Nzinga tornara-se um elemento central para a legitimidade política das elites dirigentes (Muana Congo). No caso de Soyo, parece haver, além desta pertença ao Congo, uma tradição política local fortíssima também ligada ao cristianismo. Portanto, talvez ocorressem paralelamente, e obviamente relacionadas, duas identidades ritualizadas pela via do cristianismo: a local e a central, o que permitiu a Soyo tornar-se formalmente independente de S. Salvador e continuar a reproduzir localmente a ritualização do poder central. Isso aparece quando notamos a descrição de

\footnotetext{
328 Tradução livre: "La Provincia di Sogno, ancor ella grandissima, e di molti e di molta estasione, e confina col Zaire, anzi a molte Insole in quel gran Fiume populate, e piene di palme, tutte di sue giurisdizione, e sono quase totti Cristiani, (...) gente spirituosae capace, e dall'altra parte confina com mare. E governa questa província da um Principe, che tiene la Corte com piu grandezza, che il Medesimo Rè di Congo, e si chiama presentemente D. Miguel de Castro da Sylva, uomo mariato, e bono Cristiano, e sà legere, e serivere in língua portughese, e li suoi popoli sono bene affeti a Missionari, e amanti de Sagramenti, e farà tra suoi Marchesati, Città. e Terre, più de meglio millione d'anime, e nell'anno 1760 io fui in quella Privincia e trovai l'Ospizio, e Chiesa, che hà titolare S. Salvatore e S. Antonio. Afatto distrutti, e di nuovo fabricai Chiesa e Ospizio e vi concorse il Principe com tutti il suoi Vassali. Erro ancora em questa Provincia di Sogno anticamente molti Chiesi de quali ora si conversano solamente politi e Loughi com le sue Croci, e sempre si venerano e medemi, e costumano farvi le processioni ne giorni de suoi Santi, a quali era dedicate." Toso, Carlo. Relazioni inedite di P.Cherubino Cassinis da Savona sul Regno del Congo e sue Missioni, p. 209.
} 
Savona acima que diz que " tinha inúmeras igrejas que hoje se conservam apenas os lugares e suas cruzes. E é costume fazerem procissões nos dias de santo aos quais eram dedicadas." ${ }^{329}$ Cenário muito semelhante ao da corte.

Pode-se afirmar que este mesmo cenário podia também ser visto em Quibango, por exemplo, que possuía diversas igrejas e uma forte tradição de contatos com os elementos cristão. Porém em Quibango enxergava-se, em ultima instância, S. Salvador como referencial político maior, uma vez que continuavam a disputar o cargo de rei e mesmo em períodos de hegemonia quinlaza continuavam a exercer papel de oposição, como observamos no capítulo segundo. Além disso, o discurso da tradição deste monte sempre remetia aos grandes Mani Congos ancestrais. Mbanza Soyo, por sua vez, parece ter tido no século XVIII - e talvez em períodos anteriores - uma autonomia simbólica em relação ao Congo. Desta forma, sua elite pode recorrer ao argumento da relação com o Congo como elemento legitimador, mas este não parece ter constituído a espinha dorsal da legitimidade política, como ocorreu em outras regiões.

Assim com o S. Salvador, Mbanza Soyo conservou o local das antigas igrejas (mesmo que no período estivessem em ruínas). Na descrição de Dicomano, as igrejas de S. Salvador eram algo; "que agora só se podem chamar cemitérios" ${ }^{330}$, pois teriam se tornado local privilegiado de culto aos mortos, aos quais os membros das elites políticas dirigiam procissões e onde faziam oferendas, enquanto rezavam o rosário. ${ }^{331} \mathrm{Em}$ Soyo, pela descrição de Savona, as igrejas eram lembradas não pelos mortos ali enterrados (talvez tenha ignorado ou não notado esta intersecção de cultos), mas pelos dias dos santos padroeiros de cada igreja. Savona chega a listar as onze antigas igrejas da capital de Soyo especificando qual seria o santo correspondente a cada uma, o que demonstra que seus informantes (infantes ou mestres) tinham esta informação como relevante, mesmo que nesses locais só se encontrassem terreiros com cruzes. ${ }^{332}$

Lembremos da já citada hipótese de Anne Hilton, na qual grandes nobres, principalmente reis, teriam construído em vida igrejas vinculadas a santos padroeiros para que nelas fossem enterrados e estes teriam se tornado locais de culto aos

\footnotetext{
${ }^{329}$ Toso, Carlo. Relazioni inedite di P.Cherubino Cassinis da Savona sul Regno del Congo e sue Missioni. 209.

330 Correa, Arlindo. Informação o reino do Congo por Raimundo Dicomano (...), p.1-2.

${ }^{331}$ Frei Rafael Castello de vide. Viagem e missão no Congo, p. 167-168.

${ }^{332}$ Frei Rafael Castello de vide. Viagem e missão no Congo, p. 145-149.
} 
antepassados, sendo a ancestralidade fonte de legitimidade política. ${ }^{333}$ Se para $\mathrm{S}$. Salvador consideramos esta tese discutível no período, no caso de Soyo ela parece fazer sentido.

Outro elemento que indica uma autonomia da tradição "católica" em Soyo em relação ao restante do reino é a questão da divisão dos missionários entre Mbanza Soyo e S. Salvador. No texto de Frei Rafael fica evidente que o governador e bispo de Angola pretendiam enviar um grupo de missionários ao Congo e outro para Soyo. ${ }^{334}$ Por algum motivo não explícito pelo padre ocorre desistência em enviar missionários para Soyo, mas é interessante notar que nos quase dez anos de missão de Castelo de Vide e Godinho não há menção à viagem para Soyo, o que indica que os papeis dos missionários residentes em S. Salvador e os de Soyo não se misturavam.

$\mathrm{Na}$ carta, da qual tratamos anteriormente, enviada em 1785 pelo bispo de Angola Alexandre da Sagrada Família a Martinho de Mello e Castro, são citadas informações de padres capuchinhos, missionários em Soyo. Ou seja, enquanto Frei Rafael e Pe. Godinho encontravam-se sob a "tutela" do Mani Congo, havia missionários específicos vinculados ao Mani Soyo. ${ }^{335}$ Infelizmente não temos notícias sobre os textos escritos por estes padres, desta forma não se pode traçar um paralelo entre o tipo de relação dos padres com o soberano de Soyo e o rei do Congo.

Argumentamos que Soyo gozava de uma autonomia político-religiosa do Mani Congo muito evidente no período pós-restauração do poder central no Congo. Nada disso quer dizer, porém, que não havia relações e influência política em ambas as direções. O Mani Soyo parece continuar a exercer influência política em S. Salvador. Em momentos de impasse e disputas envolvendo o poder central, Soyo parece entrar em cena mediando conflitos ou mesmo apoiando um dos lados envolvidos. Vale lembrar o impasse entre os missionários (Frei Rafael e Pe. André Godinho) e o rei Antônio II sobre os mobires (vilis) que atuavam como traficantes na corte e sua mediação. Após o já citado conflito de Frei Rafael com Bua Lau, nobre congolês que financiava a ação dos vilis, os padres decidiram fechar a igreja e interromper toda e qualquer atividade sacramental até que o rei tomasse controle da situação em favor dos padres. ${ }^{336}$ Neste

\footnotetext{
${ }^{333}$ Hilton, Anne.The Kingdom of Kongo, p. 87-93.

${ }^{334}$ Frei Rafael Castello de vide. Viagem e missão no Congo, p. 23.

${ }^{335}$ Arquivo Histórico Ultramarino, AHU, papéis de angola, cx 70, doc 28.

${ }^{336}$ Frei Rafael Castello de vide. Viagem e missão no Congo, p. 291-293.
} 
contexto, membros da elite de Soyo aparecem como importantes interventores, enviando cartas ao padre e ao rei que (segundo Frei Rafael) desaprovava as decisões reais:

Este procedimento do Infante estranharam muito os Príncipes de Sonho criticando o novo Reinado, principalmente um dos Grandes, que pretendeu o Reino, no tempo da vacancia, nos mandou dar satisfação, e pedir-nos que não os desamparássemos por isso, nem deixássemos os serviços de Deus, pelo que sofríamos nestes tempos, e tivéssemos paciência. ${ }^{337}$

Além da evidente importância da intervenção dos príncipes de Soyo, notamos que o principal deles "um dos Grandes", em algum "período de vacância" do poder "pretendeu o Reino". Ora, parece-nos evidente aqui uma postura muito ativa de Soyo com relação ao poder central do Congo, muito mais ativa do que se esperaria de uma província independente. Se o dito príncipe pretendeu ocupar o poder (em tempo de vacância) percebemos uma postura de Soyo com árbitro do poder. Não sabemos exatamente de qual período "de vacância" se trata. Duas hipóteses prováveis seriam entre os reinados de Alvaro XI Nebica a Sunga e D. José I Nepaxi a Giacana, período no qual os quimpanzo ocuparam a capital (uma vez que Soyo tradicionalmente apoiava os quimpanzo).$^{338}$ Ou neste mesmo período entre a morte de Afonso V Necanga a Canga e a ascensão de Antônio II Nevita a Mpanzo, transição que instaurou a crise descrita por Frei Rafael. Parece-nos ter sido o primeiro caso, pois a segunda transição ocorreu mais rapidamente.

De qualquer forma, vemos aqui a atuação determinante das elites políticas de Soyo, que chegaram a pretender ocupar a regência do Congo em períodos de impasse e tornavam-se importantes mediadoras dos conflitos em S. Salvador. Pelos motivos expostos notamos a grande complexidade da relação de pertença de Soyo ao Congo, algo que não pode ser traduzido completamente por termos como "independente" ou "autônomo". O tipo de dependência de Soyo com relação ao Congo, e vice-versa, foi no período pós-unificação de natureza diferente da de períodos anteriores. De qualquer

\footnotetext{
${ }^{337}$ Frei Rafael Castello de vide. Viagem e missão no Congo, p. 295.

338 Thornton, John: The Kongolese Saint Anthony. Dona Beatriz Kimpa Vita and the Anthonian moviment, p. 28-31.
} 
maneira podemos considerar Soyo não apenas como parte do Congo no período mas como integrante bastante importante.

Com fronteiras delimitadas entre o rio Loge (norte) e Dande (sul) se encontravam as províncias de Mossul e Ambuila. Mossul a oeste (fazendo fronteira com o mar) e Ambuíla a leste. São ambas bastante extensas e marcam a fronteira sul do reino do Congo. Devido à posição privilegiada para o comercio de escravos e a proximidade da colônia lusa de Luanda, esta região foi historicamente marcada por constantes conflitos com portugueses e acirradas disputas pelo controle das rotas e dos portos no litoral. A respeito destas províncias, encontramos dificuldades semelhantes à Soyo na determinação da relação política com o Congo. Vejamos cada um dos casos.

Em todas as fontes às quais temos acesso, o relatório de Savona é o único que trata especificamente de Ambuila no aspecto de seu pertencimento ao Congo: "Esse estado é grandiosíssimo e teria mais de quinhentos mil habitantes [número inverossímil], mas poucos reconhecem o rei do Congo e se fazem absolutos". ${ }^{339}$ Apesar de sucinta, essa afirmação é bastante significativa frente aos casos de outras províncias. São raros os exemplos, em toda a documentação, de localidades tradicionalmente pertencentes ao reino do Congo que se afirmam independentes. $\mathrm{Na}$ verdade, esta independência é antes fruto de um olhar para a geografia política congolesa com base numa dependência muito direta (pagamento de tributos e composição militar). $\mathrm{O}$ fato dos nobres de Ambuíla se afirmarem absolutos demonstra que este pode ser um dos casos em que a desvinculação simbólica e identitária no campo política tenha ocorrido no período de guerras civis. Em períodos anteriores a batalha de 1665 Ambuila firmou contratos de vassalagem com Portugal, mas os descumpriu, motivo que justificou a invasão militar.

Destacamos no segundo capítulo a importância do interior de Ambuíla para rotas em direção ao sul rumo ao porto de Luanda e a grande circulação de afro-portugueses e ambundos a serviço da coroa portuguesa. Situação absolutamente diferente de regiões que de fato integravam o território congolês, nas quais a circulação de luandenses era ínfima. Ao tratar desta rota comercial Dicomano apresenta Ambuila como um dos

\footnotetext{
339 Toso, Carlo. Relazioni inedite di P.Cherubino Cassinis da Savona sul Regno del Congo e sue Missioni, p. 210-211.
} 
"sítios da Conquista de Portugal" 340 no qual haveria comunicação entre alguns congoleses mercadores de escravos (como os de Quibango) e os lançados afroportugueses para venderem aos navios brasílicos e lusos no porto de Luanda. Esta era interação pouco comum no período pós-restauração (pois a hegemonia comercial se dava pelos vilis que vendiam a outras nações europeias nos portos do norte) e parecia ter Ambuîla como palco privilegiado. Portanto, esta constituía um dos poucos territórios de transição onde ocorria livre circulação de congoleses, ambundos, luso-africanos e portugueses. Essa abertura teve provável origem na batalha ocorrida nesta província em 1665, que marcou o início do período de desorganização política congolesa e da permanente inimizade entre Congo e Portugal. Em relação aos regentes de Ambuíla, notamos uma constante ambiguidade ao afirmarem-se ora pertencentes ao Congo, ora parceiros de Luanda, o que talvez tenha sido estratégico para a manutenção de sua autonomia em relação a ambos.

Este não era o caso do território vizinho de Mossul. Esta província foi bastante particular e interessante, sobretudo por ser comercial e territorialmente estratégica, sobretudo para o império português. A ambição pelo controle do trafico de escravos na região portuária de Mossul, que tinha na foz do rio Loge (sua fronteira norte) um importante entreposto de escravos, somado à massiva presença de ingleses e franceses na área fez desse território palco de diversos conflitos que envolviam interesses de diferentes nações europeias e interesses locais. ${ }^{341}$ No capítulo primeiro nos focamos nas questões comerciais e na empreitada militar portuguesa nas décadas de 1770 e 80 com o objetivo de dominar o trafico de escravos na região. Vimos que os lusitanos esbarraram em interesses locais e na vontade de ingleses e franceses que tinham se tornado no período os parceiros privilegiados dos congoleses desta região. Nosso foco neste capítulo é a questão política e a relação, não com Luanda mas, com S. Salvador, sobre a qual temos poucas informações. Porém, dispomos de algumas pistas, um tanto fragmentárias.

Suzan Broadhead, por ter trabalhado sobretudo com fontes relativas ao trafico de escravos, definiu o marquês de Mossul (no século XVIII) como "um antigo vassalo do reino do Congo". Essa perspectiva faz sentido dentro da abordagem da historiadora,

\footnotetext{
${ }^{340}$ Correa, Arlindo. Informação o reino do Congo por Raimundo Dicomano (...), p. 11.

${ }^{341}$ Broadhead, Susan H. Trade and Politics on the Congo coast, p.51.
} 
uma vez que em temas relativos ao comércio costeiro de escravos as elites de Mossul pareciam, de fato, gozar de absoluta independência, por isso Broadhead definiu-o como um dos "broker states" da costa congolesa. ${ }^{342}$

Frei Rafael de Vide, em sua primeira passagem por Mossul em 1780, quando viajava (com toda a comitiva) para o norte em direção a S. Salvador afirmou:

(...) saímos de Luanda ou S. Paulo da Assunção, como se intitula a capital de Angola, no dia 2 de Agosto de 1780, e deixando as comodidades com que nos enviaram os Ex.mos Snrs. do Governo espiritual e temporal, falemos dos trabalhos que logo principiámos a padecer, que não foi tanto em terras que ainda são do domínio de Nossa Soberana, e em o Marquesado de Mossul, e do Bumba, que já pertence ao Rei do Congo. ${ }^{343}$

Frei Rafael, nas três ocasiões que descreveu sua passagem por Mossul indo a Luanda (ou voltando ao Congo) apresentou-a como a primeira província do Congo. Além disso, fica claro em sua descrição que a jurisdição da rainha de Portugal terminava ali, ao cruzar o rio Dande em direção ao norte. Quando passou por Mossul em julho de 1785 com a embaixada enviada pelo governador de Angola ao Congo, chefiada por um tenente de infantaria para tentar negociar com o então rei D. Afonso V, frei Rafael descreveu a tensão vivida entre a gente a província e os portugueses:

(...) no dia seguinte aportámos no Dande, aonde achámos tudo pronto com gente e refrescos por ordem do Senhor General para nos transportarem até o Libongo, última terra da nossa jurisdição; e ali se veio ajuntar o Militar com os seus soldados, e o seu negócio para entrarmos todos por terra adentro, e já ali nos esperava o Embaixador do Congo, que se havia adiantado, e no dia 24, passámos ao Indui, e daí ao Itabe, primeira terra do Mossul, Marquesado do Congo: não falo do bem que fomos recebidos, e os brancos, ainda que para eles é

\footnotetext{
${ }^{342}$ Broadhead, Susan H. Trade and Politics on the Congo coast, p.53-60.

${ }^{343}$ Frei Rafael Castello de vide. Viagem e missão no Congo, p. 310-311.
} 
gente nova nestes caminhos mas pelo respeito de Luanda, que como vizinhos temem, e pela reverência dos Padres, e por saberem que o militar, que era um Tenente de Infantaria vinha como Embaixador para o seu Rei, nos fizeram muitos presentes, e o mesmo Marquês veio da sua Banza a visitar-nos, por ver também assim se obtinha a graça do Ex.mo Senhor General, cujo enfado tinham experimentado, e ainda os tinha privado de entrarem em Luanda, o que eles muito $\operatorname{sentiam}(\ldots)^{344}$

Aqui, Castelo de Vide, nos apresenta um cenário de rivalidades e conflitos entre os habitantes de Mossul e os portugueses, devido aos recentes confrontos nos quais os militares lusitanos tentaram bloquear a ação francesa e inglesa nesta província, principalmente no porto de Ambriz. Como expusemos no capítulo primeiro, os portugueses não possuíam condições militares, tampouco diplomáticas de se fixarem nesta região, principalmente pela forte aliança que gozavam os nobres locais (e o Mani Congo) com ingleses, holandeses e franceses, que barravam os portugueses agindo na diplomacia do contexto europeu. Mesmo tendo os atores locais de Mossul como determinantes, acreditamos que o importante vínculo simbólico e territorial destes com o Congo também foi fator determinante para a manutenção de sua soberania (até a invasão definitiva de Portugal em 1855). ${ }^{345}$

Outra destas campanhas portuguesas a Mossul ocorreu entre 1791 e 92 e foi citada (através de Broadhead) no primeiro capítulo. Paulo Martins Pinheiro de Lacerda, coronel de infantaria do exército da Coroa portuguesa, chefiou tal operação e descreveua em relatório posteriormente publicado pela associação marítima e colonial no contexto de ocupação em meados do século XIX. ${ }^{346}$ Nesta fonte, Lacerda relata sua empreitada militar e vitória sobre os exércitos de Mossul e posteriormente seu fracasso devido a intervenção da corte inglesa, que fez com que a soberana portuguesa ordenasse a retirada de seus exércitos da região. Estes fatos foram relatados no capítulo mais focado

\footnotetext{
${ }^{344}$ Frei Rafael Castello de vide. Viagem e missão no Congo, p. 241, 242.

${ }^{345}$ Sobre o contexto de Mossul no século XIX: Wissenbach . Entre caravanas de marfim (...). 2008.

346 Lacerda, P. M. P. Notícia da Companha e Paiz de Mosul, que conquistou o sargento mor Paulo Martins de Pinheiro Lacerda, no anno de 1790, até o princípio de 1791. Annaes da Associação Marítima e Colonial, sexta série. Lisboa. Imprensa nacional. 1846, p.127-133. Agradeço imensamente ao prof. Thornton pela concessão da cópia digitalizada deste documento.
} 
em temas comerciais, e foi bastante trabalhado por Broadhead. Para nossos objetivos aqui, o texto de Lacerda é também bastante útil:

Nesta Província do Mossul há as povoações seguintes, sendo a maior delas a do Marques, que fica no centro e é grande, a do souso que fica no centro e é quase o mesmo, e seu chefe se apelida General, ao qual fiz prisioneiro na batalha e se chamava D. Miguel (...).

Adiante: Como por aquelas províncias tem entrado missionários Barbadinhos, eles cuidam muito em que se batizem seus filhos, e presumem de serem católicos romanos trazendo ao pescoço crucifixos de metal, como os mesmos missionários, e alguns até cirzinhos e coroas e também barbas compridas, porém não se entende a mais sua religião do que estes exteriores, e no mais conservam sua barbaridade $(\ldots)^{347}$

Vemos aqui descritas características que aproximam muito os mossuis do Congo. $\mathrm{O}$ uso do título de marquês e do nome português como forma de legitimidade, além da auto identificação como cristãos e o uso de insígnias e mesmo barba à moda capuchinha. Além da questão religiosa, Lacerda debate também a identidade política, não apenas na região de Mossul, mas no Congo como um todo:

Enquanto aos costumes, em nada diferenciam do Mossuis, por serem todos de classe dos Congos, e Muxicongos, a cujo Monarca eram todos sujeitos em tempos antigos, e ainda hoje se prezam serem vassalos daquele rei, mas na verdade está todo aquele reino dilacerado, porque o Mosul, se chama Marquês do Rei do Congo. O do Onde, se chama Conde; o de Quina se chama Duque, este já se apelida Rei, o de Mpemba se chama Duque; mas nenhum deles obedece ao Rei e são cada um senhores despóticos nos seus Estados;

${ }^{347}$ Lacerda, P. M. P. Notícia da Companha e Paiz de Mosul, (...), p. 127-133. 
mas quando os apertam, todos protestam com a vassalagem e sujeição do Congo $(\ldots)^{348}$.

As apreciações de Lacerda quanto à identidade política (e religiosa) congolesa através das elites das províncias do Congo são muito interessantes. Sua absoluta incapacidade de compreender a complexidade da conformação da identidade congolesa é patente. Através de seu olhar europeu, Lacerda aponta para duas contradições. Primeiramente, o fato dos congoleses de Mossul se comportarem como católicos (utilizando insígnias e imitando comportamentos dos próprios capuchinhos) e ao mesmo tempo preservarem aquilo que chama de "barbaridade", ou seja, sua especificidade nos rituais e costumes. A segunda contradição se deve ao fato de exaltarem a sua vassalagem ao rei do Congo e ao mesmo tempo "não obedecem ao rei e são todos senhores despóticos em seus Estados".

Ora, esses dois elementos: o "ser católico" e o "ser sujeito ao rei do Congo"; apresentados, são os vetores da identidade política congolesa no período. As pesadas críticas do militar português se deram porque, a partir de sua perspectiva ocidental, ambas as pertenças: política ao Congo e religiosa ao cristianismo não se davam como ele conhecia tradicionalmente. Para ele (como agente colonialista) a sujeição política deveria ser construída por mecanismos de dependência econômica e submissão militar. Como cristão português, a conversão ao catolicismo deveria ocorrer como um fenômeno absoluto e não poderia conviver com praticas religiosas tidas como pagãs ou heréticas. Naturalmente, ele não compreendeu os sentidos específicos que o "pertencer a um reino" e "ser praticante de sacramentos e portar insígnias católicas" possuíam no Congo.

Deixou também de perceber que ambas: a sujeição ao Mani Congo e o uso cotidiano de elementos do catolicismo encontravam-se interligadas num sistema político que transcendia o recolhimento de tributos ou a sujeição militar. Estes diziam respeito a um pertencimento profundo e mítico cotidianamente ritualizado pela memória do Mani Congo D. Afonso I (ao qual toda a muana Congo estaria ancestralmente vinculada); pela nomeação de marqueses, duques ou príncipes; pelo enterro dos mortos em S. Salvador nas ruinas das igrejas vinculadas a cada ancestralidade; pela nomeação dos cavaleiros da ordem de cristo; pelo trabalho ritualístico dos padres europeus; dentre outros.

\footnotetext{
${ }^{348}$ Lacerda, P. M. P. Notícia da Companha e Paiz de Mosul, (...), p. 127-133.
} 
Além do mais, é evidente que reivindicar o pertencimento ao Congo (sobretudo para as províncias ao sul) era uma ferramenta de defesa contra invasões lusas. Pois como vimos no segundo capítulo, a parceria comercial entre holandeses, ingleses e franceses e o Congo (principalmente o norte) garantiam proteção no plano internacional.

Por isso, um trabalho de história congolesa não pode reproduzir os binômios trazidos pelas fontes europeias: dependente/ independente, católico/não-católico, vassalo/não-vassalo, centralizado/fragmentado. A especificidade da história política congolesa vai além dessas rotulações dualistas. Desta forma, notamos que o reino do Congo após sua reunificação, permaneceu com suas principais províncias a ele vinculadas, em um pertencimento de outra natureza, na qual os elementos do catolicismo (em maior e menor grau) funcionavam como elementos de rememoração desta identidade.

Observaremos, adiante, através da documentação, os principais elementos utilizados para a ritualização desta rememoração, que conferia grande legitimidade às elites locais.

\subsection{O sacramento do matrimónio e as elites locais}

O estudo sobre o casamento cristão no Congo do século XVIII esbarra em desafios semelhantes aos que temos enfrentado ao longo desta pesquisa. Nossos informantes, presos a uma visão do casamento cristão europeu, não puderam compreender a especificidade que este ritual possuía para as elites congolesas. Assim como sobre outras práticas cristãs, a visão dos missionários sobre o matrimônio no Congo é apresentada como uma reprodução dos sentidos originais católicos, uma vitória da catequese. Ou mesmo apresentado como uma deturpação do sentido "original", uma vez que a prática sacramental do matrimônio, em geral, convivia com a prática social da poligamia.

Esse embate entre o que os padres consideravam como verdadeiro matrimónio cristão e as práticas polígamas estão muito presentes nos relatos. Esta foi uma questão central nos relatórios de missão e uma contradição no trabalho catequético cotidiano. Pode-se afirmar que a questão da poligamia constituiu-se como o maior obstáculo cotidiano enfrentado pelos padres nas missões. 
Como se sabe, o foco da presente pesquisa não é a história da missão católica europeia no Congo, tampouco a missionação. Se fosse este o caso, abordaríamos com mais profundidade os embates da missão em si. O objetivo que buscamos é acessar as especificidade da relação dos congoleses com o catolicismo, e não o inverso. Por isso, nos debruçaremos sobre a importância deste ritual (muito maior do que a instituição social do casamento) como elemento de rememoração de uma identidade política congolesa e de legitimidade política para elites congolesas. Ao passar pelo ritual do casamento, os homens e mulheres das elites congolesas ganhavam um status social diferenciado e esta prática não parecia contradizer os modos tradicionais do casamento poligâmico, exceto quando a realização do mesmo esbarrava na recusa do padre e na exigência do abandono das práticas tradicionais. Devemos tratar primeiramente do papel social do casamento no Congo, para em seguida debater o sacramento católico neste contexto.

O casamento poligâmico era elemento essencial para a organização social, política e econômica no Congo, que operava num sistema matrilinear e matrilocal. $O$ papel econômico da mulher congolesa era importantíssimo, pois em geral, eram as responsáveis pelo plantio e pela colheita de alimentos. Aos homens eram delegados trabalhos mais pesados: caça, construção e limpeza dos campos para o plantio. Por isso, a riqueza e capacidade de produção de uma família se baseava no número de mulheres para lavrar as terras. Além disso, o número de mulheres era um elemento central de legitimidade social. Cada casamento significava uma nova aliança entre famílias. Quanto mais esposas possuía um nobre, mais familias aliadas e mais poder político e econômico. ${ }^{349}$

O dote era dado pelo homem à familia da mulher. Portanto quanto mais riqueza, maior o número de alianças poderiam ser estabelecidas pelos homens; no caso da família das mulheres, estabeleciam-se alianças e ganhava-se por isso. Apesar de vantajoso para a família da então noiva, a ausência de filhas poderia criar esvaziamento da força produtiva, o que fazia com que ocorresse constante incorporação de novas mulheres às familias gerando novas alianças. ${ }^{350}$ Vejamos a rica (e bastante crítica) descrição de Dicomano sobre esse sistema:

\footnotetext{
349 Correa, Arlindo. Informação o reino do Congo por Raimundo Dicomano (...), p. 4.

350 Correa, Arlindo. Informação o reino do Congo por Raimundo Dicomano (...), p. 3-5.
} 
Porque um homem, que tem apenas uma mulher é sempre pobre, não tem que comer e não é estimado, porque entre eles existe o costume de que só as mulheres trabalham, e têm de dar de comer aos homens; ora como pode uma mulher trabalhar tanto que dê para comer o marido, ela e os filhos? Mas se um homem se casa com dez, vinte e trinta, ou mais mulheres (eu conheci alguns que tinham até oitenta), então este fica rico e grande senhor, porque estas mulheres dividem o ano entre elas, e cada uma dá de comer ao marido no tempo que lhe cabe, e o marido é obrigado naquele tempo a dormir com a mulher que lhe dá de comer, por isso todas procuram tratar bem o seu marido e este vive bem. $^{351}$

O sistema rotativo entre as muitas mulheres de um mesmo marido e a pluralidade de esposas permitia que houvesse maior autonomia destas (em relação aos maridos); pois cada uma delas era responsável apenas por sua casa e seus filhos (que em geral não eram muitos). As obrigações em relação ao marido existiam apenas no tempo de estadia do mesmo em cada casa. Este sistema, ao mesmo tempo, permitia aos homens gozarem também de autonomia: uma vez que eram diretamente responsáveis pelo sustento de todas as mulheres e filhos, podiam estabelecer numerosas alianças, desde que dispusessem do dinheiro do dote.

O pai possuía a autonomia para a circulação entre diversas casas de diferentes esposas pois era um membro secundário na organização familiar. No sistema matrilinear e matrilocal, a transmissão da linhagem e ancestralidade de um homem se dava através das mulheres de sua familia (suas irmãs) e não de suas esposas. Ou seja, os herdeiros de um homem eram seus sobrinhos, filhos de sua(s) irmã(s), ou seja, filhos das mulheres de sua familia. A transmissão de herança, por exemplo, se dava de pai para filho apenas na ausência de sobrinhos nascidos de irmãs. ${ }^{352}$

O fato do pai biológico não ocupar centralidade no eixo familiar permitia grande fluidez ao sistema de alianças entre familias, sendo possível uma pluralidade enorme de casamentos (ao menos nas elites) e mesmo a dissolução dos mesmos e devolução dos

\footnotetext{
351 Correa, Arlindo. Informação o reino do Congo por Raimundo Dicomano (...), p. 4-5.

352 Correa, Arlindo. Informação o reino do Congo por Raimundo Dicomano (...), p. 4.
} 
dotes (que desfazia a aliança entre as famílias), e permitia novos casamentos e novas alianças. Dicomano nos informa que, em caso de morte de um marido, o sobrinho (ou sobrinhos) deveria assumir o papel do tio diante das esposas, se tornando o novo marido, o que não afetaria significativamente a organização familiar, uma vez que a herança se dava através da mulher, independente do pai.

As mulheres da família de um homem, pelas quais a transmissão familiar se dava, eram sempre as suas irmãs. Os seus "filhos" (para fins de herança) eram os filhos destas irmãs. Desta forma, o eixo marido-mulher não era fundamental na organização e transmissão familiar como na Europa, e sim o eixo irmão-irmã. Por este motivo, a instituição do casamento como elemento de sacralização e fixação de um casal monogâmico como eixo central da família era absolutamente inaplicável à realidade social congolesa.

Mesmo assim, a prática ritual do matrimônio era constante no período, assim como fora em períodos anteriores. Cabe-nos buscar compreender a especificidade deste ritual e os sentidos que ganha no contexto congolês. ${ }^{353}$ Sobre isto, Frei Rafael nos oferece pistas relevantes, ao relatar o costume comum dos padres além de ministros tornam-se também padrinhos ou compadres:

Isto de serem compadres dos Padres, e afilhados é para esta gente ou grande honra, ou devoção; por isso, nesta Missão, e nas outras, e ainda na Corte mesmo, muitos me vêm rogar para isso; e eu sempre os satisfaço, e sei o modo, que posso para isso, e para eles não desconfiarem ou perderem a sua devoção, é ponto que eles têm de honra. Nos casamentos dos maiores Fidalgos, Infantes e Príncipes, sempre o Padre há-de ser o seu Padrinho, porque, dizem eles, que não têm outra pessoa maior, mas eu sempre procuro que hajam as testemunhas do Concílio nos casamentos, e no baptizado os legítimos padrinhos, e eles sempre ficam com o título de Compadres, ou afilhados, e se dão por satisfeitos. ${ }^{354}$

\footnotetext{
353 Exemplos de casamentos: Toso, Carlo. Relazioni inedite di P.Cherubino Cassinis da Savona sul Regno del Congo e sue Missioni. 213 e 214. Frei Rafael Castello de vide. Viagem e missão no Congo, p. $124,165,23$ e 251.

${ }^{354}$ Frei Rafael Castello de vide. Viagem e missão no Congo, p. 201.
} 
No relato observamos uma estratégia interessante de ampliar (ou ressginificar) o sentido do sacramento cristão ministrado pelo padre. Através dele, constrói-se um vínculo não apenas com a ritualística católica, mas uma relação direta com o padre, utilizando este vínculo como um novo título de legitimidade política: "eles sempre ficam com o título de Compadres, ou afilhados". Desta forma, o casamento que originalmente constituía-se na oficialização do vínculo marido-mulher (que como vimos, em sua forma europeia, não caberia no Congo) tornou-se uma estratégia de vínculo com o próprio missionário.

Para além de serem ou não compadres dos padres, o sacramento do matrimônio parecia mesmo funcionar como mais um ritual de rememoração da tradição cristã, pelo qual os membros da elite política adquiriam legitimidade, e aglutinavam um novo título (que se somaria ao de marquês, duque, cavaleiro de cristo). Isso explica a aparente exclusividade dos membros das altas elites como praticantes deste sacramento.

Nos relatos de Savona e Castelo de Vide o status de "casado" aparece como evidência da ligação do membro da muana Congo com o cristianismo. Principalmente no relato do padre italiano, os nobres são apresentados neste modelo: "Os eleitores elegeram como seu rei D. Alvaro XI cristão e casado" ou "um grande marquês de nome D. Afonso Romano Leite, casado, que tem ainda o título de Rei dos Ambundos (...)". 355 A qualidade "casado" era apresentada juntamente com o nome português e os títulos, o que indica que compunha com esses elementos para demonstrar vinculação à tradição política.

Além disso, notamos que os infantes que gozam do título de "casado" passam a ter acesso privilegiado (“compadres" principalmente) aos padres, sacramentos insígnias da igreja, como vemos em Frei Rafael:

Nos outros dias me vinha visitar, e me convidava para ir a sua casa, coisa que nem todos costumam, para sua mulher legítima me tomar a bênção, e dizia ele para abendiçoar a sua casa, porque era homem casado; a que eu correspondia com agrado, e santa doutrina, e lhe dei

\footnotetext{
${ }^{355}$ Toso, Carlo. Relazioni inedite di P.Cherubino Cassinis da Savona sul Regno del Congo e sue Missioni, p. 210 .
} 
algumas coisas de devoção, coisas que eles estimam muito receber das mãos dos Padres. ${ }^{356}$

Neste caso, além de ser um importante membro da elite de Quibango, foi agraciado com a prestigiosa visita do padre a sua casa e com presentes "porque era homem casado”.

Algo que não se pode esquecer, ao tratarmos o casamento católico como um título dentre outros, é o papel da mulher nesse contexto. Para se apresentarem ao padre como candidatos ao casamento, os nobres congoleses deveriam apresentar uma (e apenas uma) noiva. Além disso, deveriam evitar que os padres tomassem conhecimento sobre a existência de outras além daquela. Savona e de Vide foram bastante flexíveis a esse respeito, não realizando investigações profundas sobre a existência de outras esposas além da escolhida para a oficialização sacramental. Frei Dicomano, ao contrário, se preocupava em observar atentamente as particularidades da poligamia congolesa, e se recusava a realizar o sacramento, ao menos que houvesse provas concretas de que o candidato tinha hábitos monogâmicos. Por isso, conseguiu realizar apenas quarenta matrimônios em muitos anos. ${ }^{357}$

De qualquer maneira, a possibilidade do casamento ser oficializado com apenas uma das esposas requeria critérios para a eleição da mesma, além de exigir o consentimento das outras esposas. Os critérios desta escolha nos são, infelizmente, inacessíveis. Vejamos um caso interessante, vivido por frei Rafael enquanto casava um importante infante na mbanza de Coma, próximo a Ensuco:

Uma delas quis mostrar o seu brio por ser desprezada, e casar com outra que ele escolheu; e quando o Infante se retirava para sua casa, já com a sua verdadeira Esposa, aquela mulher por outra parte rompia o muro com grande fúria, com um alfange na mão, cortando os paus e palhas que formavam o muro, e fazendo com os seus parentes os seus sagamentos ou brincos de guerra, como arremetendo, e dizendo que não havia de sair escondida como as outras mancebas, mas à vista de

\footnotetext{
${ }^{356}$ Frei Rafael Castello de vide. Viagem e missão no Congo, p. 43-144.

357 Correa, Arlindo. Informação o reino do Congo por Raimundo Dicomano (...), p. 4-5.
} 
todos, porque ela era Infanta, e tinha primeiro a palavra do casamento. 358

A revolta desta mulher oferece elementos interessantes para nossa discussão. Primeiramente, demonstra que de fato casar com uma das esposas não significava abandonar as outras, uma vez que estas deveriam "sair escondidas" e provavelmente voltar após a partida do padre. Em segundo lugar, notamos que para as esposas escolhidas e para sua familia (que no caso relatado protestava fazendo seus sangamentos) receber o sacramento do casamento significava o reconhecimento de poder e legitimidade. Em terceiro, evidencia o vínculo entre a identidade muana Congo e a legitimidade oferecida pelo ritual católico. $\mathrm{O}$ que aparece claramente no argumento da mulher para se afirmar a mais legítima das esposas: "porque ela era infanta”. 359

Em outros casos, infantes apresentavam dificuldades em escolher apenas uma das esposas, talvez por temerem enfrentar os mesmos percalços do homem no caso acima. Nestes casos, a legitimidade vinda juntamente com o "título" de casado poderia causar danos que colocariam em risco a reputação em outras esferas, mais "tradicionais, como a aliança com as familias de outras esposas. Eis um exemplo trazido também por frei Rafael:

(....) eles tudo prometiam mas ali [em Mbanza Nsolo próximo à Quibango] não fiz algum casamento, nem com o mesmo Príncipe pude acabar que se casasse; tendo muitas mulheres, escolhesse uma, o que me causou alguma desconsolação porque era já velho, e não podia esperar outra missão; mas isto sucede em toda a parte: uns recebem a doutrina, outros, não. ${ }^{360}$

A partir das pistas oferecidas pela documentação apontamos para o sacramento do matrimónio como um rito que conferia legitimidade política aos homens e mulheres membros da muana Congo, por ser mais um dentre os rituais de rememoração da

\footnotetext{
${ }^{358}$ Frei Rafael Castello de vide. Viagem e missão no Congo, p. 212.

${ }^{359}$ Frei Rafael Castello de vide. Viagem e missão no Congo, p. 212-213.

${ }^{360}$ Frei Rafael Castello de vide. Viagem e missão no Congo, p. 197.
} 
tradição política congolesa. Este sistema convivia, às vezes de maneira conflituosa, com as estruturas sociais organizadas pela poligamia e matrilinearidade. $\mathrm{O}$ que explica o fato do casamento ter (aparentemente) atingido praticamente com exclusividade as classes altas e o fato de ter também recebido variados graus de aceitação em diferentes localidades. ${ }^{361}$

\subsection{Nlekes, Intérpretes e Mestres: os especialistas rituais locais.}

O debate sobre o lugar ocupado pelos elementos do catolicismo (sacramentos, insígnias, padres, vocabulário, entre outros) na estrutura política do reino do Congo no período pós-unificação nos levou a concluir que os significados destes eram bastante específicos, constituindo-se elementos de rememoração da tradição político-religiosa, vinculados a uma tradição congolesa que utilizou os mesmos elementos como novas ferramentas de legitimidade para uma refundação política. É evidente que, ao identificar o lugar do catolicismo no Congo como essencialmente político não negamos a sua importância no âmbito religioso tanto para as elites quanto para a população comum em seu dia-a-dia. Como sabemos, essas esferas: religião, política e identidade são indissociáveis no Congo no período em questão (e mesmo na Europa pré-capitalista).

No capítulo anterior, argumentamos que o lugar ocupado pelos missionários europeus dentro da estrutura política e religiosa congolesa (no período pós-restauração) fora pré-determinado pela agência histórica das elites congolesas, sendo submetidos a uma relação de dependência do tipo africana. É evidente que pouco compreendiam os padres, ou se recusavam a compreender, sobre as especificidades do cristianismo e sobre seu papel no contexto local. As preocupações dos religiosos vinculavam-se a motivações internas e externas determinadas pela religiosidade europeia e pelos interesses europeus na relação com os africanos.

Essa relativa incompatibilidade entre interesses e motivações que envolviam o catolicismo e o trabalho sacramental gerou situações de conflitos e negociações, como vimos ao longo deste trabalho. Para que estes conflitos não impedissem o

\footnotetext{
${ }^{361}$ Exemplo de Oando, local no qual nobre algum aceitou casar-se (Frei Rafael Castello de vide. Viagem e missão no Congo, p. 197), em oposição à Quibango onde o casamento parecia muito popular entre as elites Frei Rafael Castello de vide. Viagem e missão no Congo, p. 204.
} 
funcionamento da estrutura política e religiosa congolesa, dependente (em diferentes graus) dos elementos católicos e dos missionários, foram personagens importantíssimos os especialistas rituais congoleses. Nlekes ("escravos" da igreja), mestres e intérpretes constituíam-se como agentes essenciais para a prática ritual cotidiana de elementos católicos no século XVIII. Estes personagens acompanhavam o trabalho missionário na corte ou interiores e por isso sua presença está registrada nas fontes, mesmo que de forma silenciosa.

No capítulo antecedente, sobre a relação do poder central com o cristianismo, debatemos a importância deste clero local na mediação de interesses entre o rei do Congo e os padres europeus. Ou mesmo como limitadores da autonomia dos missionários frente ao rei. Aqui, debateremos a importância destes como mediadores entre os interesses das elites locais e o catolicismo na prática sacramental mais direta.

Nleke é um termo recorrente na documentação quando trata dos chamados "escravos da igreja", este vocábulo é, em kikongo, um adjetivo com o sentido de juventude (que deu origem a palavra moleque no português brasileiro). Isto demonstra que estes "escravos" eram em geral jovens congoleses vinculados à igreja e o trabalho sacramental, portanto aprendizes. ${ }^{362}$ Mas não eram exclusivamente jovens; parece existir uma hierarquia entre eles na qual escravos mais velhos ocupavam local de maior prestígio. (Dicomano) Estes nlekes pareciam ter vínculo local, sobretudo em províncias onde igrejas ou hospícios eram mantidos pela elite provincial. Como no exemplo do (então inabitado) hospício capuchinho em Ensuco, descrito por Savona:

\footnotetext{
Temos o hospício de Ensuco, fundado pelo Rei Pedro III e seu avô e os escravos que estão a serviço da missão. Mas pouco se estende, não seriam 100 mil habitantes, todos cristãos. Foram sujeitos de invasores de Oando, que destruíram quase tudo, em 1765 reerguemos o hospício com os escravos da igreja e os súditos do 'paesi'.363
}

\footnotetext{
362 de vide nlekes, o missionário chega a referí-los como moleques. Frei Rafael Castello de vide. Viageme missão no Congo, p. 273.

363 Toso, Carlo. Relazioni inedite di P.Cherubino Cassinis da Savona sul Regno del Congo e sue Missioni, p. 213.
} 
Nesta descrição vemos que os "escravos da igreja" eram vinculados especificamente a esta província e a este hospício capuchinho, mas encontram-se de acordo com o padre "a serviço da missão". O vínculo de dependência fundamental dos nlekes de Encusco parecia de fato ser com os capuchinhos, como relata frei Rafael:

Ainda bem não tinha descansado, quando me mandaram pedir uns escravos dos Padres Barbadinhos Italianos, que assistiam no seu Hospício de Ensuco, dois dias de jornada desta Corte, que fosse acudir, porque não estando aqui os seus Padres, os queriam apanhar para os venderem. ${ }^{364}$

Além dos escravos da igreja dos capuchinhos de Ensuco existiam também alguns que habitava em S. Salvador, nos arredores da casa dos padres. Na ocasião da chegada dos padres da comitiva de frei Rafael à corte em 1780, os nlekes de Ensuco passaram habitar junto aos padres na capital, juntando-se a outros que haviam sido, segundo o frei, de um "vigário geral, que aqui morreu, os quais, andando dispersos, ouvindo a nossa chegada, se têm vindo ajuntar para nos servirem, e para comerem”. Recebiam também escravos de infantes que vinham à capital para receberem sacramentos ou o hábito de cristo e os mantinham como cativos a serviço da igreja. ${ }^{365}$

Enquanto os padres se encontravam na capital os nlekes eram responsáveis por lavrar as terras "que pertencem a igreja" e destas tiravam seu sustento (repartido com mestres, interpretes e padres). Trabalhavam também na construção ou manutenção de igrejas e habitação dos padres e mestres. Alguns constituíam familias (monogâmicas na aparência) e pareciam gozar de algum grau de liberdade quando não se encontravam em trabalho de missão. ${ }^{366}$ Durante as viagens, eram particularmente importantes para a manutenção da estrutura das missões. Suas funções principais eram garantir a segurança dos padres, cuidavam do material de culto e eram carregadores dos próprios padres. Assim como os outros membros das comitivas de missão, eram sustentados por "presentes" dados pela população local, principalmente as elites dirigentes em troca de

\footnotetext{
${ }^{364}$ Frei Rafael Castello de vide. Viagem e missão no Congo, p. 148.

${ }^{365}$ Frei Rafael Castello de vide. Viagem e missão no Congo, p. 220.

${ }^{366}$ Frei Rafael Castello de vide. Viagem e missão no Congo, p. 220- 221.
} 
sacramentos. ${ }^{367}$ Vale observar a interessante (e um tanto idealizada) descrição de frei Rafael a respeito da atividade cotidiana dos nlekes junto às missões:

Nas missões, nos acompanham os escravos da Igreja, que sempre o Padre leva vinte ou mais, ou pouco menos, conforme a necessidade, entre grandes e pequenos; e estes são os que lá guisam a comida, buscam água, e lenha como na Corte, e todos com o Padre vão alegres, porque na missão comem melhor, porque há mais esmolas. Têm grande zelo do seu Padre, de noite, e de dia o guardam, e Deus é servido infundir-lhe um tal respeito ao Missionário, que este se entrega livremente nas suas mãos por matos, serras e sertões, sem algum temor, e é impossível fazer-lhe algum mal, só furtar-lhe alguma coisa, para o que eles têm sua inclinação; mas são furtinhos, que o Padre disfarça muitas vezes. Algumas vezes o enfadam com gritarias entre eles, outras o divertem com as suas danças honestas, que outras the não permitimos, mas sempre se humilham à correcção, e nós os tratamos com amor como filhos, e não severos como a servos. ${ }^{368}$

Outros importantes personagens que compunham a "equipe" envolvida no trabalho ritual católico eram mestres e intérpretes. Diferentemente dos escravos da igreja estas duas categorias possuíam alto prestígio social e as teias das relações de dependência entre estes, as elites políticas e os missionários é bastante mais complexa.

Frei Rafael nos relata como padres, mestres, interpretes e escravos se distribuíam em sua morada na corte. A casa na qual habitavam os religiosos em S. Salvador ficava atrás da Santa Sé, principal e maior igreja da localidade. A casa era cercada por um alto muro e a frente da casa conectava-se com a sacristia da igreja. Os nlekes viviam no lado de fora do muro. Os padres viviam juntos na casa no lado de dentro. Segundo frei Rafael, o espaço da sacristia (conectada à casa) só poderia ser acessado por eles e pelos mestres e intérpretes, que ali trabalhavam. Ao contrário dos padres e escravos da igreja, mestres e intérpretes possuíam maior mobilidade para além do espaço da igreja. ${ }^{369}$

\footnotetext{
${ }^{367}$ Frei Rafael Castello de vide. Viagem e missão no Congo, p. 220-222.

${ }^{368}$ Frei Rafael Castello de vide. Viagem e missão no Congo, p. 224-225.

${ }^{369}$ Frei Rafael Castello de vide. Viagem e missão no Congo, p. 220-222.
} 
Os mestres catequistas no Congo remetem à tradição iniciada no reinado de D. Afonso I Mvemba a Nzinga, no início do século XVI, período em que foram inauguradas as chamadas "escolas de gramática" para o ensinar membros das elites a ler e escrever em português e ensinamentos ligados à catequese. Os primeiros mestres e intérpretes eram membros das altas elites congolesas formados em Portugal. A partir de meados do século XVI missionários jesuítas no Congo ensinavam aos congoleses a língua portuguesa e os preceitos da fé cristã. Em 1555 foi escrito o primeiro catecismo em kikongo, trabalho que certamente contou com contribuição desses primeiros mestres (africanos e jesuítas). ${ }^{370}$ No século seguinte, no ano de 1624 foi publicado pela Companhia de Jesus um catecismo intitulado "doutrina cristã", organizado pelo jesuíta Mateus Cardoso, com a colaboração, segundo o próprio, dos "melhores mestres indígenas de S. Salvador". 371

Em meados do século XVII ocorreria a crise definitiva nas relações diplomáticas entre Luanda e S. Salvador, assim como a saída completa dos jesuítas do reino, que já haviam sido expulsos em meados do século XVI, assim como a transferência da do bispado de Congo e Angola para Luanda. Diante de tais acontecimentos decisivos na relação entre Congo e Portugal (seu principal parceiro para a formação de mestres), a formação destes tomou também novos rumos. No período pós-restauração parece-nos, apesar da escassez de informações, pouco provável que os inúmeros mestres e intérpretes (e secretários dos quais falaremos a frente) tenham sido formados por portugueses em terras africanas e muitíssimo pouco provável que algum deles tenha ido à Europa. A formação se fazia dentro do Congo e de meados do século XVII ao início do XVIII parece ter sido feita (ou ao menos supervisionada) por Capuchinhos. Após a restauração em 1709, devido a quase ausência de padres desta ordem, a formação dos mestres, interpretes e secretários parece ter se autonomizado. ${ }^{372}$

Mestres e intérpretes ocupavam diferentes papéis na condução dos rituais no Congo. Infelizmente essa diferença de papéis não apresenta-se de forma clara nos relatos, que acabam centrando-se no trabalho do próprio padre e deixando de lado as

370Thornton J. K. The development of an African Catholic Church in the Kingdom of Kongo, p. 248150. Souza, Marina de Mello e. Missionários e mestres na construção do catolicismo centro-africano, século XVII. Anais do XXVI Simpósio Nacional de História - ANPUH • São Paulo, julho 2011.

371 Reginaldo, Lucilene. Os Rosarios dos Angolas. Irmandades de africanos e crioulos na Bahia Setecentista. São Paulo. Alameda 2011, p. 40-51.

${ }^{372}$ Frei Rafael Castello de vide. Viagem e missão no Congo, p. 207. 
especificidades da atuação do clero congolês. O que aparece mais evidente nas fontes é a distinção que a lógica simples seria capaz de explicitar: aos mestres cabia principalmente ensinar e, aos intérpretes, acompanhar os padres, em tese "traduzir" e "interpretar" a liturgia e a comunicação entre o padre e os congoleses. Uma leitura superficial (e ingênua) das fontes nos leva a conclusões esquemáticas sobre os papeis ocupados por cada um destes operadores rituais do catolicismo, na qual o padre ocuparia a posição central de "cérebro" da missão, enquanto infantes e mestres "braços" em sua função de divulgar e traduzir.

Se dispuséssemos apenas dos relatórios dos franciscanos Cherubino de Savona e Rafael de Vide, devido à postura tolerante e idealista de ambos (sempre preocupados em maquiar conflitos), poderíamos chegar a tal conclusão esquemática. Porém, diante da ortodoxia crítica (e do senso de superioridade) de Raimundo Dicomano recebemos diferentes impressões:

Quando se lhes explica e se lhes inculca a verdadeira ideia dos santos mistérios e dos preceitos de Deus e da Igreja não fazem caso, e muitas vezes respondem não serem esses os costumes e as leis do Congo, e que, por o Padre ser novo, não está bem instruído nas suas leis. Além disso, os próprios intérpretes de que é necessário servir-se, não se atrevem a repetir aquilo que o Padre diz contra os seus costumes, sendo mucano [delito que incorria no pagamento de multa ] para os intérpretes contradizer o que é feito universalmente por todos, porque dizem que o intérprete não deve dizer ao Padre o que fazem, e se o fazem, são castigados, (...) assim que falta o Padre, fazem-lhe pagar o mucano. ${ }^{373}$

Neste relato precioso de Frei Raimundo, notamos diversos elementos de nosso profundo interesse na análise das especificidades do catolicismo no contexto congolês pós-restauração. Primeiramente, o relato desloca a centralidade do processo de missão e ritualização católica para os mestres e intérpretes frente ao clérigo branco. É evidente que a presença do padre europeu era de importância central, como portador de grande poder simbólico e mágico. Além de que diversos sacramentos e rituais

373 Correa, Arlindo. Informação o reino do Congo por Raimundo Dicomano (...), p.6. 
tinham sua condução restrita aos padres europeus. Porém, no tocante à condução do ritual e às questões mais práticas os intérpretes ganham proeminência. Este papel não era restrito ao cuidado que a doutrina que partisse dos padres chegasse de forma inteligível aos congoleses (por tradução linguística ou cultural), mas para adaptá-la em sentido oposto, fazendo com que o padre se acomodasse à tradição congolesa e que cumprisse sua função ritual (como um nganga de altíssimo poder) de acordo com o que se esperava dele na tradição local.

Ao padre era dado o papel de principal ator no processo ritual, ao intérprete cabia a "direção" do mesmo. Pelos relatos, sobretudo de Dicomano, notamos que era esperado que o clero local limitasse a ação do padre, de acordo com os interesses das elites locais. Caso o religioso agisse contrariamente ao "que é feito universalmente por todos," eles deveriam adaptar o ritual de acordo com os "costumes e as leis do Congo". Pelo que nos informa Dicomano, este compromisso dos interpretes em agirem como interventores constituía-se uma lei local, uma vez que estava garantida a punição (mucano) para os que não o fizessem, que seria cobrada na ausência do padre.

É interessante notar as artimanhas dos congoleses para iludir o padre e garantir que ele não tomasse conhecimento sobre este sistema, que se dava sobretudo pela comunicação através dos códigos (e língua) locais, que pretendiam distanciar o padre da agência ritual.

Sobre os mestres, nota-se que exerciam uma função importante na transmissão dos saberes ligados aos rituais católicos. Nas missões, enquanto padres e intérpretes cuidavam dos sacramentos, os mestres pareciam ter o papel de ensinar cânticos, ritos, comportamentos e preceitos. Frei Rafael descreve o repertório ritual congolês, definido por ele, em diferentes situações como: "cânticos", "ladainhas" ou "rosários" proferidos pelos congoleses em quase todo o território e ensinado pelos mestres. São citados principalmente cânticos para Sto. Antônio e S. Francisco. A proeminência absoluta, porém, são as "louvações" a Nossa Senhora. Estas "ladainhas" (como são comumente descritas) eram muito recorrentes no período em diversas províncias e diferentes situações (como recepção da comitiva de missão e ritos fúnebres). ${ }^{374}$

\footnotetext{
${ }^{374}$ Frei Rafael Castello de vide. Viagem e missão no Congo, p. 25-33.
} 
Frei Rafael compartilhava com os congoleses a grande devoção a nossa Senhora e abastecia os congoleses com imagens de Nossa Senhora e insígnias para a louvação da virgem:

À noite se ajuntou o Povo a cantar o Terço de Maria SS.ma na sua língua, e a Ladainha como se costuma, a que nós assistimos, animando-os nesta santa Devoção; para o que the pus diante uma devota e perfeita imagem de Nossa Senhora da Conceição, que trazia na minha companhia, que eles não se saciavam de ver, porque não tinham no seu pobre oratório mais do que uma pouco perfeita imagem do N. P. S. Francisco, e advertia aqui, e para diante serem estes Povos devotos de Nossa Senhora, pois thes ouvia de noite, e muitas vezes de madrugada, entoar os seus louvores, os quais eu muitas vezes acompanhava animando-os com algumas práticas. ${ }^{375}$

O uso do kikongo parece ter sido hegemônico nos cânticos rituais no período da segunda metade do século XVIII. Em alguns raros momentos são descritos também cânticos em latim proferidos pelos mestres, mas estes são prioritariamente ensinados pelos padres europeus. O ensinamento do repertório ritual em kikongo cabia aos mestres, reais conhecedores dos "costumes e as leis do Congo" 376. Os mestres gozavam de maior autonomia que intérpretes e escravos da igreja, pois não encontravam-se necessariamente vinculados ao trabalho do missionário europeus. Sua presença era recorrente pelo interior do Congo, atuando de forma autônoma e em geral sustentado por membros das elites locais interessados na manutenção e rememoração da tradição católica como elemento de legitimidade. Como, por exemplo, o caso do marquês de Mbamba (de Congo) informado por Savona:

(...) e ele mantém sempre a igreja de pedra e terra e todos os sábados convoca seus vassalos mais próximos a recitarem a doutrina e santo rosário e mantém um mestre que é capaz de ensiná-la. É um bom

\footnotetext{
${ }^{375}$ Frei Rafael Castello de vide. Viagem e missão no Congo, p. 32-33.

376 Correa, Arlindo. Informação o reino do Congo por Raimundo Dicomano (...), p.6.
} 


$$
\begin{aligned}
& \text { príncipe católico e se chama D Alvaro Agua Rosada Romano } \\
& \text { Leite }(. . .)^{377}
\end{aligned}
$$

Em S. Salvador, na ultima década do século XVIII, Dicomano nos informa sobre "o costume na Cidade de S. Salvador de cantar as Ladainhas de Nossa Senhora, porque estão vivos ainda alguns Mestres antigos e uma mulher de idade que lhes paga”. 378 Em geral, estes mestres e interpretes pareciam ter origem nas elites políticas congolesas; em muitos casos os próprios chefes de mbanzas ou províncias eram também mestres ou intérpretes, o que ocorriam em geral nas localidades com maior ligação com a tradição política do reino: Soyo, Mpinda, Mucondo, Quibango, Mbamba Congo e Luvota. Esses títulos vinculados à tradição cristã eram, evidentemente, também ferramentas de legitimidade política.

Ao contrário dos mestres de períodos iniciais de contato com europeus, estes mestres tinham como principal fonte de saber a tradição local das práticas católicas, que se dava em língua local e por preceitos específicos. Frei Rafael reconheceu os cânticos de louvação à Virgem em kikongo como uma maneira de louvar a mesma santa da qual era devoto. Por isso, não hesitou em aprendê-las com os mestres e reproduzi-las à maneira congolesa:
Em obséquio desta mesma Senhora Mãe de Deus, e dos pecadores, e nossa particular protectora, faço celebrar todos os sábados em louvor da sua Imaculada Conceição, cantando o Povo o seu Rosário na Igreja; logo eu, revestido de capa de asperges, que a temos preciosa, levanto a Salve na mesma língua do Congo, e a canto com o Povo a seu modo. $^{379}$

Essa postura de frei Rafael permitiu que este pudesse trocar saberes com os mestres, aprendendo os exercícios rituais locais "a seu modo" e ensinando-os novos

\footnotetext{
377 Tradução livre: “ (...) e Lui mantiene sempre la Chiesadi Pietra, e terra, e tutti li sabati , e feste fà convocare suoi vassali più vicini, a recitare la Dottrina, e Santo Rosario, e mantiene a sue spese maestri capaci per insegnarla, e la fà da buon Principe Cattolico, e si chiama D. Alvaro Agua Rosada Romano Leite (...)" . Toso, Carlo. Relazioni inedite di P.Cherubino Cassinis da Savona sul Regno del Congo e sue Missioni, p. 210.

${ }^{378}$ Exemplos em Frei Rafael Castello de vide. Viagem e missão no Congo, p. 35, 53 e 135.

${ }^{379}$ Frei Rafael Castello de vide. Viagem e missão no Congo, p. 217.
} 
rituais em latim, principalmente aqueles que julgava úteis aos congoleses, contribuindo para aumentar também o repertório ritual dos mestres:

Logo se segue a Missão, no fim a Ladainha cantada com a antífona Tota pulchra, que eu tenho ensinado aos Mestres, e discípulos, como também o hino de Santa Bárbara todos os dias para ser nossa advogada, em terra de tantas trovoadas; e a Antífona Stella Cœli, por causa da peste, que tem havido, o que já eles fazem sofrivelmente. ${ }^{380}$

Frei Dicomano, por sua vez, assumiu uma postura completamente diferente. Recusava-se a reconhecer a condução ritual local como válida, por isso, travou constantes disputas pela legitimidade dos saberes, exaltando a hegemonia de seus preceitos europeus frente os modos locais. Consequentemente, foi bastante repreendido pelas autoridades rituais do Congo:

Porque cabe, dizem eles, aos Mestres e aos escravos idosos instruir bem o Missionário, e com minha grande aflição me foi dito muitas vezes que eu não estava bem instruído, quando os repreendia por estes preconceitos, e pela péssima vida que levavam. ${ }^{381}$

Diante desta análise das fontes do período, observamos a primazia da agência congolesa, através de seus especialistas rituais, no processo de catequese e nas práticas rituais católicas. Estes especialistas eram sustentados por membros das elites, ou eram eles próprios muana Congo, que tinham nos elementos católicos ferramentas de rememoração de sua legitimidade política e uma maneira bastante particular de ritualizar a pertença ao reino do Congo e a tradição do culto católico local.

\footnotetext{
${ }^{380}$ Frei Rafael Castello de vide. Viagem e missão no Congo, p. 217.

381 Correa, Arlindo. Informação o reino do Congo por Raimundo Dicomano (...), p 6.
} 


\subsection{Escrita, língua portuguesa e poder político}

Além do domínio da ritualística religiosa, outro saber diretamente vinculado à legitimidade e práticas do poder no Congo pós-restauração foi a escrita da língua portuguesa. Frei Rafael cita mais de uma dezena de cartas que recebeu de membros das elites locais (e mais outras tantas do Mani Congo). ${ }^{382}$ Em geral, era correspondência que pedia a presença do padre para atender à muana Congo na realização de algum sacramento específico (principalmente funerais e matrimônio, os mais praticados entre as elites), ou para auxílio na construção de igrejas. ${ }^{383} \mathrm{Em}$ outros casos poderiam ser correspondências de teor político, buscando o apoio dos missionários, ou denunciando a ilegitimidade de rivais, como ocorreu em duas ocasiões já citadas. A primeira destas foi recebida em 1781 na qual os quimpanzo de Luvota (que no período ocupavam S. Salvador) reclamavam a ilegitimidade da eleição de D. José I e pediam para que Frei Rafael abandonasse os quinlaza. ${ }^{384}$ A segunda crise ocorreu no embate entre o próprio rei Antônio II e o padre a respeito da atuação dos vilis na capital e da injúria de Bua Lau (o já citado "cachorro doido"). Neste caso o padre recebeu cartas de apoio, criticando o novo reinado dos soberanos de Soyo e de Quibango. ${ }^{385}$

Vimos no capítulo anterior como o rei do Congo utilizava as correspondências como meio de controlar a circulação do padre pelo interior. $O$ soberano recebia constantemente informações sobre o paradeiro da comitiva da missão (provavelmente reportada por interpretes e mestres) e quando era de seu interesse pedia para que mudassem os rumos, ou retornassem a S. Salvador.

Frei Rafael também lançou mão da escrita, em inúmeras situações nas quais necessitava de algum auxilio de nobres locais, sobretudo durante as viagens para 0 interior. Isso ocorria em casos de percalços gerais, doenças ${ }^{386}$, travessia de $\operatorname{rios}^{387}$,

\footnotetext{
382 Exemplos em Frei Rafael Castello de vide. Viagem e missão no Congo, p. 63, 80, 83, 117, 174, 198, 233, 258, 287, 296.

383 Toso, Carlo. Relazioni inedite di P.Cherubino Cassinis da Savona sul Regno del Congo e sue Missioni, p. 211.

${ }^{384}$ Frei Rafael Castello de vide. Viagem e missão no Congo, p. 80, 83.

${ }^{385}$ Frei Rafael Castello de vide. Viagem e missão no Congo, p. 293-296.

${ }^{386}$ A um capitão da igreja de Mbamba: Frei Rafael Castello de vide. Viagem e missão no Congo, p. 244.

${ }^{387}$ Ao mesmo infante de Mbamba: Frei Rafael Castello de vide. Viagem e missão no Congo, p. 244-245.
} 
carência de alimentos ${ }^{388}$, ou simplesmente pra anunciar a data de sua chegada ${ }^{389}$. Os que recebiam tais correspondências eram membros da Muana Congo da confiança de Frei Rafael: em geral seus compadres, afilhados, mestres ou cavaleiros de Cristo. ${ }^{390}$

Além dos muana Congo que liam e escreviam, existiam alguns que dispunham de secretários profissionais para escrever cartas. Mesmo alguns infantes que dominavam a escrita poderiam dispor deste alto funcionário, que certamente eram eles próprios membros das altas elites. Infelizmente, não conseguimos precisar a recorrência destes funcionários como escreventes frente os próprios infantes. É certo que os reis sempre dispunham de um ou mais secretários, e o mesmo deveria ocorrer com os dirigentes das principais províncias. Eles aparecem como membros importantes nas comitivas dos soberanos locais, ao lado dos mesmos. ${ }^{391}$

Frei Rafael descreve um interessante personagem, um secretário chamado D. Francisco de Vasconcelos, que trabalhava para D. Pedro (não conhecemos o nome em kikongo), "príncipe de Quimbago". Sobre este secretário encontramos informações privile giadas:

(...) do que se passou, falarei adiante: a carta do Infante, que era a resposta de outra, que eu the havia escrito prometendo-lhe ir à sua Banza que também já era resposta de outra que ele me tinha escrito pedindo-me isto mesmo, vai inclusa nestes papéis, e é letra de um seu secretário, que é um preto que estudou em Luanda para se ordenar, mas ao depois teve algum impedimento ou por morte de seu Pai, ou semelhante causa, e é a melhor pena e bom Português. ${ }^{392}$

Este personagem se destaca, pois o missionário decidiu incluir em seu relatório uma carta escrita por ele, em nome do príncipe que Quibango. A versão do documento que dispomos é uma cópia feita por Frei Vicente Salgado em 1794, por isso, infelizmente não temos acesso à carta manuscrita do secretário, o que nos impossibilita

\footnotetext{
${ }^{388}$ Frei Rafael Castello de vide. Viagem e missão no Congo, p. 59.

${ }^{389}$ Ao príncipe de Quibango: Frei Rafael Castello de vide. Viagem e missão no Congo, p. 205.

${ }^{390}$ Frei Rafael Castello de vide. Viagem e missão no Congo, p. 205, 305 e 308.

${ }^{391}$ Frei Rafael Castello de vide. Viagem e missão no Congo, p. 207.

${ }^{392}$ Frei Rafael Castello de vide. Viagem e missão no Congo, $p .80,83$.
} 
de observar detalhes da ortografia e caligrafia. De qualquer forma, o documento pode ser interessante para compreendermos melhor para desvendarmos o papel destes secretários.

A carta pode ser dividida em duas partes. A primeira com a mensagem de seu "senhor" ao padre (provavelmente ditada por ele em português, por se tratar de um nobre de Quibango) e em seguida o secretário faz um adendo, com uma mensagem pessoal ao padre em seu próprio nome. Acreditamos ser um documento muitíssimo precioso, portanto, o citaremos por inteiro:

Ao M. R. P. Vigário Geral do Congo, Fr. Rafael de Castello de Vide, a quem Deus guarde, m. a. Faço este meu escrito para mandar saber a sua saúde; sendo boa, eu folgarei muito, enquanto da minha estou bem pela misericórdia de Deus, ainda que misturado com muitas mortes da gente de Deus por esta grande peste, mas encomendamos a Deus todo poderoso, por ouvir a sua chegada a V.P. deste cume do Monte do Quibango, não posso calado assim sem mandar buscar a Sagrada Pessoa de V. P. pela vir, e nos dar os Santos documentos ${ }^{393}$, porque esta Igreja de Quibango é a vossa verdadeira Igreja, que edificou: os defuntos Padres eram seus irmãos; não posso fartar a seu, e amor desta Igreja: não largo mais: hoje, dia de Santo António de 1787, o seu filho espiritual, Dom Pedro agora R. da Sardónia, Príncipe de Quibango.

O seu afilhado, Mestre, Secretário, D. Francisco de Vasconcellos mando beijar mil vezes as mãos de V.P., ainda que eu não estou bem, por causa de minha doença antiga, também fico com grande nojamento por tantas mortes de meus parentes e filhos, e irmãos e sobrinhos, neste mesmo mês passado de Maio, mas tudo isto encomendei a Deus Nosso Senhor, porque tudo e quanto faz a Deus, é por nosso bem. ${ }^{394}$

\footnotetext{
${ }^{393}$ O texto manuscrito leva também o termo "documentos" onde parece caber a palavra "sacramentos", não sabemos se foi um erro do copista Frei Vicente, do próprio secretário ou se de fato desejava receber algum "sagrado documento", o que não é completamente improvável, uma vez que junto aos saberes da escrita e catequese havia também a circulação dos textos sagrados.

${ }^{394}$ Frei Rafael Castello de vide. Viagem e missão no Congo, p. 308, 309.
} 
É interessante notar que o secretário acumula elementos de legitimidade em sua apresentação: afilhado, Mestre e Secretário (além do próprio Dom e o nome em português). Parece ter sido comum a existência de secretários que também eram mestres, o que indica que a estes também cabia o ensino da escrita para membros das elites políticas. D. Francisco é um exemplo de secretário que estudou em Luanda, mas acreditamos existir no Congo do período, mecanismos de transmissão desses saberes, provavelmente através dos mesmos mestres, certamente não sendo dependentes das estruturas eclesiásticas lusas, como em períodos anteriores à restauração.

A historiadora portuguesa Catarina Madeira Santos publicou recentemente um instigante trabalho que relaciona escrita e poder político no Ndembu, trerritório vizinho ao Congo que possui fortes ligações culturais e identitárias com este reino. O caso desta sociedade difere do Congo, pois a escrita foi introduzida num contexto de contratos de Vassalagem com Luanda ainda no século XVII, nos quais, os documentos escritos constituíam-se como elementos centrais, e por isso tornavam-se também elementos de poder político. A autora investiga a incorporação da escrita como ferramenta de poder político e como uma "tecnologia" que reinventou a estrutura de poder de Ndembu, possibilitando um certo grau de burocratização das estruturas políticas. A investigação da historiadora vai além e busca compreender como esta incorporação, além de gerar transformações políticas, transformou também a própria escrita. Além da função social e política da escrita, a pesquisa nos mostra como as estruturas lexicais, pontuação, ortografia e caligrafia foram reinventadas pelos africanos num contexto próprio e interesses particulares, gerando assim uma bricolagem linguística entre o português, quimbundo e kikongo. Após sua reinvenção, a escrita (segundo a autora) passou a exercer uma função específica no interior daquela sociedade. A troca de correspondências passou então a ser recorrente entre as elites locais e o ndembu (soberano) para atender demandas destas elites. ${ }^{395}$

No ndembu os secretários possuíam papel fundamental dentro da gramática de poder. Estes secretários eram bastante especializados, em geral estrangeiros (às vezes enviados por Luanda) formados na região do presídio de Ambaca, onde existia uma "escola" responsável pela formação de africanos (de maioria ambunda) ou mestiços nos saberes da leitura, escrita e religião. Estes "ambaquistas" (como eram chamados) eram

\footnotetext{
395 Santos, Catarina M. Écrire le pouvoir en Angola. Les archives ndembu (XVIIème-XXème siècles), Annales, Histoire Sciences Sociales, 64e année, nº, p.767-795.
} 
bastante prestigiados nos territórios avassalados, ou naqueles que possuíam maior relação (mesmo que conflituosa) com Luanda. ${ }^{396}$

Infelizmente, não dispomos de nenhuma das inúmeras cartas escritas pelos congoleses das quais temos notícia pelo relato de Frei Rafael (com exceção da cópia citada e transcrições de cartas do Mani Congo D. José I). O Mani Congo não parece ter constituído um arquivo de estado, como fizeram os ndembu, e se o fez ele se perdeu. $\mathrm{O}$ trabalho de identificação e recolha destes documentos de autoria congolesa ainda está em aberto e abriria profícuo campo para o acesso à especificidade congolesa que perseguimos.

Porém, os instigantes resultados da pesquisa de Catarina Madeira Santos podem apontar alguns caminhos no debate sobre a escrita no reino do Congo. Primeiramente, notamos significativas diferenças do Congo com relação ao Ndembu, devido a suas particularidades históricas.

Ao contrário do Ndembu, o Congo foi absolutamente independente de Luanda até no mínimo meados do século XIX. Se no território Ndembu do século XVIII os tratados de vassalagem com Luanda eram essenciais para as estruturas internas de poder, no Congo isso não ocorreu (lembramo-nos da interdição quase absoluta da circulação de portugueses e ambundos citada pelas nossas fontes e da estratégia da Coroa portuguesa na vinculação da missão com o retorno à parceria, que falhou). Ora, isso por si só, permite que vislumbremos sentidos bastante diferentes da escrita no Congo, onde a troca de correspondências (desde D. Afonso I em 1509) foi um elemento importante que aproximava nações estrangeiras: inicialmente Portugal e mais tarde: Roma, holandeses, ingleses, e talvez espanhóis e franceses, entre outros. ${ }^{397}$

No século XVIII, a importância da parceria com não-portugueses era bastante mais significativa para os reis do Congo. Por isso, desde períodos iniciais, a escrita no Congo sofreu uma naturalização entre as elites. Ao contrário das elites ndembu os muana Congo (em sua maioria) não pareciam dispor (tampouco necessitar) de secretários estrangeiros, os seus membros mais prestigiosos liam e escreviam o

\footnotetext{
${ }^{396}$ Santos, Catarina M. Écrire le pouvoir en Angola, p.767-772.

397 Caso da parceria com holandeses: Mosterman, Andrea e Thornton, John K. A Re-interpretation of the Kongo-Portuguese War of 1622, p. 236-242. Caso da influência inglesa: Broadhead, Susan H. Trade and Politics on the Congo coast, p. 114.
} 
português. Isso se deu devido à longa tradição de letramento das elites congolesas iniciada com D. Afonso I, que passou pela presença jesuítica no XVI, capuchinha no XVII e parece ter se desenvolvido para uma significativa autonomia no XVIII. Além disso , segundo Jill Dias, os secretários formados em Ambaca possuíam uma marca indenitária "europeizada", vestindo-se e comportando-se nos moldes lusitanos, o que parece incompatível aos modos das elites congolesas no século XVIII. ${ }^{398}$

Segundo Catarina Madeira Santos, os portugueses eram, para o Ndembu, um "referencial do colonizador", uma vez que constituíam-se como uma potencia comercial, política e referência em termos de literacia e burocratização do estado. ${ }^{399}$

O Congo foi, assim como Portugal, um estado politicamente imponente, no qual as elites lançavam mão da escrita há séculos. Catarina Madeira Santos não explorou a possibilidade da escrita fazer referência também ao Congo para as elites ndembu. Mesmo assim cita correspondências entre o ndembu e o rei do Congo Alvaro XIII, em 1857, nas quais o Mani Congo aconselha o vizinho a abandonar a parceria com os portugueses, e promete uma intermediação com o rei inglês, definido como seu amigo. Além do mais, a ligação com “ nosso soberano, e pai, Rei do Congo" é invocada pelos ndembu como argumento de defesa contra a sanha comercial portuguesa. ${ }^{400}$ Ora, parece sugestivo que o Congo constituísse também um referencial em termos de escrita para os ndembus, e que o letramento desta elite abriria também possibilidade de comunicação com as elites vizinhas e poderosas do reino do Congo. Não parece improvável que houvesse algum secretário congolês, ou formado no Congo, trabalhando para o ndembu, visto a parceria entre eles e a presença de um secretário congolês (chamado D. Calisto Zelotes dos Reis Magos) na mais longínqua (cultural e espacialmente) corte da rainha Nzinga no século XVII, segundo pesquisa de Marina de Mello e Souza. ${ }^{401}$

\footnotetext{
${ }^{398}$ Dias, Jill R. Novas identidades africanas em Angola no contexto do comércio atlântico, p. 326-339.

${ }^{399}$ Santos, Catarina M. Écrire le pouvoir en Angola, p.767-772.

${ }^{400}$ Santos, Catarina M. Écrire le pouvoir en Angola, p.770-772.

401 Souza, Marina de Mello e. Missionários e mestres na construção do catolicismo centro-africano, século XVII. Anais do XXVI Simpósio Nacional de História. ANPUH. São Paulo, julho 2011.
} 
Em suma, para além destas especulações, a leitura do trabalho de Catarina Madeira Santos, e a observação do contexto da literacia no Congo, aponta para a existência de uma rede de comunicação escrita composta pelas elites locais centroafricanas que, ao menos no Congo e ndembu, funcionava de forma absolutamente autônoma e a partir de lógicas próprias.

Neste capítulo apresentamos a organização provincial, discorrendo sobre cada uma das principais províncias. Argumentamos que a organização política do Congo no período pós-restauração era extremamente complexa e constituía-se como uma unidade em novos termos, em relação a períodos anteriores. Mesmo que as práticas de sujeição das províncias não se dessem da mesma maneira que no período do poder centralizado, a rememoração deste período tornou-se elemento essencial para a identidade política congolêsa. Por isso, mesmo permitindo diversos graus de autonomia e de especificidades regionais, o Congo continuou constituindo-se uma unidade política no período pós-restauração. O poder do rei era essencialmente simbólico e identitário, o que demonstra a importância que a identidade ligada ao reino do Congo assumia para as elites congolesas. As práticas rituais católicas entre as elites (como o casamento) nas províncias constituíam-se como elementos que ligavam os chefes locais à tradição e à identidade congolesa, o que conferia enorme legitimidade aos mesmos.

Além disso, a atuação dos especialistas congoleses nas práticas ligadas ao catolicismo, língua portuguesa e escrita: nlekes, mestres, intérpretes e secretários, neste contexto nos mostram que a agência africana constituiu-se como alicerce deste sistema político centrado numa identidade política congolesa. 


\section{Considerações Finais}

Vimos no primeiro capítulo que a historiografia que se debruçou sobre o reino do Congo em períodos anteriores à restauração política realizada por Pedro IV em 1709 se dividiu em duas principais vertentes, que lançam mão de diferentes estratégias teórico-metodológicas para desvelar as especificidades da relação dos congoleses com o catolicismo. São duas diferentes perspectivas sobre a "africanização" do catolicismo no reino do Congo.

A primeira, influenciada pelos trabalhos antropológicos contemporâneos, (principalmente de MacGaffey) ${ }^{402}$ destaca a ideia de "tradução" cultural. Ela se debruçou sobre a "cosmologia" ou "cosmogonia" dos bacongo contemporâneos e a partir dela oferece possíveis interpretações dos sentidos que os elementos católicos (originalmente europeus) teriam recebido no Congo. Devido ao uso de trabalhos de campo realizados por estudiosos preocupados em compreender as visões de mundo africanas, esta vertente teve acesso privilegiado ao "idioma original", através do qual, segundo estes estudiosos, houve constante reinterpretação dos termos católicos de origem europeia. ${ }^{403}$

Uma segunda vertente, representada principalmente por Thornton, oferece maior resistência em utilizar trabalhos antropológicos, pois acredita que as fontes históricas seriam as vias privilegiadas na busca dos sentidos da incorporação do catolicismo. Para Thornton, o catolicismo integrou-se ao sistema religioso e político congolês durante as primeiras décadas de contato. Isso ocorreu, segundo ele, graças às semelhanças que os dois sistemas (culturais e políticos) apresentavam no início do século XVI. Essas similitudes possibilitaram a formação de um "catolicismo nacional congolês", que possuía suas especificidades, porém compatível com os outros "catolicismos" europeus. 404 Em trabalho mais recente (juntamente com Heywood) Thornton denominou este catolicismo de "crioulo". 405

\footnotetext{
402Macgaffey, Wyatt. Dialogues of the deaf: Europeans on the Atlantic coast of Africa. 1996.

403 A primeira estudiosa a realizar tal abordagem histórico-cosmológca foi Anne Hilton: Hilton, Anne. The Kingdom of Kongo. 1985.

404 Thornton J. K. The development of an african Catholic Church in the Kingdom of Kongo, p. 150-165. 405Heywood, Le Thornton J. Central African Creoles and The Foundation of the Americas, p. 135-143.
} 
Há, para esta vertente historiográfica, uma ideia de incorporação (e adaptação), pelos congoleses dos padrões europeus. Não se trata, porém, de uma incorporação que se deu por aculturação ou imposição de um lado ao outro. Para essa linha de interpretação, Portugal e Congo eram (no século XVI) muito semelhantes na estrutura política, em seu "desenvolvimento" econômico e em seu poderio militar. Portanto, para Thornton, a incorporação do catolicismo teria sido possibilitada por uma igualdade de condições e pelo interesse e agência das elites congolesas.

Nossa opção em debater estas escolas historiográficas no início da dissertação deveu-se à necessidade de explicitar as diferentes abordagens adotadas pelos estudiosos que trataram da mesma região e de temas semelhantes aos aqui abordados. Porém, as especificidades do período de nosso recorte cronológico (quatro ultimas décadas do século XVIII) em relação aos períodos anteriores, nos obrigaram a buscar os sentidos "africanizados" do catolicismo por um viés de transformações históricas internas à própria lógica congolesa. Ao contrário do tempo dos primeiros contatos; no período pós-restauração a tradição da relação com os elementos católicos dizia respeito ao próprio Congo, e não mais a um sistema estrangeiro. Na data de chegada de Frei Cherubino de Savona: 1769, que marca o início de nossa cronologia, os elementos do catolicismo estavam presentes no Congo há quase trezentos anos, sofrendo e impondo diversas transformações.

Além disso, como mostramos no capítulo II, a relação entre Congo e Portugal era completamente diferente no século XVIII do contexto do século XVI (até meados do XVII). Vimos que a parceria privilegiada entre reinos irmãos havia se rompido nos âmbitos da fé e do comércio. No tocante ao catolicismo, desde meados do século XVII, após a transferência da diocese de Congo e Angola para Luanda e expulsão (definitiva) dos jesuítas, o Mani Congo passou a receber padres capuchinhos através de uma parceria direta com a Congregação da Propaganda Fide, ligada diretamente ao papado, política que foi fruto de uma dupla intenção (do Mani Congo e do Papa) em quebrar o monopólio lusitano sobre a missionação na região.

No plano econômico, a hegemonia portuguesa também fora perdida na costa centro-africana em meados do século XVII, pois presença de holandeses, ingleses e franceses tornou-se cada vez mais constante, sendo absolutamente hegemônica em portos congoleses no século XVIII. Como nos mostrou Broadhead: a fragmentação política e econômica do Congo e a presença de novas nações europeias foram fatores 
que se potencializaram mutuamente. A partir deste processo, passou a vigorar um novo sistema econômico extremamente fragmentado no qual mercadores de diversas nacionalidades europeias (protestantes em sua maioria) estabeleceram parcerias pontuais com chefes provinciais congoleses e grupos de mercadores africanos (como os vilis) que traziam escravos das feiras ao interior. Este sistema não se encontrava mais submetido ao controle direto do Mani Congo e tampouco dos portugueses. Em novo contexto pós-restauração, portanto, esvaziou-se de sentido o binômio: parceria na fé / parceria no comércio, que marcou a relação entre Congo e Portugal no período de centralização do poder, essencial para a compreensão dos sentidos do catolicismo no Congo em períodos iniciais.

No âmbito da política interna, as especificidades no período em questão são muitas. O poder do Mani Congo foi restaurado em 1709, mas gerou uma nova lógica. O rei já não podia mais recuperar a ascendência tributária e militar sobre as chefaturas locais. Por isso, o pertencimento a esse novo sistema político passou a ser cimentado pela identidade ligada à tradição do poder centralizado. Esta identidade dizia respeito (em alguns casos) à ancestralidade comum do fundador mítico Lukeni dia Nimi, mas essencialmente dizia respeito ao "refundador" (ou novo fundador) do sistema político no Congo: D. Afonso I Mvemba a Nzinga. Como argumentamos ao longo deste trabalho, D. Afonso tornou-se ao longo do século XVIII, o principal referencial de identidade e da organização política no Congo.

Expusemos no capítulo III que a legítima eleição do rei, assim como o usufruto dos títulos de marquês, príncipe e duque pelos regentes locais eram direitos exclusivos dos descendentes diretos de D. Afonso I, que compunham a chamada muana Congo. Ser muana Congo ("infante" ou "infanta") era o principal critério de legitimidade política para as elites no período, mesmo em províncias distantes e formalmente autônomas. Vimos também que os elementos do catolicismo foram essenciais para que os membros da muana Congo ritualizassem cotidianamente sua pertença a esta classe política. Esta ocorria através da presença do padre, mestres, intérpretes e secretários nos territórios onde moravam as elites; pelo sacramento do batismo dado aos súditos dos infantes; pelo casamento de um muana Congo com uma de suas mulheres; pelo conhecimento de um infante da língua portuguesa e dos saberes ligados ao cristianismo; pela celebração de missas nos territórios destes soberanos, dentre outros. 
Assim como nos períodos dos primeiros contatos entre congoleses e portugueses, os missionários europeus continuaram a ser importantes dentro do sistema político-religioso. Porém, no contexto pós-restauração este papel encontrava-se reinventado. Após a escassa presença de missionários durante todo o século XVIII, os especialistas católicos locais (mestres, intérpretes e nlekes) passaram a ocupar lugar de maior centralidade na celebração sacramental, o que fez crescer o grau de autonomia da ritualística e dos saberes católicos em relação aos missionários europeus, como apresentamos no quarto capítulo.

Além disso, o Mani Congo assumira, após a restauração do poder, postura mais reguladora em relação aos missionários. Em contextos anteriores, como no início do século XVIII (pouco antes da restauração política) Pedro IV Nessamo a Mbandu dependia dos capuchinhos presentes no Congo para legitimar-se, uma vez que o apoio dos padres era essencial no contexto interno para que o Nessamo fosse capaz "costurar" alianças políticas, afirmar-se rei do Congo e finalmente se estabelecer na capital S. Salvador. Por isso, o (então candidato a) rei via-se obrigado a fazer concessões aos religiosos, que por isso gozavam de maior autonomia. Estes capuchinhos mais ortodoxos visavam controlar a execução dos rituais católicos e reprimir quaisquer práticas que não fossem cristãs.

Após a restauração e a implementação do sistema rotativo entre as makanda quimpanzo e quinlaza, iniciou-se um período de maior estabilidade e o Mani Congo voltou a figurar como principal autoridade (simbólica). Neste contexto os padres europeus continuaram a gozar de grande prestígio, porém perderam autonomia em relação ao rei. Debatemos no capítulo 3 que nas ultimas décadas do século XVIII os padres encontravam-se tolhidos pelo Mani Congo e se submetiam a ele numa relação de dependência de caráter africano, diferentemente do tipo de vínculo que possuíam em seus reinos católicos natais. Ainda sobre a autonomia missionária, observamos no capítulo 3, como os especialistas rituais locais (principalmente mestres e intérpretes) lançavam mão de estratégias para centralizar as práticas ritualísticas cristãs por eles adaptadas, para que o padre se submetesse às praticas que se tornaram costumeiras e características do Congo.

As especificidades históricas do período pós-restauração nos impuseram um olhar privilegiado para as transformações. Concluímos que o complexo sistema político congolês constituiu uma unidade política entre as províncias que já não dispunha mais 
dos alicerces de períodos de centralização. Por este motivo, a identidade política comum tornou-se dependente da lembrança (e ritualização) de um passado "glorioso" e dos ancestrais que lá viveram. Como é característico do conceito de tempo "mítico" africano, o presente tornou-se um exercício de repetição e rememoração do passado ancestral, num processo que necessitava mutuamente do presente e do passado, dos viventes e dos ancestrais. No Congo, os elementos do catolicismo cumpriram, de acordo com o que esta pesquisa pretendeu mostrar, o papel de "ponte" entre a tradição e a inovação política.

Suzan Herlin Broadhead, em sua tese sobre o Congo nos séculos XVIII e XIX, privilegiou um olhar para o comércio como fator para compreender a estrutura política. Apesar desta autora ter admitido a importância do catolicismo para manutenção da identidade congolesa no período, ela decidiu priorizar os fatores econômicos em sua análise. Devido ao vinculo que estabelece entre comércio e política, seu trabalho conclui que a política congolesa se fracionou em pequenas chefaturas ligadas ao tráfico de escravos ("broker states") e que mesmo mantendo uma identidade comum, o Congo fragmentou-se politicamente. ${ }^{406}$

O olhar privilegiado para os elementos do catolicismo como ferramenta política nos permitiu vislumbrar um sistema de poder que, após a restauração em 1709, voltou a ser unificado em torno do Mani Congo. O fator econômico perdeu centralidade como mantenedor da unidade política (uma vez que ocorreu a fragmentação comercial) e deu maior espaço aos fatores simbólicos e identitários ligados à tradição política dos tempos de centralização. Ao elencarmos o fator simbólico-identitário como referencia para a análise histórica, concluímos que não houve fragmentação (em sentido absoluto) da antiga unidade política, tampouco enfraquecimento da relação entre S. Salvador e as províncias. Pelo contrário, a unidade se manteve e se fortaleceu sob novas bases, fundando um novo paradigma político. Esse processo evidencia o caráter fluido e complexo da organização política do reino do Congo, que sobreviveu por quatro séculos às muitas transformações históricas, ancorando-se simultaneamente na tradição e na inovação.

\footnotetext{
${ }^{406}$ Broadhead, Susan H. Trade and Politics on the Congo coast, p.53-60.
} 


\section{Bibliografia Geral}

Alencastro, Luis Felipe de. O Trato dos Viventes: formação do Brasil no Antlântico Sul, séculos XVI e XVII. São Paulo, Cia das Letras, 2000.

Balandier, G. Daily life in the Kingdom of Kongo. Nova Iorque, Meridian books, 1969.

Broadhead, Susan H. Trade and Politics on the Congo coast. 1790-1890. Phd Thesis. Boston University. 1971

Beyond Decline: The Kingdom of the Kongo in the Eighteenth and Nineteenth Centuries. The International Journal of African Historical Studies, Vol. 12, No. 4. Boston, Boston University African Studies Center, 1979. p. 615- 650

Cuvelier, Jean L'Ancién Royaume de Congo, Bruxelas, 1946 Nkutama amnvila za makanda, Tumba, Congo, 1934.

Dias, Jill R. Novas identidades africanas em Angola no contexto do comércio atlântico. In: Bastos, Cristina; Almeira, Miguel e Feldmer-Bianco, Bela (orgs). Trânsitos Coloniais. Diálogos Críticos Luso-Brasileiros. Campinas. Ed. Unicamp, 2009, p. 315396.

Ferronha, António Luís Alves. Cartas de D. Afonso Rei do Congo. Lisboa. Comissão pela Comemoração dos Descobrimentos Portugueses, 2000.

Fomont, Cecile A. Under the Sign of the Cross in the Kingdom of Kongo: Shaping Images and Molding Faith in Early Modern Central Africa. Phd thesis. Cambridge, Harvard University. 2008.

Gonçalves, Rosana A. África Indômita. Missionários Capuchinhos no Reino do Congo (século XVII). Dissertação de mestrado em História Social. Universidade de São Paulo, São Paulo, 2008.

Heywood, Linda(org) Central Africans and Cultural Transformations in the American Diaspora. Cambridge, Cambridge University press, 2002. 
Heywood, Linda e Thomton J. K. Central African Creoles and the Foundation of the Americas, 1585-1660. Cambridge, Cambridge University Press, 2007.

Hilton, Anne. The kingdom of Kongo. Oxford University Press. 1985

Reviewed work: La symbolisation politique. Le 'prophetisme' Kongo au XVIIIeme siecle. The Journal of African History, Vol. 26, No. 4. Cambridge, Cambridge University Press, 1985, p. 439-439.

Levi-Strauss, Claude. As estruturas elementares do parentesco. Petrópolis, Vozes, 1982.

O pensamento Selvagem. São Paulo, Papirus, 2008

MacGaffey, Wyatt. Religion and Society in Central Africa: The Bakongo of Lower Zaire. Chicago, Chicago Univ. Press, 1986.

Dialogues of the deaf: Europeans on the atlantic coast of Africa. In: Schuwatz, S. Implicit Understandings. Observing, reporting, and reflecting on the encounters between Europeans and other peoples in the Early modern era. Cambridge, Cambridge Univ. press, 1996.

The Religious Commissions of the Bakongo . Man, New Serie. Vol.

5, No. 1. Royal Anthropological Institute of Great Britain and Ireland. Man, New Series, 1970 , p. 27-38

Complexity, Astonishment and Power: The Visual Vocabulary of Kongo Minkisi. Journal of Southern African Studies, Vol. 14, No. 2, Special Issue on Culture and Consciousness in Southern Africa, Oxford, Oxford University, 1988, p. 188-203.

Changing representantions in central African History. Journal of African History, n 46, pp. 189-207. Cambridge, Cambridge Univ. Press, 2005

M'Bokolo, Elikia. África Negra: História e Civilizações-Tomo I-Até o século XVIII. São Paulo, Edufba/ Casa das Áfricas, 2009.

Randles, W.G.L. L'ancién royaume du Congo, Paris, 1968. 
Reginaldo, Lucilene. Os Rosarios dos Angolas. Irmandades de africanos e crioulos na Bahia Setecentista. São Paulo, Alameda, 2011.

Saussure, Ferdinand: Cours de linguistique générale. Paris, Payo, 1916.

Santos, Catarina M. Écrire le pouvoir en Angola. Les archives ndembu (XVIIèmeXXème siècles). Annales, Histoire Sciences Sociales, 64e année, nº 4. Paris, p.767-795.

Swchartz, Stuart. Cada um na sua lei. Tolerância religiosa e salvação no mundo atlântico ibérico. São Paulo, Cia das Letras, 2009.

Souza, Marina de Mello e. Reis negros no Brasil escravista, Belo Horizonte, Ed. UFMG, 2003.

Central Africans crucifixes. A study of symbolic translations. In: Jay A.Levenson. (Org.). Encompassing the Globe. Portugal and the World in the 16th and 17th Centuries. Essays. Washington DC, Smithsonian Institute, 2007, p. 97-100. Missionários e mestres na construção do catolicismo centro-africano, século XVII. Anais do XXVI Simpósio Nacional de História, ANPUH, São Paulo, 2011.

Tengarrinha, José (org) História de Portugal. São Paulo, Edunesp, 2001

Thomton, John K. The Kingdom of Kongo. Civil war and transition. 1641-1718. Madison, Winsconsin Univ. press, 1983.

The Kongolese Sant Anthony. Dona Beatriz Kimpa Vita and the Anthonian moviment, 1984-1706. Cambridge, Cambridge University press. 1998.

Elite women in the kingdom of Kongo: Historical perspectives on women's political power Journal of African History, 47, Cambridge University Press. 2006. p. 437-60.

Early Kongo Portuguese relations: a new interpretation. History in Africa. V 8. New Jersey, African Studies Association, 1981, p. 183-204.

The origins and early History of the Kingdom of Kongo, 1350-1550". International Journal of African Historical Studies, Vol 34, No. 1 . Boston, African Studies Center-Boston University, 2001. 
The development of an Arican Catholic Church in the Kingdom of Kongo, 1491-1750. The jornal of African History. Cambridge, Cambridge University Press, 1985, p. 147-167.

A Note on the Archives of the Propaganda Fide and Capuchin Archives. History in Africa. New Jersey, African Studies Association. Vol 6. 1779, p. 341-334.

New Light on Cavazzi's Seventeenth-Century Description of Kongo. History in Africa. New Jersey, African Studies Association. Vol 6. 1979, p. 253-264. Demography and History in the Kingdom of Kongo, 1550-1750. The Jornal of African History, vol 18, issue 4. Cambridge, Cambridge University Press, 1977 , p. 507-530.

Origin traditions and history in Central Africa. African Arts. V. 34. Los Angeles, UCLA African Studies Center, 2004, p 32-39.

Portuguese-African relations, 1500-1750. In: Jay A.Levenson. (Org.). Encompassing the Globe. Portugal and the World in the 16th and 17th Centuries. Essays. Washington, Smithsonian Institution, 2007, p. 57-65

Van Wing, Joseph: Etudes Bakongo. s/e. Bruxelas, 1921.

Vansina, Jan. Kingdoms of the Savana. Madison, Winsconsin University Press, 1966. Oral Tradition as History. Madison, Wisconsin University Press, 1985. Anthropologist and the third dimension. Journal of the International African Institute, Vol. 39, No. 1. 1969, p. 62-68.

Portuguese vs Kimbundu : Language Use in the Colony of Angola (1575 - c. 1845) in Bull. Séanc. Acad. r. Sci. Outre-Mer Meded. Zitt. K. Acad. Overzeese, p. 267-281 Art History in Africa, an Introduction to the. New York, Longman, 1999.

Wissenbach, Maria Cristina C. As Feitorias e Urzela e o tráfico de escravos: Georg Tams, José Ribeiro dos Santos e os Negócios da África Centro-ocidental na década de 1840. Afro-Ásia, n 43. Salvador, CEAO- UFBA, 2011, p. 43-90.

Entre caravanas de marfim, o comércio da urzela e o tráfico de escravos: George Tams, José Ribeiro dos Santos e os negócios da África centro-ocidental 
na década de 1840. Programa Nacional de Apoio à Pesquisa - FBN/MinC , 2008, p. 29 36.

Disponível

eletronicamente

em:

http://www.bn.br/portal/arquivos/pdf/MariaCristinaCortez.pdf

\section{Fontes primárias:}

Arquivo Histórico Ultramarino (AHU) papéis de angola, caixa 70, documentos 8, 23, $28,27$.

Arquivo Histórico Nacional de Angola. (AHNA)-17-5 Oficios para Angola, fol. 67v. Barão de Mossamades para Antônio II, Agosto de 1787.

Brásio, Antônio: Informação do Reino do Congo, de Frei Raimundo de Dicomano, em Revista Studia, XXXIV Lisboa, 1972.

Esse documento possui uma outra tradução, melhorando alguns aspectos da tradução de Brásio por Arlindo do Corrêa: http://www.arlindo-correia.com/101208.html

Arlindo, Correa. Informação o reino do Congo por Raimundo Dicomano (1798). 2008. Publicado eletronicamente em: http://www.arlindo-correia.com/101208.html. Informazione sul regno del Congo di Fra Raimondo da Dicomano 1798). 2008. Publicado eletronicamente em: $\underline{\text { http://www.arlindo- }}$ $\underline{\text { correia.com/121208.html }}$ Viagem e missão no Congo de Fr. Rafael Castelo de Vide (17801788).2007. Publicado eletronicamente em: http://www.arlindocorreia.com/161007.html O Missionário e o Negócio. 2007. Publicado eletronicamente em: http://www.arlindo-correia.com/041207.html

Frei Rafael Castello de Vide: Viagem e missão no Congo. Academia das Ciências de Lisboa, MS Vermelho 296, Rafael de Castello de Vide, 73.

Instituto Histórioco Geogáfico Brasileiro (IHGB), Lata 6, documento 2, Catallogo dos Reis do Congo. 
Lacerda, P. M. P. Notícia da Companha e Paiz de Mosul, que conquistou o sargento mor Paulo Martins de Pinheiro Lacerda, no anno de 1790, até o princípio de 1791. Annaes da Associação Marítima e Colonial, sexta série. Lisboa, Imprensa nacional, 1846, p. 127-133.

Necessidades, Francisco. Factos memoraveis da História de Angola. Boletim Official do Governo Geral da Provincia de Angola no. 642. 16 Janeiro1858, p. 3.

Toso, Carlos: Relazioni inedite di P.Cherubono Cassinis da Savona sul Regno del Congo e sue Missioni. Im L'Italia Francescana, Roma. 1975, p. 135-214. 